Elena Furlanetto

\title{
Towards Turkish \\ American Literature
}

Narratives of Multiculturalism in Post-Imperial Turkey

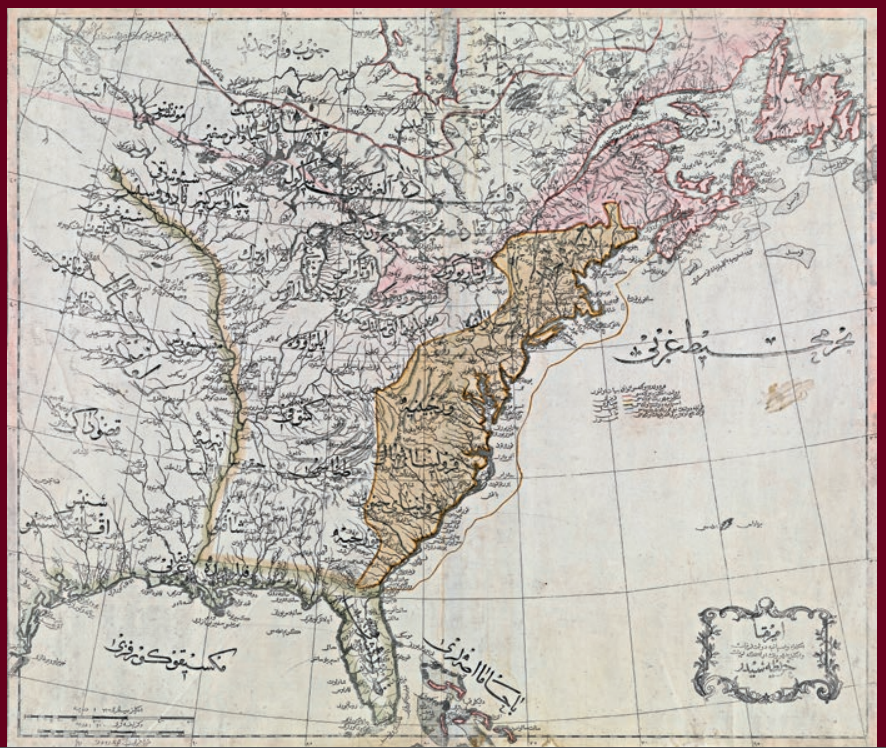




\section{Elena Furlanetto}

\section{Towards Turkish American Literature}

The author expands the definition of Turkish American literature beyond fiction written by Americans of Turkish descent to incorporate texts that literally 'commute' between two national spheres. This segment of Turkish American literature transcends established paradigms of immigrant life-writing, as it includes works by Turkish authors who do not qualify as American permanent residents and were not born in the United States by Turkish parents (such as Elif Shafak and Halide Edip). It also includes novels in which the Turkish and Ottoman matter decisively prevails over the American (Güneli Gün's On the Road to Baghdad and Alev Lytle Croutier's Seven Houses).
The Author
Elena Furlanetto received her MA in Eng- lish, American, and Postcolonial Studies from the Ca' Foscari University of Venice and her PhD in American Studies from the Technical University of Dortmund. She works as a researcher and lecturer at the University of Duisburg-Essen. 
Towards Turkish American Literature 


\title{
INTERAMERICANA \\ INTER-AMERICAN LITERARY HISTORY AND CULTURE HISTORIA LITERARIA INTERAMERICANA Y SUS CONTEXTOS CULTURALES HISTOIRE LITTERAIRE ET CULTURE INTERAMERICAINES
}

\author{
Editors: \\ Marietta Messmer (University of Groningen / editor-in-chief), \\ Barbara Buchenau (University of Duisburg-Essen), \\ Michael Drexler (Bucknell University), \\ Graciela Martínez-Zalce Sánchez (Univ. Nacional Autónoma de México) \\ and Gabriele Pisarz-Ramirez (University of Leipzig)
}

Reviewers and Advisors:

Ralph Bauer (University of Maryland), Robert Dion (University of Québec at Montreal), Yolanda Minerva Campos García (Universidad de Guadalajara), Manfred Engelbert (University of California at Los Angeles), Earl Fitz (Vanderbilt University at Nashville), Carole Gerson (Simon Fraser University at Burnaby/B.C.), Daniel Göske (University of Kassel), Markus Heide (Uppsala University), Djelal Kadir (Pennsylvania State University), Efraín Kristal (University of California at Los Angeles), Kurt Mueller-Vollmer (Stanford

University), Carla Mulford (Pennsylvania State University), Denis St. Jacques (Laval University at Québec) and Jeanette den Toonder (University of Groningen)

\section{VOLUME 10}

Notes on the quality assurance and peer review of this publication:

Prior to publication, the quality of the works published in this series is reviewed by external referees appointed by the editorship. 
Elena Furlanetto

\section{Towards Turkish American Literature}

Narratives of Multiculturalism in Post-Imperial Turkey 


\section{Bibliographic Information published by the Deutsche Nationalbibliothek}

The Deutsche Nationalbibliothek lists this publication in the Deutsche Nationalbibliografie; detailed bibliographic data is available in the internet at http://dnb.d-nb.de.

Zugl.: Dortmund, Techn. Univ., Diss., 2015

\section{Library of Congress Cataloging-in-Publication Data}

Names: Furlanetto, Elena, author.

Title: Towards Turkish American literature : narratives of multiculturalism in post-imperial Turkey / Elena Furlanetto.

Description: Frankfurt am Main ; New York : Peter Lang, 2017. | Series: Interamerican ; Vol. 10 | Includes bibliographical references. Identifiers: LCCN 2016056957 | ISBN 9783631677247

Subjects: LCSH: Turkish literature-American influences. |Turkish literature-History and criticism. | Multiculturalism in literature. | Postcolonialism in literature. | Sufism in literature. | Turks in literature.|Turkish-Americans.

Classification: LCC PL205 .F87 2017 | DDC 894/.3509—dc23 LC record available at https://lccn.loc.gov/2016056957

Cover image: Courtesy of the Osher Map Library, University of Southern Maine

The electronic version of this book is freely available due to funding by OGeSoMo, a BMBF-project to support and analyse open access book publications in the humanities and social sciences (BMBF: Federal Ministry of Education and Research).

The project is led by the University Library of Duisburg-Essen.

For more information see https://www.uni-due.de/ogesomo.

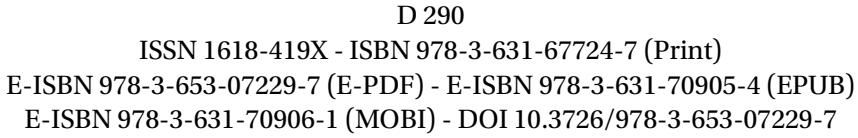

D 290

ISSN 1618-419X - ISBN 978-3-631-67724-7 (Print)

E-ISBN 978-3-653-07229-7 (E-PDF) - E-ISBN 978-3-631-70905-4 (EPUB)

E-ISBN 978-3-631-70906-1 (MOBI) - DOI 10.3726/978-3-653-07229-7
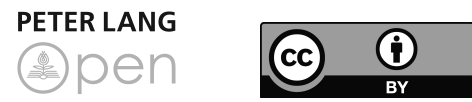

Open Access: This work is licensed under a Creative Commons

Attribution 4.0 unported license. To view a copy of this license, visit https://creativecommons.org/licenses/by/4.0/

(c) Elena Furlanetto, 2017

Peter Lang GmbH

Internationaler Verlag der Wissenschaften

Peter Lang - Berlin · Bern · Bruxelles · New York · Oxford · Warszawa · Wien This publication has been peer reviewed.

www.peterlang.com 
To my parents.

Who lifted me up so that I could play with the stars. 



\section{Table of Contents}

I. Introduction: What is (not) Turkish American Literature .......11

The Significance of the United States in Turkish American Literature.....21

Turkish American Literature and the "Transnational Turn".........................28

A Gentle Empire........................................................................................ 28

'Unearthing' and Embracing the Colonial Past .......................................... 33

Beyond Empire: A Postcolonial Reading of Turkish

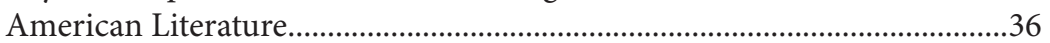

The Postcoloniality of Turkey ...................................................................... 38

Turkish American Literature and the Postcolonial Imagery ................... 40

Postcolonialism and Resistance: A Critical Perspective on

Turkish American Literature .................................................................... 45

II. Imaginary Spaces: Representations of Istanbul between Topography and Imagination ........................................................49

The Unplaceability of Orhan Pamuk ........................................................... 51

Orhan Pamuk: Overground and Underground Istanbul .......................... 59

"Safe Spaces of the Like-Minded": Elif Shafak's Cafés................................ 63

Becoming Someone Else: Imitation and Truthfulness .............................. 65

'Authenticity' and Americanization ........................................................... 70

Integration and Segregation: Shall the Twain Meet? ................................ 76

The Ottoman Utopia........................................................................................

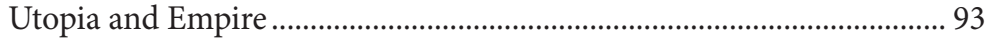

Ottoman Utopia and Neo-Ottomanism..................................................... 97

"Hrant Dink's Dream" ............................................................................... 100

Life in the Islands and in the Villages ..................................................... 103

Two Approaches to Cultural Identity ………………………………........ 110 
Between Imperialism and "Wholesome Curiosity":

Halide Edip’s Benevolent America.............................................................. 116

Imperialism and Humanitarianism ......................................................... 120

True Christians and very Unchristian Christians: American

Humanitarianism in the Empire Territories ........................................... 122

An Imaginary Us and an Imaginary Them ............................................. 126

Ferries and Orphanages: Rewriting the Legacy of Edip's Memoirs.......... 130

Hullabaloo on the Bosphorus Ferry: The Development of

Othering Strategies from "Borrowed Colonialism" to Nationalism..... 131

Ferries Rewritten: Elif Shafak's "Life in the Islands"............................... 137

Little Stories of Independence: Orphanages ............................................... 139

Towards Ottoman Sisterhood............................................................... 143

Women and Children First: Founding a 'Subaltern' Religion ...................... 146

Halide Edip: Rethinking Prophets and Fathers of the Nation............... 147

Sufi Madonna with Child ........................................................................... 150

Undermining Myths of Masculinity and the "Threat of Islam":

Ali’s Religion of Love ................................................................................ 152

A Religion of Love and a Religion of Fear: Mitigating the

East/West Divide in the Aftermath of 9/11 .............................................. 155

\section{Sufism in America and Turkey: A Transnational Dialogue ......161}

The American Journey as Sufi Journey: Emerson and Shafak.................... 162

Two directions in the American Discourse on Sufism:

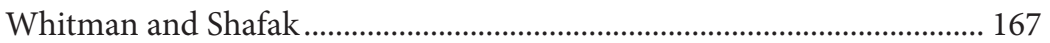

The Transcendental Author: from National to

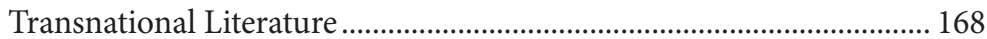

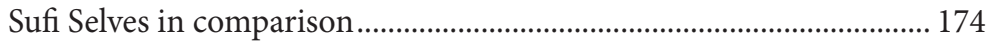

The Forty Rules of Love: A Secular Awakening ....................................... 178

Of Material Love and Ornamental Sufism................................................ 181

The Road to Baghdad Leads Somewhere: the (Ir)relevance of Sufism in Güneli Gün's On The Road to Baghdad ....................................... 182 
Secularized Sufi elements in On the Road to Baghdad.

Sufi Mysticism and North American Postmodernism:

Barth, Barthes, Gün

V. Ottoman Nature: Natural Imagery, Gardens, Wells, and Cultural Memory in Republican Turkey ............................... 199

American Nature and Turkish American Natural Symbolism.............. 201

Fig Trees and Pomegranates: The Shaping of Post-Genocidal Armenian Identity in Elif Shafak's The Bastard of Istanbul ........................ 203

Fig Trees: Beyond Negative Identities.................................................... 203

Pomegranates: Under two Empires........................................................... 207

Birds of Migration: Ornithological Symbolism in The Bastard of Istanbul and The Saint of Incipient Insanities ................................................ 214

Amnesiac and Memory-Bound Societies: The Bastard of Istanbul...... 214 The End of the Ottoman Garden: Alev Lytle Croutier's

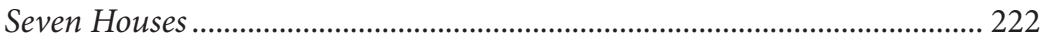

Space and Narrative in Seven Houses.................................................... 222

The Patriarch's Garden.............................................................................. 224

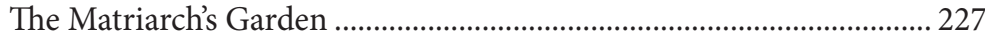

Re-Orientalism, Hyper-Orientalism, and Acceptance:

Problematizing Gardens in Seven Houses ....................................................... 234

Wells and National Amnesia: Orhan Pamuk's The Black Book.................. 242

Troubled Gardens of Turkey and the World ....................................... 253

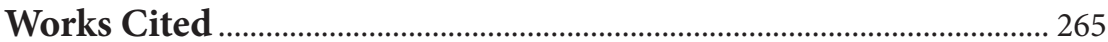

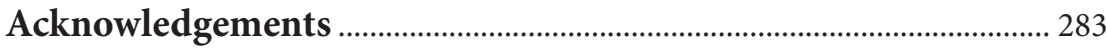





\section{Introduction: What is (not) Turkish American Literature}

In a 2005 interview with Khatchig Mouradian, Turkish American sociologist Fatma Müge Göçek laments the lack of dialogue between Turks and Armenians, exposing what she sees as the Turkish state's tendency to construct historiography in a way that suits a nationalistic agenda. Göçek begins and ends the interview on a hopeful note, claiming to have seen the signs of a postnational turn in Turkish cultural discourse and self-representation. For her, literature plays a crucial role in the articulation of more inclusive historiographical practices. Göçek praises Orhan Pamuk and Elif Shafak as the authors who are most invested in capturing the full "spectrum of meaning in [Turkish] society" and who highlight "the multi-ethnic, multi-cultural fabric of Turkish society, past and present" (Göçek in Mouradian 12). The publication of Shafak's first novel in English, The Saint of Incipient Insanities, in 2004 and Orhan Pamuk's Nobel Prize for literature in 2006 indeed projected Turkish literature beyond the national borders and sanctioned its presence in world literature. ${ }^{1}$

A series of cosmopolitan, binational writers of Turkish origin with strong biographical and literary ties to the United States have become prominent over the last decades. In their writings, they engage with the national horizon of Turkish literature but also explore the relationship between Turkey and America, turning to the U.S. as to an omnipresent interlocutor. I term this group of writers and their work "Turkish American literature." The term has been used in the past, but mostly in reference to the status, work, and biography of individual writers and never with the aim of delineating a literary phenomenon open to canonization and theorization. ${ }^{2}$ I understand Turkish American literature as defined by the

1 On the concept of "world literature" see Franco Moretti's "Conjectures on World Literature" (2000) and David Damrosch's What Is World Literature (2003).

2 See for example Gönül Pultar’s “Ethnic Fatigue: Başçıllar’s Poetry as a Metaphor for the Other 'Other Literature”' (1998) and “Güneli Gün's On the Road to Baghdad: Travelling Biculturalism” (2005); for a sociological study on the making of Turkish American identity in the United States, see Alice Leri's Who is Turkish American?: Investigating Contemporary Discourses on Turkish Americanness (2014). Historical studies on Turkish communities in the U.S. include the volume edited by Kemal Karpat and Deniz Balğamiş Turkish Migration to the United States (2008) and the work of Ilhan Kaya, such as Shifting Turkish American Identity Formations in the United States (2003), 
effort to question, revise, or dismantle the monocultural narratives of Kemalism, open a bicultural dialogue with the United States, and propose a multicultural identitarian model for Turkey that is strongly reminiscent of paradigms of American multiculturalism. The Kemalist model established itself as the country's leading ideology in 1923, with the birth of the Republic of Turkey under the leadership of its first president, Mustafa Kemal Atatürk. Kemalism places a strong emphasis on secularism, the separation of state and religion, radical Westernization, and an idea of Turkish identity primarily based on ethnicity. The Kemalist reforms, determined to eradicate the Ottoman heritage from the country's collective self, included the banishing of Islam from school curricula, the closing of Sufi schools and religious centers, the introduction of the Latin alphabet, the expulsion of Arab and Persian terms from the Turkish language, and the forced assimilation of non-Turkish ethnicities as 'Turks' (Çandar 89).

In my definition, Turkish American literature strives to overcome the discourses of Kemalism and seeks to redefine Turkey as a diverse, multicultural space. Albeit critical of Americanization as an outcome of Kemal's radical Westernization, these texts are informed by U.S. practices of multiculturalism and postmodernism. ${ }^{3}$ In fact, they challenge the nationalist doctrine of Kemalism by resorting to aesthetics of polyvocality, polyvalence, and multilingualism, and by focusing on borderland sensitivities and hybridity politics. This translates into a strongly bicultural literature, "nor Turkish, nor American, yet both" (Pultar, "Travelling Biculturalism" 49), whose uniqueness deserves to be studied and discussed as it offers fundamental insights into Turkish culture in its global and transnational declensions. In fact, Turkish American literature as I am discussing it here fits imperfectly in Turkey's national literary scene and, in contrast to migrant writing produced by larger migrant communities (such as Greek

“Turkish-American Immigration History and Identity Formations" (2004), and "Identity and Space: The Case of Turkish Americans" (2005).

3 In Multiculturalism and the American Self(2000) Boelhower and Hornung define multicultural policies in the U.S. as a series of attempts "to advance models for the creation of a society in which the different cultures would coexist on the basis of shared human values" (vii). The editors of the volume refer to Horace Kallen's enthusiastic description of cultural pluralism as "a mosaic of people, [...] a multiplicity in a unity, an orchestration of mankind" (Kallen in Boelhower and Hornung vii). The quotation is useful to underscore the centrality of metaphors in Boelhower and Hornung's concept of multiculturalism, including the melting pot, the mosaic, and the salad bowl. The evolution of these metaphors is connoted by a desire to define multiculturalism in America as a model that "involves not the elimination of differences, but the perfection and conservation of differences" (Kallen in Boelhower and Hornung viii). 
American or Armenian American literature), it cannot be defined through models of migrant literature in English. ${ }^{4}$

Another salient theme Turkish American literature engages with is the contested legacy of the Ottoman Empire. If in the immediate aftermath of the 2016 military coup d'état in Turkey the AKP's neo-Ottomanism has come to signify the seemingly irreversible rise of political Islam, religious radicalization, and authoritarianism, up to the early 2000s Turkish American literature strongly invoked a revival of Turkey's Islamic identity and looked at the legacy of the Ottoman Empire as the key to unlock a cosmopolitan future for the country. Turkish American texts present the empire's diversity as irrefutable proof of the nation's intrinsic potential for multiculturalism and tolerance of diversity. Ottoman history covers roughly six centuries and it is necessarily composed of very heterogeneous phases. Discourses of multiculturalism and multi-ethnicity whether historical or romanticized - refer to the 'classical age' of the Ottoman Empire (1300-1600), when the Ottoman rulers showed great openness towards ethnic/religious minorities, accepting their presence as part of the empire, allowing them to practice their faith, and integrating them in Ottoman identitarian narratives. ${ }^{5}$ Béatrice Hendrich writes that "the Ottoman rulers were interested in the functioning of state affairs, not in creating a 'Muslim state," or in putting an

4 Studies on migrant literature in America include Werner Sollors's Multilingual America: Transnationalism, Ethnicity, and the Languages of American literature (1998), Rebecca Walkowitz's Immigrant fictions: Contemporary Literature in an Age of Globalization (2010), Rachel Lee's The Americas of Asian American Literature (1999), and Carol Fadda-Conrey's Contemporary Arab-American Literature: Transnational Reconfigurations of Citizenship and Belonging (2014).

5 The late Ottoman Empire (1700 to 1923), by contrast, did not prove to be a model of tolerance. Quite to the contrary, it "took a hostile stance toward its own ethnic and religious minorities” (Konuk, East West Mimesis 4). Kader Konuk considers the unsuccessful siege of Vienna (1683) as a turning point that activated the Westernization mechanism. Westernization reforms extend throughout the $18^{\text {th }}$ and $19^{\text {th }}$ centuries, culminating in the Tanzimat era, which witnessed a "fundamental reorganization of Ottoman society" on the administrative and cultural levels (Konuk 7). In his article "They Live in a State of Nomadism and Savagery," Selim Deringil argues that, in the $19^{\text {th }}$ century, the Ottoman Empire had relinquished its notorious system of tolerance and "began imitating the Western colonial empires" (Diringil 312). This implied a consolidation of the imperial center and a marginalization of the provinces, which were Othered according to the Othering criteria of Western empires (ibid). Ussama Makdisi concurs in locating a "paradigm shift" in the $19^{\text {th }}$ century which transformed discourses of hybridity lying at the basis of Ottoman self-representation and state regulation into "an imperial view suffused with nationalist modernization rooted in a discourse of 
end to religious diversity in the empire (Hendrich 16-17). This attitude of laissez faire and pragmatism limited the rulers' interference in the organization of nonMuslim communities, and facilitated the relatively unproblematic coexistence of different ethnic and religious groups (Armenians, Jews, Kurds, and Greeks, among others), as the majority of these were allowed the right to practice their religion and maintain their identity. However, Turkish American literature tends to indulge in romanticized representations of the Ottoman Empire, exaggerating its tolerant and diverse character - a behavior that borders on imperial nostalgia ${ }^{6}$ and presents complications worth investigating.

Scholarship about Turkish American literature is scanty, which is probably attributable to the contested quality of the term "Turkish American."7 Before the early 2000s, configurations that mixed Turkish and Western literary forms were regarded with skepticism by Turkish scholars and critics, who were cautious in validating a hybridization between the Turkish and the Western selves. Ahmet Evin's assessment of the early Turkish novel dismissed the hybridization of Western forms with local contents. To Evin, the unity of a novel would necessarily be blemished by "the incompatibility of [Eastern and Western] themes," as abysmal structural defects would ensue from the unbridgeable distance between Turkish and European "methodologies and concerns" (Evin in Moretti 62). Jale Parla's analysis of Turkish fiction in the late $19^{\text {th }}$ century - a century that had been marked by intensive Westernization reforms - develops along similar lines. For Parla, late Ottoman literature reflected the inevitable "crack" provoked by "different epistemologies that rested on irreconcilable axioms" (Parla in Moretti 62).

progress" (Makdisi 769). The Armenian genocide in 1915 was the tragic climax of a change of perspective that had begun decades earlier.

6 Ottoman nostalgia is a discourse that glorifies "the imperial age and its cosmopolitanism, contrasting it with the parochialism and exclusionist ideology of the nation state" (Bechev and Nikolaïdis 82).

7 Attempts to address Turkish American literature thus far have defined the 'Turkish American' in strictly sociological terms. Numerous studies (e.g. the work of Frank Ahmed, Kemal Karpat, and, more recently, Ilhan Kaya and Alice Leri) have focused on Turkish American communities in the United States, and investigated the implications and meaning of the Turkish American condition. Yet, perhaps due to the limited literary output of these first- and second-generation migrant communities, little attention has been given to the 'Turkish American' as a literary category. The studies carried out by Gönül Pultar and Kader Konuk have certainly constituted the most prominent and visible sources on this topic thus far. Hopefully the forthcoming volume edited by Verena Laschinger by the title Turkish-American Literature (2016) will mark a step forward towards a more substantial outlining of the field. 
In her 1998 article "Ethnic Fatigue: Başçllar's Poetry as a Metaphor for the Other 'Other Literature,' Gönül Pultar invites us to problematize the concept of Turkish American literature. Pultar begins by stating that the number of Turkish immigrants in the United States is small and the members of the Turkish American community who are active in the literary arena are very few. On the one hand, works in Turkish by Turkish American writers do not concern themselves with the American mainstream or multicultural America, nor do they refer to the experience of the Turkish individual on American soil (Pultar 125). The few novels that are written in English "adopt the attitude of the consensual American" (Pultar 126). In Pultar's analysis, Turkish American literature is either too Turkish to be American, or too American to be Turkish.

Turkish American individuals seem to be caught in the paradoxically unproductive situation of not being discriminated against enough - at least specifically as Turkish Americans - to resort to literature to assert their ethnic identity. Yet, they remain isolated from the "predominantly different" American society that is supposedly "too positioned in the ontological space of the Other" to allow productive contaminations (Pultar 124). The problem highlighted by Pultar is that the Turkish and the American spheres hardly ever intersect. For this reason, the "putative juncture" (126) between these two selves, sparking the possibility of an ethnic Turkish literature in English, appears elusive.

In his study of world literature, Franco Moretti notes that everywhere the modern novel arises "as a compromise between West European patterns and local reality," and notes that the historical forces that regulated the relationships between the West and the "local reality" kept changing, and so did the result of their interaction (Moretti 64). Hence, if Turkish American literature was an unthinkable phenomenon in past decades, this does not mean that it must remain forever unthinkable. My contention is that Turkish American literature - defined as a corpus of texts written in English that establish a compelling bicultural connection with the United States - not only exists, but needs to be addressed as a significant expression of world literature. Although Turkish American literature began to catch the public's eye in the early 2000s, thanks to the visibility gained by Elif Shafak in the Anglophone market, it can be retrospectively extended to works produced in the $20^{\text {th }}$ century.

Writers who could be part of such a canon of Turkish American literature according to my definition incude Halide Edip, Selma Ekrem, Shirin Devrim, Güneli Gün, Alev Lytle Croutier, Judy Light Ayyildiz, Elif Shafak, Elif Batuman, and Serdar Özkan. In this study, I will focus on a core group of writers who have adopted English as their literary language and extensively engage with issues of 
ethnicity, identity, and dual citizenship. These are Halide Edip, Güneli Gün, Alev Lytle Croutier, and Elif Shafak.

Halide Edip (1884-1964) was a prominent scholar, author, political activist, and one of Turkey's first and most vocal feminists; she is remembered as a "figure of controversy in modern Turkish history" (Göknar, Orhan Pamuk, Secularism and Blasphemy 150). She fought in Atatürk's army in the War of Independence, earning the nickname of "Corporal Halide." Once one of Kemal's closest collaborators, Edip subsequently lost the favor of the Turkish leader, who branded her a traitor and publicly maligned her as the woman who "wanted an American mandate" over Turkey (ibid.). She and her husband chose self-exile in England and France. Edip travelled extensively, also to the United States, where she delivered lectures and public talks. Her literary production in English strives to present Turkish history and culture to European and American readers. She returned to Turkey in 1939 to embark on a political and academic career in her homeland. The autobiographical and non-fictional works she originally wrote and published in English in the 1920s and 1930s (Memoirs of Halide Edip in 1926, The Turkish Ordeal in 1928, and Turkey Faces West in 1930) were not translated into Turkish until the 1960s, when her status as a scholar and a patriot was re-evaluated.

Güneli Gün was born in Turkey in 1939. She is the author of Book of Trances: A Novel of Magic Recitals (1979) and On the Road to Baghdad (1994). Based in Ohio, she taught creative writing and women's studies at Oberlin College. She became known as Orhan Pamuk's translator, as she authored the first English translations of The New Life (Yeni Hayat, 1994; tr. 1998) and The Black Book (Kara Kitap, 1990; tr. 1995). In 2006, Maureen Freely revised and re-published both translations. Gün's writing incorporates elements of magical realism and North American postmodernism, and draws inspiration from Ottoman folklore and the One Thousand and One Nights. Her literary production, especially On the Road to Baghdad, is marked by the influence of the American postmodern author John Barth, who claimed to have "served as a midwife in [Gün's] delivery upon our writing scene" (Kadir 63).

Born in Izmir, Alev Lytle Croutier moved to the U.S. when she was 18. She studied comparative literature in Oberlin, Ohio. Eventually she moved to San Francisco where she founded a publishing firm called Mercury House. She is the author of two novels (The Palace of Tears, 2000, and Seven Houses, 2002), non-fictional works (Harem: The World behind the Veil, 1989, and Taking the Waters, 1992) and numerous articles and contributions to anthologies. In her interviews and non-fictional works, Croutier frequently reported being the granddaughter of a harem lady. This sapient self-exoticization allowed her to 
offer her American readership a supposedly first-hand account of one of the most secret spaces of Turkish culture, the harem, presenting herself as a unique mediator between cultures.

Elif Shafak is the author of numerous novels both in Turkish and English. Her most widely read works in Turkish include Pinhan (1997), Mahrem (The Gaze), and Bit Palas (The Flea Palace, translated by Fatma Muge Göçek). Her first novel in English, The Saint of Incipient Insanities, was published in 2004, followed by The Bastard of Istanbul in 2007, The Forty Rules of Love in 2010, Black Milk in 2012, Honour in 2013, and The Architect's Apprentice in 2014. ${ }^{8}$ Shafak often describes her life and work as being infused with cosmopolitanism and multiculturalism. Throughout her childhood, Shafak followed the highly mobile life of her diplomat mother. She was born in Strasbourg and spent her teenage years in Madrid, completed her studies in political science, international relations, and women's studies in Turkey and the Unites States, and worked at the University of Michigan and the University of Arizona. The recurrent concerns in her writing are the promotion of a cosmopolitan sensitivity for both Turkey and America, the condition of women, Islamic mysticism, and the retrieval of the Turkish Ottoman heritage. Shafak undoubtedly stands out as the most popular and globally acclaimed author analyzed in this study.

The work of these writers is particularly interesting in so far as it extends the label of Turkish American literature beyond the sphere of immigrant life-writing to literary works in English that do not produce immigrant success stories or what is commonly understood as migrant fiction, namely, fiction that relates the experience of first- or second-generation migrants struggling to balance two cultural traditions in U.S. territory. Literary works by Edip, Gün, Croutier, and Shafak present predominantly Turkish settings and characters, but are at the same time written for an American market and an American audience. Besides, most of these authors' biographies do not qualify for full inclusion into what is commonly understood as 'ethnic' or 'migrant' American literature, which demonstrates the necessity to address a Turkish American literature that is not the product of Turkish American biographies. Edip travelled to the United States frequently, lectured at American universities, and entrusted her work to American publishers, but never failed to return to Istanbul, which remained her place of residence. The same is true for Shafak, who lived in Boston, Michigan, and

8 This volume addresses novels by Shafak in which the United States features prominently, but it might have lost its relevance as a theme in her most recent novels. The question whether it still plays a role in her writing remains open. 
Arizona for years, but eventually returned to Istanbul. Only Gün and Croutier moved to the United States in their formative years.

If the biographies of these authors are too strongly rooted in the country of origin and thus do not fit the notion of 'Turkish American', their work does. "Literary classification," Rebecca Walkowitz claims in her essay "The Location of Literature," "might depend more on a book's future than on a writer's past" (23). "Migrant literature," Walkowitz reminds us, "is not written by migrants alone" (ibid.). Designed for and distributed on the North American literary market as well as the Turkish one, works such as Shafak's The Bastard of Istanbul and The Forty Rules of Love, Croutier's Seven Houses, Gün's On The Road to Baghdad, and Edip's autobiographical volumes function, in this sense, in more than one national context. The way in which these novels reimagine their home country as a global and transnational space, target the American readership, and use English as a literary language allows them to develop beyond Turkish borders and across two national dimensions. Pultar's 1998 study underlines the difficulties presented by the canonization of these texts in either cultural tradition. My analysis hopes to move beyond this point, acknowledging the impossibility of affiliating these texts with a single cultural tradition. My solution is to envision Turkish American texts as travelling texts that escape affiliation with one cultural context, and therefore cannot be claimed as either 'Turkish' or 'American.' At the same time, these texts turn their lack of solid affiliation into a productive tool to read one cultural context through the lens of the other.

A useful conceptual framework that allows for a theorization of Turkish American literature, in so far as it does justice to the 'travelling' quality of these texts, is cultural mobility. The model was introduced in the social sciences in the early 2000s by sociologist John Urry and later found its way into literary studies thanks to the work of Stephen Greenblatt and others in the seminal volume Cultural Mobility: A Manifesto (2009). The cultural mobility model helps to explain the movement of texts as well as people, suggesting that the two are related. Greenblatt and his co-authors claim that an understanding of a text's mobile nature and transnational character presupposes an understanding of physical movements. Mobility is a necessary component of literatures that are undergoing a post- or transnationalization and, as Rüdiger Kunow affirms, "perhaps the prototypical experience of our time" and of "the current 'post-national constellation" (Kunow 245), characterized by what Habermas called 'disenclavement' of society, culture, and the economy" (Habermas 48). On a similar note, Reinhard Meyer Kalkus (one of the contributors to Cultural Mobility: A Manifesto) questions the viability of the national literature model for those writers who "compose their 
works in one of the great languages of global intercourse (e.g. English, French, Spanish, or Arabic)" and who "not only live between cultures but address readers outside their own lands or origin" (Meyer Kalkus 96-97). Since the texts I analyze in this study are written and published in English and address audiences located abroad, I build on Kalkus's argument to stress that Turkish American literature reaches beyond the borders of Turkish 'national' literature ${ }^{9}$ and should not be labeled as such. Cultures, Greenblatt claims, are not generally understood as mobile and fluid but, quite to the contrary, as local and fixed. In fact, Greenblatt envisions cultures as entities whose power lies in the "ability to hide the mobility that is [their] enabling condition" (Greenblatt 252). This statement seems to apply to the Kemalist policies of erasure of the Ottoman legacy. By way of contrast, cosmopolitanism, a condition Turkish American literature aspires to, appears as a "utopian vision of mobility" (Greenblatt 18). Cultural mobility theories also help framing Turkish American authors not as migrants, but as a cosmopolitan elite of "frequent travelers, easily entering and exiting polities and social relations around the world, armed with visa-friendly passports and credit cards" (Calhoun 873), who imagine and write the world from a vantage point that is not necessarily accessible to the "working or low-income transnational class" (Binnie 9).

Besides being the product of authors with highly mobile, hardly nationalizable biographies, Turkish American literature presents and discusses a variety of spaces that can be read through the lens of cultural mobility theory. The gardens and courtyards analyzed in Chapter Four transform as Turkey re-orients itself from the East to the West. They reflect the country's passage from empire to republic, and undergo a reshaping due to the popularization of new cultural influences - Americanization in particular. The Ottoman utopia, in Chapter One, projects the empire as a space open to be traversed by diverse cultural artifacts and practices: the identity that results from this openness is necessarily one in constant flux. The Ottoman Empire itself, with its codes of Othering and belonging, is a mobile entity for Shafak, who, in The Bastard of Istanbul, resuscitates it on American territory in the form of an online community called "Café Constantinopolis." Its Istanbulite counterpart, "Café Kundera," instead, is a highly fluid

9 I am aware that 'Turkish literature' is, per se, a contested notion; yet, it is beyond the aim of this study to define what Turkish literature is. Erdağ Göknar uses the terms "Turkish literary field” (Göknar, "Secular Blasphemies” 305), “Turkish literary context” (302), and "Turkish literary modernity" (312) to express literary activity within the border of the Turkish nation. By Turkish literature, in opposition to Turkish American literature, I mean non-diasporic works of literature published in Turkey, in Turkish, by Turkish publishing houses. 
and unstable space whose walls are covered with photographs of far-away destinations customers can travel to with their imaginations - including the United States. The orphanages in Chapter Two witness the coming and going of children during the War of Independence, some of them forced to convert from Islam to Christianity or vice versa.

Theories of cultural mobility help us identifying the function of these spaces, which remind one of containers that showcase "moment[s] in the process of transnational mobility in which 'here' and 'there,' or 'them' and 'us', intersect and interact in processes of mediation and negotiation, adaptation/acculturation or rejection/expulsion" (Kunow 260). The most indicative locus of mobility in the Turkish American literature presented in this study is perhaps the iconic ferry crossing the Bosphorus, imagined in almost oppositional ways in Edip and Shafak (Chapter Two). Mobility theory would point at the ferry as an important textual element that showcases the connection between "different forms of travel, transport and communication" and "the multiple ways in which economic and social life is performed and organized through time and various spaces" (Urry 6). The limited space of the ferry magnifies the ongoing negotiation of social, (post) colonial, and ethnic conflicts in a historical moment of passage (end of the empire, rise of Atatürk's republic).

The chapters in this book negotiate Turkish American literature as a cohesive corpus of fictional texts that present reoccurring narratives, images, and literary practices. These narratives include the intense engagement with imperial nostalgia (in Chapter One), with the rewriting of history and religion from a matrifocal perspective (in Chapter Two), with the use of Sufism as a common ground between the American and Turkish cultures (in Chapter Three), and with botanic and natural imagery (in Chapter Four). To underscore the ubiquity and wide-range applicability of these narratives, the chapters in this volume address some of the most essential categories of literary analysis, from space (Chapter One), down to history and religion (Chapter Two and Three), and nature (Chapter Four). Ultimately, these narratives can be retrieved in both fictional and nonfictional works by authors of Turkish American literature. For this reason, my study will mostly focus on novels, but also take into account essays, autobiographies, and interviews with the authors, as these texts are also replete with signs of and references to the narratives mentioned above.

Turkish American narratives are ingrained in the Turkish political debate in so far as they express a strong rejection of Kemalist discourses and hope to articulate a more inclusive identity for the nation of Turkey. Turkish American literature appears, therefore, as highly political. In her perceptive interview, Göçek charges the 
Kemalists with severing the connection between the Turks and their own past, manipulating historiography, and controlling the circulation of knowledge. ${ }^{10}$ More inclusive identitarian narrations, according to Göçek, can be achieved by integrating the cultural elements that the Kemalists had banned from Turkish historiography to fulfill the dream of a modern, Westernized Turkey. The works I am referring to as Turkish American integrate into Turkey's postnational, multicultural self the legacy of the Ottoman Empire, the role of Islam as a pillar of Turkish collective consciousness, Islamic heterodox beliefs such as Sufism, and the silenced histories of marginalized groups such as former imperial minorities and women.

\section{The Significance of the United States in Turkish American Literature}

Since the centrality of the Turkish nation for authors of Turkish American literature is indubitable, one of my urgent questions regards the position of the United States and its cultural narratives within Turkish American literature and, vice versa, the relevance of Turkish American literature for American Studies. In her 2004 presidential address to the American Studies Association entitled "Crossroads of Cultures: The Transnational Turn in American Studies," Shelley Fisher Fishkin called for an opening of the field of American Studies that would bring representations of America produced outside the United States into view. To this day, Fishkin affirms, this project of de-centering and re-centering the focus of American Studies "remain[s] work in progress" (Fishkin 21). Fishkin invites American Studies scholars to understand "how the nation is seen from vantage points beyond its borders" (20); she also imagines that in the future scholars will make "more of an effort to seek out the view from el oltro lao [the other side]" (24). Here, Fishkin quotes Gloria Anzaldúa and therefore strongly addresses America's relationship with its own southern borderlands. But the scope of transnational American Studies as Fishkin imagines it expands beyond immediate borders to include "a broad array of cultural crossroads shaping the work of border-crossing authors $[\ldots]$ that straddle multiple regional and national traditions" (32). The Turkish American literature analyzed in this study is certainly an example of transnational literature that explores affinities and contact zones

10 "The position that emerges in Turkey," Göçek writes, "is unfortunately one based on the ignorance of our own past, partly because of the partial knowledge that exists out there in what passes as Turkish scholarship and also because, as a consequence of the alphabet reforms, people cannot read the original Ottoman texts themselves, and the translation of those Ottoman sources into Latin script has been controlled by the government as well” (Göçek 4). 
between the U.S. and Turkey, defining the U.S. as one of Turkey's most significant cultural interlocutors.

Fishkin also redraws the boundaries of ethnic fiction, whose current canons seem to contribute to North American ethnocentrism, in so far as their focus lies with "the proverbial immigrant who leaves somewhere called 'home' to make a new home in the United States" (24). American studies scholars, Fishkin suggests, should rather engage with other literary phenomena addressing diversity and the "endless process of comings and goings that create familial, cultural, linguistic, and economic ties across national borders" (ibid.). These processes, according to Fishkin, have been addressed by transnational American scholars who work with increasing interest on how U.S. culture abroad has helped "societies outside the United States negotiate aspects of their own cultures" (33). The study of this kind of interaction, for Fishkin, should not necessarily be framed and dismissed as cultural imperialism, which "turns out to be too simple a model to understand how culture works" (33), and she encourages to devise new models to make sense of the American presence abroad. Turkish American literature is connected to transnational mobility rather than migration, since some of the core authors of this study have returned to Turkey after having traveled to or lived in the United States. The frequent travelling that constitutes the foundation of Turkish American literature is reminiscent of Fisher Fishkin's "endless process of comings and goings" that reshaped the dynamics of migration and now calls for a revision of the parameters of ethnic fiction. These highly mobile biographies result in a literary production with a bicultural focus and a tendency to read Turkish cultural identity through the lens of their experience of America, focusing on the American presence - commercial or cultural - in the homeland. As much as Turkish American texts ponder how deeply U.S. presence has shaped identitarian discourses in Turkey, this is hardly ever dismissed as 'imperialism.'

On the one hand, Turkish American literature engages with the Ottoman and the Islamic traditions, on the other hand, it incorporates Western - and, more specifically, American - cultural narratives and spaces in the construction of Turkey's identity. The American element has a special significance in this web of references because, even in the era of globalization, Winfried Fluck affirms, the U.S. remains a paradigmatic, agenda-setting society. Thus, Fluck continues, "it is still a major issue for the rest of the world whether, how and to what extent it is subject to, or affected by, American power" (Fluck 73). The difference between Westernization and Americanization, for example, is of paramount importance in the Turkish context. Fluck defines the two phenomena in broad brush-strokes, arguing that Westernization is "the process by which secular values of Western 
societies such as the doctrine of individual rights, religious freedom, liberal democracy, or civil society become the inspiration for value change," while Americanization indicates "a process by which specific elements are adapted from American society and culture" (Fluck 31 ). Both processes are usually equated with modernity and modernization. Fluck adds that "the issue is not one of an 'either-or' choice, since the terms 'modernity,' 'modernization,' 'Westernization,' and 'Americanization' describe different aspects of cultural development in Western societies and have a different explanatory range" (31). Westernization and Americanization in Turkey are interconnected processes, but correspond to different periods and different understandings of modernity.

Westernization has a longer history that possibly dates back to the Ottoman Empire's unsuccessful siege of Vienna (1683), which, according to Kader Konuk's East West Mimesis, triggered the first Westernization reforms as a response (6). Successive waves of Westernization reforms followed that historical moment. The Tanzimat (1839-1876) appears as one of the most radical, as it programmed a fundamental restructuring of Ottoman society. Interestingly, Konuk refers to the Tanzimat as a "Francophile" age marked by an "appropriation of French culture" (7), which indicates that $19^{\text {th }}$-century Turkey adopted France as the flagship of modernity and progress. Turkey's Westernization reached its peak with Atatürk's republic, which "called on Turkish citizens to identify as Europeans, even while seeking political independence from Western European countries" (8). As this brief passage has pointed out, the late-Ottoman and Kemalist Westernization projects are for the greatest part, although not exclusively, an 'Europeanization' enterprise.

As Laurence Raw claims in his essay "'Communicating America,' Validating Turkey," Americanization can also be read in connection with the Kemalist project of modernization of the country, although not primarily (Raw 84, 87). Americanization in Turkey started in the 1950s, when the electoral victory of Adnan Menderes' Democratic Party in 1950 marked the end of the unchallenged rule of Kemalism. The fascination with America increased in the following years: in October 1957, President Celal Bayar declared that Turkey aspired to emulate the U.S. so that one day it could become a "prosperous and populous 'Little America" (Bayar in Mufti 1). The statement was adopted as a slogan by Bayar's Democratic Party. The Fifties were a crucial decade in Turkish-American relations: In 1947, Turkey was included in the Marshall Plan, sent 15,000 troops to Korea in 1950, and was admitted to NATO in 1952 - which, as Nuri Bilge Criss notes, many considered "an extension of the United States" (Criss 473). In addition, the U.S. was contributing generously to the improvement of Turkish agriculture, industry, 
and transportations (Bozdoğan 118). The Fifties marked the shift from Kemalist Westernization to Americanization: a phenomenon that was informed and facilitated by the long tradition of Westernization, but also modified its goals and ideals. During this time period, Sibel Bozdoğan notes, "the meaning of 'Western' shifted considerably, from 'European' to 'American"' (116). The prominence of the U.S. in Turkish foreign policy created a widespread enthusiasm for the values generally associated with America - i.e. "increased literacy, increased mobility, a new spirit of enterprise, the use of communication technologies, urbanization" among others (ibid.) - and encouraged Turkish citizens to emulate them, in the conviction that, Bozdoğan explains, they "would give way to new patterns of thought and behavior" (ibid.).

Several studies equate Americanization with modernization or modernity. Yet, in a Turkish context, it is necessary to differentiate between late-Ottoman/ Kemalist modernity, bound to the European experience, and the idea of modernity connected to Americanization from the 1950s on. On the one hand the modernization process enforced by Atatürk in the early $20^{\text {th }}$ century was rooted in the concept of secularism (in Turkish, laiklik), derived from the French ideal of laïcité, which determined the complete exclusion of religion from the affairs of the state. "Since the 1930," Cihan Tuğal confirms in "NATO's Islamists: Hegemony and Americanization in Turkey," the Turkish state favored "a more or less authoritarian exclusion of religion from the public sphere"; Kemalist "modernization," according to Tuğal, "constitute[d] categorical proof of the disestablishment of religion in Turkey" (7-8).

On the other hand, Americanization in the Fifties was still understood in the context of modernity and expected to bring about urbanization, the rise of commercial culture, and progress (Ferenbach and Poigner xiv), but it left a larger space for Islam in the public sphere. "America was perceived as the ideal democratic society by the followers of DP [Democratic Party]," Bozdoğan argues, "including religious and traditional Turks who admired the freedom of religious expression in America as an alternative to the much-resented radical secularism of the Kemalist revolution" (Bozdoğan 118). In addition to that, Americanization in Turkey had been influenced by debates and publications relative to "modernization theory." Two of its seminal texts addressed Turkey very closely: namely Bernard Lewis's The Emergence of Modern Turkey (1961) and Daniel Lerner's The Passing of Traditional Society: Modernizing the Middle East (1967). Although modernization theory enumerated religion among the factors that prevented the progress of a country and was therefore to be limited, Americanization in Turkey developed parallel to Islam's renewed public visibility. This implies that Turkey 
did not passively replicate American models, but adapted them to its current political situation and imaginary.

Fluck claims that there are two Americas, and two ensuing models of Americanization. One "has a distinctive economic and social structure"; the other, which he calls an "imaginary America of the mind," is a "deterritorialized space that is filled with a selection of objects of choice [...] a sheer endless reservoir of interesting cultural forms" (Fluck 28). The flow of cultural products, rather than the fascination for the U.S. as a geographical territory, is central to the understanding of Americanization in Turkey and the role it played in the shaping of its identity. In Transactions, Transgressions, Transformations, Heide Ferenbach and Uta Poiger reflect on how "images and products ranging from American movies and music to fashion and architecture, made by industries based in the United States $[\ldots]$ ha[ve], by offering alternative modes of identification, been crucial in the shaping of new identities" (Ferenbach and Poiger xiv-xv). It is this shifting, malleable "America of the mind" that the novels in this study principally address, and they investigate the possibilities in which the heritage of Americanization can be integrated in Turkish identity, tradition, literature, even language.

In my study, I examine the ways in which the U.S. served as an influential interlocutor capable of affecting and molding Turkish American literature's understanding of Turkish national identity. In Multiculturalism and the American Self, Boelhower and Hornung argue that European societies have followed the American example in shaping their own multicultural discourses. Thus, due to America's "special status as the number-one immigration country" and the "advanced" status of multiculturalism debates in North America, the U.S. multicultural model has become the leading one globally (Boelhower and Hornung viii). By the same token, Bechev and Nicholaïdis claim that the current discourse on multiculturalism in Turkey "stems from the particular experiences of various Western European and North American societies dealing with immigrant communities" (Bechev and Nicholaïdis 82). The case of Turkish American literature, where multiculturalism is understood as a conglomeration of Ottoman and American practices of multi-ethnic and multi-religious coexistence, certainly complicates the picture. The ubiquitous examples of cultural diversity that the United States presents facilitate the rediscovery and treasuring of Turkey's own multicultural past and potential in Turkish American texts, where the Ottoman multicultural model is frequently combined with American narratives.

The United States is frequently represented as the agent making Turkey's multicultural future possible and as a privileged neutral space where resilient imperial 
conflicts (e.g., between Armenians and Turks, or Greeks and Turks) can be renegotiated. Göçek's residence in the United States, for instance, profoundly changed her perception of her own country. Göçek reports that the elements that allowed her to 'see' the Armenian question in Turkey were American liberal education and its tradition of the freedom of the press. "[Before I came to the U.S.]," Göçek explains, "I myself wasn't aware of what happened, because there are no sources that I could have read and critically studied other than the ones that presented the Turkish State's version of history. This was, of course, very hard to overcome and I was able to do so because I came to the U.S. and continued my scholarship" (Göçek in Mouradian 3).

There is much to be gained from analyzing Turkish American literature as a phenomenon that develops independently from what is considered either as 'canonical' ethnic American or migrant literature. Pultar addresses this issue in her 2005 article "Güneli Gün's On the Road to Baghdad: Traveling Biculturalism," where she argues that the relationship between Gün's novel On the Road to Baghdad and the United States develops along bicultural or transnational lines. On the Road to Baghdad, Pultar writes, "is a bicultural novel, not purely American (ethnic or multiculturalist) fiction, not purely a Turkish novel" (49). Pultar also states that Gün's novel is not comparable to works by 'ethnic' or multicultural authors such as Amy Tan or Maxine Hong Kingston, in so far as migrant literature in America configures itself mostly as life-writing. This kind of fiction, for Pultar, contains "the renderings on paper of American experiences, [...] consisting of the engagement of American authors with their parents' non-American culture" (Pultar 48). Although U.S. narratives of multiculturalism remain center stage, the factor that grants Turkish American literature its detached and unique status is a seeming 'marginality' of the American element, in favor of an overwhelming preponderance of the effort to reconfigure Turkish identity as a transnational, hybrid, multicultural construct.

A comparison with the more widely researched field of Turkish German literature, for example, reveals many similarities but also one fundamental difference. In her article "Re-Thinking and Re-writing Heimat," grounding Turkish German literature in the social reality of migration, Heike Henderson refers to Turkish German women writers as migrant writers (Henderson 229), a category that encompasses first- and second-generation immigrants. In some ways, Henderson's theorization of Turkish German literature is applicable to Turkish American literature. For Henderson, Turkish German authors do not lament the loss of home but re-write a concept of home that opens up to the possibility of cosmopolitanism and multiculturalism (Henderson 226, 229, 239). Most 
notably, "they offer a concept of Heimat that allows for cultural differences and provides a chance to feel at home in a world of transnationalism and multiculturalism, thus challenging the racist concepts of exclusion or forced assimilation" (239).

Similarly, Turkish American literature decisively reacts against the Kemalist rupture with Turkey's imperial past, which triggered a comparable feeling of cultural loss, and advocates the articulation of more inclusive identitarian imaginations. However, the element that includes Turkish German literature into the canons of migrant literature and excludes Turkish American literature from the same category is precisely the concept of Heimat. For Turkish German authors, Henderson writes, "what is at stake [is] the political landscape of Germany, the question of whether Germans are willing to include minorities and migrants in their understanding of Heimat or not" (229). The quote sheds light on the fact that Turkish German literature places the emphasis on the country of destination, Germany, which also corresponds to Heimat, as "they all claim Germany as their home" (239). The agenda of Turkish American literature is at the same time identical and antipodal to that of Turkish German literature, as it reflects its concerns but directs them elsewhere. In Turkish American novels, in fact, the Heimat remains the country of origin, which is reimagined through the cultural narratives of the culture of destination, the United States.

The lack of an experience of permanent migration in the United States and the prevalence of Turkish settings and locations do not prevent authors of Turkish American literature from integrating American cultural narratives into the construction of a multicultural Heimat. Turkish American novels acknowledge the profound impact of Westernization and, specifically, Americanization on the young Republic of Turkey - two phenomena that had been encouraged by the Kemalists. Not only do Turkish American novels embrace the outcomes of Westernization in Turkey, they also try to reintegrate the linguistic, religious, political, and artistic heritage of the multicultural Ottoman Empire, targeted by the Kemalists as a period of obscurantism and barbarity and expunged from the nation's cultural memory. The Turkish identity Turkish American literature promotes is highly syncretic, revealing the history of the country as multilayered and composite, rather than as the product of a state-driven selection of acceptable mono-ethnic components. ${ }^{11}$ Turkish American literature (above all Shafak

11 This syncretic view of the country's identity separates Turkish American novels from other Turkish novels that have transcended the national borders to become world literature and negotiate all the different components of Turkish culture, such as the work of Orhan Pamuk. While Shafak's fiction is indebted to American frames of thought in 
and Croutier) tends to allow the cultural and material products of Americanization to shape Turkish identity without equating them to loss, but to enrichment and growth. For example, American and Turkish characters which come into contact with each other - or strive to combine the Turkish and American sides of their mixed identity - seem to achieve a beneficial degree of completeness or find relief from their insecurities regarding their own selves. In Croutier's Seven Houses, the idea of an Americanized Turkey is contemplated with curiosity and expectancy, and welcomed in so far as it leads to a more complex manifestation of Turkish culture. Ultimately, Turkish American literature differentiates itself from both Turkish migrant literature and Turkish literature, constituting an independent province of world literature which engages Turkey and the U.S. in an intense cultural dialogue. It is the aim of my study to reflect on this dialogue and, when possible, to facilitate it.

\section{Turkish American Literature and the "Transnational Turn"}

\section{A Gentle Empire}

The dominant polarity between constructions of empire and nation can provide fruitful insights into Turkish American politics and poetics. Turkish American literature rejects the narratives of Turkish nationalism, but at the same time, in a slightly contradictory fashion, it poses the problem of imperial nostalgia. ${ }^{12}$ The discourse of Ottoman nostalgia in Turkey, which became prominent with the rise of neo-Ottomanism and its revival of the country's imperial past, portrays the Ottoman Empire as an exceptionally benevolent one, unacquainted with the brutality of European imperialism. In a way that is reminiscent of

numerous ways, Orhan Pamuk's work - especially The Black Book (1990) and The New Life (1991) - regard the Americanization of Turkey as an indelible stain that brought the country to the ultimate loss of its identity or to the realization of the impossibility of having an identity. All manifestations of Turkish identity - whether pre-Ottoman, Ottoman, or Republican - dissolve under the overpowering Western presence. The Black Book and The New Life exude a sense of loss and abandon, which Ian Almond describes as "the sadness of one's selflessness [...] the melancholy of losing one's identity to someone or something else," namely, "to the economic and cultural centers of North America and Europe" (Almond 82).

12 On imperial nostalgia see Svetlana Boym's The Future of Nostalgia (2001) and Paul Gilroy's After Empire (2004) and Postcolonial Melancholia (2005). 
Frank Kelleter's concept of American non-imperial imperialism, ${ }^{13}$ recent debates ${ }^{14}$ about the Ottoman Empire have strived to define it as a non-empire, exempt from the norms and practices adopted by Western imperial powers. Most strikingly, Turkish American literature invites to look at Turkey's imperial experience to overcome nationalist frames of mind. Thus, Turkish American literature subscribes to the idea of a non-imperial Ottomanism, choosing to equate the transnational condition with the vision of the Ottoman Empire as a multicultural space and a gentle domination.

In her article "Constructing Turkish 'Exceptionalism': Discourses of Liminality and Hybridity in Post-Cold War Turkish Foreign Policy" (2011), Lerna Yanik makes abundant use of secondary sources on American Exceptionalism to describe and contextualize what she terms "Turkish Exceptionalism." It becomes evident that American Exceptionalism, more than any other national manifestation of Exceptionalism, remains the main object for comparison and confrontation in the definition of Turkish Exceptionalism. In its American expression, exceptionalism corresponds to "the idea that the development of American culture has taken place under conditions of its own [...], conditions that are different in constellation and degree from those of other countries" (Fluck 60). In a more critical register, exceptionalism may also overlap with the conviction of being exempt from the flaws that stain the history of European countries.

In the Turkish context, by way of definition, exceptionalist narratives find expression in both imperial and post-imperial Turkey. What defines 'Ottoman' exceptionalism is the myth of a gentle empire, whose ways and practices differ substantially from those of other imperial ventures. ${ }^{15}$ Scholarship about the

13 Kelleter defines American imperialism as "anti-imperial imperialism": "the desire to escape from European-style imperialism" and its "classical imperial aspirations" (Kelleter 31-32).

14 See, for example, Donna Landry, “The Ottoman Imaginary of Evliya Çelebi: From Postcolonial to Postimperial Rifts in Time" (2015).

15 "Unlike the case of the Spanish empire in the New World, which was predicated on the relentless conversion and Christianization of the entire indigenous population," Ussama Makdisi explains, "the Ottoman state sought to manipulate and regulate rather than to overcome the multi-religious nature of the empire (Makdisi 774). This lasted until the $19^{\text {th }}$ century, which "saw a fundamental shift from this earlier imperial paradigm into an imperial view suffused with nationalist modernization rooted in a discourse of progress" (769). The paradigm shift that overcame the Ottoman Empire in the $19^{\text {th }}$ century was characterized by the rise of a 'Turkish' rather than 'Ottoman' sensibility and by the diffusion of a form of Ottoman Orientalism based on the idea 
Ottoman Empire has been representing it as a tolerant system where diverse ethnic and religious groups could peacefully coexist and enjoy the possibility of acquiring wealth, power, and influence. ${ }^{16}$ Islam was the official imperial religion, but other creeds, such as Judaism and Christianity, were allowed to prosper. The Ottomans' tolerance for diversity earned them an 'exceptional' reputation in history, one that finds its most emblematic expression in Edward Said's statement to the Israeli newspaper Ha'aretz: "I hate to say it, but in a funny sort of way, it worked rather well under the Ottoman Empire, with its millet system. What they had then seems a lot more humane than what we have now" (Said, "My Right to Return" 447). Many other voices reinforce this perspective. Urban studies scholar Maurice Cerasi writes that "the Ottomans had not brought a pre-existing, therefore imposed, culture" (Cerasi 134), thus mitigating the disruptive force of the Ottoman imperial venture. Ottoman domination, Cerasi continues, introduced in the conquered territories a "novel" principle of cultural synthesis that gave "to all, even when in conflict, the sense of belonging to a common culture in daily life" (ibid.).

'Turkish' exceptionalism ${ }^{17}$ (not to be confused with 'Ottoman' exceptionalism) refers to the modern Turkish nation state primarily in two ways. First, Turkey's glorious imperial past would have granted the country an 'exceptional' status even after the demise of the empire; for this reason, the perspective of becoming the victims of colonization and foreign occupation was received with intense

of a primitive and barbaric East that could be redeemed by means of the Ottomans' mission civilisatrice. Even before the $19^{\text {th }}$ century, however, equating the Ottoman model with the contemporary understanding of multiculturalism amounts to a misreading and a romanticization of the Ottoman domination.

16 See Landry's "The Ottoman Imaginary of Evliya Çelebi: From Postcolonial to Postimperial Rifts in Time" (2015); Cerasi's "The Formation of Ottoman House Types: A Comparative Study in Interaction with Neighboring Cultures" (1998); and Mills's "Narratives in City Landscapes: Cultural Identity in Istanbul" (2005) and "The Place of Locality for Identity in the Nation: Minority Narratives of Cosmopolitan Istanbul" (2008).

17 For a more complete understanding of Turkish Exceptionalism see the work of Turkish political scientist Serif Mardin, especially "Turkish Islamic Exceptionalism Yesterday and Today" (2005). On the myth of Turkey as a 'model democracy' in the Middle East see Meliha Benli Altunisik's "The Turkish Model and Democratization in the Middle East" (2005). For the notion of Turkish 'negative' Exceptionalism, implying that foreign agents worked against Turkey because of its 'uniqueness,' see Lerna Yanık's “Turkish Exceptionalism and its Critics" (2014). 
shock and perceived as an outrageous paradox..$^{18}$ Second, due to processes of radical Westernization and the separation between state and religion enforced by the Kemalists, Turkey appears in the national and global imagination as an 'exceptional' Muslim democracy. Historian Bernard Lewis, for example, approvingly declared that, among Muslim countries, "Turkey alone has formally enacted the separation of religion and the state" (Lewis in Çandar 94, emphasis added).

The term 'Turkish exceptionalism' in its application to Turkey's post-imperial modernity appears in numerous studies, and views differ as to what it means. Gönül Pultar's and Donna Landry's definitions of Turkish exceptionalism are especially relevant to my study. Pultar addresses it as an epiphenomenon of Kemalism, while Landry includes it in the neo-Ottomanist paradigm. In "Ethnic Fatigue," Pultar claims that Turkish exceptionalism has been

"imagined" - whatever the historical facts may be - from 1923 onward by the founding fathers of the Republic, and drummed since, in Jacobean fashion, into every schoolchild of Kemalist Turkey. [...] [T] he acquisition of United States citizenship is usually a source not of pride but of shame among Turkish-Americans, who feel the need to explain it away apologetically as due to professional obligation. (Pultar 126)

In the excerpt, Pultar refers to the Kemalist understanding of Turkish exceptionalism, which celebrates Turkey's unique development from Eastern empire to Westward looking, modern republic. The subsequent Westernization waves in Turkey, which have contributed to the genesis of this kind of Turkish exceptionalism, explain Pultar's passing references to the French context ("Jacobean") and the American one ("founding fathers"). Pultar describes Turkish exceptionalism as a reason for anxiety for Turks in the U.S., as the sense of belonging to such 'exceptional' nation seems to discourage Turkish citizens from acquiring a second citizenship, and hence it is significantly cast as an obstacle to the transnational condition. Here Pultar claims that a sense of Turkish exceptionalism started to pervade public discourses in Turkey since 1923, but, as my argument has shown, imperial history before the foundation of the republic has been exceptionalized as well, although in a different way.

Donna Landry's definition differs from Pultar in so far as she does not consider Turkish exceptionalism as a byproduct of Kemalism, but of the more recent political and cultural ideology of neo-Ottomanism. She highlights the

18 "The vulnerable Ottoman polity, disgraced by the Armenian genocide, riven by ethnic violence and famine as well as militarily defeated, had become a state to which the European powers could dictate terms that would have been unthinkable in previous centuries" (Landry 136). 
connection with Turkey's imperial past and present colonial anxieties. Landry identifies "Turkey's sense of exceptionalism" as a post-Kemalist phenomenon and connects it to Turkey's "newly expressed desire to serve (once more) as a global player" (Landry 152). "The attempted abolition of the Ottoman past from official Republican history," Landry continues, "rendering it a perpetually lost object, encrypted and incapable of being mourned, has been producing some disturbing spectres on the Turkish political scene as well as some hopeful ones" (ibid.). In her article, Landry defines Turkish exceptionalism as twofold, bearing connections to both imperial nostalgia and imperial anxiety. On the one hand Turkish exceptionalism resides in the neo-Ottomanist desire to "exert more 'soft power' - political, economic, diplomatic, and cultural influence - in formerly Ottoman territories" (Taşpinar, "Three Strategic Visions" 2) and to emerge as a mediator between Western democracies and the Middle East. On the other hand, Landry's definition hints at the "spectres" left by the impossibility to mourn the loss of the Ottoman Empire. One of these would be the Sèvres syndrome (Landry 152): a phobia of foreign interference and violation of Turkish national sovereignty by European states, which Landry describes as "symptomatic of unresolved attachment despite Republican attempts at a rupture from the Ottoman past" (152). It owes its name to the Sèvres Treaty (1920), by which the Ottoman Empire was to be dismembered and parceled out to European states. ${ }^{19}$

Yanik's analysis of Turkish exceptionalism is particularly relevant for the purpose of this section as she highlights the connections between the neo-Ottomanist rhetoric of multiculturalism and a specific form of Turkish exceptionalism. Yanrk traces this kind of rhetoric back to the "Özal years," ${ }^{20}$ when Prime Minister Turgut Özal, remembered as one of the main ideologists of neo-Ottomanism, urged a re-evaluation of Turkey's Ottoman legacy and thus challenged the strictly anti-Ottoman discourses of Kemalism. “The Özal years,” Yantk argues, “were a milestone in the way Turkish history was hybridized to shape Turkish exceptionalism, as Turkish elites revised 'multiethnic' and 'multireligious' to mean 'multicultural”' (Yanık, “Constructing Turkish 'Exceptionalism”' 84). In this passage,

19 Landry describes the Sèvres Syndrome as a "legacy of fear and anxiety, however irrational," that has "left profound scars" and affected Turkey's relationship with the West ever since the Treaty of Sèvres, albeit the Treaty itself was never put into practice. Landry sees the Sèvres Syndrome as "symptomatic of unresolved attachment despite Republican attempts at a rupture from the Ottoman past" (Landry 134-135).

20 Turgut Özal (1927-1993) served as Turkey's prime minister twice, from 1983 to 1989, and as President from 1989 to 1993 . He was the founder of the Motherland Party (ANAVATAN). 
Yanrk identifies the hybridization policies of neo-Ottomanism as exceptionalist policies, translating the factual coexistence of several ethnic and religious groups into a system of harmonious peace and "Ottoman justice," implied in the modern understanding of the term 'multiculturalism' (ibid.). ${ }^{21}$ All the aspects that will inform what I shall term Ottoman Utopia in Chapter One, and, more generally, the projections of cultural hybridity that populate Turkish American texts pluralism, harmony, multiculturalism, good governance, stability, order, and peace (ibid.) - are listed by Yanık as the outcome of a "'selective reading' of Ottoman history" that ultimately contribute to the shaping of Turkish identity as an exceptional nation that emerged from an empire that we may call discursively "anti-imperial." What can be concluded is that Turkish American literature, albeit hoping to achieve a denationalization of the culture, distances itself from the exceptional discourse promoted by the Kemalists - based on a selective reading of Turkish history - to embrace a different one - based on a selective reading of Ottoman history.

\section{'Unearthing' and Embracing the Colonial Past}

Archeological practices that aim to metaphorically 'disinter' the empire's intangible heritage appear to be crucial to the transnationalizing discourse of Turkish American literature. ${ }^{22}$ In Shafak's fictional work, these 'archeological' efforts lead

21 Not only has the Ottoman Empire been equated to a "unique source of multiculturalism," but also to a "globalization" process ante litteram (Davutoğlu in Yanık, "Constructing Turkish 'Exceptionalism”' 86).

22 From an American Studies perspective, Pease writes that "the globalization of American Studies involved scholars in the work of recovering the memory of America's disavowed imperial past so as to erect [...] newly forged interpretive frameworks" (Pease 267). Völtz explicitly blames American exceptionalism for the burial of this imperial past: "[Americanists] retrieved an imperial legacy that American Exceptionalism had disowned" (Völtz, 27). Within the field of American Studies, the recovery of the disavowed colonial past seems to be carried out through an 'archeological' process of recovery. Americanists describe the colonial experience, and the transnational dimension it is necessarily associated with, as an existing substratum of violence and oppression made indiscernible by centuries of denial. Völtz speaks of the American transnational experience as something "invisible or inaccessible," "obstruct[ed] and conceal[ed]" by the force of nationalism. The task of transnationalism, at this point, is to disrupt nationalist narratives and "recover" America’s cultural multiplicity (Völtz 362-363). Fluck, Brandt, and Thaler argue that America's global past had fallen victim to an "institutional amnesia" (Fluck et al. 6), consequently, the retrieval of the disavowed colonial past is perhaps romantically - conducive to a lost organic whole. "Nationalism," Völz argues, 
to the recovery of Ottoman, Persian, and Arabic phrases, which appear in her texts often without a translation. "I do not only try to unearth the stories that have been buried under the ground by the Kemalists," Shafak explains, describing her own creative process, "I also try to unearth the words that have been kicked out of Turkish language. I bring them back" (Shafak, "Linguistic Cleansing" n.p., emphasis added). The idea of an organic national identity resurfacing from the disinterring process appears in Shafak in the shape of an "unreasonable synthesis" (Shafak, "Making Sense of Irrationality" n.p.), constituted by Turkey's numerous "discordant parts" (Shafak, "Once the Sick Man, Now the Chimera of Europe" n.p.) and contradictory selves. Shafak therefore defines her own writing as an attempt to bring the forgotten imperial heritage to the surface, in order to restore Turkey's multifarious selves. To accomplish this unearthing, Shafak resorts to the instruments of transnationalism. She shifts the focus of Turkey's identitarian narratives from a monocultural discourse to a multicultural one, fully acknowledging past and present cultural interconnections and how they shape Turkey's self-perception. Shafak's work shows her willingness to integrate the colonial past in Turkey's present identitarian narrations. ${ }^{23}$

In Turkey, the linguistic, cultural, and religious legacy of the Ottomans is not the only aspect of Turkey's imperial past identified by the Kemalists as an obscure pre-national Other and ejected from the ideological construction of the nation. One finds a variety of abject bodies that the nationalist discourse does not address: non-Turkish and non-Muslim minorities were associated with the pre-national experience and therefore divested of meaning in the Republican framework, or forced to partake in it by assimilating into a mono-ethnic idea of

"is the disturbing force that tries to obstruct and conceal organic flows of culture. Transnationalism [...] recover[s] an original organicism” (Völtz 363).

23 American Studies theories resort to similar depictions of a disavowed past that go beyond the archeological semantic field into that of mourning. In the U.S. context, Pease evokes the concept of "melancholy" related "not to the impossibility of mourning a lost object, but to the impossibility of Americanist scholars giving up on an object that was not lost and that they could not forget" (Brown in Pease, Re-Mapping the Transnational Turn 28). Moving to the Turkish context, Landry speaks of Ottoman history as of "a perpetually lost object, encrypted and incapable of being mourned" (152). For Landry, the impossibility of mourning the dead as a natural part of a nation's coming of age has been the cause of humiliation, and anxiety in Turkey. Landry also quotes Mahmud Mutman in "The Nation Form," according to whom the Ottoman legacy is a loss that cannot be properly articulated, but that "cannot be simply rejected either" (Mutman in Landry 152). 
Turkishness. ${ }^{24}$ As a result, the dramatic events tied to the imperial experience, such as the Armenian genocide or the Kurdish struggle for independence, remain unresolved issues that haunt the national present. Turkish American literature follows an itinerary of liberation of the individual from the fixed modes of belonging and self-representation prototyped by Kemalism. Turkish American literature incorporates abject identities into alternative historical narrations, complicates official historiographies with unofficial ones by women and ethnic minorities, and promotes interaction between those who do fall within the criteria of national citizenship dictated by Turkish nationalism and those who do not.

The field of transnationalism is very much in flux and there is no such thing as an accomplished transnational condition. The transnational agent, invested in the production of transnational identities, inhabits a void between the negation of previous nationalist models and the trans-nation - that is, a fully actuated transnational reality. The melancholia triggered by the yearning for a yet unachieved transnational condition becomes 'emplaced' in Turkish American literature through spaces that sensitize the reader about the necessity to develop a transnational conscience, which entails an open confrontation with the imperial past. The following chapters, especially Chapter One and Two, will be concerned with spatial representations of the transition from empire to republic, and from an imperial dimension to a nationalist one. Other spaces, instead, reflect a condition of restlessness and instability in which the monocultural discourses of Kemalism have plunged Turkish citizens. One of these is doubtlessly Café Kundera, a café in Shafak's The Bastard of Istanbul. Café Kundera is a space that exposes the limitations of nationalism and shows that this model has entered a crisis. The arrival of an Armenian girl, Armanoush, puts this aseptic space of unchallenged nationalism face to face with the abject Ottoman Other and with the ignominious events that the modern Republic of Turkey had ejected. Armanoush's appearance

24 U.S. nationalism also erased the individual subalterns that constituted its imperial experience. Subjects of Euro-American colonialism such as Native American tribes and African Americans, to put it with Briggs and McCormick, are "construed as signs of a colonial moment before the nation, or, if acknowledged to exist in the present, an unruly and ungovernable people who cannot be fully incorporated in the citizenry" (Briggs and McCormick 642). In this scenario, scholars of transnationalism are first of all endowed with the task of inaugurating new channels of interactions between the nation and those subjects that do not match the nationalist criteria of citizenship. Secondly, they develop different representations of the past by retrieving those that have been obscured by nationalist discourses, integrating them into present identitarian narratives. 
reveals that the space of Café Kundera is permeated with narratives of disavowal, and has not yet turned into a successful transnational space. Armanoush appears as a "liberatory" person in Bhabha's sense, one of those figures who "initiate the productive instability of revolutionary cultural change [...], themselves the bearers of a hybrid identity [...] caught in the discontinuous time of translation and negotiation" (Bhabha, "The Commitment to Theory" 21).

The Bastard of Istanbul also follows the transition of the Turkish protagonist Asya from a condition of cultural amnesia to one of awareness - a transition that is made possible by the interaction with an Armenian character. In The Bastard, Asya responds to the invitation to apologize in the name of the nation of Turkey for the Armenian genocide (Shafak 262). At this moment, the individual dissociates from the nation: "I have nothing to do with my state," Asya protests, "I am an isolated individual" and yet she does apologize for the pain her ancestors have caused to the ancestors of the Armenian characters in the novel (261-262). The nation's imperial past is therefore addressed and discussed: under these premises, the transition towards the transnational imaginary is finally possible. ${ }^{25}$

\section{Beyond Empire: A Postcolonial Reading of Turkish American Literature}

Considering its extensive engagement with imperial formations, I suggest that Turkish American literature can be read through the prism of postcolonial theory, or at least through some of its analytical concepts. Although Turkey has never been officially colonized, and, according to Kader Konuk, it appropriated Western culture on its own terms (Konuk, Mimesis 87), postcolonial theory emerges

25 Transnational American studies holds that nation-building processes in the U.S. excluded histories of Native Americans, of enslaved people, and of those who dwell at the physical and social borders of the country (see Pease, Transnational Turn 28). Halide Edip's autobiographical volumes, published a few years after the foundation of the republic, are driven by a similar need to question the exclusive narratives around which the nation was being built, and proposes alternative models where diverse voices could be integrated. The Turkish Ordeal subverts the official Kemalist historiographies and divests the mythical figure of Atatürk of its heroism, portraying the Turkish War of Independence as the successful outcome of collective efforts; she celebrates the courage of women left in the villages and entrusted with the onerous task of (re)constructing the nation. Most importantly, she views Turks and imperial minorities as united by the same grief. 
as a suitable instrument to illuminate the intricacies of the imperial and colonial experiences in Turkey. ${ }^{26}$

I derive my use and understanding of the term 'postcolonial' from the seminal text by Bill Ashcroft, Gareth Griffiths, and Helen Tiffin The Empire Writes Back: Theory and Practice in Postcolonial Literature (1989). As a starting point, the three scholars define the 'postcolonial' as a category that "covers all cultures affected by the imperial process from the moment of colonization to the present day" (Ashcroft et al. 2). Yet, their initial definition opens up to cover more contested spaces, and portrays the colonial experience as a much more ambivalent phenomenon, to the extent that, nowadays, postcolonialism is considered "one of the most diverse and contentious fields in literary and cultural studies" (Ashcroft et al. 193). The three authors are extremely cautious in defining the term: they manifest skepticism about "putting barriers between those who may be called 'post-colonial' and the rest," as the attempt to excessively contain the imperial discourse would affect the possibility to express its complexity (Ashcroft et al. 200). The Turkish context greatly benefits from the openness of the postcolonial model towards contested colonial experiences like the Turkish one, and the lack of an official "moment of colonization" (Ashcroft et al. 194) does not prevent the postcolonial model from representing a valid reading tool for Turkish American literature. Here, I am most inclined to define postcolonialism as a "reading strategy" (Ashcroft et al. 201) that may be applied to national cultures after the departure of the imperial power. Ideally, for Turkey, the notion of the postcolonial would have to cover the Turkish national experience as an example of postcolonial and postimperial modernity - one that marks the peculiarity and uniqueness of the Turkish context.

For Ashcroft, Griffiths, and Tiffin, postcoloniality is much less a historical condition than a 'reading tool' that may be applied to a variety of national realities affected by imperial processes. This concept can be adapted to meet the exigencies of my material: an evaluation of the "efficacy" of the postcolonial model to interpret a certain cultural reality (can I use postcolonial theory to read Turkish

26 In East West Mimesis, Konuk employs Bahbha's concept of mimicry to examine the anxieties connected to Turkey's Westernization. She states that some compelling parallels can be drawn between imperial dynamics in the British Empire and Republican Turkey, but she clarifies that her intention is not to equate "colonial strategies in British India with Turkey's self-imposed appropriation of Western culture" (87). The necessity of this comparison, instead, has been recently voiced by Mikhail and Philliou, Landry, and Aymes. 
American literature?) would replace "the debate over the validity" of the postcolonial label (is Turkey postcolonial?) (Ashcroft et al. 201).

Donna Landry and others apply the postcolonial framework to the Ottoman Empire, which has often been excluded from the discourses on Empire formulated by postcolonial scholars thus far. "Postcolonial literary studies," Landry states, "up to now dominated by the aftermaths of European, especially British and French, colonialism, needs to address the question of comparative imperialisms beyond the European" (Landry 127). The postcolonial framework has been used in connection with Ireland, earlier imperial and colonial periods, the European Renaissance, and many other instances (Ashcroft et al. 201), but its application to the Ottoman and post-Ottoman world is relatively recent. Landry's essay "The Ottoman Imagery of Evliya Çelebi: From Postcolonial to Postimperial Rifts in Time" and Selim Diringil's "They live in a State of Nomadism and Savagery: The Late Ottoman Empire and the Postcolonial Debate" establish parallels between the Ottoman and the British imperial experiences. On a similar note, Marc Aymes' "Many a Standard at a Time" and Alain Mikhail and Christine Phylliou's "The Ottoman Empire and the Imperial Turn" encourage scholars to evaluate the Ottoman Empire in a comparative light and to position its aftermaths within a postcolonial framework. These studies demonstrate that "the very question of empires, colonies, and nation-states is entering a new phase of investigation" (Landry 127) and the demarcation borders of the postcolonial, like those of the transnational, are still in the process of being defined.

\section{The Postcoloniality of Turkey}

Lerna Yanik argues that "through neither Turkey nor its precursor Ottoman Empire was ever colonized, both entities have had an uneasy relationship with the 'West' and displayed the reflexes of a post-colonial country" (Yanrk, "Constructing Turkish 'Exceptionalism”' 83). In his 2006 assessment of Turkey's postcoloniality, Erdağ Göknar explains that Turkey has been affected by forms of "semi-colonial" occupation:

As the late Ottoman state fell into the position of being semi-colonized, the legacy of this semi-colonization, or colonial encounter with Europe, informed the breadth, scope, and legacy of severity of the Kemalist cultural revolution that gave shape to the Republic of Turkey. And though it is a commonplace to hear modern Turks boast that Turkey meaning the Ottoman state and the Republic - was never colonized, history presents us with a quite different account. (Göknar, "Orhan Pamuk and the 'Ottoman' Theme” 37)

Here Göknar refers to the $19^{\text {th }}$-century cultural and financial dependency of the Ottoman Empire on Europe, but the occupation of the empire's territory by the 
Allied powers after the First World War and during the Turkish War of Independence qualifies as a "colonial encounter" as well. I agree with Landry's powerful claim that "the postimperial is not a rival to the postcolonial but its comrade" (127), with which she opens her study on Evliya Çelebi. This is especially true in Turkey's case, as the nation that rose from the Turkish War of Independence was not only a postimperial nation - being the successor to the Ottoman Empire - but a postcolonial one as well (see Landry 154). The new national formation, which contained part of the former imperial soil, also included portions of former imperial minorities who were never part of the ruling Muslim elite. They had thus far occupied the position of colonial subjects, but instead of inhabiting a "far-flung colony" they resided in the "imperial metropolis and its closest hinterland" (Landry 154). Furthermore, Landry adds, the struggle for independence led by Kemal and the successive political developments reacted not only against "the imperialist ambitions [...] of the external Great Powers but also against internal imperial Ottoman institutions" (ibid.). Landry's observations concur with Göknar's, who reiterates that "even though Turkey was never colonized, the official discourses of the Republic fabricated a clear distinction between the new national formation and what had come before, casting the Ottoman state centered in Istanbul as the 'colonizer' of Anatolia and the Turks" (Göknar, "Secular Blasphemies" 310). In other words, the Kemalists attempted to both eliminate the possibility of a foreign domination and to dismantle internal imperial structures and they saw the two as intimately connected, as the realization of the former would have depended on the connivance of the latter.

Ottoman financial dependency on and cultural indebtedness to the Western powers started in the post-Tanzimat era ( $19^{\text {th }}$ century) - much earlier than the collapse of the Empire, which brought about the specter of partition - and culminated with the Treaty of Sèvres in 1920. In her article, Landry uses a markedly metaphorical terminology that best clarifies the psychological impact of the European expansionist program in the former Ottoman territories. To describe the latter, Landry uses metaphors in the field of physical discomfort, such as "partition and acquisition fever" and a "European fever to possess the whole of the former Ottoman domains" that left "deep scars" on Turkish culture (135). These metaphors suggest the extent to which the possibility of a partition affected Turkey's psyche. The characterization of the Treaty of Sèvres as a "death warrant" provides further evidence of its shocking reception. Landry's sharp language, clearly sympathetic to the Turkish cause, is reminiscent of Edip's language of open distaste for Europe's expansionist designs during the War of Independence. Edip condemns the Allied powers as occupiers, persecutors and invaders (Edip, 
Ordeal 61, 106) who aim to "[convert] Turkey into a series of colonies" (Ordeal 112) or, alternatively, to "exterminate Turkish rule in Asia Minor and replace it by a vast Greek empire” (Ordeal 162). Edip's outrage never targets the United States, whose presence in Turkey is motivated, for Edip, by humanitarian reasons only. By so doing Edip perpetuates the myth of America's exceptionally 'unimperial' interference. Chapter Two of this volume, entitled "Rewriting History and Religion," will expand on that.

\section{Turkish American Literature and the Postcolonial Imagery}

The subtle coexistence of the colonial and the imperial in Turkey begs the question whether the postcolonial framework is an effective reading tool for Turkish American literature. A cluster of recurring themes and ideas that are central to both postcolonial theory and Turkish American literature suggest it is. These themes are place and displacement, botanic and natural imagery, syncretism, and resistance.

Ashcroft, Griffiths, and Tiffin describe the concern with place and displacement as a major feature of postcolonial literatures: the rift between self and place is where the postcolonial identity crisis is located. This theme finds large resonance in the present study: the discomfort provoked by the vanishing of familiar architectures and the proliferation of unfamiliar ones will be the object of Chapter Four. My investigation of gardens and botanic imagery shows how the disappearance of what I call 'Ottoman nature' - that is, nature used as a symbol of the country's Ottoman heritage - emblematizes Turkey's passage from empire to republic. Chapter One, instead, addresses imaginary representations of the Ottoman Empire that ensue from the aspiration to bridge the fracture between the master narratives informing Turkish modernity and the history of the territory on which it stands.

In both chapters, the experience of place is undistinguishable from the experience of language: the lost connection with the inhabited space corresponds to the incapability of finding words to describe it. Ashcroft, Griffiths, and Tiffin affirm that the

gap [which opens between the experience of place and the language available to describe it] occurs for those whose language seems inadequate to describe a new place, for those whose language is systematically destroyed by enslavement, and for those whose language has been rendered unprivileged by the imposition of the language of a colonizing power. (Ashcroft et al. 9) 
This gap between the experience of place and language is adopted by Shafak, most directly in an interview entitled "Linguistic Cleansing," where she claims that

linguistic cleansing is something comparable to ethnic cleansing. Imagination shrank, culture and information couldn't flow from one generation to another. We have generations of people who don't know the things their grandparents know, who cannot read the writing of their grandparents, who cannot read the names or who don't know the meanings of the street names. (Shafak, "Linguistic Cleansing" n.p.)

For Shafak the Kemalist language reform - which sought to minimize the Arabic and Persian lexical presence in Turkish - is akin to practices of ethnic cleansing. Kemalist language policies are thus paralleled to strategies of ethnic levelling. The Ottoman alphabet was "a mixture of many things, a multiethnic fabric" that the Kemalists changed "in a day" (ibid.). Besides equating linguistic with ethnic cleansing, this passage addresses the rupture of the unity of self, language, and place. Not only has the language reform isolated the younger generations from their cultural tradition (the "writing of their grandparents" allows access to "the things their grandparents know"), it has also simultaneously created a distance between them and their national space. Unable to read street names, they lose the possibility to navigate the city and country they live in, both geographically and culturally. ${ }^{27}$

At the same time, questioning the "appropriateness of an imported language to describe the experience of place in postcolonial societies," which the authors of The Empire Writes Back underline as a "classic and all-pervasive feature of postcolonial texts" (9), is particularly relevant for Turkish American literature, for which both English and Turkish are connected to different forms of Westernization. Turkish American literature represents a paradoxical scenario in which the search for national identity - not necessarily a diasporic one - is carried out in English, and presents narrative situations in which both languages are equally contested, equally insufficient. Edip wrote her autobiography in English, directing it to an Anglophone and international readership. Translations into Turkish only appeared in the 1960s, and bore important modifications that minimized

27 This rift is also clearly expressed in Pamuk's The Black Book, whose protagonist is consumed by his own inconclusive attempt to reconstruct the connection between the speaking subject, the signifier, and the signified. A postcolonial critique is very evident in The Black Book and The New Life, where one finds expressions of outrage against a not always intelligible constellation of imperial occupiers that seem to include Western as well as Westernizing forces such as Europe, the U.S., and Kemalism. 
the narrator's skepticism towards Kemal and his doctrines. Edip's work was banned from the Turkish cultural sphere for decades after publication, but also inaugurated a tradition of bicultural writing such as Turkish American literature. By the same token, Shafak's use of English has been harshly criticized in Turkey. "It caused a lot of reaction and bitter criticism in Turkey when people heard I had started writing fiction in English," Shafak admits in an interview, "people took it as a cultural betrayal" (Shafak, "Critical Outtakes" n.p.). Her literary production in Turkish, prior to the publication of The Saint of Incipient Insanities in 2004, was also perceived as politically oriented and became the target of antagonism due to her use of Ottoman, Arabic, Persian, and Sufi terms (ibid.). Rather than supplanting the mother tongue, English provided Turkish American authors with "an alternative medium which guaranteed a wider readership" (Ashcroft et al. 24) and a platform for the expression of a postnational identity. Besides, the use of English may be understood as central to the achievement of a cosmopoli$\tan$ condition and global citizenship ${ }^{28}$ (May 206), which is very much at the core of Turkish American literature. On a deeper level, nevertheless, a postcolonial analysis sheds light on the critical choice between a new, unfamiliar national language that became unsuitable to describe the national space (Turkish) and an overly familiar foreign language (English) - both bearing the mark of colonial, neocolonial, or, to use Erdağ Göknar's term, semicolonial interference (see Göknar, “Ottoman' Theme" 37).

Turkish American literature can also be related to postcolonialism by way of the recurrence of botanic imagery and garden symbolism. An increasing volume of scholarship has illuminated the significance of nature in postcolonial literature. Among the most relevant works one finds Graham Huggan and Helen Tiffin's Postcolonial Ecocriticism: Literature, Animals, Environment (2010) and Projections of Paradise: Ideal Elsewheres in Postcolonial Migrant Literatures by Helga Ramsey-Kurz and Geetha Ganapathy-Doré (2011). These publications explore the "foundational importance of animals and environmental concerns in theorizing the 'postcolonial"' (Ashcroft et al. 216) and show the suitability of "plant metaphors" to express the postcolonial condition, as they stress "age, experience, roots, tradition, and, most importantly, the connection between antiquity and value" (Ashcroft et al., 9). These elements are often indicative of a precolonial Eden that is set in contrast with an urbanized, green-less colonial modernity. The

28 See Stephen May, Language and Minority Rights (2012): "English, as the current world language or lingua mundi, is central to achieving both [cosmopolitanism and global citizenship]" (208). 
destruction, loss, or 'bulldozing' of ancient gardens and trees most significantly haunts Croutier and Shafak. Chapter Four will conduct an analysis of nature in Turkish American literature, focusing on its relevance for the debate on cultural hybridity and syncretism.

The centrality of botanic symbols and garden imagery in representing Turkey's passage from Empire to Republic finds substantial correspondences in postcolonial literature, which denounces how "the scramble for modernization has enticed developing countries into the destruction of their own environments" (Ashcroft et al. 213). Another point of conjunction between postcolonial and Turkish American literature is the representation of gardens as precolonial utopias featuring the unity of self, language, and place. The desire to retrieve the Ottoman garden and the precolonial, or in the Turkish case imperial, state is manifest in Turkish American literature. The Empire Writes Back is adamant in excluding the possibility of a return to that original state, but the issue is dealt with differently in Turkish literature and Turkish American literature. If on the one hand the courtyard in Pamuk's The Black Book is a space of loss and despair, nature in Turkish American literature combines practices of destruction and recreation. The vanishing garden is reconstituted under different forms and conditions, and botanic symbols accompany the stories of dispersal and re-aggregation of diasporic communities. One example for this is the Armenian family in The Bastard of Istanbul who, separated by the genocide, is reunited again thanks to a pomegranate brooch. The brooch allows an Armenian American character to recognize its bearer as his long-lost sister and convince her to follow him to the U.S., where the Armenian American community thrives in the folds of American multiculturalism. In another passage of the book, the pomegranate appears as a symbol for the disintegration of the Empire and the subsequent diaspora: "Once a pomegranate breaks and all its seeds scatter in different directions, you cannot put it back together" (Shafak, The Bastard 232). Yet, the novel contradicts this assumption by showing the reconstitution of clusters of Ottoman communities in the United States under the umbrella of a functioning multicultural model. To put it with Ashcroft, Griffiths, and Tiffin, nature in postcolonial literature gardens in particular - offers "newly ambivalent versions of the trope of loss and possibility $[\ldots]$. The reconstituted $[\ldots]$ garden thus becomes a space redolent of possibility" (214).

The different understanding of the garden in Turkish American and Turkish literature paves the way for the next theme that features prominently in postcolonial and Turkish American literatures, namely, the issue of syncretism. The tension between de-colonization and syncretism informs both the Turkish and the 
postcolonial literary debate. On the one hand, some voices argue that, within the framework of postcolonial studies, colonization is a contingent phenomenon that can be gradually but effectively wiped out from a country's collective consciousness (Ngugi in Ashcroft et al.28) to enable what Ella Shoat calls "the assertion of culture prior to conquest forms" (110). Hence, colonialism does not represent a constitutive part of a nation's self and should be expunged from it through a process of recovery of the precolonial state, which preserves the authentic self of the nation intact. On the other hand, numerous critics and authors position themselves in favor of integrating the colonial experience into the cultural and political debate about a nation's identity, hoping to achieve a synthesis - a "syncreticity" (Ashcroft et al.28) - of the precolonial and the colonial conditions. This category of texts, as opposed to the first, "espouse a cultural syncretism which, while not denying ancestral cultural affiliation, sees [the nation's] destiny as inescapably enmeshed in a contemporary, multi-cultural reality" (Ashcroft et al. 30).

In my analysis, the opposite poles in the debate on decolonization and syncreticity are represented by Pamuk's strongly anticolonial works, The Black Book and The New Life, and Turkish American texts. ${ }^{29}$ Pamuk is by no means comparable to postcolonial authors who take a stance in favor of the decolonization of the culture as a historically viable option - such as Ngugi Wa Thiong'o, quoted in The Empire Writes Back. ${ }^{30}$ For Pamuk, the delusional itinerary towards the recovery of an original, precolonial wholeness deceives its undertakers, who eventually give in to the shifting quality of notions such as cultural authenticity, and settle on a perspective of irremediable identitarian emptiness. By contrast, Turkish American texts are representative of the syncreticity argument in Turkey, as they recognize the inevitable nature of syncretism and hope to promote an inclusive understanding of the local culture rather than an exclusive one. ${ }^{31}$ In "Notes on

29 This study includes in-depth analyses of Pamuk's texts as a counterpart to Turkish American literature. Thus, Turkish American literary practices can be viewed in comparison with those of a Turkish author who writes in Turkish and is canonized as 'world literature.' By presenting the Pamuk phenomenon as similar and contingent to Turkish American literature, but not quite the same, I aim to stress the uniqueness of the Turkish American imaginary and legitimize its status as separate from what is understood by world literature in Turkish. Pamuk's peculiar position vis-à-vis Turkish American literature will be addressed in detail in Chapter One.

30 See Ngugi Wa Thiong'o, Decolonising the Mind: The Politics of Language in African Literature (1994).

31 Ella Shoat addresses the polarity between syncretism and resistance in her essay "Notes on the Postcolonial." The emphasis on hybridity/syncretism interferes with the search for a shared precolonial identity "as an archeological excavation of an idealized, 
the 'Post-colonial,' Ella Shoat warns her readers that syncretism or "hybridity"32 often feature as umbrella terms that do little justice to "the diverse modalities of hybridity," among which she lists "forced assimilation, internalized self-rejection, political cooptation, social conformism, cultural mimicry, and creative transcendence" (110). Thus, she urges to consider location and perspective when engaging with manifestations of the hybrid or the syncretic, and to address the "differences between hybridities" (110). Two main factors define hybridity/syncretism in the Turkish context and in Turkish American texts: first, a merging of the imperial and postimperial with the colonial and the postcolonial. Turkish American literature displays reflexes that have been ascribed to postimperial centers (e.g. imperial nostalgia and imperial melancholia, presented in Chapter One), while at the same time articulating responses that are generally associated with the sensitivity of the colonized (e.g. hyper- and re-Orientalism, in chapter Four). Second, popular narratives of Turkey as a bridge between East and West translate, in Turkish American writing, into the invocation of a merging of the disavowed Ottoman Islamic legacy and the successive Westernization measures that have projected Turkey towards Western politics, ethics, and aesthetics.

\section{Postcolonialism and Resistance: A Critical Perspective on Turkish American Literature}

Both Postcolonial and American Studies reserve a prominent role to resistance, which Fluck identifies as the nourishing utopia of American culture (Fluck 69). Homi Bhabha warns us about underestimating the subversive potential of texts that, in one way or another, traverse national borders and appear as hybrid formations. When one ignores the colonial disruption underneath the 'English' mimetic surface of a text, one forcibly re-inscribes the text into the hegemonic Anglophone tradition (Bhabha in Ashcroft et al. 33). Ashcroft, Griffiths, and Tiffin build on Bhabha's argument and suggest that texts gesturing at the complexities of imperial relations contain "global energies for interchange, circulation and transformation" that "may become weapons of resistance" (Ashcroft et al. 213).

irretrievable past" (119). Shoat also asks whether this fiction of precolonial unity which permeates Pamuk's mystical Golden Age - is necessary to enable the possibility of colonial resistance.

32 In "Notes," Shoat uses the terms hybridity and syncretism almost interchangeably. Here, I use syncretism in opposition with de-colonialization, but given the centrality of the botanic imagery in Turkish American literature, this study will privilege the term "hybridity." 
Postcolonial scholars like Bhabha or the authors of The Empire Writes Back are inclined to consider every postcolonial text as a potential locus of resistance, as long as it addresses, in form or content, how cultures interact within the frame of colonialism.

This viewpoint on resistance is counterbalanced by another influential text on postcolonialism: Michael Hardt and Antonio Negri's Empire, which critiques the postcolonial excitement with the hybrid as a liberatory form.

What if theorists are so intent on combating the remnants of a past form of domination that they fail to recognize the new form that is looming over them in the present? [...] [W] hat if a new paradigm of power [...] has come to replace the modern paradigm and tile through differential hierarchies of the hybrid and fragmentary subjectivities that these theorists celebrate? In this case $[\ldots]$ the postmodernist and postcolonialist strategies that appear to be liberatory would not challenge but in fact coincide with and even unwittingly reinforce the new strategies of rule. (Hardt and Negri 138)

Hardt and Negri do not stop at denouncing the hybrid as an insufficient critique of the subtler dynamics of contemporary global power, but also point at how the disintegration of national paradigms of thought is instrumental to new forms of global power to legitimize themselves. "The world market," Hardt and Negri warn, "tends to deconstruct the boundaries of the nation state. In a previous period, nation states were the primary actors in the modern imperialist organization of global production and exchange, but to the world market they appear increasingly as mere obstacles" (150). Hardt and Negri invite caution in considering postnationalism as a liberatory ideology, as it could amount to another way to dismantle old paradigms of power to legitimize new ones. Or, in a world literature scenario, it may traverse the boundaries of nationalist discourse only to subscribe to the hegemonic Anglophone tradition.

An example of how Turkish American literature may pose resistance to Kemalism but not to structures of global power is the romanticization of the Ottoman Empire. The retrieval of a highly idealized imperial past and its refurbishing as a feasible societal and political model for the future is reminiscent of Hardt and Negri, who argue that the call to overcoming the limitations of the national may coincide with a return to empire:

Postmodernist theorists point to the end of modern sovereignty and demonstrate a new capacity to think outside the framework of modern binaries and modern identities, a thought of plurality and multiplicity. However confusedly or unconsciously, they indicate the passage toward the constitution of empire. (Hardt and Negri 133)

The phenomenon of Ottoman nostalgia is not limited to Turkish American literature, but resonates more vastly in the literature and scholarship from and about 
the former Ottoman territories. Landry affirms that the rift in time that separates the conflictual national present of the former Ottoman territories from an idealized multicultural history should be traversed in order to "regain imaginative access to the Ottoman past" (Landry 141), embracing the myth of Ottoman citizenship as a system based on heterogeneity, borderlessness, and tolerance. Ultimately, Landry advocates "the recovery of Ottoman history" as "an opportunity for coming to terms with a past that offered an alternative future, an alternative Enlightenment from the path that was chosen" (ibid.) and states that "it has become possible to consider Ottoman precedents and alternatives to present violence" (ibid.). Although, on a geo-political level, the "constitution of empire" has not yet come to pass, the dangers intrinsic to neo-Ottomanist revivals have become evident in recent times. After pushing the country into an alarming climate of intolerance, repression of fundamental liberties and human rights, suspension of democracy, and religious radicalization, Turkish Prime Minister Recep Tayyip Erdoğan has earned the derogatory nickname of "Sultan"33 (especially in the German press) - one that powerfully underscores the politics of authoritarianism that characterize imperial domination and gestures at the crisis of the Ottoman utopia. The dramatic developments of recent Turkish politics - from the 2016 coup d'état to the persecution of intellectuals and vocal public figures and Erdoğan's repeated threats to dismantle gender equality measures - have proven the fiction of an Ottoman-inspired present to be a collective delusion.

While Landry encourages the use of a romanticized Ottoman Empire as a tool of resistance against the tenets of Turkish nationalism, such as religious and racial homogeneity, the suppression of difference, and the indisputable value of borders in marking who is inside and who is outside, Hardt and Negri invite caution in validating the cosmopolitan and the postnational as "liberatory" models.

The structures and logics of power in the contemporary world are entirely immune to the "liberatory" weapons of the postmodernist politics of difference. [...] Despite the best intentions, then, the postmodernist politics of difference not only is ineffective against but can even coincide with and support the functions and practices of imperial rule. [...] The postmodernist theories focus their attention so resolutely on the old forms of power they are running from, with their heads turned backwards, that they tumble unwittingly into the welcoming arms of the new power. (Hardt and Negri 142)

33 Consider for example the following headlines (my translations): "Erdogan [sic]: Vom religiösen Häftling zum türkischen 'Sultan”/Erdoğan: From religious prisoner to Turkish "Sultan” (Die Presse); "Recep Tayyip Erdogan [sic]: So wurde er zum türkischen Sultan"/Recep Tayyip Erdogan: This is how he became the Turkish Sultan" (Focus); "Sultan Erdogan [sic], der Vizekanzler”/Sultan Erdogan, the Vice-chancellor” (Die Welt). 
The last passage can be used to describe the trajectory undertaken by Turkish American literature vis-à-vis the Ottoman utopia. Formulated as a critique of Turkish nationalism - intended as an imported political fiction that did not respect the deep-seated multiculturalism of the Ottoman territories - the Ottoman utopia promotes imperial nostalgia on the one hand and a U.S.-centric model of cosmopolitanism on the other, as the Ottoman model that should inspire Turkish modernity is informed by American discourses of multiculturalism. Chapter Three will focus more closely, for example, on Shafak's The Forty Rules of Love and the commodification of Sufism for the American market.

As I hopefully clarified in this introduction, theoretical frameworks such as global and U.S. transnationalisms or migrant literature can be productively employed in the study of Turkish American literature, but these texts cannot be unequivocally labelled as representative of either Turkish, American, or migrant literature. The postcolonial framework offers appropriate instruments for a detailed analysis of literatures that are located in between two cultures, and which describe a colonial or imperial condition, but my material cannot be univocally categorized as postcolonial literature. I am aware of the variety of different approaches that can be adopted when looking at these texts. My study functions as an incentive for further research in the field of comparative literature that may cover the literary production of these authors in Turkish, or study Turkish translations of works they originally published in English. Evaluating the status and role of Turkish American literature within the landscape of Turkish national literature, or even attempting to define the latter, is beyond the purpose of my research. My scope here is investigating, and, when possible, facilitating the exclusive literary dialogue between America and Turkey these texts have opened. I am interested in asking where American literature, culture, and public debates become significant to read and understand Turkish American literature. This analysis comes from the conviction that the study of Turkish American literature can support scholars of American transnationalism in reaching their objectives: namely, the extension of the American Studies paradigm to non-American realities and views from 'the other side(s),' and the diversification of their working materials. 


\section{Imaginary Spaces: Representations of Istanbul between Topography and Imagination}

The present chapter revolves around representations of space, both real and imaginary, that display mechanisms of state-imposed repression and removal, but also prepare the ground for cultural encounters. The strongly comparative focus of this chapter begins to outline the difference between Turkish literature with an international readership and Turkish American literature, which originates and dwells in a diasporic dimension. The first section investigates representations of Istanbul in Shafak's The Bastard of Istanbul (2007) and Pamuk's The Black Book (1990) and The New Life (1994). Both writers imagine the city as governed by dichotomous ideologies: imitation and truthfulness, Americanization and authenticity, integration and segregation. Each of these abstract concepts is, using Amy Mills' term, "emplaced" (Mills 384) and spatialized, so that the city itself emerges as a dual entity where strongly oppositional universes dwell side by side without ever meeting.

The Black Book stages a conflict between an "overground city," dominated by Westernization and amnesia, and an "underground city" where relics of a forgotten past are simultaneously banished and preserved (Pamuk 191). A similar opposition emerges from The Bastard of Istanbul, where two cafés - Café Kundera and Café Constantinopolis - respectively embody a city burdened by historical amnesia and one obsessed by the excruciating preservation of memory. The discussion of ethnicity in Shafak complicates the configuration of these dichotomous spaces: while Café Kundera hosts an exclusively Turkish crowd, Café Constantinopolis is an online forum moderated and frequented by diasporic members of the former Ottoman minorities. I argue that Shafak decisively tries to overcome the insolvable dualisms that populate Pamuk's prose, and the two authors' diverging representations of Istanbul are crucial to proving my point. Pamuk dismisses the possibility of a productive encounter between Istanbul's two selves and insists on the vacuity of the search for an urban as well as national identity, while in Shafak a reconciliation between the two cafés, and thus between the oppositional ideologies that divide the city, is possible and advisable. Pamuk laments the indelible marks left by Westernization on the city and the nation, while Shafak responds by minimizing the impact of Kemalism on the city's everyday life and presents its hybridity, not its Westernized outlook, as its 
indelible trait. In other words, Shafak is invested in loosening the polarizations that characterize cultural debates in Turkey, in order to bring to the surface the richness and diversity of the Turkish cultural heritage (see Helvacioğlu 514).

The second part of this chapter will dwell on 'romanticizations' of the Ottoman Empire. Once again, my study establishes a comparison between what I term 'Ottoman utopia' in Shafak's writing and Pamuk's postulate of an Ottoman 'Golden Age.' Both constructions idealize Turkey's imperial past as a utopian model of cultural wholeness and express the wish to undo the historical processes that have caused the demise of Ottoman society. In spite of the many affinities between representations of Turkey's imperial heritage in Pamuk and Shafak, I propose that Shafak's Ottoman utopia is ultimately very different from Pamuk's Golden Age in so far as it emerges as a primarily transnational and diasporic narrative. By contrasting Pamuk's and Shafak's diverging approaches I hope to demonstrate that the tropes that are common to contemporary Turkish literature - in this case the perception of Turkish culture as fraught with dichotomies and the celebration of the Ottoman past (see Göknar, especially 305, 308, 309) - also figure prominently in the Turkish American imaginary, but Turkish American literature weaves them into a transnational, diasporic, and global perspective. In this sense, Turkish American literature is neither completely detached from national literary practices, nor does it seamlessly fit into the Turkish national literary scenario. Thus, Turkish American literature presents itself as a pool of complex, travelling texts that eschew canonization.

The study of cultural dichotomies is central to both Turkish and Turkish American literature: Göknar, for example, characterizes modern Turkish literature as negotiating the binary opposition of religion versus state. "The Turkish literary canon," he argues, "contains frequent examples of this dual articulation, summarized by the antinomy of din (religion) and devlet (state)" (Göknar 308). Göknar identifies Pamuk's work as highly innovative in this respect, as "Pamuk's novels establish culturally productive relations between din and devlet" (Göknar 309). From Göknar's perspective, Pamuk emerges as an innovator who brought two extremes of Turkish culture into a "productive parity" (ibid.).

The study of Pamuk in comparison with Turkish American literature underscores that both Turkish and Turkish American literature understand contemporary Turkish society as highly dichotomous and strive to return unity to what they perceive as a culture of paradoxes. The "emplacedness" of dualisms in The Black Book and The Bastard of Istanbul, their physical manifestation in the form of two cities and two cafés, makes these dichotomous visions of Turkey even more prominent. These two novels, however, and the literary traditions they are 
inscribed in, take different directions. If on the one hand Pamuk strives to overcome the dualism of religiosity and secularism, or East and West, on the other hand Turkish American literature focuses on annihilating the binary opposition between Turkey and the United States in particular. Not only does Turkish American literature renegotiate the significance of America in the construction of today's Turkey, it does so by presenting the Turkish and the American sensitivities as affine and intermingled. The Bastard of Istanbul shows that the dilemmas of modern Turkish citizens - torn between dwelling in a condition of statesanctioned amnesia and developing an excruciating awareness of their past are not so far removed from those of Armenian Americans, caught between assimilation and memory of a loss that is beyond healing.

\section{The Unplaceability of Orhan Pamuk}

Even though Orhan Pamuk's literary production does not qualify as Turkish American, it provides a crucial counterpart to Turkish American literature. The reasons why I deem appropriate to include Pamuk in this study are, first, the seemingly unplaceable status of his oeuvre, second, the politics of his texts, and third, the influence he might have had on Turkish American literature. Pamuk's career as a writer starts in the early Eighties with his first novel Cevdet Bey ve Oğulları (Mr. Cevdet and His Sons), published in 1982. His second novel, Sessiz Ev (Silent House; tr. 2012), followed in 1983. These two early works of Pamuk's are rooted in the Turkish literary tradition of social realism, which became prominent in the 1960s. The first English translation of Silent House appeared decades after its publication, while Cevdet Bey has yet to be translated into English. Pamuk's experimentation with postmodernism begins with Beyaz Kale (The White Castle), which was the first of Pamuk's novels to appear in English in 1990. The Black Book, which brought Pamuk international popularity and a great deal of controversy at home, was published in Turkish in 1990; a first English translation authored by Güneli Gün appeared in 1994, followed by a new one by Maureen Freely in 2006. In 1994, the publication of the Sufi novel Yeni Hayat (The New Life; tr. 1998) - released after Pamuk had become renowned for his support of Kurdish political rights - marked Pamuk's status as a prominent as much as controversial figure of Turkish literature. Pamuk's latest publications, constituting his best-known and most widely read works, include Benim Adım Kırmızı (My Name is Red, 1998; tr. 2001), Kar, (Snow, 2002; tr. 2004), the autobiography İstanbulHatıralar ve Şehir (Istanbul: Memories and the City, 2003; tr. 2005), Masumiyet Müzesi (The Museum of Innocence, 2008; tr. 2009), and Kafamda Bir Tuhaflk (A Strangeness in my Mind, 2014; tr. 2015). Pamuk also published collections of 
essays and non-fiction, among which Öteki Renkler (Other Colors 1999; tr. 2007) and The Naïve and the Sentimental Novelist (2011).

Like Turkish American literature, Pamuk's oeuvre defies classification. While some critics argue in favor of his prominent international status, others place Pamuk within the sphere of Turkish literature. Pamuk expert and translator Erdağ Göknar insists that, on the one hand, Pamuk needs to be positioned in a primarily national frame, as his work can be read as a response and an evolution of the tropes, politics, and concerns of the Turkish novel, although endowed with uncommon innovative strength. In Göknar's words, Pamuk's oeuvre "does demonstrate faithfulness to the modern Turkish novel even as it transgresses its traditions" ("Secular Blasphemies" 305). Additionally, Göknar points out that the erroneous belief that little or no knowledge of Turkish culture is needed to read Pamuk has resulted in "persistent misreadings," "half-formed interpretations," and "misconceptions" of his work (ibid.). Göknar goes as far as claiming that Pamuk's current literary career is haunted by a "post-Nobel fantasy of a 'return to origins"' and by the "attempt to resituate himself in the literary canon, as if to say, 'I am still one of you!'” (306).

Göknar, however, also recognizes that Pamuk's highly mobile biography and Westernized upbringing have contributed to the international character of his literary production. Born into a Westernized, upper-class Istanbul family, ${ }^{34} \mathrm{~Pa}$ muk graduated from American-owned Robert College (now Bosphorus University), travelled extensively to the United States, and resided there for several years. In the fall of 1985, he took part in the International Writing Program at the University of Iowa. In that same year, he went to Columbia University as a visiting scholar (1985-1988). He carried out great part of the research for The Black Book during these New York years, which also marked the beginning of a long-lasting affiliation with Columbia. In 2006 Pamuk returned to Columbia as a visiting professor, and from 2006 and 2007 he worked there as a lecturer. From 2009 to 2010, he delivered a series of lectures called "The Naïve and the Sentimental Novelist" (later collected into a book by the same title) as part of his duties as Harvard's Charles Eliot Norton Professor. Pamuk is currently the Robert Yik-Fong Tam Professor in the Humanities at Columbia. "Pamuk no longer

34 Pamuk's paternal grandfather built the first railroads in Turkey in the first decades after the foundation of the Republic, when the country was being modernized. When Pamuk reached adulthood, the family wealth had significantly decreased. Zlatko Anguelov categorizes Orhan Pamuk's family as one "which followed the cultural trend of fascination with the West and America that secular Turkish bourgeoisie after Kemal Atatürk embraced almost by default" (Anguelov, "Orhan Pamuk" n.p.). 
lives only in Istanbul," Göknar clarifies, "but in New York City, where he teaches a semester each fall at Columbia University" (323).

Whether Pamuk's Westernized socialization and his residence in the U.S. have impacted his writing, remains a controversial issue. Bulgarian American author Zlatko Anguelov dedicates an article to Pamuk's Iowa period and comments on the lack of reference to the American experience in Pamuk's writing.

Little, if anything, is left in the archives of both Columbia University and the University of Iowa about these visits. Pamuk himself has never mentioned them in his writings, fictional or non-fictional. [...] In none of [his stories] is there the slightest mention, not to say a lofty claim, of any intellectual or emotional interest in America, nor is there a hint of the reasons why the author was there. ("Orhan Pamuk" n.p.)

The second part of this statement is highly debatable, as Pamuk's work - especially The Black Book and The New Life - does show an interest in the United States. Although not as prominent as in Turkish American literature, forms of engagement with American culture and its impact on the newly born republic of Turkey are present in Pamuk's textual politics and will be returned to later in this chapter.

Other critics propose completely different readings of Pamuk's prolonged contact with the Westernized Istanbul élites, the English language, and, ultimately, the U.S. and its writing programs. These scholarly interventions portray Pamuk as a Western author in disguise, and construct a discourse of suspicion around his persona. Göknar himself admits that supposedly flawed readings of Pamuk's work have banished him "to the margins of Turkish national culture" and branded him a "native informant or an exotic exile in international circles" (306). Anguelov echoes Göknar and writes that, to the Anglo-American press, Pamuk became "somewhat of the Turkish native-informant" (Anguelov n.p.). In his essay "A Nobel Sensitivity," Horance Engdahl elaborates on this narrative of suspicion. According to Engdahl, Pamuk has been criticized by exponents of both Turkish conservative nationalists and Western postcolonial scholars. The former accuse him of being "too strongly influenced by Western values," and the latter argue that he was one of the non-Western authors to whom the Academy had awarded the Nobel Prize for their ostensible willingness to integrate their work in the Western canon while maintaining "an exotic guise," thus becoming agents of Western "cultural imperialism" (Engdahl 42). In his article "A Reading of the Turkish Novel," political scientist Kürşad Ertuğrul offers a comparison of three Turkish writers who, in his opinion, strive to define the modern condition in republican Turkey, namely, Orhan Pamuk, Ahmed Hamdi Tanpinar, and Oğuz Atay. While Ertuğrul applauds Tanpinar and Atay for their complex and ambivalent understandings of Turkish modernity, he positions Pamuk rather 
categorically in a Western space. To Ertuğrul, Pamuk's idea of Turkish modernity is a "conventional" one that "coincides with Westernization" and in which individualization is synonymous with "the replication of Western individuality" (Ertuğrul 646). Moreover, this "full replication/emulation of 'Western individuality"' is achieved through a "total disavowal of the 'Eastern' way of existence" and "of the image of Turkish people's Eastern social and cultural life" (642). Ertuğrul's view may be reductive, but his article provides a useful example of the ways in which Pamuk has been discursively ejected from the Turkish literary context. As early as 1992, Pamuk's former translator Güneli Gün provided a striking commentary, claiming that Pamuk's work "translates into English like a charm [...]. English is, in fact, the common language behind the various languages out of which the new world voice is being created - like world rock music - the destination of which is also the United States" (Gün 59, 62). Although Gün appears skeptical of theories that view Pamuk as a product of American creative writing programs ${ }^{35}$ she regards Pamuk's Turkish as designed to adhere to the structure of the English language, thus shortening the passage from the original to the English translation.

In a completely different register, other voices attack Pamuk's interest in the retrieval of Ottoman themes, casting it as a sign of political conservatism. "Because Pamuk reintroduces urban Ottoman, Sufi, and Islamic forms into the republican novel," Göknar observes, "his work is sometimes read as retrograde, regressive, or even orientalist by his contemporaries in Turkey" (Göknar, "Blasphemies" 310). A reference to Shafak is in order here, as she repeatedly hinted at the fact that she had to face similar accusations, especially due to her use of an Ottomanesque language. Shafak expresses concern over the effects of the Kemalist language reform in terms that evidently connect to a "disenchantment" (Göknar 310) of the

35 In the same article Gün claims: "as John Updike somewhat biliously points out in his New Yorker essay on Pamuk and the Czech Ivan Klima (2 September 1991), it might be the Iowa International Writing Program that fosters a global voice. True, Pamuk has put in an almost obligatory stint at Iowa; but the global voice is more likely to be tied to world economics, I suspect, than to Midwestern schools playing host to world writers" (Gün 62). The article Gün references is Updike's review of The White Castle, entitled "Vagueness on Wheels, Dust on a Skirt" and published in the New Yorker in 1991. Here, Updike sees similarities between Pamuk and the Israeli Palestinian author Anton Shammas, who, like Pamuk, attended the International Writing Program at the University of Iowa. Hence, Updike wonders: "Can it be that literary historians of the future will have to speak of 'the Iowa school' of global magic realism, and ponder the stylistic relation of Grant Wood's geometric landscapes to the exotic visions of Third World intellectuals?" See John Updike, "Vagueness on Wheels, Dust on a Skirt" (1991). 
Turkish novel caused by Kemalism. "The novel, as the genre of Westernization and modernization, as the locus of transformation, gained unusual importance. [...] The mainstream language of the Turkish novel became a disenchanted language and remained such" (Shafak, 2005: n.p., emphasis added). In an interview with Alison MacDonald, Shafak comments on the politicization of words in Turkey: "if you are open minded, if you are liberal, if you are a leftist you shouldn't be using those old words" ("Linguistic Cleansing" n.p.). In another interview she admits to having been "bitterly criticized for using Ottoman words in [her] writing" and at the same time "people took [the fact that she wrote in English] as a cultural betrayal” ("Critical Outtakes" n.p.). Understandably, her combined use of Ottoman words within English prose turned out to be highly controversial.

The fascination for Ottoman culture and the aspiration to integrate it into Turkish modernity is not the only contact zone between Pamuk's textual politics and those of Turkish American literature, as the comparison with Shafak has exemplified. Similar to Turkish American literature, the focus of much of Pamuk's work lies on transgressing the official narratives of Turkish identity enforced by Kemalism and challenging the uncompromising secularism of the republic. In doing so, Pamuk engages in what Göknar calls the "reenchantment" of the Turkish novel, "disenchanted" by Kemalist secularism and modernization (Göknar $310,311)$. This practice leads to the construction of a composite Turkish identity that synthesizes "various unreconciled contexts" such as "secular nationalism, European Orientalism, Islamic mysticism (or Sufism), ${ }^{36}$ and the historical legacy of the Ottoman Empire" (305). The elements involved in the process of reenchantment are very close to the interests and concerns of Turkish American literature and to the narrative this study will contribute to identify. The emphasis of Turkish American literature on Sufism and the Ottoman cultural legacy, combined with an openness towards the impact of Westernization and Americanization on Turkey, results in the construction of modern Turkish identity as an "unreasonable synthesis" of "discordant parts," ${ }^{37}$ as Shafak describes it in her

36 Göknar lays great emphasis on the theme of Sufism, indicating that its popularity in contemporary Turkish literature may be a result of Pamuk's work. “The recuperation of Sufism in literature is a topic that demands further study. Maligned during the era of Turkish modernism [...] Sufism as a cultural influence has made a resurgence in Turkish literature since 1980 through the influence of Pamuk's work" (Göknar, "Blasphemies" 311). For an analysis of Sufism in Turkish American literature see chapter three in this volume ("Sufism in America and Turkey: A Transnational Dialogue").

37 "Turkey is a bit of a chimera - the fire-breathing she-monster in Greek mythology with a lion's head, a goat's body and a serpent's tail. Just like this mythological creature, 
articles "Making Sense of Irrationality" and "Once the Sick Man, now the Chimera of Europe" (Shafak n.p.). The focus of Turkish American literature on the city of Istanbul as an ethnically and religiously composite space that resists superimposed monocultural narratives and at the same is able to absorb the impact of Westernization is affine to Pamuk's "complex contexts of Istanbul cosmopolitanism that synthesize internal and external influences" (305).

Göknar suggests that, from the Eighties on, Pamuk revolutionized the Turkish literary field in so far as he popularized a politicized posture that challenges and transgresses the ethnicist ideology of Kemalism, celebrating cosmopolitanism. Under the influence of Pamuk, themes of "cultural redefinition" that "make [a] [...] political argument against secular modernity and the republican state" became ubiquitous in Turkish literature (Göknar 305). It is therefore important to acknowledge that Pamuk may have functioned as a trend-setter for Turkish American literature as well, which positions the same themes in a transnational perspective and magnifies their potential to provide the bases for intercultural encounters. This study analyzes some themes and tropes that appear in both Turkish American literature and Pamuk's texts with the aim to stress where Turkish American literature and Turkish literature with an international appeal differ. The last point is particularly useful to shift the focus of this analysis from the affinities between Pamuk and Turkish American literature to their differences.

The question that ensues from acknowledging the similarities that bind Turkish American literature with Turkish literature is whether Turkish American literature can indeed be addressed as an autonomous phenomenon - developing alongside and yet independently from literature in Turkish. As already mentioned, the tendency to deconstruct narratives of Westernization and secularism is not limited to Pamuk's oeuvre, but it is a recurring feature of Turkish literary modernity (Göknar, "Blasphemies" 304). In spite of the important common grounds Turkish and Turkish American literature share, due to their language and their binational quality Turkish American novels cannot be placed (or at least not exclusively) in the Turkish national literary arena. Responses to Kemalism and propositions of different models centered on cosmopolitanism and hybridity are widespread in Turkish literature, and they also emerge as an essential feature of Turkish American literature. The latter, however, designates Ameri$\mathrm{ca}$ as the main interlocutor in the development of these new cultural models and strives to bring to light cultural affinities between the two countries. These

Turkey consists of numerous discordant parts" (Shafak, "Once the Sick Man, Now the Chimera of Europe" n.p.). 
affinities are, perhaps paradoxically, not found in the Westernization policies of Kemalism - an ideology these novels mostly contest - but in projections and representations of the Ottoman Empire.

The first obvious difference between Turkish American literature and Turkish literature - including Pamuk - is the language and the market of publication. Although Pamuk is widely translated and counts on an international readership, his works are written and published in Turkish to be translated and distributed worldwide at a later stage. While Göknar insists that knowledge of the Turkish context is essential for an accurate understanding of Pamuk's work, Turkish American novels explicitly target international readerships. In her study on ReOrientalism in South Asian literature in English, Lisa Lau has described diasporic writers as "perhaps those who play to the gallery and target a readership that, they comfortably suppose, has little or no knowledge of South Asian customs and cultures" (Lau, "Re-Orientalism" 582). I believe the same observations apply to Turkish American literature, as it aims to present the home culture to international readerships, at times hybridizing it with American elements.

This section has clarified that Pamuk's position within the Turkish literary field is contested and ambivalent. Turkish American literature inhabits an even more ambivalent space (Shafak has been addressed as a "so-called citizen of Turkey" by filmmaker Halit Refiğ $)^{38}$, and has been described here as a group of highly mobile texts travelling from a Turkish to an American cultural context and resisting affiliation. However, Pamuk has displayed a 'placement anxiety' that does not seem to be present in Turkish American literature. Göknar wrote about Pamuk's recent attempts for a reconciliation with the Turkish literary community, including a guest-editorship in 2007 at the Turkish daily newspaper Radi$\mathrm{kal}$, which he used to pay homage to such leftist writers as Nâzim Hikmet, Yaşar Kemal, and Sabahattin Ali. Göknar speaks of this moment in Pamuk's career as a "fantasy of a 'return to origins",' an attempt to resituate himself in the Turkish literary canon and possibly an "apology" for having so profoundly transformed its discourses ("Blasphemies" 306). Another "gesture of reconciliation" bordering on an apology is, for Göknar, Pamuk's Nobel Prize Lecture, which he delivered in Turkish. Ultimately, Göknar points out that in the Turkish version of Other Colors (Öteki Renkler, 2008) Pamuk acknowledges his artistic indebtedness to a series of Turkish authors who are not mentioned in the English translation.

38 From an eponymous article published on Turkish Daily News on December 2005: "Refiğ describes me as a 'fully fledged anti-Kemalist' and declared me a 'so-called citizen of Turkey"' 
Göknar reads this omission as evidence of a "profound anxiety," on Pamuk's part, of his own "influence and reception" (306).

By contrast, Turkish American literature exists in the interstice between the American and the Turkish literary traditions and adapts to this condition with varying degrees of comfort. The most helpful examples are Alev Lytle Croutier and Elif Shafak, as both of them explicitly locate their biographies and literary output in a space between cultures. When commenting on her work, Croutier is cautious about positioning it: "Having been an expatriate for more than 30 years," Croutier explains, "I haven't grown up with the changes that would have made me part of the Turkish literary machinery. I am a foreign writer to the Turks, and I'm a foreign writer to the Americans. I write in English and get translated into Turkish." Croutier regards her position as "odd [...] and in a way difficult, because I don't belong anywhere" (Croutier in Anon., n.p.). While carefully eschewing all affiliations, she grounds her origins in a quasi-mythical Turkey, where she claims she could have a taste of the secretive life of the harem. At the same time, Croutier strongly dismisses the idea of going back to her home country and admits to feeling "oppressed at the thought" of it (ibid.). Croutier also differentiates her authorial status from Orhan Pamuk's, branding him as a national author, as opposed to her self-identification as an expatriate writer in a "unique" position and possibly closer to the canons of world authorship. "Writers who live [in Turkey], like Orhan Pamuk," Croutier explains, "look at it with a close-up lens, and I am looking at Turkey with a tele-photo lens" (ibid.). Thus, Croutier oscillates between self-narratives of distance from and proximity to her native country, simultaneously constructing herself as an insider and an outsider.

Elif Shafak frequently recurs to the 'threshold' metaphor to represent her own writing, thus setting her literary work apart from Turkish literature in Turkey. In her 2005 article "The Gathering Place of the Djinni," Shafak writes that thresholds are "very difficult [...] to put into words when writing in Turkey and in Turkish" (Shafak n.p.), as the modern Turkish language as well as the Turkish context are unable or unwilling to come to terms with the notion of inbetweenness. This "zone that belongs to neither 'here' nor 'there,' neither 'inside' nor 'outside,' neither 'East' nor 'West" is, to Shafak, "a space of ambiguity and inbetweendom that is most difficult for a writer to describe" (ibid.). ${ }^{39}$ Her choice

39 This claim appears very often in Shafak's writing. In The Bastard of Istanbul, for example, one character reflects on the impracticalities of being in between and wishes Turkey would do more to move beyond this unfortunate and unstable state of being - a position that is forcibly challenged by other characters. However, it is also important to remind readers that Turkey's peculiar position in between two continents has been 
of English as a literary language emerges therefore as a strategy to properly communicate the importance of physical, literary, and metaphorical thresholds, as, in Shafak's understanding, English allows "more space for ambiguity and flexibility" (ibid.). The image of the threshold is crucial to Shafak's understanding and positioning of her own writing as neither Turkish nor English: "While my nationalist critics kept asking where would I now belong, 'either to Turkish or to English literature?' I believe their question is wrongly and rigidly formulated. I believe it is possible to be 'both... and...' instead of 'either... or...' in this world, or at least in the world of fiction" (ibid.). Eventually, she concludes that "writing fiction necessitates thresholds" (ibid.). Through this statement, Shafak makes an important claim to interstitial authorship which, rather than an occasion of discomfort, appears as a resource and a label both Shafak and Croutier wear with ease.

\section{Orhan Pamuk: Overground and Underground Istanbul}

Lisa Lau notes that "diasporic authors necessarily have different concerns from home authors, consequently different themes in their writings" ("Re-Orientalism" 589). The following section will lay emphasis on thematic overlaps and differences between Shafak and Pamuk, whom this study addresses as examples of "diasporic" and "home" authors respectively. Constructions of nostalgic, imaginary spaces proliferate in Orhan Pamuk's novels in the form of dreamlike city landscapes and concatenations of symbols. Göknar defines Pamuk as an author "in the writerly pursuit of new, imaginary spaces" (Göknar, "Ottoman Theme" 34): The New Life and The Black Book feature a similar yearning for a lost unity of sign and meaning, of language and culture. Osman, the narrator of The New Life, sees a woman reading a book, which he later purchases from a stall. This mysterious book narrates of a different world and a new life, but the reader of The New Life is left to wonder about its contents and nature. The narrative follows Osman's agitated search for the universe described in the book, leading him deeper and deeper into folly and self-deception.

The representations of imaginary Turkeys and imaginary Americas that constitute the focus of this chapter prove functional to the search of a post-Kemalist

addressed by many Anglophone studies on Turkey as a kind of "Turkish Exceptionalism." A discussion of Turkish Exceptionalism appears in the introduction to this volume. See Lerna Yanık “Constructing Turkish 'Exceptionalism': Discourses of Liminality and Hybridity in Post-Cold War Turkish Foreign Policy” and “Turkish Exceptionalism and its Critics." 
Turkish identity. This is one of the most evident concerns of The Black Book, which aims to subvert the polar notions of pre-republican 'authenticity' and hybridity as the two main directions dominating the search for this new Turkish identity. The Black Book critiques these concepts for their abstractness and impracticability and, at the same time, stages a series of imaginary scenarios showing Turkey as it would be if either of these principles were to be enacted.

In The Black Book, Istanbul appears as a 'double city. While the surface succumbs to the succession of new names and empires - the Achaemenid, the Roman, the Eastern Roman, the Ottoman - the underground hosts the defeated civilizations, which gradually accumulate and compose a hybrid 'museum'40 that gathers the "old, discarded objects that make us who we are" (188). During a visit to a mannequin shop, the guide explains to Galip and some English tourists that

each incarnation of this city - Byzantium, Nova Roma, Anthusa, Cospoli, Istin-Poli had beneath it in the underground passages in which the previous civilization had taken refuge. This had led to an extraordinary sort of double city [...] with the underground city ultimately wreaking revenge on the overground city that had supplanted it. (191)

The Black Book suggests that the city on the surface has been taken over by yet another colonizing agent - in this case, European and American literature, films, and commodities. This has forced Turks into alienation and imitation of foreign cultural practices, whereas the underground city preserves the remnants of the former, collapsed civilization - the Ottoman Empire.

The overground city seems plagued by a general loss of meaning. In one of his columns, fictional Istanbul journalist Celâl ${ }^{41}$ writes:

I imagine the amazement of a man who discovers that all the things have a second meaning. I imagine a parallel universe, hidden inside the one we inhabit, and I imagine myself wandering intoxicated about its new and sparkling streets, as the objects around me open like flowers to reveal their interior selves. I imagine the amazement of a man who lost his memory. I imagine I've been abandoned in a ghost city I've never seen before, where everything, but everything - the neighborhoods that once where home to millions, the avenues, mosques, bridges and ships - is empty. (249)

The excerpt displays what Ian Almond understands as the "nostalgia for a lost present" that permeates Pamuk's work and The Black Book in particular: a futile longing for a vanished reality, in which the meaning of Turkishness resided

40 For a discussion of the anti-museumizing function of underground structures in $\mathrm{Pa}$ muk, see Chapter Four of this volume: "Ottoman Nature: Natural imagery, Gardens, Wells, and Cultural Memory in Republican Turkey."

41 I derived the spelling of the name from Maureen Freely's 2006 translation. 
(Almond 81). The "ghost city" is characterized by emptiness and meaninglessness, a condition caused by the loss of individual and cultural memory. A system in which the visible city is nothing but an envelope to a sparkling universe of meaning would be the object of Michel Foucault's skeptic considerations in "The Order of Discourse." In his essay, Foucault invites caution in locating, beneath a "system of rarefaction," "a vast unlimited discourse, continuous and silent, which is quelled and repressed $[\ldots]$ and which we have the task of raising up by restoring the power of the speech to it" (Foucault 67). Foucault's point helps to acknowledge the narrator's naïve essentialism - which locates an 'authentic' cultural dimension beneath the visible modernity - and to recognize the Manichean division between the two worlds, or cities, as delusional, as "discourses must be treated as discontinuous practices, which cross each other and are sometimes juxtaposed with one another" (ibid.).

The loss of meaning should not be understood in metaphysical terms only, but also in very practical ones. Istanbul appears as a malfunctioning city where every piece of street furniture seems to have lost the memory of its function: "sallow streetlamps cast more shadows on the ground than light," "fountains [...] had gone dry," on the squares all one sees are "empty pools, forgotten statues and broken clocks" (Pamuk 314-315). This loss of meaning and function is particularly remarkable when it affects buildings of specific cultural value such as mosques. Accompanied by an old acquaintance, Galip visits the Süleymaniye mosque, one of the most representative Istanbulite sites, only to become aware of its desolation, as the great significance it used to have for the city has become exhausted:

this great edifice was as impenetrable as stone itself. It did not welcome a man, nor did it transport him to a better place. But if nothing signified nothing, than anything could signify anything. For a moment he thought he saw a flash of blue light, and then he heard the flutter of what sounded like the wings of a pigeon, but then it returned to its old stagnant silence, waiting for the illumination that never came. [The things around him] seemed to be crying out to him, to be crying Give us meaning! (Pamuk 198)

The picture emphasizes the non-existent interaction between citizens and urban structures, replaced by the impossibility of communication between individuals and what had once constituted their familiar environment. Confronted with one of the most poignant symbols of his culture, the mosque, the narrator fails to recognize this space as inspiring or culturally significant, except for a vague presentiment immediately driven away. The profound displacement experienced by Galip in the mosque is far away from the dazzling vision of objects opening like flowers to display their meaning, and rather unveils a city of emptiness, containing but the faintest remembrance of a glorious past of unity between objects and their meaning. 
The Süleymaniye mosque passage discloses more important characteristics of the surface city, such as its vagueness and fluidity. What meets Galip's eyes as he sits on top of the minaret, is an uncertain, ectoplasmic arena of ongoing transformations:

he could almost believe that he was looking at the surface of a planet that had yet to find its final shape. The domes of the city and these vast stretches of concrete, stone, tile, wood, and Plexiglas were coming apart, and in the cracks you could just see the underworld's molten glow - but not for long. Soon the city was sketching in its details; among the walls, chimneys and rooftops they could now see billboards, advertising banks and cigarettes, and as their giant letters emerged from the mist, the imam's tiny voice came bursting through the loudspeaker right next to him. (Pamuk 199)

Strangely enough, the vision of the city as a progressing construction site is not quite associated to a city in the making, but rather to one on the verge of vanishing. The indeterminacy of the urban landscape that presents itself to Galip is conveyed not only by the mist gradually thinning out, but also by the ongoing struggle between an old skyline (domes, roofs, and chimneys) and a modern one (billboards advertising banks and cigarettes). The feeling that Istanbul has yet to find its final shape does not exclusively depend on the fog impairing the narrator's sight, but especially on the competing forces of tradition and modernity, or, more precisely, the legacy of the Ottoman Empire and its typical architecture and the skyline of a modern, Westernized city. In spite of the majestic dimensions of the Süleymaniye mosque, towering over the Bosphorus, the imam's voice coming from a loudspeaker seems "tiny." This suggests the disadvantaged position in which the Ottoman and Islamic legacies find themselves in the process of modernization.

If overground Istanbul stood for a dispossessed civilization, underground Istanbul is the imaginary keeper of cultural 'authenticity'. It is not by mere chance that repugnant accounts of what lies underneath visible surfaces are very frequent in The Black Book. ${ }^{42}$ If the surface is dominated by imitation, the underground is where Turkish culture has evolved independently from the impositions, ruptures, and modifications operated by Westernization, Americanization, and Kemalism. The underground city hosts an alternative idea of Turkishness characterized by

42 Besides the forgotten objects in "The Dark Airshaft," Pamuk's fascination with the underground emerges also in "When the Bosphorous Dried up" and "Do you Remember Me?" where the narrator describes what lies on the bottom of the Bosphorus and in the city's underground tunnels. My analysis of wells in Chapter Four ("Ottoman Nature") explores the important role underground structures - cellars, basements, wells, tunnels - play in the retrieval of Turkey's collective memory. 
the stratification of all the cultural influences that had impacted Turkey through the ages: the early Persian colonization, the Ottoman Empire, the Islamic tradition, and, finally, the Western influence and the Republic. The underground city consists of large amounts of objects that have fallen from the upper world onto the lower, have been forgotten, and have gathered in the bowels of the city and on the bottom of the Bosphorus. The chaotic juxtaposition of all the cultural traditions that made Turks "what they are" - to use an expression that recurs frequently in The Black Book - indicate that Turkish culture is fundamentally hybrid. The image critiques the cultural selection operated by the Kemalists, who constructed a Turkish national identity based on American ideals and European nationalisms, overshadowing the Islamic and imperial legacy as they did not fit the Western ideal of a modern national state.

The overground city and the underground city represent oppositional discourses that "exclude or are unaware of each other" (Foucault 67). At the same time, Pamuk's representation of Istanbul as a dual space seems to find a correspondence in Shafak's The Bastard, where two cafés embody oppositional 'civilizations' that coexist in Istanbul without ever meeting. This parallel attests to Pamuk's role as a trend-setter in contemporary Turkish literature, but is also useful to underscore how Shafak's work draws from Pamuk's themes but ultimately deviates from them.

\section{“Safe Spaces of the Like-Minded": Elif Shafak's Cafés}

Through the representation of "Café Kundera" and "Café Constantinopolis," Elif Shafak's novel The Bastard of Istanbul investigates the ongoing search for Turkish identity, portrayed and synthesized by the author as a clash of opposites that needs to be overcome: East and West, Turkish majority and former imperial minorities, nationalism and cosmopolitanism, cultural homogenization and cultural pluralism. The walls of these cafés isolate groups of individuals who share rigid conceptions of identity, sheltering them from interaction with the quicklyevolving outside world. At one extreme, Café Kundera's Turkish customers appear preoccupied by Turkey's in-between condition and terrified by its internal divisions. Failing to understand the constructive potential of in-betweenness as a foundational value of Turkishness, they indulge in the perpetration of nationalistic narratives, including the denial of the Armenian genocide. At the other extreme, the Armenian American community meeting online at Café Constantinopolis is portrayed as static and impermeable to change. At Café Constantinopolis, the legitimate hope that Turkey will recognize the Armenian genocide and apologize officially is entangled with very radical positions against all Turks, 
sometimes amounting to indiscriminate intolerance against an entire population. Eventually, the introduction of an element of Otherness in these "Safe Spaces of the Like-minded," to quote the title of a 2006 essay by Shafak, violates the until then impermeable membrane between the inside and the outside and helps pave the way towards the acknowledgement of Turkey's inherent hybridity: an idea that challenges nationalistic perspectives that have shaped the making of post-Ottoman identities, both national and diasporic.

Café Kundera hosts a variety of displaced personages the narrator identifies as Istanbul's "nihilists, pessimists, and anarchists," fascinated by the idea of extinction and leading lives of utter meaninglessness (811). The cafés walls are covered in framed landscape pictures that encourage customers to indulge in escapist fantasies: in fact, customers seem to share the desire to leave the city and live a different life in a faraway place. The most salient trait of the cafés guests is their dissatisfaction over contemporary society, accompanied by the uncompromising unwillingness to change things. Terrified by interaction with the outside world and by the liveliness of Istanbul, the guests of Café Kundera find refuge in the café and in their inconclusive conversations.

Café Constantinopolis is an online chat room that offers a virtual platform for the American descendents of former Ottoman minorities to reunite, discuss their common roots, and fantasize about an imaginary afterlife of the Ottoman Empire where Turks are discriminated or denied entrance. Café Constantinopolis presents the U.S. as the ideal place for diasporic Armenians, Jews, and Greeks to re-locate and preserve their traditions: thanks to American multiculturalism, Ottoman cosmopolitanism could outlive the Ottoman Empire. Nevertheless, the revival of Ottoman cosmopolitanism embodied by Café Constantinopolis is an imperfect one, as it forcefully excludes the Turkish element.

Michel Foucault's notion of "heterotopias" sheds powerful light on the function of these two cafés in the novel:

there are also, probably in every culture, in every civilization, real places - places that do exist and that are formed in the very founding of society - which are something like counter-sites, a kind of effectively enacted utopia in which the real sites, all the other real sites that can be found within the culture, are simultaneously represented, contested, and inverted. Places of this kind are outside of all places, even though it may be possible to indicate their location in reality. Because these places are absolutely different from all the sites that they reflect and speak about, I shall call them, by way of contrast to utopias, heterotopias. (Foucault, "Of Other Spaces" 3).

Both cafés are doubtlessly "outside all places": Café Constantinopolis is an online platform and thus lacks a physical dimension, while Café Kundera, "a fictive place with fictive people as regulars" (76), exudes a fictional quality that 
locates it outside the physical space of the city. Yet, they are both very real to their guests. The two protagonists, Asya and Armanoush - regular customers of Café Kundera and Café Constantinopolis respectively - think of their cafés as their "sanctuar[ies]" $(86,111)$. Armanoush openly compares it to a real bar: "Armanoush liked to imagine this forum as a dingy, smoky bar she habitually stopped by on her way home [...] where you could forgo your true, humdrum Self at the entrance, like leaving a sopping raincoat in need of drying in the vestibule" (111). These spaces resemble utopias but ultimately deviate from this notion: Café Kundera's guests seem to be able to find meaning only among the Cafés walls, but the place is pervaded by resignation and cynicism. The founding members of Café Constantinopolis aimed to provide the descendants of former Ottoman minorities in America with a safe space where they could celebrate their shared cultural memory, but their discussions exude rage and intolerance. Most importantly, both spaces appear to simultaneously "represent, contest, and invert" the culture that hosts them. Café Kundera is, in the narrator's words, "the negation of the whole city" (83). Café Constantinopolis is named after the city it represents, but by celebrating its pre-Republican manifestation it inverts its history. Moreover, recreating Ottoman cosmopolitanism without its Turkish component is an act of open contestation directed against the former colonial master and current Istanbul majority, the Muslim Turk.

The following section compares Pamuk's and Shafak's binary representations of Istanbul, starting from the assumption that Café Kundera is discursively similar to Pamuk's overground city, the same being true for Café Constantinopolis and the underground city. These spatial representations play a crucial role in the discussion of larger dichotomies I identified as prominent in depictions of Istanbul in The Black Book and The Bastard, namely, imitation and truthfulness, authenticity and Americanization, segregation and integration. The comparison between Pamuk and Shafak will demonstrate that while Pamuk's spaces remain dichotomous, eschewing occasions for reconciliation, in Shafak the two cafés eventually open up to the influence of the Other, foreshadowing the development of hybrid sensitivities.

\section{Becoming Someone Else: Imitation and Truthfulness}

The Black Book's surface city and Café Kundera in The Bastard of Istanbul are pervaded by feelings of uncertainty, displacement, and alienation that ensued from the abrupt change in identitarian narratives enforced by Kemalism. In her analysis of identity construction in Istanbul, Amy Mills notes that "in spite of the fact that the Turkish state has not historically been (nor is it today) a monolithic, 
unchanging entity," Istanbulites perceive the state and state-authored narratives "to have a reality and coherence" (Mills 384). This creates a rupture between the centuries-old multicultural texture of everyday life in Istanbul and hegemonic identity discourses that privilege a less diversified Turkish-Muslim identity. This clash between urban and state narratives is at the basis of the displacement felt by Pamuk's Turkish characters - who are constantly under the impression that they should aspire to be someone else - and of the disharmony that permeates Café Kundera in The Bastard of Istanbul. The following section will compare the ways in which the two novels express the desire to 'become someone else', focusing on how they "emplace" aspects of the search for Turkish identity through the construction of imaginary spaces.

In The Black Book, the surface city hosts a culture of imitation. For the Turkish characters, imitation goes hand in hand with cultural amnesia as if in a vicious circle: Turks imitate Western habits, clothing, and gestures because they conformed to new identitarian narratives that erased their Ottoman, Eastern culture, and vice versa, they have taken on imitating "the European models to which [they] were meant to aspire" so passionately that they cannot remember their original identity any longer (61). Amnesia and erasure, in fact, play a significant role in the construction of Turkey's modern self: "ideas of what it means to be Turkish," Mills explains, "are [...] created through actions to remember and to forget particular histories" (Mills, 386).

The novels repeatedly connects imitation with life in the overground city. In the chapter called "Bedii Usta's Children," one shopkeeper explains that what drives Turkish fashion is the aspiration to resemble "new beautiful creature[s] from a distant unknown land":

"[the customer] is not going to wear a coat he sees worn by someone who looks like the swarthy, bow-legged, mustachioed countryman he sees ten thousand times a day in our city's streets. He wants a coat worn by a new beautiful creature from a distant unknown land, so he can convince himself than he, too, can change, become someone new, just by putting on this coat [...]." What brought them into his store was the dream of becoming "the others" who'd worn that dress. (61)

Political scientist Kürşad Ertuğrul observes that Pamuk’s subject simultaneously casts the Western individual as an "ideal form" and target of envy (Ertuğrul 642). The constitution of Turkey's modern self in Pamuk, Ertuğrul continues, is possible "only through becoming 'someone else," a process that "coincides with a full replication/emulation of 'Western individuality"' (ibid.). By the same token, the realization of this modern self implies the "disavowal of the image of Turkish people's Eastern social and cultural life" (ibid.). In this chapter of the novel, 
columnist Celâl writes of a mannequin atelier which went bankrupt because its creations were too representative of "the real Turk" (61) to be taken seriously in a culture systematically oriented towards Westernization. The passage explains the situation on the surface, which compelled Master Bedii to move his bankrupt atelier to a basement where he continued his profession "until the day he died" (ibid.). The translocation of the atelier to a basement comments on the relevance of underground structures, which receive what has been rejected by the Westernized culture on the surface. The desire to become "the others," "the European models," "a beautiful creature from a distant unknown land" (ibid.) is a peculiarity of overground Istanbul, where "everything was a copy of something else, where people were at once themselves and their own imitation" (165). The surface is populated by "amnesiac" citizens "long resigned to the certainty that their memories would never return to them," irremediably detached from what Celâl calls "inner essence," "innocence," and "true identity" (61).

Similar to Istanbul in The Black Book, Cafe Kundera in The Bastard of Istanbul is a space that visualizes the impact of the Western literary canon on Turkish everyday life and sensitivity.

Cafe Kundera was a small coffee shop on a narrow, snaky street on the European side of Istanbul. [...] How and why it was named after the famous author, nobody knew for sure - a lack of knowledge magnified by the fact that there was nothing, literally nothing, inside the place reminiscent of either Milan Kundera or any one of his novels. (Shafak, The Bastard, 75)

Turkish identity appears to be compromised by the constant comparison imposed on Turkish citizens between their own civilization and the West, by the imposition of European literature and culture as role models, and by the Kemalist predilection of Western aesthetics over the ones deriving from Turkey's imperial tradition. Milan Kundera, a naturalized French author of Czech origin, is a figure from the margins of Europe who became part of the Western literary canon. In the context of Shafak's Istanbul - Café Kundera in particular - this author symbolizes the aspiration to participate in the Western imagination and cultural world. Rumor has it, explains the narrator of The Bastard of Istanbul, that Kundera started to write about the little bar in Istanbul, eventually abandoning the project for more important commitments. "Ever since then, the customers and waiters in Café Kundera had been struggling with a sense of void, digging away at disconsolate futuristic scenarios, grimacing over Turkish coffee served in espresso cups, waiting for a purpose in some highbrow drama wherein they would play the leading role" (78). The "sense of void" that haunts Café Kundera's regulars, the perceived fictitiousness of their existence, and the contemplation of 
"disconsolate futuristic scenarios" liken them to Pamuk's Istanbulites and indicate that they, too, aspire to other lives and other identities for themselves.

In another passage, Café Kundera is described as "a figment of [Kundera's] flawed imagination [...] a fictive place with fictive people as regulars" (77). This image evokes strong connections to Pamuk's text. In The Black Book, an old journalist "came to identify with [the narrator of Proust's À la recherche $d u$ temps perdu] so deeply that he came to believe he was Proust himself; [...] he went from loving Proust's words to believing he himself had written them" (Pamuk 175). In The Black Book, the eagerness not merely to consume but also to become Western cultural products also affects a crowd emerging from a movie theatre:

They were here, on this wretched street, but at the same time they were there, inside the story they'd so eagerly given themselves over. They had gone into the theater with minds sucked dry by pain and defeat, but now their minds were full again with this rich story that gave meaning to their memories and their melancholy. They can believe they are someone else! (Pamuk, The Black Book 222)

The passage reminds the reader of Café Kundera’s guests, "waiting for a purpose in some highbrow drama" (Shafak 78), while Pamuk's film audience would "eagerly [give] themselves over" to a "rich story" that may fill their life with new meaning.

Although the walls of Café Kundera are physically present and delimit an existing space, they are rendered permeable and transparent by the numerous pictures covering them:

on four sides there were hundreds of frames. The whole place gave the impression of being erected on frames instead of brick. In all the frames without exception shone the image of a road. Wide motorways in America, endless highways in Australia, busy autobahns in Germany, glitzy boulevards in Paris, crammed side streets in Rome, narrow paths in Machu Picchu, forgotten caravan routes in North Africa, and maps of the ancient trade routes along the Silk Road, following the footsteps of Marco Polo - there were road pictures from all around the world. (76)

The numberless photographs, paintings and sketches hanging on the cafés walls represent landscapes from all over the world, with the West figuring prominently along with exotic locations. The peculiar furnishing puts the café itself and its customers in the ambivalent position of being present without actually being there: "customers would pick a frame, $[\ldots]$ gaze on the chosen picture, little by little taking off to that faraway land, craving to be somewhere in there, anywhere but here" (77). Similar to Pamuk's film audience, "they were here, [...] but at the same time they were there" (Black Book 222). The café meets the needs of those who long to disconnect from their own city, culture, and territory. If Pamuk's 
characters are obsessed with being someone else, Café Kundera's regular customers harbor escapist fantasies and long to be somewhere else, leading a different life.

The futile search for the reason behind the cafe's name finds multiple correspondences in The Black Book. It recalls Galip's endless search for the meaning of things, which Ian Almond ultimately identifies as the search for national and, above all, individual identity. One of the most striking similarities is the apparently irretrievable connection between words and objects, causing characters to venture into pointless searches for meaning. For example, the discrepancy between the nicknames of Café Kundera's regulars and their professions contributes to exacerbate the "farcical disharmony" (201) of their condition. For example, a character ironically nicknamed the "Nonnationalist Scenarist of Ultranationalist movies" is "a nationalist by profession but a true nihilist by choice" (Shafak 79). The "Closeted-Gay Columnist" is infatuated with another regular client but "the thought of him naked sent shivers down his spine" (80). The "Exceptionally Untalented Poet" dispenses most banal and worn-out poetic images (81).

Some considerations on language formulated by the Armenian American protagonist Armanoush during her visit to Istanbul offer further evidence that, in the imaginary universe of Café Kundera, words, meanings and objects are drifting apart.

They seemed to have no trouble switching from Turkish to English, [...] she suspected that the facilitating factor might be less their confidence in their English than their lack of confidence in any language whatsoever. They acted and talked as if no matter what they said or how they said it, one could not really fully express the innermost self and, in the end, language was only a reeking carcass of hollow words rotten inside. (202)

Once again, after reading about the loss of meaning and the discrepancy between signifier and signified in Pamuk's text, in Shafak one encounters lack of harmony between a national language and its speakers. This concept is complicated, in this case, by the coexistence of two equally ineffective languages, Turkish and English: an overly familiar foreign language and a national language become unfamiliar. The fascination of Pamuk's characters for imitation, resulting in cultural amnesia, is reenacted within Café Kundera's walls. The familiarity binding Turks to English immediately relates to a context of Westernization, or more generally, of English-dominated globalization.

Pamuk's surface Istanbul and Shafak's Café Kundera do not only overlap but also significantly differ. First of all, the pessimism and fatalism pervading the atmosphere of Cafè Kundera is not as endemic as in The Black Book. Café Kundera does not epitomize an irreversible loss of identity and strategies of selfrepresentation. There are in fact alternatives to this displaced, alienated model, 
and, most importantly, Café Kundera is a limited space, not necessarily representative of the city's totality. Evidence comes with the representation of Café Kundera as isolated from the rest of the city, more precisely, "the negation of the whole city" (83):

This place was out of time and space. Istanbul was in a constant hurry and yet at Café Kundera only lethargy prevailed. People outside the cafe stuck to one another to disguise their loneliness, pretending to be far more intimate than they really were, whereas in here it was the opposite, everyone pretending to be far more detached than they really were. This spot was the negation of the whole city. (83)

If Café Kundera is described as a space of immobility, comatose indolence, eternal recurrence, fixations, repetitions, and obsessions $(84,201)$, the city of Istanbul, by contrast, is a fluid, mobile entity: "a city boat," "twisted and multifaceted," a place of "chaos and splendor" $(170,246,143)$. Café Kundera's guests are terrified by the roaring city outside the cafés walls and express their fear through fierce self-criticism, portraying a profoundly divided city, or a city of conflicting identities:

We cannot abandon this rabbit hole for fear of a traumatic encounter with our own culture. Western politicians presume there is a cultural gap between Eastern Civilization and Western Civilization. If it were that simple! The real civilization gap is between the Turks and the Turks. (81)

Considering that Café Kundera is a limited fraction of the city's multifaceted identity, the perspective on the search for Turkey's identity emerging from The Bastard of Istanbul is much brighter than the one dominating The Black Book. Café Kundera embodies the problems of post-Kemalist society highlighted by The Black Book's surface Istanbul, namely alienation, imitation, amnesia, and the desire to be somewhere else (or somebody else). Yet, Shafak's Istanbul is a very lively, cosmopolitan universe that Kemalism could not completely conquer. Shafak's Istanbul - a city of contradictions that contains its own negation and a series of "cities within a city" (181) - exemplifies how "the role of place sometimes supersedes the role of the state in processes of national [...] identity formation" (Mills 386). If on the one hand Pamuk's Istanbul has been completely overcome by amnesia and cultural displacement, Shafak's Istanbul, though partly affected by the same problems, offers strenuous resistance.

\section{'Authenticity' and Americanization}

There is no room for America in The Black Book's construction of Turkish national identity, apart from the role of the neocolonial oppressor, an alien body repeatedly attacked but never truly subverted, imitated but never mimicked. The 
text does problematize and eventually deconstruct the binary division it initially applies to Istanbul. The Black Book's characters long to retrieve the city's prerepublican identity, but they tragically come to the realization that not only will Turkey never recover its primordial self, but that there was never such thing as a Turkish primordial self. By contrast, Shafak transcends the view of America as a destructive intruder; quite to the contrary, America becomes a fundamental component of Turkish identity.

The Black Book indicates that amnesiac and imitative behaviors in Turkey are the result of a "conspiracy" of foreign powers. The first mention of this conspiracy appears in a chapter titled "Do you Remember Me?" where Galip encounters Master Bedii's grandson: "[My grandfather] knew full well what a powerful conspiracy he was up against [...]. These historical powers did not want to give our people the chance to be themselves, and because they wanted to deprive us of the everyday activities and gestures that are our greatest treasure, they kicked my grandfather out of the shops in Beyoğlu" (189). The choice of the term "conspiracy" in reference to Western powers is highly problematic. On the one hand it evokes the late Kemalist mistrust of Europe and the United States for their unrelenting support of Ottoman minorities. In spite of the pro-Western ideology adopted by Kemalism, the Ottoman minorities and the United States were perceived as joined in an alliance against the cause of Turkish sovereignty on the former Ottoman territories, and therefore became the target of resentment and suspicion that have their roots in the "Sèvres syndrome." ${ }^{33}$ On the other hand the hypothesis that The Black Book may support Kemalist ideology is highly unlikely: in both The Black Book and The New Life Kemalism is highlighted as one of the agents of Western imperialism and therefore severely criticized.

If The New Life principally attacks the uncontrolled diffusion of Western commodities and its impact on Turkey's national memory, in The Black Book the popularity of Western commodities - for instance the Western-looking fashion which drove Master Bedii's atelier to the underground - is merely a consequence

43 See Taşpinar, "The Rise of Turkish Gaullism: Getting Turkish American Relationship Right” (2011). Taşpinar investigates the reasons behind the widespread anti-Americanism in Turkey today, and locates the origins of this phenomenon in the post-Sèvres years: "In the eyes of Ankara [...] Washington had become the protector patron of the Kurds. This perception went from bad to worse as Kurds became America's best friend in post-Saddam Iraq and began to pursue a maximalist territorial agenda with claims over Kirkuk. All this proved too much to digest for a Turkish public opinion that had always maintained a heavy dose of fear of disintegration - the Sèvres Syndrome - due to Western support for Kurdish and Armenian nationalism" (3-4). 
of subtle and yet disruptive imperialistic methods. The Black Book concentrates on two modes of diffusion of Western products that greatly affect self-representation and national identity in the surface city: namely, American films and European novels. ${ }^{44}$ An illuminating starting point is again provided by the chapter "Bedii Usta's Children," which has by now proven to be crucial in the discussion of surface versus underground Istanbul in The Black Book. In the following passage, Master Bedii's son recalls how him and his father gradually lost their customers and comes to the realization that cinema was ultimately responsible for Turkey's culture of imitation.

Bedii Usta and his son could not at first figure out whom these people were imitating, whom they had taken as their models for change. Their stock of little everyday gestures was "life's great treasure," but slowly and inexorably, as if in obedience to a secret and invisible master, they were changing, disappearing, and a whole set of new gestures was taking their place. It was while the father and his son were working together on a line of child mannequins that they finally got to the bottom of the mystery. The son cried out, "It's because of those damn films!"(63)

Bedii Usta's son blames the Western film industry in $20^{\text {th }}$-century Turkey for the city's current confusion regarding its own identity. The "secret and invisible master[s]" mentioned in the passage are not the tangible populations of settlers brought to the colonies by Western imperial ventures up to the $20^{\text {th }}$ century, but they are responsible for a more subtle invasion of Turkey by American commodities as well as values, policies, and "large size images" (Sözen in Raw 84). In the following passage the reader learns that, in Master Bedii's son's opinion, films are also the cause for Turkey's loss of sense of Self, for the introduction of "fake, new and ultimately meaningless ways of moving," and for plunging the Istanbul citizenry into a world of constant imitation: "each and everything they did was an imitation" (Pamuk 63).

The most immediate example of cinematographic imitation involves Belkis, an acquaintance of Galip's, who combs "her hair back in the style of Ava Gardner in 55 Days in Peking and paint[s] her lips with the same Supertechnirama red" (210). What appears as an innocent replica of an actress's style is later revealed by the narrator as a masquerade making the woman's face impenetrable and alienated - "He looked at Belkıs again, and it seemed as if she were wearing a mask.

44 Edibe Sözen agrees that films and television were the main vehicles through which American "large size images" were able to spread. See Sözen's “The 'Large Size’ Images in the Americanization Process" (1999). 
If he took that mask by its Supertechnirama lips and pulled it off, he'd have no trouble reading the face underneath" (212).

Films appear in other parts of the text as the cause of unsettling and schizophrenic behaviors. One of the most touching scenes involves a man who sees himself in a film in which he had played an extra. He is delighted by the realization that the man on the screen, although being himself, looks like somebody else, somebody who represents an ideal the man aspires to. The man lingers in this "dreamlike substitution" (171), eventually spending his entire life trying to "catch another glimpse of himself," namely of an unreal, cinematographic self. His delusion is justified by the nature of the culture in which he lives, where it is extremely common "for a man to pass himself off as someone else" (ibid.). ${ }^{45}$

In The Bastard, the U.S. appears as the ideal destination that allows Turkish characters to escape the present, rid themselves of the burden of the past, or shed their national identity. This is evident in the experience of two male characters in the novel: Mustafa, Asya's father, and Barsam, Armanoush's father. Mustafa is the only male member of the Kazanc1 family, which is burdened by a curse that kills its male representatives ahead of their time. As the only man in the family, Mustafa is overly admired and cherished by his female relatives, who bestow their undivided attention upon him. Nevertheless, he feels excluded from the "dark and complicated world" that the women of his family share and this situation causes him to grow into a "narcissistic and insecure" adult (45). When Mustafa reaches puberty, he gives vent to his unexpressed, uncomprehended sexual desire by raping his sister Zeliha and fathering Asya. A few years later, Mustafa decides to run away from his family and from what his shameful past by moving to the United States.

Initially, Mustafa's perception of America coalesces with his frustrated sexuality: "terrified that he would be rejected [...] he turned to yearning for the female body from a distance. This year he had looked angrily at the photos of top models in glossy American magazines, as if to absorb the excruciating fact that no woman this perfect will ever desire him" (44). Mustafa embodies the ambivalent relationship with the West that emerged as a result of Turkish nationalism, within which the West is, to put it with Banu Helvacioğlu, "both the

45 The use of the term "to pass" recalls the phenomenon of 'passing,' which applies to people of color with extremely light skin who pass as members of the white majority and hope for their blackness to remain undetected. Even in the Turkish context, the term is not completely devoid of racial implications. In fact, in this case a Turkish citizen of unspecified ethnicity attempts to pass as one of the probably white(r) actors in an international film production. 
enemy and the object of desire" (Helvacioğlu, "Allahu Ekber" 518). "The same logic," Helvacioğlu continues, "manifests itself in objects of desire and in objects of hatred such as 'women' in patriarchal discourse" (ibid.). In Mustafa's experience, sexual desire and the fascination for America are irremediably entangled. Indicatively, he does not long for local beauties but for top models in American magazines: the longing for a female body, articulated "from a distance," corresponds to the longing for the culture within which these bodies are positioned and imagined, namely, the United States. For Mustafa, the impossibility to possess the object of desire results in the excruciating awareness of the impossibility to own, possess, and participate in American culture. Mustafa creates an evident parallel with Turkish characters in The Black Book, who desperately strive to partake in the culture portrayed by American films and Western novels, which remains unattainable.

Mustafa's choice to move to the United States, however, is mostly motivated by the desire to annihilate his past: "Mustafa knew," the narrator explains, "he had to make it in America not because he wanted to attain a better future but because he had to dispose of his past" (45). In fact, America offers Mustafa a significant help in disposing of the past, facilitating his transition into another life. America, for Mustafa, is a space where his past can be un-written, where he can 'become someone else': "a foreigner with no ancestors, a man with no boyhood," with "no native soil to return to, or [...] memories to recall" (284). His goal is to assimilate completely and cancel every trace of his Turkishness: "One day, Mustafa thought, I will speak in such a way that no one [...] will [...] believe, even for a minute, that they are talking to a foreigner" (45). In Arizona, Mustafa marries an American woman (Rose, Armanoush's mother) and makes America "his home [...] a home with its backdoor closed to the past" (284). It is legitimate to argue that Mustafa is a product of Kemalism: the perfect example of the "nation of forgetters" that evolved as a consequence of the nationalist project in Turkey (Helvacioğlu 505). Through the figure of Mustafa, Shafak suggests that the enforcement of a "voluntary amnesia" or a "historical amnesia" (ibid.) unleashed by the Kemalist regime impacted not only national history but individual histories as well, influencing how single citizens perceive their own past. Armanoush's Armenian American father, Barsam, finds himself in a comparable situation. "All he really wanted was to be like them, nothing more, nothing less, to be American and to get rid of his Armenian dark skin [...] he wanted to be just as white as them. [...] Barsam Tchakhmakhchian couldn't help but feel guilty for rapidly unlearning what little Armenian he had learned as a child" (278). Like Mustafa, Barsam is aware of his diversity and ashamed of it. 
Similar to the inhabitants of Pamuk's overground city, Mustafa and Barsam strive to find their identity through a process of erasure and imitation. By trying to erase their past and imitating American accent, ways, and habits, they hope to unburden themselves of their own personal and national histories and 'become someone else.' It is not by mere coincidence that characters in The Bastard who cannot reconcile their heritage and their present are the fathers of the two female protagonists: Asya and Armanoush.

Differently from their fathers, Asya and Armanoush operate a successful synthesis of Turkishness and Americanness that is based neither on erasure nor on imitation. When she comments on the Turkish version of "The Apprentice,"46 Asya accuses the show of being a "baseless Turkish imitation of America" and adds that "you should amalgamate the technical material borrowed from the West with the particular features of the culture you address. That's what I call a Donald Trump ingeniously alla turca" (153). Asya vehemently attacks the culture of imitation Turkey has produced and suggests it should be replaced by a concept of amalgamation.

The case of Armanoush is even more significant as it inverts the trope of the journey to America as a trajectory of forgetting. Instead of travelling to America to forget her roots, Armanoush feels she needs to leave America to discover them. "Plurality means the state of being more than one. But that was not the case with me. I've never been able to become an Armenian in the first place," Armanoush confesses to the other members of Café Constantinopolis, "I need to find my identity. You know what I've been secretly contemplating? Going to visit my family's house in Turkey" (116). Contrary to her father Barsam, who longs to be American "like everybody else" (278), Armanoush takes the journey to Turkey for the sake of becoming plural. While Mustafa travels to America to erase his past and Barsam wishes he could rid himself of his "Armenian dark skin" (278), Armanoush travels into the past to fully understand her Armenianness: "to be able to become an Armenian American [...] I need to find my Armenianness first. If this requires a voyage into the past, so be it" (118).

In her 2006 article "The De-feminization of Turkish Culture," Shafak announces that "Turkish society and culture have gradually and systematically de-feminized over the last ten decades." The process, Shafak adds, "has reached a climax during the 1930s and 1940s and did not lose its impetus until quite

46 "The Apprentice" is a U.S. reality show hosted by Donald Trump and broadcast on NBC. The show began in 2004 and has been running for several seasons. Adaptations of "The Apprentice" have been aired worldwide. The Turkish version of "The Apprentice" is titled "Çırak" and hosted by Tuncay Özilhan, the CEO of Anadolu Group. 
recently" (Shafak n.p.). Shafak also claims that the 1980s and 1990s reversed the process and, today, "a re-feminization of Turkish culture is well under-way" (ibid.). In her article, Shafak does not go into details as to what this process of re-feminization entails, but surely The Bastard contributes to this discourse. The novel suggests that the construction of Turkish identity may now be in the hands of women and hybrid subjects that substitute imitation with amalgamation and amnesia with the awareness of one's own past. Asya and Armanoush's experience also demonstrates that Turkey's dichotomous selves can and should be amalgamated to obtain a more complex understanding of the homeland, one that integrates a plurality of histories and voices.

\section{Integration and Segregation: Shall the Twain Meet?}

In both The New Life and The Black Book, the alienated Turkish civilization nurtures the hope for revenge. The New Life openly refers to the West as the object of such revenge:

Today we are altogether defeated [...]. The West has swallowed us up, trampled on us in passing. They have invaded us down to our soup, our candy, our underpants; they have finished us off. But someday, someday perhaps a thousand years from now, we will avenge ourselves; we will bring an end to this conspiracy by taking them out of our soup, our chewing gum, our souls. (Pamuk, The New Life 291)

The vagueness of this imperialist opponent, the inscrutable nature of this "conspiracy," and the hopelessly theoretical quality ("maybe in a thousand years") of such revenge, sharpens the feeling that this character might be raging against windmills. In spite of its visionary vehemence, the revenge of the conquered Turkish civilization, deprived of its "soul," still emerges as the vain effort of a helpless civilization, manifesting itself in all its fragility and decay.

The revenge of the underground civilization in the The Black Book is by no means more convincing. Differently from The New Life, The Black Book portrays the effects of a reversal that would bring the underground city to the surface again: this implies that the underground, as a set of removed cultural traditions, would be reintegrated into the collective consciousness. The first revenge scenario is described by Master Bedii's grandson in the basement atelier, who, in one of the previous quotes, prophesized that the underground city would ultimately "[wreak] revenge on the overground city that had supplanted it" (The Black Book 191). The effects would be the following:

on a warm summer day, when all of overground Istanbul was roasting in the sun, dozing amid flies, piles of garbage, and clouds of dust, the skeletons that had been waiting so patiently in these dark and mildewed passages would start to twitch and come to life, and 
there would follow a great celebration, a blessing of life and death that took them beyond time, history and the rule of law. [...] Galip [...] could already imagine the mannequins and the skeletons dancing, and the music fading into silence, and the silence giving way to the clack of copulating bones. (193)

This projection of vengeance, described by the guide as his and his father's "greatest dream" (ibid.) evokes the resurrection of Turkey's submerged heritage, embodied by the skeletons of the ancestors that have been accumulating in the underground passages through the centuries. Nevertheless, the reawakening of an oppressed civilization, against all possible expectations, could not be less appealing. The perspective of an underground renaissance, conducing to the reintegration of Turkey's variegated cultural traditions and the demise of the imitative culture derived from Western imperialism, is portrayed in the novel as a summer apocalypse of dancing and copulating skeletons.

The image of a dried-up Bosphorus - the second revenge scenario - appears in the second chapter of the book, when the dualism between surface and underground Istanbul has not been sketched in its entirety. What can already be perceived at this stage is the revelation of an underground (underwater, in this case) universe that has been gathering all kinds of cultural testimonies, all kinds of objects belonging to various dominations and historical periods that have been amassed side by side for centuries.

On the one hand, the scenario is enthusiastically described as the beginning of a "new civilization" (Pamuk, Black Book 17) where the Ottoman and Islamic heritage, the Republic, and the products of Western contamination coexist. American transatlantic liners lie next to old city ferries, and ancient galleons (17), Byzantine treasures next to knives, forks and soda bottles, skeletons gape "in deference to unknown gods of prehistory" (17) next to dervish lodges and mosques. The privileged ${ }^{47}$ memento in this unseemly 'museum' is a Cadillac a local gangster and his lover committed suicide on by driving into the water, surrounded by skeletons of Crusaders. On the other hand, the view is an extremely discomforting "doomsday chaos" (17) similar to the vision of dancing skeletons. The potentially empowering vision of a coexistence of Turkey's various cultural components - so alien to the modern republican ideologists and so dear to Shafak - is depicted instead in apocalyptic terms: "what is beyond doubt is that the heavenly place we once knew as the Bosphorus will soon become a pitch-black bog, glistening with muddy shipwrecks baring their shiny teeth like ghosts" (16).

47 "Among the drying Bosphorus's revealed artifacts, [Celâl] privileges an immense car, a 'Black Cadillac [...]"' (Komins 377, emphasis added). 
The centrality of the American element in this remarkable passage of the novel has been addressed by Benton Jay Komins in his 2002 essay "Cosmopolitanism Depopulated: The Cultures of Integration, Concealment, and Evacuation in Istanbul." Komins suggests that the Cadillac story, reported in one of Celâl's columns, is the only element that manages to stir Celâl's feeling, whereas he writes about remnants of the Ottoman and pre-Ottoman imperial antiquity with indifference. "In a way, history collapses around this Hollywood image of ultraluxe cars, Bonnie and Clyde-like adventure, and quite fatal romance," writes Komins, while "the residue of Byzantium, the Crusader Kingdom, the Ottoman empire, and even the Republic" are mentioned in passing and abandoned "on the swampy bed of the Bosphorus as meaningless souvenirs of the city's past" (Komins 379).

The two dystopian situations in which underground Istanbul takes its revenge on the surface civilization offer a relevant contribution to the search for Turkey's identity. The solution to this dichotomy seems to be the ultimate reconciliation of the two sides of the city. Yet, it is my contention that The Black Book challenges the myth of the balancing of the extremes by representing such reunion as no solution at all. Initially the novel seemed to express the urge for the recognition of Turkish identity as a hybrid composition, integrating all the cultural elements that determined its history. Yet, if the emergence of a hybrid, cumulative Turkishness could at first seem to offer a solution to Istanbul's (and Turkey's) culture of imitation, the text ultimately shows that, were this solution to be finally enacted, the result would be far worse than the problem itself: a pitch-black, doomsday chaos of dancing skeletons.

If the text ultimately dismisses an integrative vision of Turkish culture, it equally deconstructs the idea of cultural authenticity. Two quotes illustrate how Galip and Celâl try to reconstruct an age of cultural integrity.

Once upon a time, they all lived together, and their lives had had meaning, but then, for some unknown reasons, they had lost their meaning, just as they'd also lost their memories. (194)

Celâl introduces this idyllic situation in which "they all lived together" with a formulaic incipit, "once upon a time," which immediately locates this scenario outside history, in an undefined, fairytale timelessness suggesting the a-historical nature of this fabled age of integrity. The refusal to identify the historical events that may have determined Turkey's collective memory loss, and the lack of interest in doing so, betrays a dogmatic social trauma from which no way out can be found. In this second quote, instead, the narrator refers to a poem celebrating the $17^{\text {th }}$ century as an Edenic époque. 
In the poem's distant golden age, action and meaning where one and the same. Heaven was on earth, and the things we kept in our houses were one with our dreams. Those were happy, happy days when everything we held in our hands - out tools, our cups, our daggers, our pens - was but an extension of our soul. (301)

Not only does the scenario describe the unity between men and their language, language and meaning, but also between heaven and earth. This blatant romanticization of the Ottoman Empire and the ironic undertones of the passage betray a fundamental skepticism towards the myth of Ottoman classical age as a Golden Age. At this point, the text deconstructs the two main ideas on which the underground civilization is based: authenticity and hybridity, invalidating the two major paths towards the assessment of a modern Turkish identity beyond the mystifications of Kemalism and Americanization.

Having abandoned these two options, the text retreats into the fatalism and sadness so aptly described by Ian Almond: "the sadness inherent in The Black Book is not simply of having lost one's national identity to the cultural and economic centers of North America and Europe, but rather the melancholy impossibility of ever having an authentic identity at all" (Almond 84). By declaring the loss of Turkish memory and identity as definitive, Pamuk's text expresses a very pessimistic assessment of Turkey's identity in a globalized context. The Black Book does not try to relocate Turkey in a transnational perspective (a concern that permeates, instead, The Bastard) nor does it make an effort to constructively integrate the Western cultural element in modern Turkish culture. The book laments the overwhelming impact Western aesthetics, especially American movies, had on the Istanbulites' self-perception, without trying to subvert it. Ultimately, Galip's concern is not merely finding his missing wife and brother-in-law; what has been truly lost in The Black Book is the identity of the Self and the nation. As Almond remarks: "this loss of identity is [...] not just the death of the self, but of the collectivity to which it belongs" (82). Almond also points out that national identity has been lost "to something else," namely "to the cultural and economic centers of North America and Europe" (84).

In contrast to the The Black Book, encounters between antithetical worlds in The Bastard yield very productive results. When a member of Café Constantinopolis enters the safe space of Café Kundera and vice versa, they initiate a debate that will lead the characters to question the validity of their assumptions and eventually open up to the perspective of the Other. Thus, in The Bastard, the two oppositional city spaces converge and mingle, enabling change and integration. Differently from Pamuk, the reconciliation of antipodal understandings of Turkishness is not only possible, but strongly encouraged. While The Black Book 
eventually dismisses all the possibilities of identity re-construction it proposes, leaving skepticism as the only option, Shafak addresses the themes of integration and coexistence with serene confidence.

In-betweenness, synthesis, and integration are ubiquitous themes in Shafak's novels. Many of her characters live suspended between two or more realities, unable or unwilling to elect one of these as their prior space of belonging. In one of her newspaper articles Shafak asks her readers:

Who exactly are the Turks? Are we a Western society and if so, why do the Europeans treat us like a different species? Are we Middle Easterners and if so, why do we feel so aloof to their ways? Are we the symbol of "in-between-dom" and if so, in today's increasingly polarized world is it possible to take up one's abode in a threshold? (Shafak, "Making Sense of Irrationality" n.p.)

Shafak's predilection for these themes should not be regarded as particularly idiosyncratic, as the celebration of in-betweennes is deeply rooted in neo-Ottomanist rhetoric. According to Lerna Yanrk, discourses of liminality and hybridity have concurred to create a sense of national exceptionalism from the post-Cold War period until today. Among the most prominent advocates of this discourse, Yanik mentions prominent neo-Ottomanist leaders such as Turgut Özal, Ahmet Davutoğlu, and Abdullah Gül. Yanık argues that, from its origins, neo-Ottomanism has capitalized on "hybrid representations of geography and history," grounding Turkey's identity in its liminality, in "the state of 'being neither here nor there' or "being betwixt and between [...] positions"' (Yanık 80-81). The emphasis on "liminality" and the "hybridization of [...] the Turkish past, especially its multiethnic and multireligious past" contributed to the creation of what Yanik's article addresses as "Turkish Exceptionalism” (ibid.).

Interestingly enough, Café Kundera's regulars feel that in-betweenness is a completely unprofitable situation. The cafés guests discuss two kinds of in-betweenness - geographical and political - and address both in a critical manner:

"We are stuck. We are stuck between the East and the West. Between the past and the future. On the one hand there are secular modernists, so proud of the regime they constructed, you cannot breathe a critical word. [...] On the other hand there are the conventional traditionalists, so infatuated with the Ottoman past, you cannot breathe a critical word. [...] Sandwiched between the two sides, we march two steps forward and one step backward." (82)

"Yeah, we should all line up along the Bosphorus bridge and puff as hard as we can to shove this city in the direction of the West, if it doesn't work, we'll try the other way, see if we can veer it to the East." He chuckled. "It's no good to be in between. International politics does not appreciate ambiguity." (145) 
Not willing to adhere to a particular political current, nor to choose between the East and the West, the "nihilists, pessimists and anarchists" of Café Kundera see themselves as doomed to extinction (82). Taking into account that other novels by Shafak celebrate the condition of in-betweenness as a legitimate place of belonging ${ }^{48}$ Café Kundera constitutes a dissonant note. Café Kundera’s guests fail to understand the constructive potential of in-betweenness, and fail to see its qualities as a foundational value of Turkishness. For them, in-betweenness is rather a condition from which one must urgently move away, as it would lead towards extinction and self-annihilation. This does not come as a surprise when one considers that Café Kundera is a strictly mono-ethnic space that shows very little openness to cultural diversity, as will become clear during Armanoush's visit. Florian Sedlmeier argues, in fact, that "in-between positions have been perceived as precarious because the idea of mixture is inextricably bound up with a discourse of contamination," or even with the "tragedy of not-belonging" (Sedlmeier 9). The dominant discourse in Café Kundera is, therefore, clearly one of cultural segregation and fixity.

By portraying Café Kundera's guests as preoccupied by Turkey's in-betweenness, Shafak condemns some of the discourses circulating in Turkey focused on binary distinctions and fear of diversity. Similarly, she highlights the stark contrast between such discourses and the fluid quality of the city of Istanbul, as the following quote, drawn from one of Shafak's newspaper articles, demonstrates:

East and West are often used as if they were mutually exclusive categories - static and eternal. There is, however, one city where you quickly learn to mistrust the two concepts. In Istanbul, you understand, perhaps not intellectually but intuitively, that East and West are ultimately imaginary ideas, ones that can be de-imagined and re-imagined. (Shafak, "Pulled by two Tides" n.p.)

The frustration expressed by Café Kundera's customers at the country's unsafe position between the East and the West and at its internal clashes and binary divisions creates a stark contrast between the café and the city around it, qualifying Café Kundera as indeed the "negation of the whole city" (Shafak 83).

Asya Kazanc1, the Turkish protagonist, is the only habituée of Café Kundera who fully understands the Cafés status as a dissonant and yet crucial component of the chimeric Turkish society. Asya herself embodies many of the aforementioned problems affecting Turkish identity and self-perception, deserving her

48 In The Saint of Incipient Insanities, for example, the protagonist commits suicide on the Bosphorus Bridge to anchor her identity between two continents. The Forty Rules of Love speaks of placelessness in celebratory tones. 
place among the cafés regulars. But she also has the capacity to mediate between the different components of Turkish identity. At first sight, Asya displays all the features of the post-Kemalist Turkish citizen, affected by the consequences of the ruptures enforced by Kemalism. She is a perfect example for the effects of collective amnesia, as she is detached from and uninterested in her own family history as well as her country's. Asya confronts Armanoush on the meaning of history: "what's the use of [history]? Why should I know anything about the past? Memories are too much of a burden" (179). Asya's detachment from her cultural roots is a product of Westernization, as another conversation with Armanoush confirms: “[Asya:] 'We are Western.' [Armanoush:] 'No you're not Western. Turks are Middle Eastern but somehow in constant denial"' (178).

Yet, Asya perceives the constructive potential of Café Kundera and what it symbolizes, discerning how the Café is only a part of a more complex, multifarious whole:

Nothing was done in harmony, and yet in that dissonance there lay an unusual cadence. This is what Asya liked most about the café: its comatose indolence and farcical disharmony. (84)

The group was a self-regulating organism wherein individual differences were displayed but could never take over, as the organism had a life outside and beyond the personalities composing it. Among them Asya Kazançi found inner peace. Café Kundera was her sanctuary. [...] No one forced you to change since human beings where thought to be essentially imperfect and uncorrectable. (Shafak 87)

The instability and disharmony that characterize the café are reminiscent of the fluidity that is proper to Istanbul. If in the first place Asya had defined Café Kundera as the "negation of the whole city" (83), but she also sees the place as a "selfregulating organism wherein individual differences were displayed but could never take over" (ibid.). This last observation establishes a strong connection to other popular constructions of the city of Istanbul as a living entity formed by heterogeneous components (minorities, diverse architectural styles and influences) forming an organic whole. ${ }^{49}$ Café Kundera is therefore the negation of the city and, at the same time, it replicates the city's structure very closely.

One feature of Café Kundera Asya distances herself from is the display of Turkish nationalism, converging mainly in the denial of the Armenian genocide.

49 See Amy Mills's "Narratives in City Landscapes: Cultural Identity in Istanbul" (2005) and "The Place of Locality for Identity in the Nation" (2008). See also Maurice Cerasi's "The Formation of Ottoman House Types: A Comparative Study in Interaction with Neighboring Cultures" (1998). 
The Non Nationalist Scenarist of Ultranationalist Movies denies the genocide in front of Asya's Armenian American cousin Armanoush, triggering Asya's vehement response. The presence of the Other - an Armenian American - disturbs the dynamics of unchallenged sameness permeating the café, causing great unrest. By doing so, Asya exposes the generalized intolerance - if not plain racism that still permeates the café and triggers a profound change that will turn it into a more integrative space. The Scenarist accuses Armenians of having been carried away by collective hysteria, and of having interiorized narratives that have been repeated and handed down until they became their reality.

"There is such a thing as collective hysteria. [...] It is a scientifically known fact that collectivities are capable of manipulating their individual member's beliefs, thoughts, and even bodily reactions. You keep hearing a certain story over and over again, and the next thing you know you have internalized the narrative. From that moment on it ceases to be someone else's story. It's not even a story anymore, but reality, your reality!" (211, italics in the original)

Asya promptly turns these two accusations against the Scenarist: "Let me tell you what hysteria is. All those scripts you've penned thus far [...] and once you make it into a TV show and make millions internalize your awful message, it becomes collective hysteria" (211). Asya exposes Turkish nationalism as inconsistent and ephemeral. The Scenarist's opinion about his own scripts shifts in the course of this episode: first he describes them as "historical movies" backed up by "meticulous research" (210), but later he speaks of the same movies as "crap," "just for entertainment" (212). Thus, nationalism emerges as an ideology disowned by its own perpetrators.

The Bastard blames Turkish nationalism for its indifference towards Turkey's past and the ensuing culture of imitation, and it does so more explicitly than The Black Book. What is particularly unacceptable for Asya is the way Turkish nationalism manipulates history through a series of narratives.

"What do we know about 1915? [...] I bet you've read nothing! But you're so convinced. Aren't we just swallowing what's given to us? Capsules of information. Capsules of misinformation. Every day we swallow a handful." (210)

The Scenarist's dismissal of the so-called "premodern era and its premodern tragedies" (211) as not relevant, even damaging, for the image of republican Turkey reminds Asya of her family. The way Asya's aunts encourage the removal of unpleasant moments from the history of their family offers a parallel with the erasure of the Armenian genocide from official Turkish historiography:

"my family is a bunch of clean freaks. Brushing away the dirt and dust of memories! They always talk about the past, but it's a cleansed version of the past. That's the Kazancis' 
technique of copying with problems; if something's nagging you, well, close your eyes, count to ten, wish it never happened, and the next thing you know, it has never happened, hurray! Every day we swallow another capsule of mendacity." (147)

The unspeakable event that triggered this form of ostracism is the rape of Zeliha by her own brother Mustafa. This deed is never addressed in Asya's household for fear of the consequences and, as a result, Asya ignores who her father is. Thus, Asya's ignorance about her past, and her aunts' compliance with it, find a direct correspondence in the rupture between Turkey's republican present and its Ottoman past, suppressed by Kemalism for the fear it could threaten Turkey's selfperception as a Westernized democracy.

In this respect, Café Kundera emerges as a site where the manipulation of history operated by Turkish nationalism and, at a smaller scale, by single individuals and families is exposed and challenged. When the confrontation with the Scenarist occurs, Asya has already come to know her Armenian American cousin Armanoush and her story. Made more confident by her interaction with the imperial Other - the Armenian - Asya is ready to expose hegemonic narratives developed during the Kemalist age as inconsistent and ephemeral, disrupting them in favor of more integrative visions of history, privileging the experiences of the former imperial Other and the relevance of individual narratives. The novel suggests that the new Turkish generations need to elaborate different historical models integrating Turkey's heterogeneous, often contradictory, tendencies. Ultimately, Café Kundera is the arena where nationalist historiography is revised through the agency of characters who are able to see Turkish society as a complex, multilayered construction.

If Café Kundera appears to be in many ways comparable to Pamuk's overground Istanbul, Café Costantinopolis is reminiscent of underground Istanbul - where elements that were ejected from the nationalist projects have reaggregated and formed an alternative civilization. An analysis of Café Constantinopolis appears relevant at this point because the café directly addresses the themes of segregation and integration. In the first place, the section reflects on Armanoush's inner conflict between assimilation into mainstream American culture and adhesion to her father's Armenian tradition. Secondly, Asya's irruption in the anti-Turkish environment of Café Constantinopolis triggers a crisis and a renegotiation of essentialist notions of identity that had until then disabled all chances of dialogue between Turks and Armenians.

Café Constantinopolis was a chat room, or as regulars called it, a cybercafé, initially designed by a bunch of Greek Americans, Sephardim Americans, and Armenian Americans who, other than being New Yorkers, had one fundamental thing in common: They all were the grandchildren of families once based in Istanbul. (112) 
This initial description anticipates the strong claim of rootedness and belonging advanced by Café Constantinopolis's guests. The name itself, whose meaning is, unlike Café Kundera's, very explicit, evokes nostalgia and loyalty for a city whose 'original' form has been resuscitated in a virtual café bearing its name. The cybercafé is therefore an "imaginary community," not only because its members share a mythicized idea of common origins and no face-to-face connection, but especially because the geographical reality it is affiliated with no longer exists and has not existed in a long time. In fact, by referring to their city of origins with the name it bore until 1923, the founders of the online community made a clear statement: they expelled the Turkish-Republican element from the city's identity. ${ }^{50}$ By discriminating against Turkish users in forum discussions and against Turks in general, Café Constantinopolis reconstructs an imaginary Istanbul from which the Turkish and Republican elements have been expunged.

In spite of their antipodal functions in the text, Café Constantinopolis has much in common with Café Kundera. I have already alluded to its importance for the Armenian protagonist, Armanoush, who, similarly to Asya and Café Kundera, considers it her "sanctuary" (87). Café Constantinopolis is a space where Armanoush, a young Armenian American woman born to a family that was decimated by the genocide, negotiates her identity, constantly oscillating between Armenianness and Americanness.

Initially, Armanoush's inner fluctuation between these two cultural poles is one between two irreconcilable extremes allowing no possible mediation. Armanoush's Armenianness is often associated with a "beastly inner self", "a cryptic being in deep slumber" residing in the young woman's most intimate dimension (114). The interaction with Café Constantinopolis's regulars, especially with an Armenian American man called Baron Baghdassarian, awakens Armanoush's ethnic self: "[Baron Baghdassarian] poked that creature with the spear of his words, prodding it until it woke up with a roar and came to light" (115).

By contrast, Armanoush finds the perspective of integrating as a "normal" (116) U.S. citizen to be much more tranquilizing. First of all, her integration would please her American mother, Rose, made "hysterically anti-Armenian" (119) by her unhappy marriage to Armanoush's Armenian father. Secondly, it would pave the way

50 The fictional Café Constantinopolis in The Bastard of Istanbul is modeled on an existing Armenian American online community called "Armenian Forum” (forum.hyeclub. com). Shafak doubtlessly consulted the forum as a source on Armenian American identitarian discourses, as the similarities between ideas and terminology employed by Shafak and the forum users (sometimes completely identical) prove. 
to an uncomplicated relationship with an American boy, Matt, very much encouraged by her mother. Unfortunately, for Café Constantinopolis's regulars, assimilating to Americanness would amount to a betrayal of her Armenian origins. In this respect, one of the cafés members compares the children of expatriates in the United States to the Janissaries under the Ottoman Empire:

the Janissaries were Christian children captured and converted by the Ottoman state with a chance to climb the social ladder at the expense of despising their own people and forgetting their own past. The Janissary's paradox is as relevant today for every minority as it was yesterday. You the child of expatriates! [...] [A]re you going to accept the role of the Janissaries? Will you abandon your community to make peace with the Turks and let them whitewash the past so that, as they say, we can all move forward? (114)

The condition of the modern 'Janissaries' presents the awareness of one's roots as incompatible with Americanness. "Accepting the role of the Jannissaries," in fact, has two separate implications. First, it implies "mak[ing] peace with the Turks" and allow a conclusive settlement on the debate on the genocide. Second, it refers more directly to the condition of Armenian Americans, who, by assimilating to American mainstream culture, perpetuate the Janissary mentality.

The Janissary's paradox is being torn between two clashing states of existence. On the one hand the remnants of the past pile up - a womb of tenderness and sorrow, a sense of injustice and discrimination. On the other hand glimmers the promised future - a shelter decorated with the trimmings and trapping of success, a sense of safety like you have never had before, the comfort of joining the majority and finally being deemed normal. (116)

Café Constantinopolis is therefore a space where Armanoush's conflicting and mutually exclusive personalities are laid bare: on the one hand the urgency to maintain the ties to her father's tradition and act in order to prevent the Armenian genocide from being forgotten, on the other hand the desire to assimilate to the American majority for reasons of personal fulfillment and tranquility.

Like Café Kundera and its regular customers, the Armenian American community of Café Constantinopolis is static, impermeable to change, and at times nationalistic and intolerant. The idea that immigrant communities adhere to an ossified notion of national identity recurs frequently in Shafak's work, especially in The Bastard of Istanbul. When the guests of Café Kundera hear that Armanoush is Armenian American, they cannot contain their surprise, as "Armenian Armenian was no problem - similar culture, similar problems - but Armenians American meant someone who despised the Turks" (208). Shafak suggests that, since Armenian Americans do not inhabit the same territory nor share a physical space with the Turks, they base their prejudice about Turks on "stories they've 
heard from their grandparents or else from one another. And those stories are so terribly heartbreaking $(254) .^{51}$

Shafak's journalistic articles provide further evidence that this assumption is very much part of her understanding and conceptualization of diasporic or immigrant communities:

Turks living in Europe can be far more nationalist, conservative, reactionary and religious than Turks in Turkey. [...] The inflexibility of some Turkish immigrant communities in Europe is related less to their "Turkishness" than to "immigrant psychology." [...] Back home here, within the daily routine of politics, things change and they change fast. "Change" is the underlying motto. Not so much for the immigrant abroad, though. The bigger the need to resist change, the deeper the withdrawal into cocoons - ghettoes of glass. (Shafak, "The Return of the Ghetto" n.p.)

Whether we consider Shafak's portrayal of Turkish immigrants in her newspaper article "The Return of the Ghetto" or her depiction of Armenian American identity in The Bastard of Istanbul, diasporic communities emerge as static and conservative as they are not exposed to the constant changes and developments in their native countries.

At Café Constantinopolis, the legitimate hope that Turkey will recognize the Armenian genocide and apologize officially is entangled with very radical positions against the Turks, sometimes amounting to indiscriminate intolerance against an entire population. The community's radical point of view on Turks emerges most clearly when Armanoush describes her stepfather's family as "ordinary Turks":

"what are you going to talk about with ordinary Turks? [...] Look, even the well-educated are either nationalist or ignorant. Do you think ordinary people would be interested in accepting historical truths? Do you think they're going to say: Oh yeah, we are sorry we deported and massacred you guys and then contentedly denied it all." (118, italics in the text $)^{52}$

51 The alleged difference between national and diasporic communities will be discussed again in Chapter Four ("Ottoman Nature") with regard to the character of Aram, botanic symbolism in The Bastard, and Appiah's concept of rooted cosmopolitanism.

52 This stereotypical vision of the Turk as barbaric and loathsome, unscathed by individual cases of agreeable Turks, finds confirmation in the online forum Shafak used as a reference for Café Constantinopolis. "There is no such thing as the 'best Turk,' a Turk is a Turk [...] Nonetheless, what do you think you are going to accomplish by interacting with 'polite' Turks? [...] Most [...] are just a bunch of primitive beasts, therefore, the so called 'good' Turk is irrelevant" (Posted by "Armenian" in response to "To All Hai Dat Champions and Armenian Turk Lovers" on 24 May 2005). 
The perspectives provided by Café Constantinopolis's community dehumanize Turks and depict Turkey as a reality at war with Armenians. In fact, when Armanoush manifests her intentions to travel to Istanbul and look for her grandmother's house, one of the guests comments: "Wow, you will be our war reporter" (119). Accordingly, Turkey is imagined as a country Armenians could not easily enter, or would do it at the risk of their own safety:

"Wait wait wait", Lady Peacock/Siramark typed in panic. "What the hell do you think you're doing? Are you planning to go to Turkey on your own, did you take leave of your senses? [...] How far do you think you can go with that name on your passport? Why don't you instead directly walk into a police headquarters in Istanbul and get yourself nicely arrested?" (117)

What Shafak posits as the most problematic aspect of the Armenian American online community is a negative identity of the kind James Clifford explores in his 1994 essay "Diasporas." Clifford argues that Jews in America are an example of those "peoples whose sense of identity is centrally defined by collective histories of displacement and violent loss" (Clifford 307). Armenian Americans in The Bastard find themselves in a comparable situation. In Shafak, the common hatred against the Turk and the memory of the genocide seem to provide the basis of the unity among the members of the Armenian American community, as they equalize their "common history and culture" with their "common enemy":

every week they would choose a specific topic of discussion. Though the themes varied greatly, they all tended to revolve around their common history and culture - "common" oftentimes meaning "common enemy": the Turks. Nothing brought people together more swiftly and strongly - though transiently and shakily - than a shared enemy. (113)

The transient nature of this bond is the center of the critique formulated in The Bastard, as the Armenian American online community seem indifferent to the value of their shared Armenian tradition and cultural memory - so much so that the "common enemy" emerges as their primary source of community bonding. The exclusively strong connection between identity and a common enemy, paradoxically enough, results in the annihilation of the efforts made by the Armenian and the international community to encourage the Turkish government to officially acknowledge the Armenian genocide. In fact, when Asya intervenes in Café Constantinopolis to apologize for "her father's crime" (262), the members of the community will try their best to invalidate her apologies, encouraging a conclusive comment by Baron Baghdassarian: "Some among the Armenians in the diaspora would never want the Turks to recognize the genocide. If they do so, they'll pull the rug out from under our feet and take the strongest bond that 
unites us" (263). Earlier in the novel, another Armenian member of the café had affirmed that "for most Armenians in the diaspora, Hai Dat ${ }^{53}$ is the sole psychological anchor that we have in order to sustain an identity" (117). ${ }^{54}$

In The Bastard of Istanbul, Café Kundera and Café Constantinopolis share a similar function: they both isolate critical aspects of a post-Ottoman identity. They represent "[s]afe spaces of the like-minded" (Shafak "Safe Spaces" n.p.), as Shafak herself would call them, as they group individuals who share an essentialist, fundamentalist vision of identity. "The desire for a safe and sterile space of existence," Shafak argues in her article "Safe Spaces of the Like-Minded," "is a flawed approach" (ibid.) in so far as the resistance to diversity leads the guests of the two cafés to a dichotomous vision of the world as divided into fundamentally opposite entities (East and West, Armenians and Turks, minority and majority). The novel shows, instead, that these entities can coexist within the same social model.

Café Kundera's and Café Constantinopolis's intransigent positions are eventually redeemed by the penetration of an alien element in their "safe and sterile space of existence" (Shafak, "Safe Spaces" n.p.): an Armenian American in an exclusively Turkish space, and a Turk in a fundamentally anti-Turkish one. This echoes Shafak's words in "Safe Spaces": "if we are to develop intellectually, spiritually and culturally it can only be with and through 'Others"' (n.p.).

Asya's effort to start a dialogue and acknowledge the legitimacy of the Armenian cause will provoke deep unsettlement and eventually trigger a negotiation of guilt:

53 Or 'Hai Tad': the Armenian cause.

54 From "Forum.hyeclub.com": "I do not want the government of Turkey to 'ever' recognize the Armenian genocide. If it does so, I am confident that the entire Armenian population of the Diaspora will disappear into the pages of history within two or three generations. Unfortunately, for most of our brethren the 'Hai Dat' is the only 'psychological anchor' they have that maintains their Armenian identity" ("Armenian" on 8 December 2004). The same post inspired the Scenarist's point of view on the genocide. The Scenarist says "look, I am very sorry for your family, I offer you my condolences. But you have to understand it was a time of war. People died on both sides. Do you have any idea how many Turks have died in the hands of Armenian rebels? [...] Times were different back then. It was not even a Turkish state back then, it was the Ottoman Empire" (208). These lines resemble a passage from the abovementioned thread on 8 December 2004: "There was a major war and many people died on both sides. Turks suffered just as much as Armenians [...] please allow me to say - I am very sorry that all that stuff happened to you people. I am really, really sorry, but we Turks are different now. Times are different now." 
"Tell me what can I do as an ordinary Turk in this day and age to ease your pain?" Now that was a question hitherto no Turk had asked the Armenians in Café Constantinopolis. [...] Until today Café Constantinopolis' encounter with the Turks had basically been a fuming exchange of slander and soliloquy. This time the tone was radically different. $(261,262)$

Asya talks the members of Café Constantinopolis into acknowledging the difference between individual and state responsibilities, and between the Turkish perpetrators of the genocide and present-day Turks. Moreover, Asya forces the Armenian American online community to admit that some of them are not interested in an official recognition of the genocide by the Turkish government, otherwise they would "pull the rug out from under [their] feet" (263) and thus compromise the most powerful common denominator of Armenian identity.

Asya's endeavors obviously do not result in any conclusive solution to the conflicts between Turks and Armenians, but expose contradictory, problematic aspects of the question, pointing out that both sides are flawed. On the one hand, in fact, the Armenian American online community relies excessively on genocide and cultural hatred against the Turks as founding elements of Armenian identity. ${ }^{55}$ On the other hand, present-day Turks display a tendency towards selective memory and denial of the country's 'unwanted' tradition, and rely on historical narratives the novel presents as biased and propagandistic.

The confrontation with the Armenian genocide forces Asya to identify with the Armenian perception of time, where past and present are continuously intermingled. Asya, who this far had categorically refused to accept the past as part of her own self, is thus forced to accept the crucial role of the family and national history in the shaping of an individual's identity. Thus, on an individual level, she addresses one of the problems that affect her nation deeply: national amnesia. The suffering caused by the detachment from her family history will be the decisive element furthering the dialogue between the two communities:

55 The novel includes a list of elements that make someone 'Armenian,' compiled by an Armenian American member of Café Constantinopolis. The list is meant as a "selfscoring test that measured the degree of one's 'Armenianness"' but contains a series of references to Armenian cultural practices. For example, “you can't help feeling sad when you dance to 'Lorke Lorke, even if the melody is bouncy and you don't understand the lyrics" or "the sound of a duduk sends shivers down your spine and you cannot help wondering how a flute made from an apricot tree can cry so sadly" (114-115). The long list demonstrates that Armenian Americans do have a solid cultural heritage, and their fear of losing group cohesion in case Turkey recognized the Armenian genocide appears therefore as unfounded. 
Yes, perhaps it is exactly my being without a past that will eventually help me to sympathize with your attachment to history. I can recognize the significance of continuity in human memory. I can do that... and I do apologize for the sufferings my ancestors have caused your ancestors. (263)

To conclude this section on segregation and integration, in The Bastard of Istanbul the introduction of an element of Otherness into "safe spaces of the like-minded" helps to challenge essentialist and nationalist understanding of post-Ottoman identity and paves the way towards a hybrid concept of identity. In the case of Armenian Americans, the perspectives that must be overcome include, first, the concept of negative identity, based on a common enemy rather than on a common past; second, a binary mentality creating an irreconcilable distance between "an imaginary us and an imaginary them" (Shafak, "Peddlers" n.p.). In the Turkish case, instead, nationalism is linked to amnesia, imitation, and over-dependence on Western canons of representation. Turkey's "historical amnesia" (Helvacioğlu 504) erased the Armenian genocide as part of a past that needs to be ejected from the national self.

In this context, the comparison between Pamuk's and Shafak's representations of Istanbul reveals a fundamental difference of perspective: on the one hand The Black Book laments the loss of a pre-republican Golden Age that resulted in "emplaced" (Mills 384) Manichean divisions. On the other hand, The Bastard does the opposite by representing loci of cultural essentialism entering a deep crisis and opening up to more fruitful and constructive models of cultural hybridity.

\section{The Ottoman Utopia}

The following section resorts to the construct of utopia to address Shafak's romanticization of the Ottoman Empire. With the term 'Ottoman utopia,' I describe literary (mis-)constructions that overemphasize certain positive aspects of Ottoman society - such as tolerance, multiculturalism, and fruitful exchange among ethnic groups - while downplaying others that would cast a shadow on projections of the Ottoman Empire as a utopian space of peaceful coexistence and intercultural harmony. The Ottoman utopia can productively be read as part of the "post-empire imaginaries" outlined by Barbara Buchenau and Virginia Richter in the eponymous volume Post-Empire Imaginaries? Anglophone Literature, History, and the Demise of Empire. Buchenau and Richter recognize that empires as geopolitical phenomena are a thing of the past, but claim that "as a concept, empire is alive and kicking, precisely in the sense of 'post-empire': standing to historical empires in relation of historical succession and, simultaneously, of supplement and simulation" (xix). This leads to a proliferation of post-empire imaginaries 
that market the empire as "a time of tranquility, order, and elegance, now lost forever," "an image of totality which is placed in an irrecoverable position of alterity" and "an illusory vision of completeness" (ibid.). This does evoke the perfect and irretrievable islands of the utopian tradition, but also applies to Shafak's and Pamuk's projections of the classical age of the Ottoman empire as a utopia and a golden age respectively.

Like all utopian formations, the Ottoman utopia bears a political message: it embodies a critique of Kemalism and, at the same time, it resurrects and advocates Ottoman multiculturalism as one of the ideals that should guide the future of Turkey. The following pages will focus on literary manifestations of the Ottoman utopia in Shafak's The Bastard of Istanbul and her journalistic articles, and compare these with representations of an Ottoman 'Golden Age' in Pamuk's The Black Book. The two constructs share numerous affinities but ultimately serve different purposes and display different perceptions of Turkey's post-Ottoman identity. Shafak's Ottoman utopia conveys a vision of Turkey as predisposed to host a diversified society thanks to centuries of Ottoman cosmopolitanism and as potentially able to harmonize its different ethnic components. By contrast, Pamuk's Golden Age not only laments the loss of cultural integrity but also disables all chances to imagine and conceive such integrity. This chapter will end with a reading of the Ottoman utopia through the lens of postcolonial theory: Stuart Hall's reflections on cultural identity will provide a framework to theorize the discrepancy between Pamuk's and Shafak's approaches, defining the latter as most typical of diasporic writing.

Romanticizations of the Ottoman Empire are not limited to Shafak's work and the term 'Ottoman utopia' can also be employed to delineate a larger phenomenon. Edward Said reluctantly admitted to Ari Shavit of Ha'aretz Magazine that "in a funny sort of way, it worked rather well under the Ottoman Empire, with its millet system. What they had then seems a lot more humane than what we have now" (Said 447). In her 2005 article "Narratives in City Landscapes: Cultural Identity in Istanbul," geographer Amy Mills addresses the ways in which Kemalism imagined narratives of national identity that disavowed the country's imperial history and developed independently from it. She adds, however, that contemporary debates revolve around the resurrection of minority history in the form of new counter-narratives locating the essence of the city, an "imaginary 'real' Istanbul" (458), in its tradition of cosmopolitanism. In Mills' words, "narratives of minority history and of European history are being resurrected in the city with images of tolerance and harmonious multiculturalism" (446). These counter-narratives construct an idealized Ottoman Empire, as they "employ a 
nostalgic language of history to narrate a particular place identity, replacing the tensions of the past and the present with seamless and beautiful images" (458).

Architect Maurice Cerasi describes the Ottoman Empire as one which did not bring a preexistent culture to the invaded territories and therefore imposed none (Cerasi 134), thus minimizing the disruptive potential of its imperialistic enterprise. Cerasi exalts the Ottoman Empire's adoption of "syncretism as a basic cultural attitude" (133) which, "even when in conflict, [gave to all] the sense of belonging to a common culture in daily life" (134). The notion of "Ottoman syncretism" as the integration of heterogeneous artistic contributions from different sources and regions presents Ottoman aesthetics as driven by a principle of amalgamation, suggesting an equally tolerant political establishment.

Other voices confute Ottoman romanticizations of this kind. Even in the classical age of the empire, the Pax Ottomana consisted of immutable religious and ethnic differences among subjects, and an unbridgeable imperial distance between the center and the tribute-paying peripheries, between Muslim and nonMuslim subjects - a category that was accepted and tolerated and yet kept in an invariably subordinate position (Makdisi 771). In “Ottoman Orientalism," Ussama Makdisi explains that non-Muslim subjects were constantly addressed with derogatory terms such as "vermin" and "mice," the very names of minorities were used in a derogatory manner and as synonymous with "scoundrel" or "infidel." This was a common practice even in historical and official documents (Makdisi 775). Referring to the Ottoman Empire as a space of "tolerance and harmonious multiculturalism" (Mills 446) promoting a policy of egalitarianism is therefore, if not incorrect, certainly reductive.

\section{Utopia and Empire}

Utopia is a both a construct and a literary genre (Ricoeur, Lectures 15). The term originated with Thomas More's text Utopia (1516), which depicts a fictional journey to an island that hosts a perfect society. The name of the island derives from its fictional ruler and founder, king Utopus. Utopian society is based on the sharing of goods and private property is not allowed. Utopians lead frugal and industrious lives, dress simply, and hold slaves. Riding the wave of enthusiasm and curiosity about the first voyages to America, More locates the island in the New World. Thus, the novel locates its narrative within a plausible geographical and historical context. The protagonist, Raphael, is a member of Vespucci's crew embarking on a new journey and reaching Utopia's shore. The unfortunate loss of the coordinates that describe Utopia's location exclude the possibility of further journeys to the island: thus, Utopia is destined to remain unreachable. More's 
influential book has given rise to a substantial production of utopian writing that describes perfect imaginary societies. Early representatives of the utopian genre include Tommaso Campanella's The City of the Sun (1602), Francis Bacon's New Atlantis (1627), James Harrington's The Commonwealth of Oceana (1656), and Margaret Cavendish's The Blazing World (1666). Utopian fiction has continued uninterruptedly to this day, when the genre has entered the domain of science fiction. The same is true for the equally popular counterpart of utopian fiction: dystopian fiction, which represents life in utterly undesirable, often postapocalyptic societies. Similar to utopias, dystopias are also profoundly political.

Utopia as a construct remains central to cultural debates worldwide: it is primarily the representation of a perfect society and it expresses the desire for social improvement. Ernst Bloch defines utopias as "dreams of a better life" that manifest the aspiration to the "greatest possible realization of social happiness" (Bloch 3). Another fundamental function of utopia is social criticism. Zygmunt Bauman affirms that "any utopianism worth the name must engage in a significant polemic with the dominant culture" (Bauman 47). Paul Ricoeur describes utopia as "an empty place from which to look at ourselves," from which "an exterior glance is cast on our reality" (Ricoeur 15,16). He sees the utopian imagination as a "process of subversion" through which we put our cultural system "at a distance" and derive the ability to look at it from the outside, from the privileged position of a "nowhere" (17). In short, utopias allow the society that produces them to reflect upon itself, elaborate a critique of the status quo, and propose solutions, visionary as they may be.

Nowadays, pessimism is very prominent in utopian scholarship. "Today the word 'utopia' does not have a good sound to it," Bloch states in a conversation with Theodor Adorno, "is has been depreciated and is used primarily in a negative sense to mean 'utopian"' (Bloch 1). Ricoeur identifies a tendency to read utopia as "schizophrenic": escaping society on the one hand, avoiding any kind of concrete action on the other (Ricoeur 2). "Escape," Ricoeur stresses, is the "pathology of utopia" (17). More recently, Bill Ashcroft has agreed to understand utopia as an inconclusive form of protest. Starting from the assumption that "to achieve utopia is to fail to realize the possibilities of utopia," Ashcroft concludes that "all realized utopias are degenerate" (Ashcroft, "Critical Utopias" 413). Besides being addressed as little more than an escapist fantasy, utopia has been exposed as a potential repository of narratives of nostalgia (Ashcroft 421; Ricoeur 17). As the following section will clarify, the case of Shafak's Ottoman utopia is particularly problematic as it critiques nationalism by evoking an idealized imperial society. The nostalgia for an Arcadian or paradise-like past that informs the Ottoman 
utopia is therefore fraught with imperial nostalgia. Ultimately, utopia remains a space outside of history, a productive nowhere enabling the possibility of social criticism. If the utopian genre began by depicting impossible societies that were far removed from us in terms of space, the nowhere of utopia is now often twice removed. Contemporary utopias in fact are usually future-oriented, as with sci-fi fiction, and the Ottoman utopia presented in this chapter offers, instead, a 'retrospective' example that locates utopia in the past.

Ashcroft ${ }^{56}$ contributes a significant further layer to the scholarly debate on utopia, as he connects utopianism with the postcolonial, identifying the utopian as a "deep and growing aspect of postcolonial literature" (Ashcroft, "The Ambiguous Necessity of Utopia" 9). Ashcroft begins by exposing the imperial project in Thomas More's novel: King Utopus invaded and conquered the land of Abraxa, taught "civil gentleness" to "the rude and wild people" who resided there, and renamed the place after himself (More 123). Utopia was written in the wake of Europe's imperial venture in the New World: the acquisition of Newfoundland in 1583, a few decades after the publication of the book, will mark the rise of the British Empire. For this reason, Ashcroft identifies the notion of utopia as infused, from its origins, with a "deep colonial impulse" and suggests that More unveiled "the ideology of the colonial [...] that lay deep within the English psyche" (Ashcroft, "Critical Utopias" 414). To Ashcroft, influential literary works written in colonial times such as William Shakespeare's The Tempest (1610-11) and Daniel Defoe's Robinson Crusoe (1719) constitute "imperial utopias" due to the strong utopian impetus they present (Ashcroft, "Ambiguous Necessity" 415). However, the utopian instinct is also a crucial aspect of postcolonial rewritings of the same texts and of the postcolonial literary experience in general, as "without utopian thinking liberation is impossible" (Ashcroft, "Necessity" 8). In short, in Ashcroft's analysis the utopian has accompanied the colonial and imperial experiences from their beginnings to their postcolonial aftermaths.

It is possible to productively read Shafak's Ottoman utopia through the lens of Ashcroft's conceptualizations. In Shafak, one often reads of the denaturation of Turkish culture operated by Kemalism, of the introduction of a Western type of ethnocentric nationalism at the expense of Ottoman 'multiculturalism' and 'cosmopolitanism,' of state-enforced national amnesia, and of the alienation that resulted from the imposition of a Western mindset. It can be concluded that the impact of Kemalism in Turkey - at least for Shafak - is not very different from

56 The articles by Ashcroft included in this sessions are "Critical Utopias" (2007), “The Ambiguous Necessity of Utopia” (2009), and "Spaces of Utopia” (2012). 
that of Western colonization elsewhere. If we identify Kemalism as a colonial agent in Shafak's conceptual framework, the Ottoman utopia seems to have much in common with Ashcroft's postcolonial utopias. The compatibility between Ashcroft's model and Shafak's text confirms that the study of Turkish American literature adds further complexity to the postcolonial paradigm. By the same token, applying postcolonial theory to the narratives surrounding Turkey's postimperial present proves to be a fruitful endeavor.

A first correspondence between Ashcroft and Shafak can be found in the resistance postcolonial utopias offer to the concept of nation. Postcolonial utopian thought, writes Ashcroft, "gains much of its character from its problematic relationship with the concept of nation" and "transcends the disappointment and entrapment of the nation-state" (Ashcroft, "Spaces of Utopia" 4). Shafak's utopian vision is invested in demonstrating that the monocultural Kemalist model grates against the multicultural vocation of Ottoman society. This becomes obvious in the passages analyzed in this chapter. For example, in "Life in the Islands," Shafak addresses Turkey's trajectory from "a multilingual, multiethnic, multireligious empire towards a secular, modern nation-state" as "a major transformation unheard of in other regional contexts," but she lingers on the "flipside[s] of this story," namely the "loss of cosmopolitanism" and "collective amnesia" (Shafak, "Islands" n.p.). The utopia of cosmopolitanism embodied by the islands around Istanbul expresses the necessity to move away from this condition and "celebrate, once again, multiculturalism" (ibid.).

Like the postcolonial utopias described by Ashcroft, Shafak's utopia is a combination of time and space, as it appears to be articulated through narratives of memory as well as through narratives of place. With regards to time and memory, Ashcroft's concept of the "myth of return" or "fantasy of unhappening" ("Critical Utopias" 421) is of utmost significance in the reading of Shafak. It expresses "the tendency for postcolonial resistance to gain its energy from a utopian vision located not in the future but in the past": through the myth of return "the past in general and memory in particular become central in postcolonial utopianism" as they are "deployed in literature to reconceive a utopian present" $(420,422)$. As examples for this practice, he mentions Pharaonic Egyptian culture in contemporary African literature and the redeployment of Hindu Myths in Indian writing (423). Shafak's utopian vision strongly relies on Ottoman history: it retrieves the model of a past society and proposes it as a possible future for the nation. Yet, Shafak complicates Ashcroft's myth of return: similar to Ashcroft's postcolonial utopias, Shafak's is also characterized by "a nostalgic memory of the precolonial and a recovery of forgotten history" 
(Ashcroft, "Necessity" 9), but in her case the precolonial coincides with the imperial. The risk of "Arcadian nostalgia" that is intrinsic to the myth of return is, in Shafak, even more problematic as it coincides with imperial nostalgia.

Ashcroft comments on the role space plays in postcolonial utopianism and in the myth of return. "The return to the past," Ashcroft explains, "comes not from the atavistic desire to retrace the path of history, but from an overwhelming concern with place $[\ldots]$. Utopia becomes [...] an attempt to reconceive a place in the present, a place transformed by the infusion of the past" (Ashcroft, "Critical Utopias" 423-4). For Ashcroft, postcolonial utopia features a combination of past and present, of place and time. Shafak's Ottoman utopia is a fitting example for the spatial quality of the myth of return: in Shafak's utopia, the transfusion of the past into the present is articulated in spatial terms and invariably connected to a specific place. The cosmopolitan lifestyle that is the remnant of Ottoman times is "confined to particular spots and those only," namely, the islands and the ferry to the islands, which embody "an ages-old, deeply-rooted cosmopolitan culture and a way of life that Istanbul used to retain once but has long lost" ("Islands": n.p.). When Shafak wishes for the "captivating fabric of life present in the islands" to "recuperate and cascade all over the country," she not only advocates the re-establishment of a past societal model, but also the juxtaposition of a space - the islands - upon another - the country. Consequently, the Ottoman utopia is a strongly "emplaced" phenomenon (Mills 384), even in its American manifestation. Only in the United States can the dispersed minorities of the Ottoman Empire, forced into a diasporic existence, reaggregate, thrive, and communicate in a new lingua franca. Café Constantinopolis itself emerges as a "fantasy of unhappening." The gesture of retrieving the name Istanbul had before 1923 is highly symbolic, as it returns the city to its pre-Republican state, salvaging its multiethnic past and yet removing part of its history. Thus, the fact that Café Constantinopolis is an online platform does not disturb its "emplacedness." On the contrary, it adds further complexity to the discussion of place and exposes the cafés imperfect Ottomanism as, ultimately, a fantasy.

\section{Ottoman Utopia and Neo-Ottomanism ${ }^{57}$}

Elif Shafak's notion of Ottoman utopia is embedded in the Turkish political context of the late $20^{\text {th }}$ century and the beginning of the $21^{\text {st }}$. The Bastard of Istanbul and most of her journalistic production for Turkish Daily News, where

57 See also Furlanetto, “Imagine a Country where We Are All Equal': Imperial Nostalgia and Ottoman Utopia in Contemporary Turkish Literature” (2015). 
the discussion of Ottoman utopia is concentrated, appeared between 2005 and 2007. In 2003, the election of Recep Tayyip Erdoğan coincided with a conspicuous political triumph of the neo-Ottomanist doctrine. Neo-Ottomanism consists of a set of political strategies and a state philosophy that invoke a definitive departure from Kemalism. The term has been used to define the political orientation of Erdoğan's AKP, but a first shift to neo-Ottoman ideas was initiated by Turgut Özal's presidency in the 1990s. The neo-Ottomanist vision implies a re-evaluation of Turkey's imperial past and intends to mitigate the nation's inner conflicts which involve, for example, the claims of former imperial minorities. Instead of repudiating the empire as an age of backwardness and religious obscurantism, neo-Ottomanism treasures its legacy. If Kemalism insisted on assimilating former imperial minorities under the category of 'Turkishness', neo-Ottomanism advocates a more multicultural notion of citizenship. NeoOttomanism aims to balance the extremities of Kemalism on many fronts. If Kemalism had been "over-obsessed with a Western trajectory" (Taşpinar, "The Rise of Turkish Gaullism 2), neo-Ottomanism re-habilitates the imperial and Islamic legacies, and promotes diplomatic relationships with former imperial territories as well as with the United States and Europe.

Being modeled on political neo-Ottomanism, the Ottoman utopia is by no means a reactionary, imperialistic fantasy. As Ömer Taşpinar clarifies, the "neoOttoman paradigm [...] does not pursue a neo-imperialist policy aimed at resurrecting the Ottoman Empire. Instead of imperial nostalgia, neo-Ottomanism is essentially about projecting Turkey's 'soft power' - a bridge between East and West, a Muslim nation, a secular state, a democratic political system, and a capitalistic economic force" (Taşpinar, "Turkey’s Middle East Policies” 3). In the same way, Shafak's texts do not look at the empire as a form of government that could be, or should be, resurrected, but idealize the imperial society as an alternative culture to Kemalism.

Ottoman romanticizations - including Shafak's - nevertheless display an Orientalist quality. One of the common features of Ottoman romanticizations, including Erdoğan's neo-Ottomanism, is the wish to restore the Ottoman model of tolerance and multiculturalism after the nationalistic experience of Kemalism, which is often considered a deviation from Turkey's 'real' multicultural vocation. This process of dissociating a brilliant past from the degenerate present, Ussama Makdisi argues, is at the heart of European Orientalism (Makdisi 782). This finds confirmation in Edward Said, according to whom the Orientalist differentiates between a "good Orient," a long-gone classical period, and a "bad Orient," lingering in present day Asia (Said, Orientalism 99). This combination of criticism 
towards contemporary society and use of the past as a source of inspiration for future developments meets Said's description of the Orientalist mission, according to which the "good Orient" needs to be recreated by scholars and posited as the true classical Orient that could be used to judge and rule the modern Orient (Said 92). This Orientalist mission is very much part of Shafak's Ottoman utopia, which condemns Turkey's modernity as an unfortunate, deviant development and points at the classical age of the Empire as the manifestation of Turkey's true vocation to multiculturalism.

Although there are certainly numerous contact points between the politics of neo-Ottomanism and Shafak's Ottoman utopia, one of the fundamental differences involves the role of the United States. On the one hand, political neoOttomanism - Erdoğan's understanding of it in particular - "others the US and presents the Ottoman Empire as an ideal" (Wigen 6). Erdoğan's rise to power in 2003 coincided with a diffused disenchantment with the United States, due to its policies in Iraq (ibid.); parallel to the Iraq conflict, anti-Americanism became rampant throughout the country. At the same time, neo-Ottomanism constructed Turkey as the ideal mediator between the West and the Middle Eastern powers, and the guarantor of democratization and religious moderation (see Wigen 7). Taşpinar remarks that, ironic as it may seem, AKP policies also exacerbated the Kemalists' disenchantment with the West: the Bush government's appreciative evaluation of Turkey as a model Islamic republic delivered the final blow to the relationship between the Turkish nationalists and America. Narratives of U.S. multiculturalism are otherwise deeply ingrained in Ottoman romanticizations in Shafak's texts and beyond. In "Ottomanism vs. Kemalism: Collective Memory and Cultural Pluralism in 1990s Turkey," political scientist Yilmaz Çolak establishes a connection between the $19^{\text {th }}$-century idea of Ottomanism and the melting pot narrative. According to Çolak, $19^{\text {th }}$-century Ottomanism "served to create a consciousness of being Ottoman through melting various groups into one pot" (Çolak 593), whereas neo-Ottomanism, in his words, had been constructed "as a myth of the melting pot" (ibid.). ${ }^{58}$

58 Maurice Cerasi identifies a potential connection between the Ottoman Empire and the American cultural narrative of the melting pot ex negativo: "All of this was not the outcome of a melting pot. It was rather a process of deliberate selection which adopted or rejected foreign and native factors according to their suitability for the weltanschauung of urban society in general" (Cerasi 149). In spite of the negative nature of the comparison, describing how the syncretism of the Ottoman model should rather not be equated to a melting pot, Cerasi's observation establishes a connection between the two. 
Shafak's Ottoman utopia is not simply the projection of a perfect community, lost in the passage from empire to national state. Shafak sees the Ottoman utopia as a productive social solution that has its roots in the past, but can be successfully re-enacted in the future. In fact, it shows evident similarities to Alison Blunt's concept of productive nostalgia as "longing for home that was embodied and enacted in practice rather than solely in the imagination, $[\ldots]$ oriented towards the future as well as towards the past, and to a sense of place that was both proximate and distant" (Blunt 719). Both Blunt's productive nostalgia and Shafak's Ottoman utopia express not only the longing for a lost world, but also for the retrieval of that lost world and its practical re-enactment. In fact, like other utopian formations, the Ottoman utopia has a political function: it projects a vision of a better society that questions the salient traits of the existing one. It formulates a critique of the persisting legacy of Kemalism, the major political and doctrinal system in Turkey since 1923, and indicates a fully viable alternative model, drawn from Turkey's imperial past. The neo-Ottomanist influence on Ottoman utopia emerges clearly in their shared opposition to Kemalism. If Kemalism categorically dismissed Turkey's imperial legacy and ignored the claims of former imperial minorities, neo-Ottomanism and Shafak's Ottoman utopia promote a re-evaluation of the nation's Islamic past. In spite of its nostalgic and a-historical nature, Ottoman utopia is not merely a literary reverie: my findings so far have shown its political value, determined by its adherence to the neoOttoman doctrine and its critique of Kemalism. This last function in particular shows how Shafak's representation of the Ottoman Empire transcends the nostalgic longing for an imaginary Golden Age and claims its legitimate position in the tradition of utopian thought.

\section{“Hrant Dink's Dream"}

My analysis will now turn to texts where Shafak's Ottoman utopia constructs the Ottoman past as a paradigm that may be re-introduced in the present, both in the private lives of citizens and in the future of the nation as an alternative to Kemalism. The utopias of cosmopolitanism presented in The Bastard of Istanbul and the journalistic article "Hrant Dink's Dream" resonate with American paradigms of multiculturalism: America emerges as a space where Ottoman cosmopolitanism can be effectively re-enacted, but at the same time American multiculturalism should not represent a refuge for Turks or exponents of the minorities who disapprove of the consequences of nationalism in Turkey. As the experience of Aram in The Bastard demonstrates, the Ottoman utopia can and should urgently be implanted in Turkey. 
In The Bastard of Istanbul two Armenian characters, Hovhannes Stamboulian and Aram, express their preference for cosmopolitanism over nationalism and confirm their trust in the Ottoman model:

Hovhannes Stamboulian believed that under the present circumstances Ottomanism was the best option for Armenians, not radical ideas. Turks and Greeks and Armenians had lived together for centuries and still could find a way to coexist under one umbrella. [...] "We need to work together, Jews and Christian and Muslims. Centuries and centuries under the same imperial roof. We have been living together all this time, albeit on unequal ground. Now we can make it fair and just for all, transform this empire together." (232)

[Aram:] "Armenian Istanbulites belong to Istanbul, just like the Turkish, Kurdish, Greek and Jewish Istanbulites do. We have first managed and then badly failed to live together. We cannot fail again." (254)

Shafak's journalistic articles for Turkish Daily News mirror the cosmopolitan ideal advocated in her novel as they voice claims and concerns of Armenians in Turkey. "Hrant Dink's Dream" is a particularly powerful tribute to the late Armenian journalist, his opposition to Turkish nationalism, and his struggle for official recognition of the Armenian genocide. Dink was assassinated in Istanbul in 2007 by a Turkish ultranationalist, and his murder resonated strongly in Shafak's writing. Like Shafak, Dink strongly believed in a possible reconciliation between Armenians and the Turkish state, equally condemning extremisms from both sides.

The article provides one of the most elaborate representations of Ottoman utopia and deserves to be quoted at length.

Imagine an exquisite dinner scene in Istanbul [...]. Inside the room, the variety of the food served reflects the multicultural roots of today's Turkish cuisine: Albanian meatballs, Greek seafood, Kurdish spices, Armenian pastries, Turkish pilaf. People drink and eat and laugh and from time to time they toast friends long departed. Then somebody starts to sing a song. Other guests join in and before you know it a string of songs follow, most of them sad but none disheartening. The songs switch almost effortlessly from Armenian to Kurdish, from Turkish to Greek. Where one stops another one picks up. Imagine, in short, a cosmopolitan setting where everyone is welcome no matter what their ethnicity, race or religion. Imagine a country where we are all equal, friendly and free [...]. [Hrant Dink] made us believe that we, the citizens of modern Turkey, as the grandchildren of the multiethnic, multicultural and multilingual Ottoman Empire, could and should live together without assimilating differences or erasing the memory of the past. [...] Imagine a moment in time when there is no chauvinism, xenophobia or racism. A moment when we are all united in a common spirit. It wasn't a dream. We thousands of Istanbullular saw it happen. (Shafak, "Dream” n.p.) 
This symbolic communal meal at a table where Turks and imperial minorities celebrate their common heritage through the sharing of food and singing is in fact more than a "dream." Peaceful coexistence and the treasuring of common roots are presented as a possible everyday practice for Turks, realizable both in the present and in the future, as the same dynamics that made coexistence possible during the Ottoman Empire can be re-enacted by contemporary Istanbulites: "the grandchildren of the multiethnic, multicultural and multilingual Ottoman Empire." The text suggests that cosmopolitanism and tolerance are embedded in Turkey's past and can therefore be revived. In other words, the solution for Turkey's modern problems - the relationships with former imperial minorities, cultural amnesia, fundamentalisms of all kinds - lies in the imperial past, when diversity was allegedly respected and appreciated. With the statement "we [...] saw it happen," Shafak suggests that coexistence is indeed possible, because it supposedly represented the normality of everyday life in the empire. Thus, the Ottoman utopia re-evaluates the notion of the imperial, shifting the emphasis from oppression to peaceful coexistence.

Even though it is not explicitly included in the dinner scene, the United States plays a fundamental role in this discussion of the Ottoman utopia. In the first place, Shafak's Ottoman utopia is indebted to the American cultural narrative of the melting pot, which celebrates the peaceful coexistence of different ethnic groups within the same national territory as one organic, although internally diversified, culture. The Bastard of Istanbul proposes a vision of America as a place where the Ottoman Golden Age can be recreated. The novel suggests that the United States, due to its constitutional multiculturalism, encouraged the resettlement of former imperial minorities - Armenians, Greeks, Jews, and others - who were compelled to leave their homeland after the empire had collapsed, and Turkey had turned into a modern republic invested in a nationalist project that did not fully include them. Once in the United States, the dispossessed imperial minorities recreated the fruitful interaction that characterized their life in the Ottoman territories, re-aggregating into ethnic communities, renewing and intensifying their dislike of the former imperial conqueror, the Turk, and embarking on their own nationalist projects (see Shafak, "The Return of the Ghetto" n.p.).

With Café Constantinopolis, The Bastard suggests that an 'Ottoman' revival is nowadays fully functioning in the United States. At the same time, Turks and former imperial minorities should urgently work together towards the actuation of an Ottoman utopia in Turkey. The following comparison between passages from The Bastard and "Hrant Dink's Dream" indicates how Aram is in fact a Hrant 
Dink-figure: an allusion, perhaps even a tribute, to the Armenian journalist and his struggle for the rights of minorities.

"If they are oppressing you here, you can always come to America. There are many Armenian communities there who would be more than happy to help you and your family." Aram did not laugh this time. Instead he gave her a warm smile, warm but somewhat tired. "Why would I want to do that, dear Armanoush? This city is my city. I was born and raised in Istanbul. My family history goes back at least five hundred years. (The Bastard 254)

After a lifetime's experience [Dink] could have drawn the conclusion that this country was no place for a minority and gone abroad, where he would most probably be safer and much more comfortable. But he did just the opposite. He had uttermost faith in his fellow citizens and believed that through dialogue and empathy even the most ossified chauvinisms would melt away. (Shafak, "Dream" n.p.)

The Ottoman utopia in Shafak's writing applies to both the American context - where imperial minorities have found a fertile soil to re-enact Ottoman multiculturalism - and to the Turkish one, in need of an alternative political model. In Shafak's view, Café Constantinopolis and Armanoush's confidence in American multiculturalism should serve as an example for Turkey - once the cradle of Ottoman coexistence - to unlock its own potential for multiculturalism. Its capacity to link the United States and Turkey makes the Ottoman utopia a transnational narrative.

\section{Life in the Islands and in the Villages}

Another article from Turkish Daily News, "Life in the Islands" (2006), expands the theme of the Ottoman utopia. The fact that Thomas More's Utopia is also an island is indeed relevant in the analysis of how Shafak's idealizations of the Ottoman Empire connect to the tradition of utopia in literature: the islands around Istanbul represent for Shafak a space where a 'perfect society' - the Ottoman way of life - has survived. This perfect society consists of a sophisticated culture of multilingualism that can be seen and heard in the plurality of languages spoken by the inhabitants.

The islands [Büyükada, Heybeliada, Burgaz and Kınalı] embody an ages-old, deeplyrooted cosmopolitan culture and a way of life that Istanbul too used to retain once but has long lost. There, you will encounter a variety of people, a motley cluster of individuals from all walks of life, and hear a variety of languages and idioms, being spoken all at once. Greek and Jewish, Armenian and French, English and Ladino will intermingle with Turkish. Every now and then you will hear a sentence that had started in Turkish to be completed in Jewish. Sometimes a talk in Turkish will be replete with Armenian expressions. You will hear them all. You will happen upon mothers who speak French with 
their children, Turkish with their husbands. You will see women who enthusiastically, unreservedly and almost endlessly gossip in one particular language, but then choose another language when they want to "get serious." [...] You will pass by mosques and synagogues and churches. (Shafak, "Islands" n.p.)

Similar to More's Utopia, an island whose coordinates have been lost and can therefore never be reached again, the sophisticated culture of which the islands were once only one example has been lost in Turkey's passage from empire to republic, bringing about a homogenization of Ottoman culture as essentially 'Turkish' and secular.

And you will lament the gradual loss of this astonishingly, gracefully intense and vivid cosmopolitan culture, once present in almost every nook and cranny in Istanbul and Turkey, but now confined to particular spots and those only. Turkey has lost countless minorities in its recent history - so many non-Muslim families have left this country, step by step. Though they are gone, from each and every family something remains behind - remnants of a past not that far away. [Turkey] has moved away from being a multilingual, multiethnic, multireligious empire towards a secular, modern nation-state. (“Islands" n.p.)

Ultimately, the islands embody what remains of an Ottoman Golden Age that succumbed to the introduction of Kemalist doctrine, which strove to create a society where all spoke Turkish and identified as Turkish citizens.

In spite of the dramatic tone with which Shafak comments on the loss of "this astonishingly, gracefully intense and vivid cosmopolitan culture," she envisions cosmopolitanism as a cultural model that has not been irremediably lost, and therefore can and must be pursued for the future of Turkey. This bears another connection to the utopian imaginary: according to Louis Marin's interpretation of More's Utopia, "the travel [to Utopia] cannot be repeated, but [Utopia] as an ideology, as an ideological representation, demands to be repeated" (Marin 416). In Shafak, the Ottoman Empire is a thing of the past, but the cultural practices that characterized its classical age need to be retrieved. A perfect embodiment of the Ottoman utopia, the islands stand for both a lost Golden Age and a glorious vision of the future.

An analogous romanticization of the Ottoman Empire, or of a pre-Republican Turkey, can be found in Orhan Pamuk's The Black Book, where the protagonist, Galip, fantasizes about $17^{\text {th }}$-century Hurufi villages. ${ }^{59}$ Not unlike Shafak's islands, Hurufi villages in Pamuk are an exception to the status quo. Fleeing the disorders

59 Hurufism is a version of Sufism $\left(14^{\text {th }}\right.$ and $15^{\text {th }}$ centuries $)$ that envisions the Koran as a Kabalistic system of letters. The name comes from the Arabic "hurufi," meaning letter. 
created by the celâli revolutions ${ }^{60}$ of the early $17^{\text {th }}$ century, the Hurufi adepts "settled in remote villages that the peasants had abandoned, fleeing from the wrath of pashas, judges, bandits, and imams" (301). The Hurufi continued their "happy and meaningful life" (301) in rural areas far removed from the city, where they developed their capacity to read culture and interpret the meaning of things. Galip describes that "distant golden age" of the villages as a time in which

action and meaning were one and the same. Heaven was on earth, and the things we kept in our houses were at one with our dreams. Those were the happy, happy days when everything we held in our hands - our tools, our cups, our daggers, our pens - was but an extension of our soul. A poet could say tree and everyone who heard him would conjure up the same perfect tree - could see the word and the tree it signified, and the garden the tree signified, and the life the garden signified [...]. For words were so close to the things they described that $[\ldots]$ poetry mixed with life and words with the objects they signified. [...] Those were the days when faces, like everything else in the world, were so laden with meaning that even the illiterate - even the man who could not tell an alpha from a piece of fruit, an a from a hat, or an alif from a stick - could read them with ease. (301)

The scenario depicted in the passage describes a Golden Age in opposition to the "dark moment in recent history that some call 'the road to democracy" (307). Such description of Turkey's present appears only a few pages after the description of "those happy, distant, timeless days" (301) that constitute Pamuk's Golden Age - once again creating a contrast between an idealized past and a degenerate present. The representation of Hurufism - banished by the Kemalist regime - as a Golden Age, and of modern-day Turkey as a dark chapter of Turkish history echoes the political function of the Ottoman utopia present in Shafak's texts. Yet, Pamuk's Golden Age lacks the productive quality of Shafak's utopia. While Shafak posits Ottoman multiculturalism as an experience that can and should be repeated, Pamuk's Golden Age is merely a fantasy and a eulogy over a past that is irretrievable. The dreamy, nostalgic tone of the passage causes the reader to doubt the reliability of the narrator and the historicity of the narrated facts. Hyperboles ("everything else in the world," "everyone") and statements such as "heaven was on earth," "those were the happy, happy days" dismiss the account as

60 Pamuk probably refers to the series of Anatolian revolts against the Ottoman state that followed the death of Sultan Suleyman I in 1566. Ottoman historians named the revolts after "a certain Sheik Celâl" (Ágoston and Masters 127). Significantly enough, one of the causes of the revolts is believed to be "the influx of cheap silver from the Americas," which destabilized the market and brought a generalized unrest (ibid.). The reference to the celâli revolts may thus offer an indirect critique of the flow of American products into Turkey and its aftermath. 
excessively emotional. Hence, Pamuk's construction does not partake as much as Shafak's in the utopian tradition.

Furthermore, the emotions connected to the two romanticizations of the Ottoman Empire are very different. Indeed, The Black Book was published at the dawn of a dark decade and seems to be a preamble to the Nineties' pessimism. In the words of Ömer Tasspinar, "during the 'lost decade' of the 1990s, the Turkish economy was plagued by recession, an average inflation rate of 70 percent, structural budget deficits, chronic financial crisis and constant political instability" (Taşpinar, "Three Strategic Visions" 4). Moreover, the feeling that Turkey was not receiving the respect it deserved from the West generated a "narrative of frustration vis-à-vis Europe and America" (Taşpinar 5) clearly recognizable in Pamuk's The Black Book and The New Life. Elif Shafak's Ottoman utopia, instead, is rooted in the cultural openness and "unprecedented sense of self-confidence" of Erdoğan's neo-Ottomanism (Taşpinar 4).

In spite of the different socio-political environments in which they are generated, Pamuk's and Shafak's Ottoman utopias do reveal shared traits. Both texts are permeated by "the longing for a lost presence" (Almond 81). Both authors locate their utopia in one specific expression of Ottoman or pre-Republican culture. Shafak chooses the life on the islands as a symbol of the lost culture of cosmopolitanism, whereas Pamuk locates his utopia in a vision of Hurufi villages which, besides Islamic mysticism, also bring to mind a pastoral environment, a most appropriate frame for a Golden Age. Besides, both utopian constructions question Kemalist narratives. The severance of signifier and signified and the estrangement of a people from their language and culture in modern Turkey brings to mind the Kemalist ideology and reforms in general and the 1928 language reform in particular. With the language reform, Kemalism banished words of Persian and Arabic origin as well as terms deriving from religion and folklore in order to 'turkify' the language, and switched from the Arabic alphabet to the Latin one. Similar to Shafak's islands, the linguistic dimension is central in Pamuk's age of Hurufism, since the empire's citizens could once fully identify with their alphabet, language and literature, which mirrored and contained the meaning of their everyday lives. In light of Turkey's adaptation to Western models and aesthetics in The Black Book, the Hurufi passage exposes the gradual but irreparable alteration of Ottoman culture in the process of Westernization.

The two novels and their Ottoman romanticizations share the implication that a fundamental part of Turkish culture has been lost in the passage from empire to republic. In Shafak, the coming of the republic brought about the loss of cosmopolitanism, while, in The Black Book, the republican age caused the loss 
of the unity of signifier and signified. Almond describes the use of Islam in The Black Book as "an all-purpose social glue" (Almond 82), and in Pamuk's golden age, Hurufism is indeed the glue binding together signifier and signified. Hurufi poetry in particular seems to best express this sense of unity and, as a result, also the identification between the Anatolian ethnic groups and their culture:

on warm moonlit summer nights, when travelers dipped buckets into wells, they pulled out not just ice-cold water but pailfuls of mysterious signs and stars, and they would stay up all night, reciting verses that illuminated the meaning of signs and the signs of meaning. (302)

The reported passage makes readers aware of the importance of wells as repositories of the forgotten Ottoman culture, which seem to originate and thrive underground. In this case, a fruitful exchange between the underground and the surface is facilitated by the upward and downward movement of the bucket, making sure that the signs and symbols contained in the depth of the Turkish soil can be brought to the surface. The constant dialogue between the culture on the surface and that "vast, unlimited discourse, continuous, and silent" (Foucault 67) that flows beneath it like water seems to be what makes it possible for Ottoman citizens to effortlessly articulate their cultural identity.

Islamic mysticism is indeed crucial in the construction of an Ottoman utopia as a critique of Kemalism. Erdağ Göknar states that Sufism "allows the reenchantment $[\ldots]$ of a literature disenchanted by the secular masterplot" "Blasphemies" 311). For this reason, Göknar continues, Sufism provides "a useful counternarrative to the dialectical logic of modernization, and Pamuk makes innovative use of this tradition in constructing his novels" (ibid.). Islam in general, but especially Islamic heterodoxies like Sufism and Hurufism, were also among the aspects of Turkish culture targeted by Kemalist revisionism. The Black Book brings together the banishing of Sufi orders with the language and alphabet reform in a single lamentation. The following quotation refers to the burning of Sufi adepts during the reign of Sultan Beyazid II, but a reference to the introduction of the Latin alphabet transfers the event symbolically to the $20^{\text {th }}$ century:

when he studied the sinuous flames licking up against their bodies, he could easily make out the alifs and lams that made up the first four letters of the word Allah; but stranger still - as these men were consumed by the flames of the Arab alphabet, the tears falling from their eyes resembled the O's, U's, and C's [sic] in the Latin alphabet. This was the first time Galip had come across a Hurufi response to the 1928 Alphabet Revolution, when the country moved from the Arabic to the Latin alphabet. (300)

The violence of this scene reminds one of the dramatic terms in which Shafak refers to the Kemalist language reform of 1928 as "linguistic cleansing" (Shafak, 
"Linguistic Cleansing" n.p.) resonating with 'ethnic cleansing' projects of nationalist regimes.

Yet, a dense irony permeates Pamuk's description of the age of Hurufism. It becomes gradually clearer to the reader (before it does to Galip) that in spite of the abundance of signifiers, there is no mystic signified, the novel's treasure hunt does not lead anywhere, and the essentialist notion of culture Galip pursues so devotedly is in fact a delusion. In Foucault's terminology, Galip eventually realizes that not only can he not decipher the "legible face" of its culture, but that his culture never had a "legible face" (Foucault 67). This is not only due to the interventions of Kemalism on a preexisting culture, allegedly so profound to make Turkey's 'real' identity irretrievable, but also to the fact that, according to The Black Book, Turkey had never enjoyed a period of cultural wholeness like the one portrayed in the Golden Age of Hurufism. The irony is also contained in the blatant romanticization of the Ottoman Empire and the credulous ingenuity of the protagonist, so eager to be sucked into an a-historical rendition of Turkey's pre-Republican past. In light of these last observations it is possible to conclude that irony, invalidating Pamuk's Golden Age and completely absent in Shafak's Ottoman utopia, is one of the elements that mostly differentiate the two romanticizations of the Ottoman era.

Up to this point, it can be argued that neo-Ottomanism influenced both utopian constructions. This finds confirmation in Göknar's definition of this political phenomenon and its literary reverberation, identified as a specifically Turkish expression of international postmodernism, which, in a Turkish context, might be alternatively and perhaps more suitably defined as "post-Kemalism, post-socialism, and, most importantly, neo-Ottomanism" ("Ottoman Theme" 35). More precisely, Göknar explains, literary manifestations of neo-Ottomanism reflect aspects of post-national or transnational aesthetics such as the "reassessment and reappropriation of disregarded cultural history and identity [...]. In an authoritarian political context, the limits of nationalism were discursively transcended, historical and cultural borders were crossed" (ibid.). Both romanticizations question the narratives of Kemalism: they both appropriate themes, words, cultural manifestations of the imperial period to point at the failures of modernization, and they embrace the Ottoman and Islamic heritage repudiated by Kemalism.

Yet, as I mentioned, the two romanticizations were generated in two contingent and yet widely different periods of Turkey's history: the early 1990s and the early 2000s. The former are remembered as a decade of economic and social instability pervaded by pessimism and lack of confidence, but one that witnessed a growing interest in the rediscovery of the Ottoman history and Ottomanesque 
language (Göknar, "Ottoman Theme" 35). Correspondingly, the novel portrays the irreparable fragmentation of Turkish identity and the demise of an organic idea of culture, featuring the complete identification of language and meaning, individuals and culture. A decade later, Shafak's texts, written in a period of economic stability and pervaded by neo-Ottomanist confidence, open up to the aesthetics of globalization and post-nationalism and offer a more optimistic representation of the search for Turkey's post-Kemalist identity. In fact, transcending the Kemalist rigid dynamics of inclusion/exclusion of cultural elements in Turkey's identity, Shafak's Ottoman utopia proposes a hybrid notion of Turkishness, considering modern Turkey as the result of all the cultural influences that followed one another. A renewed Ottoman model is therefore, in Shafak's texts, an appropriate societal option for a globalized period where nationalist paradigms are about to be overcome. If on the one hand the Ottoman model implied the inclusion of imperial minorities in a wider idea of Ottoman citizenship, accepting each group's cultural contribution to the making of a wider 'imperial' identity, on the other hand the neo-Ottomanist paradigm opens up to more recent cultural influences as well, "embracing the West as much as the Islamic world” (Taşpinar, “Three Strategic Visions” 2). On this point, Pamuk's and Shafak's utopias differ greatly.

In The Black Book, there is no room for the United States in the (attempted) definition of Turkish identity, quite the opposite: the United States is part of the problem. The novel suggests that American cultural imperialism and the Kemalist obsession with replicating Western models has supplanted Turkey's 'original' culture and aesthetics, and produced an unbridgeable fracture between Turks and their cultural heritage. In the words of Benton Jay Komins, "Pamuk uses globalized culture, in an overly determined American guise, as a critique of the Turkish experience" and equates post-Kemalist Turkey with a "pax Americana" (Komins 15), a term that echoes and mocks the concept of Pax Ottomana. There is therefore no connection between Ottoman past and globalized present on the ground of cosmopolitanism and tolerance, let alone the kind of continuity Shafak hypothesizes. Shafak reserves a completely different treatment for the Unites States and their influence on Turkey's present. American themes and narratives are woven into the texture of her own Ottoman utopia. In this sense, differently from Pamuk's, Shafak's utopia can be considered a transnational narrative, engaging in a parallel dialogue with two national dimensions, the Turkish and the American. 


\section{Two Approaches to Cultural Identity}

Pamuk's and Shafak's dissonant representations of post-Ottoman Turkish identity are reminiscent of the two different ways of thinking about cultural identity theorized by Stuart Hall in his essay "Cultural Identity and Diaspora" (1989), which addresses the retrieval of an 'African' identity in the Caribbean islands. I suggest that Hall's theories can be brought to bear on Shafak's and Pamuk's work, as both writers perceive Turkey's Republican age as an agent which separated the population from its cultural heritage by imposing alien ethics and aesthetics imported from the West. In this sense, debates regarding identity in modern Turkey are, to an extent, comparable with those of postcolonial contexts.

According to Hall, in postcolonial and diasporic contexts identity may be regarded as "a sort of collective 'one true self, hiding inside the many other, more superficial or artificially imposed 'selves' [...]. This 'oneness', underlying all the other, more superficial differences, is the truth, the essence." The task of the diasporic individual is therefore to "discover, excavate, bring to light" this identity (Hall 223). This image of an 'archeological' research implying the removal of superficial strata is very much part of Shafak's and Pamuk's methodology. On the one hand Pamuk constructs an imaginary 'authentic' Istanbul under the city's surface, where the nation's cultural heritages - a series of conquered and forgotten civilizations - had deposited. On the other hand, this excavation is crucial to what one perceives to be Shafak's purpose as a writer, as she appears invested in the rehabilitation of the Ottoman and Islamic legacies. Shafak herself clarifies her partaking in this 'archeological' process of uncovering in her 2005 interview with New Perspectives Quarterly, which also hints at Pamuk's involvement in the same mission:

NPQ: That's something that also concerns Pamuk's work. "Whatever is suppressed," he told me once, "always comes back." In the same way you are the one who always comes back to capture the forgotten past through your novels. Are you in the same boat with Pamuk?

Shafak: Yes, definitely, but I do it in two ways. I do it both with the content of my novels, in other words with the stories I deal with, and also I do it with my style. I do not only try to unearth the stories that have been buried under the ground by the Kemalists. I also try to unearth the words that have been kicked out of Turkish language. I bring them back. (Shafak n.p., emphasis added)

The spaces constructed by the two writers and analyzed in this chapter also connect to Frantz Fanon's advocacy of a "passionate research [...] directed by the secret hope of discovering beyond the misery of today, beyond self-contempt, resignation and abjuration, some very beautiful and splendid era whose existence 
rehabilitates us both in regard to ourselves and in regard to others" (Fanon 170, emphasis added). This idea informs Shafak's Ottoman utopia and, in particular, Pamuk's Golden Age of Hurufism, whose splendor creates a stark contrast with the miserable existence affecting the city on the surface, prey of amnesia and self-contempt.

Pamuk's approach to the search of Turkey's identity appears pessimistic in comparison to Shafak's more optimistic perspective, opening up Turkey's borders to a global sensitivity instead of collapsing under the weight of irreversible Westernization. In fact, the archeological process that hopes to retrieve an intact cultural essence by simply removing unnecessary strata implies the same strategy employed by the designers of Turkish nationalism, namely, the elimination of unwanted cultural heritages. In this case the removal would concern Kemalism and Westernization, in other words "the dark moment in recent history that some call the road to democracy" (Pamuk 307), as opposed to the Golden Age of Hurufism and to the 'authentic' Istanbul resting underground. By retrieving Istanbul's pre-Republican name, Café Constantinopolis in The Bastard enacts a comparable process of historical selection and removal. Shafak, however, presents the café as a flawed model of cosmopolitanism and re-orients it towards more integrative solutions.

Paradoxically, Hall indicates an archeological process intended exclusively as subtraction of alien cultural strata, without the creation of new meaning, as a symptom of "collu[sion] with the West which, precisely appropriates and normalizes [the colony] by freezing it into some timeless zone of primitive, unchanging past" (Hall 231). This view is supported by Said in Orientalism, where he describes the Orientalist scholar's perception of his work as "having uncovered, brought to light, rescued a vast amount of obscure matter" (Orientalism 127, emphasis in the text). The flaw in Galip's search of a holistic Turkish identity and of Hall's first notion of cultural identity - might therefore be located in the unconscious compliance with the West and its "imperializing eye" (Hall 234), but also in the lack of a constructive project that may counterbalance the bitter realization that Turkey cannot retrieve its 'original' identity.

What allows the diasporic writer to transcend this archeological delusion is the capacity of integrating recent historical transformations into the vision of a cumulative, multilayered identity. In other words, one could alternatively consider national identity as a result of all the cultural influences, although traumatic, that followed one another through the course of history - including imperial occupation or, in Turkey's case, Kemalism. In fact, Hall's second approach to cultural identity "recognizes that, as well as the many points of similarity, there are also 
crucial points of deep and significant difference which constitute 'what we really are'; or rather - since history has intervened - 'what we have become"' (Hall 225). In Pamuk's novel, Galip's obsessive search for Turkey's true self is mostly concerned with "what we really are" rather than with "what we have become." According to Hall, integrating historical transformations instead of removing them is a decisive aspect in the production of diasporic identity. For diasporic subjects, Hall adds, cultural identity is determined precisely by "the ruptures and discontinuities" and "the mixes of colours" (ibid.).

These two fundamental elements of diasporic identity - cumulative integration of diverse cultural influences and emphasis on heterogeneity - can be found in Shafak's imaginary spaces. In the first place, Shafak's Ottoman utopia consists of a construction of an Ottoman Golden Age hybridized with elements coming from the American and Western traditions. Moreover, the Ottoman utopia, informed by the notion of productive nostalgia - "a longing oriented towards the future as well as towards the past" (Blunt 719) - can be successfully juxtaposed to Hall's representation of diasporic cultural identity, in this second sense, as something that "belongs to the future as much as to the past" (Hall 225). Secondly, Hall's understanding of national uniqueness as depending precisely on the heterogeneity of its tradition, on its "ruptures and discontinuities," is reminiscent of Elif Shafak's appeal to Turkish citizens to "stay happily situated in this unreasonable synthesis of ours" (Shafak, "Chimera" n.p.).

Even though both perspectives on cultural identity are part of the postcolonial experience, they are not equally significant. If the first perspective "play[s] a critical role in the postcolonial struggle" (Hall 223), the second is much more complete, realistic, and challenging, since "it is only from this second position that we can properly understand the traumatic character of the 'colonial experience"' (225). The first perspective, struggling to retrieve a fictive primordial culture located in an imaginary Golden Age, contains the risk of colluding with the Western gaze on the colony/the Orient. The second perspective, however, comes to terms with the irreversibility of history and of Western influence, and yet resists its "imperializing gaze" (234).

Nevertheless, another element allowing the transition from mourning the loss of meaning to the production of a hybrid, transnational identity for Turkey is the diasporic experience. Even though The Black Book is very much concerned with the perception of the United States and the West in Turkey, it does not address diasporic experiences. Shafak, instead, whose literary production straddles the United States and Istanbul, can more easily share Hall's second view of cultural identity as inclusive and cumulative, rather than exclusive and subtractive. 
Shafak's diasporic experience makes her aware of "a necessary heterogeneity and diversity" and allows her to champion "a conception of 'identity' which lives with and through, not despite, difference" (Hall 235). This becomes manifest in Shafak's imaginary cafés, those spaces of the like-minded that can be redeemed through the penetration of the colonial Other: an Armenian in a Turkish café and a Turk in an Armenian one. 



\section{Rewriting History, Rewriting Religion}

The present chapter addresses rewritings of history and religion in the works of two authors of Turkish American literature: Halide Edip and Elif Shafak. My comparative approach will highlight the remarkable continuities that link the work of Edip and Shafak and show how both reclaim Turkish history and religion from the predominantly patriarchal visions of Kemalism and Islamic orthodoxy, 'rewriting' them into a matrifocal perspective that exalts the voices of feminine subalterns. Besides, by showing a net of correspondences that link Edip's and Shafak's works, I will highlight a continuity of strategies, imagery, and concerns between two of the most representative exponents of Turkish American literature.

The first section of this chapter will present Halide Edip's autobiographical volumes, Memoirs of Halide Edip (1926) and The Turkish Ordeal (1928), as pioneering works of Turkish American literature, as they establish a transatlantic connection between Turkey and America on literary, cultural, and ethical grounds. These two works construct America and Turkey as countries that share a fervid love of independence and conceived comparable revolutionary projects. Edip's writings found resonance in the later work of Shafak, who retrieves situations, facts, and images from Edip's memoirs, empties them of their nationalist significance, and reframes them into a multicultural context.

After providing an introduction to Edip's 'subversive' historiography and to the reasons why her work should be read in a transnational perspective, this chapter's focus will shift to Shafak's reworking of Edip's themes into a neo-Ottomanist framework in the early 2000s. Used by Edip to legitimize Turkish sovereignty over Anatolia and to underline the dramatic necessity of a Turkish struggle for independence, historical loci such as ferries and orphanages assume an almost oppositional value in Shafak, who turns them into spaces that celebrate multiethnicity.

If Edip's and Shafak's rewritings of history aim to substitute patriarchal ideology with what are claimed to be collective experiences of women, their rewriting of religion goes into the same direction, focusing on the renegotiation of womanhood within the patriarchal logic of Islam. Edip's and Shafak's rewritings do not merely share a focus on the transition of women from silent, marginal objects to subjects endowed with voice and the power of description; I also want to suggest that, in the texts that constitute the focus of this chapter, the discussion of gender generally runs parallel to the attempt to reconcile Islam and Christianity 
by emphasizing affinities and downplaying differences. In both cases, the systematic search for parallels between Islam and Christianity is carried out in a markedly American perspective. Edip's and Shafak's commitment to bridge the gap between what Edip problematically calls "the Moslem mind and the Western mind" (Ordeal 119) goes beyond the necessity to mediate between the East and the West, but can be read in an explicitly binational, transatlantic perspective connecting Turkey and the United States. Earlier studies have suggested that Edip's vision of a universalist Islam, the values and figures of which are compatible with those of Christianity, is the result of her early education at an American college for girls. Shafak tries, through her writing, to mitigate the global climate of tension that followed the terrorist attacks on September 11, 2001. Her celebration of Sufi Islam as a possible way of alleviating the "troubled framework" (Shafak, "The Religion of Love" n.p.) of post 9/11 society will provide a starting point for my research in this chapter and the following.

\section{Between Imperialism and "Wholesome Curiosity": Halide Edip's Benevolent America.}

\footnotetext{
"They laughed and told me that Avropa (Europe) had sent them to do it all, and that they would never leave us in peace. That man Avropa must be told, daughter: he must leave us, the poor peasants, alone. What have we done to him?" Halide Edip, The Turkish Ordeal.
}

Halide Edip Adıvar ${ }^{61}$ (1884-1964) was a prominent Turkish novelist, journalist, social activist, feminist, and a "figure of controversy" in modern Turkey (Göknar, Orhan Pamuk, Secularism and Blasphemy 150). During the early stages of the Turkish War of Independence (1919-1923), Edip used to be a very close collaborator of Mustafa Kemal Atatürk, and an active member of the nationalist movement. The relationship between the future prime minister and the writer gradually deteriorated when Kemal's ambition to emerge as a charismatic leader and 'Father of the Turks' started to collide with Edip's inclination to consider the establishment of the Republic a collective achievement, made possible by a plethora of more or less influential figures maneuvering the conflict from behind the scenes. After the war, Edip and her second husband, a highly esteemed Istanbulite doctor, were accused of treason by the one-party Kemalist government and forced into exile, first to London, later to Paris. In 1926, Edip left Turkey not to return until Ismet Inönü’s pardon in 1939. In exile, Edip intensified her

61 Halide Edib is another common spelling of the author's name. 
intellectual activity and penned a two-volume autobiography in English that would be remembered as one of the most controversial works of Turkish literature. The two volumes, Memoirs of Halide Edip (1926) and The Turkish Ordeal (1928), present an account of Turkish history perceived and narrated through the eyes of a woman: from the last years of the empire down to the Young Turks' revolution (1908), the War of Independence, and the birth of the Turkish Republic (1923). The autobiography, written and published in English, challenges the narratives of Kemalist historiography, substituting the myth of Kemal as infallible patriot and national hero with more nuanced narratives that exalt the people of Turkey, especially women, as the real protagonists of the conflict. Hülya Adak has suggested that Edip's autobiography, in particular The Turkish Ordeal, should be regarded as a historical counternarrative that questions the identification of Mustafa Kemal with the nation of Turkey and dismantles the quasi-religious cult of Kemal as a transcendent, unchallengeable, prophet-like leader (see Adak, "National Myths and Self-Narrations"). By interweaving her own biography with a collection of stories of women, Edip reconstructs Turkish history from a feminine-plural rather than a masculine-singular perspective.

Edip's autobiography can be read as a highly significant historical work marking a moment of rupture and one of continuity. Firstly, it marks what Clifford describes as "a fissure in which time stops and restarts," allowing the recovery of effaced stories, and the imagining of different futures (Clifford 318). While the newly born Turkish Republic embraced Atatürk's historiography and policies of detachment from Ottoman and Islamic traditions, Edip articulated her discordant historical narrative in an international, Anglophone sphere. Therefore, the 1920s represent a node in Turkish historiography, or a "fissure," witnessing the emergence of a second version of history, challenging the official one, and developing independently. Secondly, Edip's version of history strongly differs from the Kemalist one as it establishes a fundamental continuity with Turkey's Ottoman tradition of multiculturalism. Yet, Edip's text never broke through the monopoly of Kemalist historiography and dwelt, as Adak puts it, in a state of "potential resistance" (Adak 524). Written in English and published in London, the book was intentionally situated outside the boundaries of the Turkish national literary market, and primarily addressed Western readerships. This implies that Edip's is a pioneering work as it projects Turkish literature from a national level to a global one, but also that her autobiographical volumes are - much like the author herself - self-exilic subjects, as Edip deemed them not to be suitable for Turkish audiences and extracted them from the national literary scene. 
Edip discusses her choice of writing and publishing her memoirs in English towards the middle of The Turkish Ordeal, in a passage that describes a heated argument with Atatürk:

I knew very well that he would never forget the incident of that evening, but that he would appear as if he had, and that I would be expected to go on working as though nothing had happened. But just then I couldn't: I would try to tell the story of Turkey as simply and honestly as a child, that the world might some day read it - not as a historical record nor as a political treatise, but as a human document about men and women alive during my own lifetime; and I would write it in a language far better fitted to reach the world than my own. It was that very night, as I lay in bed after the scene with Mustafa Kemal Pasha, that I determined to write my Memoirs and to write them in English. (Ordeal 132)

The passage represents perhaps the most effective, although belated, 'introduction' to the book's origins and purposes. Two crucial elements emerge. First, the idea of writing an autobiography appears to be the product of an argument with Atatürk, which he ends rather abruptly: "I don't want any consideration, criticism, or advice. I will have only my own way. All shall do as I command. [...] You shall obey me and do as I wish" (Ordeal 130). After this divergence, Edip consolidates her refusal to submit to Atatürk's abuses by dissociating from his vision of history, and choosing to develop her own. Secondly, the text poses a question of implied readership. The choice of English, "a language far better fitted to reach the world than my own" (132), implies that the text is directed to an international rather than national readership. Edip was probably aware of the fact that her book would be ostracized by the Kemalists once they had settled into power, and addressed it to more receptive readerships. To the present day, Edip's autobiography hardly found its way back to the home country and is still dwelling in an Anglophone sphere: the first translation of The Turkish Ordeal into Turkish appeared in the 1960s with the title The Turkish Ordeal with Fire. The translation contained massive modifications to the text in English and betrayed the message of the original by paradoxically endorsing the myth of Kemal as the nation's prophetic leader (Adak, 524).

Multiple attempts to interpret Anatolian culture to the West and adopt a Western perspective confirm that Edip's memoirs are primarily (although not exclusively) oriented toward a non-Turkish readership. "It is impossible for a Westerner," she explains, speaking of Smyrna/Izmir between Greek and Turkish occupation, "to imagine the desolation of the city and the horror of the stories one heard" (Ordeal 306). Since the book was written in London and Paris, but printed and published in England, one could expect Edip to address a primarily European or British readership, but the extremely positive portrait of America emerging from 
the text, combined with relentless criticism of European powers, suggests that the autobiography's implied readership is an American one.

In order to demonstrate that Edip's memoirs are not merely a text to be read in a European context, but in a transatlantic one, I will focus on The Turkish Ordeal, depicting the struggle of the Turkish people against the Allied powers, which aimed to dismember and portion out the territories of the empire. In this scenario, the United States appears to be the sole recipient of the narrator's esteem and appreciation, being the only Western country capable of engaging in a sincere dialogue with Turkey in the midst of what Edip calls a conflict between two ideals "which in those days were known as the Garb-Mefkuressi (the Western ideal) and the Shark-Mefkuressi (the Eastern ideal)" (Ordeal 119). The next section will present three areas that illustrate Edip's portrayal of a 'benevolent' ${ }^{\prime} 2$ America and provide evidence of how The Turkish Ordeal hopes to establish an exclusive transatlantic connection and cultural kinship between Turkey and the United States. The contrast between America's supposedly benign presence and the imperialist designs of European states in Edip's text is so conspicuous that it will eventually result in a reconfiguration of the notion of 'West.'

Edip's autobiographical works and their persistent investment in bringing to the surface cultural affinities between Turkey and the U.S. can be contextualized as part of a general interest in the improvement of Turkish-American relations which was widespread the 1930s. On the occasion of the two-hundredth anniversary of George Washington's birth, American Ambassador in Turkey Joseph Grew (1927-1932) declared it was "impossible [...] not to see the analogy between the American Revolution of 1775 and the Turkish Revolution of 1920, not to see the similarity between George Washington and Mustafa Kemal" (Yilmaz 227). Still, Edip's work is unique for a variety of reasons. First of all, as Şunhaz Yilmaz points out in "Challenging the Stereotypes: Turkish-American Relations in the Interwar Era," interventions that strengthened and celebrated the Turkish-American

62 The term "benevolent," with reference to American overt or covert expansionism, also appears in Heide and Poiger's Transactions, Transgressions, Transformations: "in the decades since WWII, U.S. producers and commentators have frequently imagined American culture [...] as explicitly anti-colonial. At the same time, they, like U.S. politicians, have affirmed a 'benevolent supremacy' of the United States over both the formerly (formally) colonized and the former colonizers" (Heide and Poiger xxiv, emphasis added). In Modernism and the Middle East, Sibel Bozdoğan compares the Istanbul Hilton to "'a little America, the paradigm of benevolent and democratic capitalist society that the DP [Democratic Party] regime embraced as its model” (Bozdoğan 120, emphasis added). 
friendship were mostly the work of Americans. "Turkish propaganda activities to improve their image in the United States," Yilmaz reports, "had been almost nonexistent" (229) in comparison with the extensive efforts made by American politicians, diplomats, and intellectuals.

Therefore, the fact that a (female) Turkish public figure such as Edip produced this kind of texts, participating in a prominently American discourse that aimed to rehabilitate Turkey's image abroad, is per se exceptional. Secondly, the tone of American speeches and publications was celebratory, as they mostly praised the reformative spirit of the Turkish republic, applauded Atatürk as a 'Western' leader, and repudiated the stereotype of the 'terrible Turk.' Edip's work goes into a different direction, as she attempts to boost Turkey's reputation in the eyes of American readerships not by reminding them of the extraordinary nature of Turkey's achievements, but by underlining how culturally affine the two nations are, and especially by indicating that the Turkish nationalist struggle is not unlike the American. Yet, Edip did not shy away from exposing the pitfalls of Kemalist nationalism and separated the value of the Turkish nationalist cause from its all too charismatic leader. Yilmaz credits Edip for "significantly contribut[ing] to publicizing the improvements in Turkey through her publications and speeches in the United States" (230): my analysis takes Yilmaz's judgment further, to demonstrate that there is more to Edip's contribution to diplomatic relationships between Turkey and the Unites States. To Edip, Turkey and the United States were more than diplomatic allies: they shared political ideals, moral principles, and cultural practices.

\section{Imperialism and Humanitarianism}

In the 1910s and 1920s, Entente powers including Britain, France, and Italy hoped to profit from the partition of the Ottoman Empire and gain the most from its dismemberment. In spite of the fact that America, associated with the Entente but not truly part of it, showed little interest in taking a mandate over the newly born Republic of Armenia and was not among the signatories of the Treaty of Sèvres, it would be inaccurate to claim that the American presence in Anatolia was exclusively motivated by humanitarian reasons. In fact, in 1919, the American Chamber of Commerce for the Levant stated that "the opportunities for American expansion in the Middle East [were] unlimited [...], with the conclusion of peace, there [was] the structure of an empire to be developed" (Housepian 57). Nevertheless, Edip's autobiography adamantly condemns European imperialist designs on the former Ottoman territory and depicts a selfless 
America, acting as a super partes observer in the conflict between the Muslim Turks and the alliance of European powers and Ottoman Christian minorities.

In describing the European and British presence in Anatolia, Edip resorts to imperial terminology, condemning their desires of territorial gain and exposing a mischievous alignment of the Allied powers and the Ottoman Christian minorities. To Edip, Europeans in Anatolia are occupiers, persecutors, and invaders (Ordeal 61, 106) whose ultimate goal is "converting Turkey into a series of colonies" (112). David Lloyd George's England appears "determined to exterminate Turkish rule in Asia Minor and replace it by a vast Greek empire" (162). Edip enthusiastically vouched for the American protectorate as the most reasonable option for Turkey's future, regardless of the fact that this idea clashed with the nationalists' repulsion for external limitations on Turkey's sovereignty (314). In fact, the hypothesis did not meet Atatürk's favor, and eventually drove the leader to brand Edip as a traitor of the Turkish cause.

Under the shadow of an ugly partition the enlightened Turks naturally turned their eyes to President Wilson and America, which showed no desire for territorial acquisition in Turkey. [...] America was to help Turkey financially and economically, send experts and advisers for a certain number of years, guarantee a period of peace in Turkey, and give the Turkish nation a chance to start a new regime and set up internal reform. (Ordeal 12)

Edip stresses that America, differently from the European powers, had no interest in political expansion on the former imperial territories, and that its presence was motivated by purely humanitarian reasons. This is understandable in so far as during the War of Independence American interests in Anatolia were not yet declared or perceived as imperialistic (Başci 119). Throughout the War of Independence American missionaries "conveniently dissociated themselves from European imperial powers," allowing the U.S. to maintain a "privileged position" in the Turkish public opinion, as opposed to Europe (ibid.). Later texts covering the same age are much less naïve in assessing the American presence in Turkey. Marjorie Housepians's The Smyrna Affair (1966), for instance, while at times extremely appreciative of American humanitarian missions in Turkey, describes American intervention as Janus-faced: "one face is miss liberty, the other eagle-eyed and imperialist looking for opportunities of expansion" (Housepian 56).

To Edip, the American protectorate appears as the solution "enlightened" Turks most naturally wished for, in contrast to "the shadow of an ugly partition" which would have handed over the fragments of the Ottoman Empire to the Allies. Through a dramatic contrast of darkness and light, Edip portrays America 
as a salvific agent capable of rescuing Turkey from the darkness of European expansionism. Seçkin Ergin and Ahmet Beşe indicate that Edip’s light-and darksymbolism might be "reminiscent of her Anglo-American education" (Ergin and Beşe 160): in fact, this duality features prominently in the missionary imagery. Pelin Başci underscores that missionary rhetoric "emphasized the opposition between the light diffused by the progress of Christian civilization and the darkness of other traditions and cultures" and that "the missionary enterprise was perceived as a "universal struggle between the children of light and the children of darkness"' (Başci 107).

\section{True Christians and very Unchristian Christians: American Humanitarianism in the Empire Territories}

What links Edip's work, Christian missionary rhetoric, and the United States is Edip's direct experience with missionary education at the Üsküdar American Academy for Girls. At the end of the $19^{\text {th }}$ century, as the Ottoman Empire became increasingly Westernized due to a series of structural reforms, "schools run by the missionaries opened one after another," enabling upper-class Ottoman girls to access a 'Western' or 'American' education (Ergin and Beşe 98). Edip graduated from that college in 1910, and spoke fondly of it. In a eulogy written for the Turkish press, Edip admits to having "love[d], love[d], love[d] everything about the college" (Edip in Sönmez 83). Başçi regards Edip as a product of Western education and indicates that the writer was "embraced by the missionaries as one of their own" (119). Ergin and Beşe describe Edip as a product of her time, a representative of "a group of Turkish intellectual women with a good command of English, and familiarity with the Anglo-American culture" who became involved in politics and attempted a transfer of American values and ideals on Turkish soil (103). Thanks to their experience at American missionary schools, this group of women developed an intellectual and emotional bond with the United States. This bond is of central importance the work of Edip, who felt "culturally affiliated" to the U.S. (ibid.).

Historian Anat Lapidot-Firilla defines the years between 1880 and 1920, including the Turkish War of Independence, as "The Golden Age of missionary enterprise in the Middle East," but the work of American missionaries in Anatolia began as early as 1820 (Lapidot-Firilla 154). Among missionary associations and organizations, the Near East Relief (NER) was the most prominent. The influence of this organization, Lapidot-Firilla explains, was "immense": its affiliates ran colleges, schools, rescue homes for women, refugee camps, hospitals, bazaars, and 
orphanages (156); the orphanage in The Turkish Ordeal that appears later in this chapter is also a NER facility.

The role American missionary and relief organizations played in the establishment of American political interests in Anatolia is the object of controversy, and therefore very hard to assess (see also Başci 101). To put it with political scientist Jeremy Salt, the place of relief institutions in imperial and colonial history is "idiosyncratic," as these "unreliable allies" of Western governments did disseminate Western values, but did not feel attached to any temporal power, as they believed to be doing God's work exclusively (Salt 310). Lapidot-Firilla assesses NER influence in terms of "informal diplomacy [...] of compassion" (167) emphasizing that, although the priority of NER activists was at all times the well-being of the local populations, they indeed "contributed in further establishing American informal diplomacy and American consumerism" (156) and "served American interests in the Middle East" (159). Başçi dispels ambivalences by labeling missionary facilities as "instruments to transform minds and to reconstruct [a] society" in which "the "Anglosaxon mind would steadily gain influence over the course of events" (Başçi 103-104). On a similar note, Ann Stoler argues that euphemistic denominations for forceful occupation and humanitarian ventures i.e. "imperial guardianship, trusteeships, delayed autonomy, temporary intervention, conditional tutelage, military takeover in the name of humanitarian works, violent intervention in the name of human rights, and security measures in the name of peace" - do not redeem imperial projects: to the contrary, they are constitutive of them (Stoler 8).

This is particularly relevant because in her autobiographical work Edip insists that the American presence in the Middle East was driven by exclusively humanitarian motives: figures of American missionaries and activists populate Edip's text and her narrator never questions their interest in bringing relief to the destitute populations of Anatolia. By contrast, Edip's account hypothesizes a link between European political expansionism, aiming to "exterminate Turkish rule in Asia Minor" (Ordeal 162), and mass-conversions carried out by former imperial minorities, aiming to weaken the predominance of Islam by Christianizing masses of Muslim children. This parallel corroborates the portrayal of imperial minorities as the agents of European imperialism and exemplifies the narrator's conviction that Turkish identity was being attacked from several fronts and by different means. To Edip, not only was Turkey threatened by external enemies trying to secure a piece of the empire's territories, but also eroded from within. In the following passage Edip narrates how Armenians, put in charge of orphanages, converted masses of Turkish children: 
There were a large number of Turkish orphanages in Anatolia filled with Turkish children whose parents had been the victims of the Armenians. [...] Some Turkish families had taken Armenian children out of kindness and pity without any desire to make them Moslems: for the Moslem Turks do not have the missionary instincts of the Christians of the West. [...] Somehow the Turkish orphans got the worst of it. [...] [They] were being Armenianized daily. The children who were brought to the association were left in the care of the Armenian women, and these Armenian women, either by persuasion or threats or hypnotism, forced the Turkish children to learn by heart the name of an Armenian woman for their mother and the name of an Armenian man for their father. [...] When the children were brought in large numbers from the orphanages of Anatolia they were sent to the Armenian church in Koum Kapou, a hotpot which boiled the Turkish children and dished them out as Armenians. Some children tried to run away but were always brought back. (Ordeal 12-13)

Horrific rhetorical devices like the "hotpot" metaphor suggest a parallel between conversions and cannibalistic practices, and the accounts of psychological violence on Muslim children, hypnotized and abused in the hands of their Armenian tutors, foreground a distinction on ethical grounds between the fraudulent Christians, including Europeans and former Ottoman minorities, and the morally superior Turkish Muslims, who, in the case at hand, "do not have the missionary instincts of the Christians of the West" and therefore act out of "kindness and pity" (12-13).

American missionaries in Turkey emerge as "rare genuinely Christian people among very unchristian Christians," endowed with "admirable ability, tact, and broad-mindedness," and, most importantly, with a "strong sense of justice [that] made [them] very sympathetic to the Turkish cause" (139). Edip adds that, if on the one hand the care and concerns of American missionaries were naturally directed towards the Anatolian Christians, on the other their exceptional humanity made them "very sore at heart" over other Christians' misdeeds and prone to embrace the Turkish standpoint instead (139). When Miss Allan, an American missionary, is invited to visit the Anatolian mainland, devastated and plagued by "Greek atrocities" (231), the narrator of Ordeal admits to feeling "very sorry for her, for [she] knew how she hated to see misdeeds done by Christians" (ibid.). Americans, Armenians and Greeks may share the same religion, but the narrator is certain that, in the face of the crimes perpetrated by the minorities in the name of Christianity, Americans will be inclined to reconsider their original sympathies for overseas Christians and judge according to a universal sense of morality. In spite of their different creeds, Edip believes that a kinship on a moral and ethical basis, stronger than religious affiliation, unites Turks and Americans: a "fundamental oneness of all those who, regardless of race and creed, dare to believe in truth and reality" (9). Edip describes figures of American women 
missionaries in very positive terms and acknowledges that they "were the only foreigners who stayed with the Turkish people from the beginning to the end of their historic struggle, and they were regarded with sincere respect and affection by Turks of all classes" (139). Here Edip elaborates on the supposed closeness between American and Turkish sensitivities, possibly triggered by the conviction that the two countries might share similar aspirations to independence.

Edip's differentiation between true and deviant Christianity resonates with missionary rhetoric, which viewed Protestantism as the 'true' Christianity and dismissed the other Christian creeds as aberrations. The goal of American missionaries in Anatolia was in fact "to carry Gospel truth to the nominal Christians of the Eastern churches" and eradicate "untruth": which included Islam and "the churches of the Eastern rites" as well (Salt 288, emphasis added). In addition, American missionaries viewed Ottoman Christians as "subservient" to their Muslim rulers (Başçi 114). In Ordeal, Edip appropriates this label and depicts them as obedient auxiliaries of European imperialism instead: Edip sees Ottoman Christians as an instrument for the Allies to inflict pain and humiliation on the Turks. She laments the "sense of injustice which the Allies were inflicting by means of these native Christians" (318) and denounces Greeks and Armenians as "agents" of the West: "the West was universally hated in Turkey on account of the massacres and oppression she had suffered at the hands of its agents, the Greeks and the Armenians" (119). Considering Edip's account on the terrible reputation of the West in Turkey, the "sincere respect and affection" "Turks of all classes" feel for American missionaries (139) becomes even more striking.

Edip's exclusion of American missionaries from the imperialistic axis connecting European powers and former Ottoman minorities is in need of further questioning. As Edip herself observes, many of these orphanages that were theatres of mass-conversions were run by the American Near East Relief, wherefore a complete American estrangement from such practices was not credible. In fact, American missionaries in Anatolia undoubtedly had a certain amount of political influence, as they stayed in contact with American politicians, keeping them informed on local developments. At times missionaries pressured their government into military intervention, often with the goal of protecting the rights of Ottoman Christians. ${ }^{63}$ "Missionary involvement," Salt reports, “was instrumental in highlighting the need for foreign governments to protect Ottoman Christians,

63 This, for example, happened on the occasion of the Armenian Massacres of 1894-1896, when outraged American missionaries demanded military intervention from the U.S. government (Salt 307). 
and therefore strengthened the case being argued [...] for European intervention on humanitarian grounds" (Salt 307). Contrary to Edip's expectations regarding a moral affinity between American Christians and Muslim Turks, which would theoretically lead any 'true Christian' to sympathize with the Turkish cause, American missionaries mostly intervened in favor of the Christian minorities of the empire.

\section{An Imaginary Us and an Imaginary Them}

The polarity between Turks and Americans and the morally ambiguous Anatolian and European Christians is mirrored in more concrete political alignments featuring European powers and their agents - Armenians and Greeks - on one side, Turks and Americans on the other. The Turkish Ordeal claims that the former imperial minorities fully identified with the agenda of the European powers. The former section illustrated how Armenians allegedly enforced Western policies and contributed to the weakening of Turkish hegemony by mass conversions. In the following passage, reporting the account of a peasant woman on the ransacking of a Turkish village at the hands of Greek soldiers, the narrator shows how the Greeks brought devastation on Europe's account:

"[The Greeks] laughed and told me that Avropa (Europe) had sent them to do it all, and that they would never leave us in peace. That man Avropa must be told, daughter: he must leave us, the poor peasants, alone. What have we done to him?” [...] The Greeks have made the Sakaria people in general understand that Europe was the responsible power behind-even the stupidest knew it. (233-234)

The narrator's last comment, captioning the woman's story, emphasizes how the Greeks were merely executing Europe's orders or acted on their own initiative enjoying Europe's tacit approval. Not only, in Edip's discourse, do Greeks and Armenians endorse European policies, they also hold significant power over the European states: the "armies of occupation," the narrator states, "saw the Turks with the eyes of the Greeks and the Armenians" (Edip 4).

Edip's delineation of an imaginary 'us' and an imaginary 'them' results in a curious reconfiguration of East and West, and, by the same token, also of the conflict between the Garb-Mefkuressi and the Shark-Mefkuressi, the Eastern and the Western ideal (Edip 119). Edip's West, an inimical entity blinded by the dream of territorial gain and deaf to the people's suffering, includes Europe as well as Anatolian Christians: "The West was universally hated in Turkey on account of the massacres and oppression she had suffered at the hands of its agents, the Greeks and Armenians" (Edip 119). 
Conversely, America does not fall within such definition, not does it ever figure among the oppressors, a category that includes Western as well as Eastern elements:

There was the sultan's government preying on the people; there were the French occupying Cilicia and sending Armenian legions to persecute the people too; there were the Greeks around Smyrna massacring, burning, ravaging, and violating every human law; there were the Allies in Istamboul oppressing the Turks at their pleasure - there was the whole Western world with its everlasting "Down with the Turks!" There were Western statesmen insisting that the big stick should always be used with Orientals, with the unspeakable Turks. (Edip 119)

The narrator enumerates the powers threatening Turkish independence. Remarkably, she refers to the "Sultan's government" as one of them, implying that not only was Turkey being sieged by external potential colonizers, but also kept hostage by internal ones, namely, the Ottoman Christians and the Sultan, whom Edip exposes as another agent of European imperialism: "as not only the sultan but the entire Turkish government seemed entirely in the hands of the English and the Allies" (86). Edip's account covers a period of history when, to put it with Landry, "postcolonial resistance was enacted against the imperialist, and sometimes colonialist, ambitions and armies of external Great Powers but also against internal imperial Ottoman institutions" (Landry 154). While the Europeans embrace the point of view of the Christian minorities and integrate their colonial resentment into their expansionistic policies, only America refrains from adopting the perspective of Armenians and Greeks, supporting the Turkish cause.

In view of the extreme difficulty of getting the Turkish side of the question published inside and outside the country, Turkey owes a great debt to the individual fairmindedness and the wholesome curiosity of the American correspondents at this period. They came to us of their own accord, and it is through their efforts that the Turkish standpoint gradually leaked out through the dense cloud of prejudice and hatred, and the political obstruction of the West. (Ordeal 15)

Relying on qualities such as "wholesome curiosity" and "fairmindedness," American correspondents, like American missionaries, appear as independent and super partes observers, subscribing to the truth and validity of the Turkish struggle for independence. The perceived moral kinship of Turkey and the United States is thus accompanied by an affinity on political grounds, a brotherhood of nations which underwent a struggle for independence. In fact, the narrator repeatedly states that Mustafa Kemal Atatürk was to become Turkey's George Washington (Ordeal 99). 
Edip played a prominent role in the struggle for Turkish independence and in the shaping of Turkish nationalism, yet her autobiography presents a subversive idea of nationalism, far removed from the racial policies and historiographical practices of Kemalism, and much less interested in endorsing the personality cult that developed around the figure of the Turkish leader. Most importantly, as Hülya Adak observes, Edip's autobiography is located in the Western autobiographical tradition, which concerns itself with the development of a changing self, moving from naivety to maturation (Adak 519). Edip's idea of nationalism follows the same trajectory. If in The Turkish Ordeal the narrator does not hesitate to express her belief in the superiority of the Turkish race, labels the Ottoman minorities as traitors and condemns their lack of morality, she ultimately acknowledges every ethnic group in the former Ottoman Empire its share of suffering, and allows shared pain to eventually level ethnic and religious differences.

Towards the end of the book, the narrator acknowledges that governments, not the people, are uniquely responsible for the horrors of war:

The war seemed inevitable on our side. The enemy was in our very homes, and, fighting or no fighting, those homes turned into ashes and our people put to the sword. Why? Simply because a politician or a few politicians had a capricious desire to change the map of Asia Minor. And the Greeks too were caught by the promise of gain and glory without effort. But already they were seeing what it was costing them [...]. Poor Turks ... poor Greeks ... poor world! ... (195)

As The Turkish Ordeal nears its end, the narrator comes to the realization that even the Christian minorities were nothing but pawns on a chessboard on which every move had been orchestrated by European governments.

While Kemal sets out to eradicate Turkey's imperial past from the annals of history and assert the hegemony of Turks in Anatolia, Edip ultimately reconfirms the validity of the Ottoman ideal of solidarity and unity among the diverse ethnic groups that composed the multicultural texture of the empire. Kemal's nationalism - with its emphasis on the creation of a monoethnic, monocultural society - was in line with Western nationalisms. Edip's nationalism, instead, was a multiethnic one. Because of this and other discrepancies between Edip's thought and the Kemalists', the destiny of this subversive counternarrative was one of exile. Disconnected from its home country, the autobiography was published abroad and addressed to a Western implied readership - an American one in particular. 
The American education Edip received may have led her to reserve for America a privileged position in her narration of history. Edip was the product of a missionary school, which greatly impacted her perception of politics and religion. Edip's work, Başci writes, "reflects the influence of the missionaries" and her understanding of religion can be summarized as a "fusion of the spiritual teachings of Islam and Christianity" (112). It is important, however, to mention one more reason that might have influenced Edip's benevolent, hopeful representation of America in her autobiography. Before leaving Istanbul to join the nationalist army in Ankara, Edip entrusts her two children to Charles Crane, an American diplomat, with the request of taking them to America and provide for their education (Ordeal 58). When describing the scope of her autobiography in The Turkish Ordeal, Edip writes:

I thought of [my autobiography] as an attempt to touch people whom I had never met, and would never meet - an attempt to reach distant firesides where human hearts are yearning for true contacts with other human beings who are too far away from them to meet in flesh. But in reality it was to be written above all for the little folk who were just setting out to cross the Atlantic. (133)

Edip admits that her book had been written "above all" for her children. In a way, this detail confirms that, if not at an American readership, the autobiography was at least primarily directed at one located in America.

Although Edip never became a Turkish American subject herself, her autobiography is a pioneering text of Turkish American literature. Since its publication, the book has situated itself on an international literary market, more specifically an Anglophone one. Thus disconnected from the Turkish literary scene, the autobiography develops a transnational trajectory connecting America and Turkey on different levels, and constructs a cultural, moral, and even religious kinship between the two countries. In the preface to her non-fictional book Turkey Faces West (1930), Edward Meade Earl, Professor of History at Columbia University, described Edip as "a voice to which Americans can listen to with sympathy and confidence [...] not new to American readers" (Meade Earl in Edip 19, 21). Most importantly, Edip's writing reverberated in the work of younger authors who deepened the transatlantic connection between Turkey and the United States. Shafak, for instance, has re-elaborated some of Edip's salient images and symbols - such as orphanages and Istanbul ferries - weaving them into a postnational narrative. 


\title{
Ferries and Orphanages: Rewriting the Legacy of Edip's Memoirs
}

\author{
Two powerful woman storytellers meet [...], \\ both working at strengthening the ties among women while \\ commemorating and transmitting the powers of our foremothers. \\ Trinh Min Ha, Woman, Native, Other
}

My study will proceed by exploring how Edip's autobiography resonated in the more recent writings of Elif Shafak. By comparing two passages from The Turkish Ordeal with texts by Shafak, I will show that Shafak retrieves and rewrites iconic urban symbols (the Istanbul ferries) and grey zones of Turkish history (the orphanages during the War of Independence) that appear in Edip's autobiography. I argue that both writers present ferries and orphanages as key spaces reflecting dynamics of conflict and coexistence among Ottoman ethnic groups. If Edip's ferries and orphanages indicate that unbridgeable differences exist between the Ottoman elite and the subject populations and thus reinforce nationalist discourses, Shafak, conversely, presents them as spaces of multiculturalism and reconciliation, suggesting that what unites Ottoman ethnic groups is stronger than what divides them. The representation of Otherness emerging from the episodes at hand reveals how both texts renegotiate dynamics of inclusion and exclusion, reconfigure the borders of East and West, and "write back" to Western or local hegemonic narratives.

In spite of this fundamental divergence, Shafak's writing is indebted to Edip's legacy, as she shares some of Edip's prominent concerns. For instance, the centrality of women and children in the making of subversive historiographical narratives is crucial to both writers. Edip's text shows how the nationalist bias against Ottoman Christians was latent in the everyday life of Turkish women, yet, as the narrator gradually renounces her nationalist standpoint to embrace an all-encompassing idea of Ottoman citizenship, women and children will be the catalysts of her change of perspective. For Edip, women, the sole inhabitants of cities and villages in times of war, are the ultimate guardians of every nation. Correspondingly, works by Shafak such as her first novel in English, The Saint of Incipient Insanities (2005), her best-selling book The Bastard of Istanbul (2007), and the newspaper article "Life in the Islands" present a predominantly feminine universe. In other words, both writers work toward the creation of a matrifocal historiography.

Another element that unites Edip's and Shafak's reconstructions of Turkish history is the choice of English as their literary language, a decision that raises a 
host of questions regarding reception, implied readership, and ambivalent ways of relating to the country of origin. Edip's and Shafak's historical narratives are in fact characterized by a constitutive ambivalence: considering their present-day reception in Turkey and abroad, they are both mainstream and subversive. Even if Edip is now acclaimed as one of the founders of the modern Turkish nation and a pioneer of Turkish feminism, her autobiography, conceived for an Anglophone market, was severely ostracized and did not find its way back to Turkey until the 1960s, the year of publication of the first controversial translation in Turkish. Shafak is a best-selling author, gathering ardent fans among observant AKP supporters as well as among the secular offspring of past Kemalist regimes (see Adil n.p.). Yet, she was repeatedly attacked by ultra-nationalist fringes of Turkish society and tried for having 'insulted Turkishness' according to article 301 of the Turkish penal code, which prohibits Turkish artists and public figures from disrespecting the state and its institutions. Both Edip and Shafak are therefore prominent writers, grounded in the history and society of their home country, but also part of the international literary arena, and very much involved in ongoing debates on cosmopolitanism.

\section{Hullabaloo on the Bosphorus Ferry: The Development of Othering Strategies from "Borrowed Colonialism" to Nationalism}

The ferry anecdote, taking place sometime after the end of World War I and the signing of the 1918 armistice with the Allied powers, is part of a larger section of The Turkish Ordeal which documents the situation in Anatolia after the arrival of the Allied forces: "with the entry of the Allied armies," Edip notes, "the insolence of the Greeks and the Armenians and the treatment of the peaceful Turkish citizens in the streets became scandalous" (5). The passage effectively expresses the narrator's outrage at seeing the city of Istanbul, stronghold of the Ottomans, taken over by former imperial subjects and foreign powers. However, the ferry scene, worth quoting in extenso, is particularly poignant as it focuses on the articulation of difference between the Ottoman ruling elite and the imperial subjects after the empire had collapsed, and shows the overlapping of imperialist and nationalist discourses in Edip's autobiography:

In those days one cause of the disorder in the boats was the fact that the Christian women who had second-class tickets came and sat in the first-class cabin. The attendants and the controllers are mostly Turkish; the company is an old Turkish company. The violent-looking rabble (mostly servant class) who swarmed the first-class cabin always threatened the controllers with the Allied police if they insisted on demanding and getting the difference between the first and second class [...]. On this particular occasion, as 
usual, most of the Christian women in the first class had second-class tickets, and I noticed particularly a Greek woman in brilliant yellow who had pushed two women over on each other's laps to be able to get a seat. When the controller came she announced proudly that her ticket was second-class but that she always traveled first-class when she had a second-class ticket. The controller did not look as mild as she expected.

"All the Turkish women who take a second-class ticket sit in the second class," he said. "They are Turkish," she answered, "I am Greek, and I am protected by the English and the French. I won't sit outside and catch cold. [...] You dirty Turk, you abomination," and springing up she slapped him on the face and tried to spit on it as well. In another instant she was being carried out in his arms like a child, he holding her away from his face and she trying to reach his head with her fists. "I will tell the French, I will tell the English," she was screeching. [...] Her language was such that the inspector ordered her to go away; but before the cabin had settled down she came back, and, sitting between two closely veiled Turkish women, she began to swear in Greek as an outlet to her roused passions. Among the epithets with which she was honoring the Turkish women beside her was the word "prostitute." [...] She managed to fire a last shot at an old-fashioned elderly Moslem lady who had been very quiet throughout the whole scene. "Dirt and abomination of the Christians, you dog of a Moslem," she cried. The old lady gasped and fainted. (Ordeal 7-8) ${ }^{64}$

The episode highlights a crucial moment of passage from the late Ottoman ways of defining Otherness to the development of Othering strategies proper of Turkish nationalism. At first sight, the difference between upper-class Turkish women, like the narrator, and the Greek agitator seems to be configured in terms of class, religion and ethnicity, and to reflect the classic Othering strategies of the Ottoman elite. In the classical age of the empire, Ussama Makdisi confirms, "religion and ethnicity were crucial makers of difference in the Ottoman system - they helped define what it meant to be an Ottoman: a member of the ruling elite, urban, above all aware of multiple ethnicities." Yet, Makdisi continues, being Ottoman entailed a "fusion of privilege, urbanity, class, patronage and Sunni Islam" (773); therefore, class was also a crucial criterion determining inclusion and one the narrator is aware of.

64 It is of course impossible and beyond the point of this study to assess the historical accuracy of this event, as well as whether such behaviors were as widespread as Edip wants her reader to believe. I am inclined to consider the ferry anecdote, as the autobiography as a whole, a product of fiction. Either way, it is noteworthy that the anecdote expresses a fierce resentment towards the Christian minorities of the empire. The target of the narrator's evident scorn and outrage is not the woman in yellow alone - who may or may not have existed and may or may not have behaved in this unseemly fashion but the entire category of "Christian women" who allegedly disrespect the institution of the ferry. 
Yet, Edip's description of the colonial Other is complicated by a phenomenon typical of the last years of the Ottoman Empire, one that Selim Deringil, in his influential article "They Live in a State of Nomadism and Savagery: The Late Ottoman Empire and the Postcolonial Debate," calls "borrowed colonialism" (314). In the $19^{\text {th }}$ century, Deringil argues, the Ottoman elite adopted the mindset of their enemies, the Western imperialists, and began to apply Othering strategies proper of Western colonialism to their own imperial subjects, describing them as having a "wild nature," "living in a state of savagery," and "only deserving contempt" (Deringil 317). Even though Deringil refers principally to the Ottoman periphery as the main target of 'borrowed' Othering strategies, Edip's autobiography proves that similar Othering practices targeted the Christian residents of Istanbul as well. Christian women on the ferry are described as animal-like, barbaric, and uncivilized: a "violent-looking rabble [...] who swarmed the firstclass cabin." The Greek troublemaker dresses in an inappropriate manner, she wears "brilliant yellow" garments, while it was considered advisable for women of the upper classes to wear black. She acts in a violent and unrestrained way, giving vent to her "roused passions" by swearing horribly at the other passengers. The text underscores the enormous distance between the "violent-looking rabble" of Christian women and the modest-looking, properly-behaved Turkish women: a distance that is dramatized by the short exchange between the Greek woman and the "old-fashioned elderly Moslem lady," who is so overwhelmed at the insults directed at her that she faints. In addition, minorities are addressed as childlike and requiring constant monitoring, as demonstrated once again by the narrator's description of the Greek woman, who the controller carries away "like a child."

The ferry scene in Edip's text is an example of "borrowed colonialism." The incompatibility of subject populations with modernization and technology is another crucial point and the focus on ferries is in fact hardly a coincidence. When Sultan Abdulhamid II issued a memorandum containing a series of measures to ensure the modernization of the provinces of the empire, means of transportation were of central importance. According to Deringil, public transport was equated with modernization and Westernization, and represented an important aspect of a "somewhat naïve civilizational mission" the Ottoman elite meant to carry out in the province (Deringil 320). The fact that the Christians of Istanbul could not internalize the behavioral code required on such items of progress as ferries and busses confirmed that their barbarism was unredeemable. Support for this interpretation comes from the insistence, on Edip's part, on how Istanbulite Christians could not come to terms with the functioning of means of public transportation. Another 
passage in Ordeal shows an Armenian bus conductor "taking the Christian women in and pushing the Turkish women out," a practice that caused much distress as "if [the poor women] failed to get on [they would] have to pass through unsafe and dark streets in order to reach their homes" (Ordeal 18). The Armenian conductor who had exposed Turkish women to potential violence in the dark streets of the city is finally scolded and dissuaded from persevering in his unprofessional behavior by a "big manly" Turkish police officer, who "found the courage to stand for a Turkish woman whom he did not even know" (18).

If on the one hand Armenians and Greeks are described as incapable of adapting to the civilized, urban environment of Istanbul, Turks, on the other hand, are impeccably-mannered models of self-control and urbanity. Men are virile ("big" and "manly," 18), good-natured, and compassionate, women modest and aristocratic. In the last phase of the empire, the awareness of a profound difference between the ruler and the ruled, drawing on the European colonial experience, replaced more malleable boundaries between the elite and the non-elite that had characterized the Ottoman Empire before its modernization. Starting from the $19^{\text {th }}$ century, Deringil and Makdisi argue, the Ottoman rulers appropriated Western Othering strategies as an unprecedented enforcement of the imperial center was needed in order to compete with the European empires and avoid being relegated to a subaltern position. This late-empire racialism (Makdisi 770) was rooted in the Western Enlightenment and re-cast the 'white man burden' philosophy in an Ottoman context, where Turkish tutelage was needed in order to lead the imperial provinces from a pre-modern condition of barbarism into modernity.

The description of the Christian Other emerging from Edip's ferry scene is clearly informed by late-Ottoman Othering strategies, but it simultaneously shows how these are being hybridized by a nationalist ideology in the making. Especially in the episode involving the ferry, Edip's autobiography laments the incompatibility of 'barbarism' and 'civilization,' represented in the text by Christian minorities and Turks respectively, as well as the failure of the Ottoman mission civilizatrice. In other words, Edip makes use of the late-Ottoman rhetoric of power, but there is no trace of an imperial civilizational mission any more. Therefore, the arguments that were once used to legitimize Ottoman rule over subject populations continue to be employed with a different purpose, namely, to vouch for Turkish national independence and sovereignty over the Anatolian territories that had been occupied by the Allies.

Although I had watched the scenes of violence in the cabin with self-control, the atmosphere of the deck began to stir me very strangely. Here were the poorer women, dressed in loose black charshafs, their faces always unveiled. I found their quiet ways 
very soothing, and they always made a place for me to sit among them. But in spite of this apparent calm I was becoming conscious of something subtle and penetrating about them. They did not talk much; still, I felt that they were profoundly affected and sad. They were neither articulate nor demonstrative, yet one could see that they had a sense of the doom of the Turkish nation; in fact, contact with the masses in Turkey made one feel that the doom of total extermination decided on by the powers was tangible enough to be felt by the simplest among them. (8)

This passage further illustrates the urbane, composed behavior of Turkish women, independent from social extraction. Moreover, Edip's benign description of women of the lower classes sitting on the deck confirms that difference in Edip's text is not so strongly articulated in terms of class, but principally along ethnic and religious lines. The bond felt by the extremely class-conscious narrator with the "poorer women" on the deck signals that Ottoman markers of difference are shifting and a sense of national belonging on an ethnic basis is starting to emerge. Most importantly, the narrator and the other women passengers are united by "a sense of the doom" looming over "the Turkish nation." In spite of the clear reference to a nationalist mindset in the mention of a "Turkish nation," the sense of doom is not merely a product of the military occupation of Anatolia, but also, and in the same measure, of the failure of the Ottoman imperial mission.

The fact that Ottoman ways of configuring difference may partially coalesce with Turkish nationalist Othering strategies is not new in itself. "Subaltern studies as well as authors such as Benedict Anderson and Timothy Mitchell," Deringil argues, "inevitably see nationalism as something that follows European colonialism. In the case of the Ottoman 'borrowed colonialism' we have something that develops side-by-side with it" (314). Here Deringil specifies how, in the Turkish context and in the last decades of the empire, colonialism and nationalism can be envisioned as two parallel phenomena: this parallel appears in Edip's The Turkish Ordeal as well. More specifically, the ferry episode shows that Edip's autobiography embodies the overlapping of imperial and nationalistic Othering strategies. The same arguments employed by the imperial elite to justify its rule over the empire's subject populations are appropriated by Edip to denounce how Turks a civilized and modern people - are denied sovereignty over Anatolia and forced to suffer humiliation at the hands of their former subjects. It is now appropriate to conclude with some further remarks on how Edip's ferry episode renegotiates categories of inclusion and exclusion, East and West.

While emphasizing the unbridgeable difference between Ottoman elite and Christian subject populations, Edip also highlights a series of affinities between Turkey and the West. She does that, firstly, by defining difference in a way that draws on how European colonialist states represented their colonial subjects, 
and by Orientalizing the subject populations of the empire according to the very principles of Western Orientalism. Secondly, Edip presents her narrator and the Turks as models of urbanity and progress. To Edip's Western readership, who was likely to find the narrator of The Turkish Ordeal very similar to upper-class ladies in the West, or to the heroine of a Western novel, ${ }^{65}$ the occupation of Turkey might at that point have looked paradoxical. Edip's powerful description shows Western readers that the Allied powers in Anatolia were not containing the insurgence of a barbaric empire, but severely limiting the independence and sovereignty of a perfectly humane population, formerly committed to a similar civilizing mission. Thirdly, Edip constructs Turkish modernity as informed by Western notions of progress, technologization, urbanity, and the rise of a national conscience. Edip's desire to look Western to Western readers comments on Turkey's "indecisive relationship with Europe" (Helvacioğlu 516). In spite of her fierce opposition to European colonialism, the narrator harbors mixed feelings towards the West, ${ }^{66}$ as it is typical of Turkish nationalism, which configures the West as "both the enemy and the object of desire" (Helvacioğlu 518).

Edip's ferry can conclusively be regarded as a space that exposes the conflict between Muslim Turks and the Christian minorities of the empire. Christians are Orientalized according to the 'borrowed' canons of Western Orientalism and therefore depicted as backward, beastly, and unaware of codes of behavior that regulate life in a Westernized, urban environment such as Istanbul. The ferry functions in this context as a metonymy of progress, an item that reflects, on the one hand, how effectively the empire has been modernized by its Ottoman rulers and, on the other hand, how ineffective the empire's civilizing mission proved in the case of Ottoman Christians, who remained in a state of 'savagery'. On the ferry, the very notions of East and West are, once again, re-negotiated: this time Edip's narrator casts Greeks and Armenians as part of a backward Orient, while collocating Muslim Turks in a Western narrative of rationality and progress. As I established in the previous section, however, the narrator also branded the Ottoman minorities as part of the Western imperialist project. Interestingly enough, the position of the minorities is highly ambivalent and always antipodal to Turkey: Western when Turkey sides with America (which, as the previous section suggested, occupies an idiosyncratic position within the 'West'), Eastern when it identifies with Western narratives of progress.

65 Adak reminds us that Edip's autobiography closely follows the Western tradition, which "narrates the development of a 'Self' moving from childhood or naïveté to gradual maturation" (Adak 518).

66 None of this ambivalence, however, affects Edip's representation of the United States. 


\section{Ferries Rewritten: Elif Shafaks "Life in the Islands"}

Shafak's article "Life in the Islands," published on Turkish Daily News in 2006, offers a very different perspective on the role of ferries in relation to diversity in imperial and post-imperial Turkey. The article focuses on the relevance of the Istanbul islands - Büyükada, Heybeliada, Burgaz, and Kınalı - in today's cultural imagery. The islands appear as a "sanctuary [of] inner peace and tranquility," but most importantly they embody "an ages-old, deeply-rooted cosmopolitan culture and a way of life that Istanbul [...] has long lost" (Shafak, "Islands" n.p.). The ferry to the islands share the same connotations.

The first hints of that culture are revealed on the way to the islands, in the ferryboats that commute back and forth between the city and the four islands. There, you will encounter a variety of people, a motley cluster of individuals from all walks of life, and hear a variety of languages and idioms, being spoken all at once. Greek and Jewish, Armenian and French, English and Ladino will intermingle with Turkish. Every now and then you will hear a sentence that had started in Turkish to be completed in Jewish. Sometimes a talk in Turkish will be replete with Armenian expressions. You will hear them all. You will happen upon mothers who speak French with their children, Turkish with their husbands. You will see women who enthusiastically, unreservedly and almost endlessly gossip in one particular language, but then choose another language when they want to "get serious." Next to these seasoned islanders, most of whom have either been born on the island or spent most of their childhood and adolescence here, you will catch sight of the visitors - Istanbulites of all professions, here for a daily escapade from the hustle and bustle of the city, and numerous tourists, composed of mostly Arabs, British, and Russian. The Arabs come with their families, children and all, the British come with their partners, couples holding hands, and the Russian come with their dreams. All are welcome in the islands. ("Islands" n.p.)

Once again, ferries stage the interaction among different ethnic groups, who find themselves sharing a restricted space where difference is magnified. Yet this time the scenario is radically different: one immediately realizes that, on the ferry, class and ethnic difference is celebrated and exhibited. Shafak, writing in English for both Turkish and non-Turkish readerships, proudly presents ferries as spaces where a miniaturized image of Istanbul's "gracefully intense and vivid cosmopolitan culture" ("Islands" n.p.) can be experienced. Edip's and Shafak's ferries are both predominantly feminine spaces. In Shafak, however, the emphasis on women, children, couples, and families conveys the vision of a reassuring environment devoid of conflict, where passengers of all classes and ethnicities interact amiably. Women from different social backgrounds, creeds, and ethnic groups relate to each other by "enthusiastically, unreservedly and almost endlessly gossip[ing]" ("Islands" n.p.), a statement that sets Shafak's ferry in a stark 
contrast with Edip's, permanently staging ethnic, religious, and class conflict, especially among women. Edip resorts to late-Ottoman Orientalism to bolster the argument that Muslim Turks are the most suitable to govern post-empire Anatolia and singles out the poor behavior of a Greek woman on a ferry as evidence of the mishandling of power in the hands of underserving, improvised oppressors.

More than eighty years after the foundation of the Turkish republic, Shafak rewrites the significance of the Bosphorus ferry and turns it into a vehicle for a critique of Turkish nationalism, the very ideology Edip promotes in her own ferry anecdote:

And you will lament the gradual loss of this astonishingly, gracefully intense and vivid cosmopolitan culture, once present in almost every nook and cranny in Istanbul and Turkey, but now confined to particular spots and those only. Turkey has lost countless minorities in its recent history - so many non-Muslim families have left this country, step by step. Though they are gone, from each and every family something remains behind - remnants of a past not that far away. As it has moved away from being a multilingual, multiethnic, multireligious empire towards a secular, modern nation-state, it is indeed true that Turkey has accomplished a major transformation unheard of in other regional contexts. And yet the flipside of this story is that a gradual loss of cosmopolitanism has accompanied Turkey's recent political history. [...] It is time to learn not to be afraid of differences - be it ethnic, religious or cultural, and celebrate, once again, multiculturalism. ("Islands" n.p.)

Shafak's text acknowledges the Republican years as a period of progress and advancement, but it mostly expresses concern for the "flipsides" of nationalism: most notably, the disappearance of Ottoman multiculturalism, replaced by policies of assimilationism to an exclusively 'Turkish' national identity, and the rupture with the country's imperial history and tradition.

A crucial aspect that characterizes Edip's and Shafak's ferry scenes as antipodal is the approach to the Christian minorities of the empire. "Turkey has lost countless minorities in its recent history," Shafak writes, "so many non-Muslim families have left this country, step by step. Though they are gone, from each and every family something remains behind - remnants of a past not that far away" ("Islands" n.p.). Shafak denounces the effects of nationalist discrimination that led non-Muslim minorities away from Turkey. Thus, after having been the object of Edip's contempt, Greeks and Armenians are now regarded as part of Turkey's multicultural identity and mourned as an overwhelming absence. The ferry on the Bosphorus and the islands around Istanbul stand as mementos of a forgotten past, and, by the same token, remind Turks that reconciliation and coexistence are indeed possible. 
The analysis of ferries in this chapter can be read in the light of cultural mobility theory. The goal of mobility theory is, in fact, to transcend the dichotomy between "transport research and social research" and to "connect different forms of transport with complex patterns of social experience" (Buchenau 56). The ferry space enables "complex connections to be made, often as a matter of social (or political) obligation" (ibid.): the travelling crowds on Edip's ferry are forced into coexistence and this reluctant proximity re-enacts larger social dynamics in a miniaturized space. In Shafak, the fortuitous encounter of people on a ferry recreates the conditions for the cultural intermingling that characterized the Ottoman classical age. The role of ferries in Turkish American literature fits easily with Greenblatt's understanding of mobility theory as an instrument that connects "literal movement" with the "exchanges, interactions and the flux that are at the core of literature and culture" (Greenblatt in Buchenau 57).

\section{Little Stories of Independence: Orphanages}

Orphanages are also involved in the process of rewriting Turkish history from a nationalist perspective into a multicultural one. Often operated by American institutions such as the Near East Relief, orphanages were theatres of ethnic conflict in the years following the collapse of the Ottoman Empire and appear in both Edip's The Turkish Ordeal and Shafak's The Bastard of Istanbul. Once again, Edip's and Shafak's representations of orphanages reveal telling differences and similarities. The main differences stem from the antithetic ideologies informing the two novelists' works - nationalism on the one hand, multiculturalism and neo-Ottomanism on the other. The similarities, instead, revolve around the attempt to construct subversive historiographies that downsize the male-singular experience and the historiographical practices that constructed Turkish history around the figure of Mustafa Kemal Atatürk, coalescing, in Hulya Hadak's words, the man and the nation (Adak 516). In both cases, these historical accounts are written in English and placed on an international market.

The representation of orphanages in Edip's memoirs has already been addressed in this chapter. In her discussion of the poor management of orphanages in the interstitial years between the fall of the Ottoman Empire and the birth of the Republic, Edip denounces Armenians as exponents of a deviant form of Christianity, subjecting Turkish children to barbaric forms of conversion. "[T]he Armenians," Edip reports, "were not content with occasionally wrestling a Turkish child from its nationality; they wanted every child brought there to be pronounced an Armenian without exception. So far even the American missionaries could not go in their Christian zeal" (Ordeal 13). Edip casts abused Turkish children as a symbol of the 
oppressed Turkish nation, struggling to retain its sovereignty and identity. The following passage illustrates the dramatic effort of a Turkish child, Kiazim, to resist conversion.

A Turkish boy called Kiazim, from Adana, had been taken as an Armenian but did not submit easily. The boy was the son of a Turkish official in Adana. His father had died. As he had no mother either [...] the boy was pronounced Armenian. He had stuck to Nakie Hanum, crying and begging to be saved. But the commission was obdurate. Then the boy had stood up and said, "Kiazim is small, Kiazim is weak, his fists cannot protect him, but the time will come when Kiazim will be strong: then he will show the world that he is a Turk." $[\ldots]$ The pain of the little creature affected me strangely $[\ldots]$. To me he was a symbol of the helpless Turkish nation at the moment. He had been small and weak. (Ordeal 13-14)

Besides women, Edip also integrates children in the Turkish nationalist cause. The narrator establishes a parallel between children and armed resistance (stressed by the fact that Kiazim's father was a Turkish officer) and praises Kiazim's promise of vengeance against his Armenian tormentors, once his fists would have grown into those of a soldier. Not only does the narrator celebrate Kiazim's resistance, she identifies with it. Kiazim's touching story embodies her frustration with the amount of power the Allied bestowed on the former imperial minorities, who, in her view, plotted to annihilate their former Turkish rulers. Not only does Kiazim rise as a symbol of his country, helpless and vulnerable in the hands of the Christian minorities (but nevertheless conscious of its superior physical and moral strength), the little boy's story also exemplifies a deeply rooted rivalry between Turks and Armenians, which escalated with the birth of an Armenian national movement and the Armenian genocide. The narrator designates a passionate child, the emblem of innocence and honesty, as a champion of anti-Armenian resentment. By doing so, the struggle for the preservation of Turkish identity and independence emerges as a most justifiable cause, one even children understand.

In spite of her focus on the oppression of Turkish children, the narrator of The Turkish Ordeal also states that "these orphanages had taken Armenian children as well and made them Moslems," but rushes to clarify that this "was wrong" (12) and immediately adds that "some Turkish families had taken Armenian children out of kindness and pity and without any desire to make them Moslems" (12-13). In The Bastard of Istanbul Shafak offers a different portrayal of orphanages, as she focuses on Armenian children being converted to Islam. The most salient difference, as previously mentioned, is in the two novels' contrasting ideological priorities. If Edip's work concentrates on the establishment of Turkish national identity, Shafak's concern lies with the rights of the Ottoman minorities. The 
Bastard of Istanbul gives prominence to the conversion of Armenian children to Islam and references to the reverse process are nowhere to be found.

Shushan Stamboulian, later renamed Shermin KazancI, is an Armenian child who, after having lost her family to the Armenian genocide, is brought to an orphanage. In the orphanage she is given a Muslim name, Shermin, and a number, 626, emphasizing the feeling of de-personalization and uprooting that followed the children's permanence at the orphanages. Unlike Kiazim, Shushan/Shermin accepts conversion for the sake of her own survival, but she will undergo a delayed awakening to her real name and ethnicity later in life, after marrying a Turk and becoming a mother. The following lines show that Shushan/Shermin preserves the memory of her Armenian family, represented by a pomegranate brooch, throughout her life as a Muslim.

Shushan never forgot the pomegranate brooch. Not when she dropped half dead on the road to Aleppo and was left behind; not when the Turkish mother and daughter found her and took her into their house to heal her; not when she was taken by bandits to the orphanage; not when she ceased to be Shushan Stamboulian and became Shermin 626; not when years later Riza Selim Kazancı would fortuitously chance upon her in the orphanage and [...] decide to take her as his wife; not when she would the next day become Shermin Kazanc1. (The Bastard 324)

Through the story of Shushan/Shermin, converted to Islam and reintegrated into society as an obedient Turkish wife, Shafak denounces the late-Ottoman and Kemalist policies of discrimination against former imperial minorities, and the practices through which they were assimilated into an idea of Turkishness that underpinned the creation of an ethnically homogeneous Turkish nation. As political scientist Yilmaz Çolak explains, "the Turkish reformers' main intention was to end the Ottoman multicultural and multinational legacy and melding all differences under the name of Turk" (591). Such process granted Turkish citizenship to non-Muslim minorities such as Greeks, Armenians, and Jews as well as to Muslim immigrants from the former imperial territories. In spite of the apparently generous extension of Turkish citizenship to different ethnic groups present in Turkey, Robert L. Daniel deems Kemalist nationalism as exclusive and xenophobic (Daniel 54-55). He explains how, in the first years of the Republic, non-Turkish doctors were denied their license, while in schools all over the nation history, geography, and civics had to be taught by Turks, in Turkish, and from Turkish textbooks (Daniel 55). Finally, Ömer Taşpinar points out that "the new Turkish Republic recognized non-Muslims as Turkish citizens but engaged in a de facto discrimination against them" (Taşpinar 5). The superficial inclusion of former imperial minorities into the category of Turkishness coincided 
therefore with severe limitations of the minorities' civic liberties, driving most of them on diasporic itineraries away from Turkey.

Shafak warns her readers of the dangers connected to the homogenizing, assimilationist approach of Kemalism. Years after her forced conversion, Shushan/ Shermin drastically severs the bonds with her Turkish family after rediscovering her Armenianness, a gesture her husband interprets as a betrayal. Most importantly, the novel suggests that her destiny, forced conversion, and ultimately, departure, brought a curse on the entire Kazancı family, one that will prematurely kill its male members for many generations to come.

As in the case of ferries, Edip describes orphanages as sites where Armenians convert Turkish children to Christianity, thus weakening Turkish identity. By contrast, Shafak gives more visibility to the conversion of Armenians to Islam. The significance of orphanages in the shaping of Turkish identity varies greatly in the two accounts. On the one hand Kiazim's story exposes practices of forced conversion perpetrated by Armenians on Turkish children. Kiazim's resistance towards conversion elevates him to a symbol of the Turkish cause. Through Shushan/Shermin's story, instead, Shafak denounces violence perpetrated on the Armenian population, and shows how it affected the future of Shushan/Shermin's Turkish family as well as her own. She also warns that the legacy of the Armenian genocide is going to reverberate negatively on the future of Turkey, should the government not relinquish its negationist position. Shafak's treatment of orphanages connects effectively with her advocacy of multiculturalism in Turkey as an alternative to the failures of nationalism, which she deems responsible for the rupture between Turks and the minorities of the empire, and between modern Turkey and its Ottoman history.

Surely readers are provided with a variety of contradictory representations of missionary enterprises in Anatolia. An article by Armenian American activist and writer Aghavnie Yeghenian in the New York Times provides further evidence as to how these accounts differ. Motivated by widespread enthusiasm about the figure of Edip in the United States, Yeghenian's article is an outraged revision of Edip's role in the War of Independence.

She $[\ldots]$ had charge of a vast numbers of Armenian orphans [...]. So this little woman who so often boasts of her American ideals of womanhood [...] after her calmly planning with her associate [i.e. Jemal Pasha, considered one of the masterminds of the Armenian genocide] forms of human tortures for Armenian mothers and young women undertook the task of making Turks of their orphaned children. The allies knew of her complicity in these crimes [...]. (Yeghenian n.p.) 
In Yeghenian's description of orphanages, Armenian children were assigned Turkish ethnicity. Not only does Yeghenian contradict Edip's account, she also accuses Edip of playing an active role in these 'conversions' and of torturing Armenian women.

These obscure and contradictory representations of American orphanages in Anatolia during the War of Independence demonstrate that orphanages were sensitive spaces where a new national identity was being defined. This negotiation of identity happened on a practical level - as the orphanage authorities forcibly converted children and ethnic identities were sometimes arbitrarily assigned - but also on the level of literary representation. The divergent depictions of orphanages presented in this section show how different ethnic groups claimed space, autonomy, and recognition within the new republic, struggling to define their roles, Othering and being Othered in turns.

The fact that orphanages were run by Americans is not without relevance. Firstly, Americans appear as silent but omnipresent witnesses of ethnic conflict in Anatolia. Secondly, by addressing their accounts to American audiences, Edip and Shafak assign America the role of the ultimate judge on issues that concern local politics and ethnic struggles. All of these accounts seem to expect, demand, or hope that America may intervene, supporting one claim to sovereignty or the other. Edip calls on the American missionaries to condemn the cruel treatment of Turkish children and share the Turkish cause; in The Bastard, Shushan is eventually rescued by her brother and taken to the United States; Yeghenian implies that Edip has abused the American values she had absorbed in her formative years, and interrogates her American audience: "Is this the ideal of American education which we wish to impart to the new generation of Turkish women?" (Yeghenian n.p.). Ultimately, Edip's and Shafak's pleas for American acknowledgement reveal a more or less explicit desire to shape Turkish national identity along the lines of American thought and values.

\section{Towards Ottoman Sisterhood}

In spite of the substantial differences dividing Edip and Shafak, it is still possible to claim that the two share considerable similarities, and it would be legitimate to envision Shafak's writing as indebted to Edip's. Shafak doubtlessly writes back to Edip's nationalist imagery, reverting and rewriting it into a discourse of multiculturalism and reconciliation. Yet, in their English publications, both Shafak and Edip fiercely advocate what Mike Featherstone calls "the lesser tradition of history, the suppressed history of outsider groups such as women [and] ethnic minorities" (Featherstone in Çolak 588). Both Edip's and Shafak's works are highly 
critical of the Kemalist vision of history, a national myth constructed around the figure of a male leader.

Edip, although a vocal supporter of Turkish nationalism at first, questions the Kemalist doctrine on many levels. Towards the end of Ordeal, the narrator recedes from her racialist standpoint and realizes that all former Ottoman subjects, independently from creed and ethnicity, are united by common suffering. The mutated attitude towards Christian minorities, especially women, is striking, since the way Ordeal ends contradicts its beginnings:

Two young Greek women sat on the ground on each side of the old woman, reclining on her knees in a consciously graceful attitude. "Do come this way, Kirya," called out the old woman in Turkish. The next moment she was telling me her story, seasoned with most obvious flattery for the Turks and for myself. (277)

I could visualize the tragic scene at the station where the Turkish girls were dragged off and violated in public. "Were there no Greek officers who could stop this criminal lunacy?" I asked. She answered, "Yes, two of them shouted frantically: they fired at the men, and it is due to them that I escaped..."Well, it is those two officers who represent for me a Greece which lives and prospers and has a place in the world. (305)

The first excerpt differs enormously from the ferry episode analyzed earlier in this chapter. At this stage, Greek women appear capable of behaving gracefully and respectfully towards the Turks, as emerging from the older woman's kind invitation to the narrator to join them, and from her willingness to open up and "tell her story" to her Turkish interlocutor. The insults targeting Muslim women on the Bosphorus ferry feel very distant from the gracious appellative "Kirya" (madam), with which the Greek woman addresses the narrator. The narrator herself seems apologetic and invested in constructing an inter-ethnic sisterhood that was nowhere to be found on her ferries. The second excerpt, instead, counterbalances the initial bus episode, where an Armenian conductor indirectly exposes Turkish women to violence and abuse by not letting them on his bus and forcing them to walk home alone at night. Here, conversely, two Greek officers save the honor and, possibly, the life of Turkish women. Ultimately, the responsibility for the war is lifted from the shoulders of the Christians: "I was very sorry for the irresponsible ${ }^{67}$ Greek population who were uprooted from their homes and often made to pay the price of the blind nationalism of the Greek politicians, or of the perfidious policy of the Allies who had launched the Greeks into

67 "irresponsible" is to be read, presumably, as lacking responsibility. Yet, the narrator is not unfamiliar with the practice of infantilizing the former imperial subjects. In this light, the term could also be interpreted as clueless, or 'not able to bear responsibility.' 
this ugly adventure" (Ordeal 305). The Greeks ultimately emerge as the victims of Western scheming, a fate they share with the Turks and the other minorities. In Ordeal, the solidarity among Muslim and Christian subjects of the empire in the face of suffering and death gestures to the intrinsic validity of an 'Ottoman' identity. The newly-found unity among ethnic groups inhabiting the Anatolian peninsula, in fact, obliterates the need for the ethnic purism of Turkish nationalism, reconfirming Ottoman multiculturalism as the foundation onto which a post-imperial identity can be constructed. ${ }^{68}$

As the two excerpts demonstrate, along with the ferry and bus episodes, individual stories of women are central to Edip's autobiography. Firstly, women are the 'privileged' witnesses of the Turkish war of Independence and they are invested with enormous responsibility: with the men gone to the front, it was their task to "keep themselves and the country alive" (Ordeal 249). Secondly, personal stories of women and children on the ferries, in the orphanages, and in the devastated villages of Anatolia accompany the narrator's trajectory from Kemalist nationalism to a renewed faith in Ottoman multiculturalism as the basis for national identity. The inclusion of minorities in the process of history- and identity-making in Turkey does not make Edip's nationalist fervor vacillate. Yet, the nationalist narratives articulated in the course of Ordeal dismantle those of Kemalism. They do so by configuring the nation not as one imagined community requiring ethnic and religious assimilation, but as a plurality of imagined communities where definitions of self, Other, nation, and minority are in a constant process of revision and negotiation. Through the several individual stories presented in Ordeal, Edip retraces moments in which "particular individuals had power (or were powerless) to redraw (or remake) national categories of belonging or exclusion" (Mills 396). Amy Mills would categorize Edip's nationalism, one made of personal stories and memories, as an "embodied nationalism" (ibid.) in which everyday life and individual identities invalidate state-authored identitarian narratives.

Ottoman solidarity and the feminine perspective on history are central themes in Shafak's writing as well, and the story of Shushan/Shermin confirms

68 Edip's celebration of Ottoman sister- and brotherhood is not an innovative concept. Quite the reverse: it is rooted in late-Ottoman, Tanzimat mentality. "Beginning with the Tanzimat," Makdisi argues, "Ottoman reformers identified with [Ottoman subjects] as potential fellow citizens with whom they should be united in a newly defined modern Ottoman patriotism. They also saw them as fellow victims of European intrigue and imperialism" (Makdisi 770). Still, in Edip's narrative, this late Ottoman cautious openness towards multiculturalism prevails over the paradigms of Kemalist nationalism. 
the assumption that Turkish nationalism disrupted the intrinsic solidarity of Ottoman populations. In The Bastard of Istanbul, the narrator briefly mentions that a Turkish woman and her daughter rescued Shushan/Shermin from the street where she collapsed and welcomed her into their house, where they healed her (324). Only later did bandits take Shushan/Shermin to the orphanage where Riza Selim Kazanci found her. The succession of events suggests a clash between a sisterhood of Ottoman women, represented by the Turkish women helping an Armenian little girl with no regard to race or creed, and the disruptiveness of male intervention, symbolized by the bandits (in all likelihood male bandits) and especially by Riza Selim Kazanc1, who, in good faith, finalizes Shushan's assimilation to the Turkish homogeneity sponsored by Kemal's nationalism.

\section{Women and Children First: Founding a 'Subaltern' Religion}

The representation of Islam offers one more occasion for a comparative analysis of Edip's and Shafak's work, validating the continuity of concerns and imagery in Turkish American literature. The process of reconstructing history giving prominence to feminine voices, repressed or marginalized by patriarchal historiography, also extends to the realm of religion, whose capacity to relate to the female sensitivity is often questioned. Another area where Shafak's and Edip's works overlap is in fact the destabilization of the Koran's male-centered perspective and the renegotiation of women's space within Islam. Edip's and Shafak's 'rewriting' of Islam from the perspective of women lays the basis for the deconstruction of a series of simplistic images of Turkish womanhood that informed the Kemalist discourse, namely, as Zehra Arat suggests, either as "a secluded and inert mass oppressed by the harsh patriarchal rules of Islam," or as "liberated by and living within Mustafa Kemal's Atatürk's secular state” (Arat 4).

Remarkably enough, Edip's and Shafak's rewriting of Islam, which aims to reconsider and expand female subjectivity, coincides with another, parallel project that establishes a compelling connection to the goals of my study. For both writers, rewriting Islam corresponds to bringing it closer to a Christian readership, and to the establishment of a transatlantic connection with a specifically American context. By proposing a Christian reading of episodes and figures of the Koran (Edip) or through the constant effort to create an image of Islam that talks back to post 9/11 Islamophobic discourses (Shafak), the two authors carry out a 'domestication' of Islam that aims, as Said puts it, "to cancel, or at least subdue and reduce, its strangeness and [...] its hostility" (Said 87). The following section provides evidence that while Edip and Shafak renegotiate the space of femininity within religion, they also rewrite Islam within a specifically American frame. 


\section{Halide Edip: Rethinking Prophets and Fathers of the Nation}

While The Turkish Ordeal is a political text dedicated to undermining the hegemony of Kemalist historiography, the previous volume of Edip's autobiography, Memoirs of Halide Edip (1926), covers a more intimate dimension and, in the tradition of the Western bildungsroman, accompanies the narrator in her formative years. Yet, the two volumes have as common denominator the goal of "renarrat[ing] personal and cultural history through an alternative feminine voice" (Ghaussy 5). The narrator of Memoirs may differ widely from that of Ordeal, but both articulate unauthorized histories that dismantle the narratives of patriarchy.

In Ordeal, the male-centered perspective of Kemalist historiography is counterbalanced by multiple stories of women, so as to replace the masculine-singular subject of history with a feminine plurality. This process finds a correspondence in Memoirs, where the transmission of historical knowledge is de-masculinized through the figure of young Halide's tutor, Ahmed Aga. The figure of Ahmed Aga is meant to create a contrast with the narrator's previous tutor, a polygamous man who "classed his wives according to their capacity to cook pilaf" (Memoirs 114). Ahmed Aga appears as the representative of a non-normative masculinity: no mention of his marital status is given and the most salient trait of his personality seems to be his remarkable intellect. In the narrator's account, Ahmed Aga appears as "a short small man [...], dark, sly and intelligent, a man who could read and write and handle, or rather rule, his masters with psychological insight" (115).

From [Ahmed Aga] I got great deal of my early education. [...] It was by a mere chance that I fell under the influence of a man of his type, but it was this chance that opened to me the folklore, the popular Turkish literature. [...] I lived only when Ahmed Aga was reading stories. (115-116)

The stories the young narrator hears from Ahmed Aga revolve around the "epic, [...] long, bloody, and cruel" battles fought by male heroes $(116,117)$. Yet, in spite of the exposure to masculine heroism, the education in history and literature the narrator receives from Ahmed Aga is an intensely hybrid experience. His vision of history is one in which the oral and the written traditions, facts and imagination, historiography and folklore intertwine. Ahmet Aga's stories are drawn from history books, but are transmitted orally to the narrator, who is free to overlook the "meager historical facts" and fantasize on the "Oriental imagination" instead (116), choosing her own focus and perspective on the narrated facts. Edip's views on history are reminiscent of feminist theorist Trinh Min Ha's, who locates truth in hybridity, as "being truthful is being in the in-between of all regimes of truth" (Trinh 120). Ahmed Aga emerges therefore as the champion of a malleable 
notion of history, including the realms of tale, legend, myth, fiction, literature, the factual as well the fictional.

Thanks to Ahmed Aga's lessons, the narrator develops a fascination for what can be called a 'subaltern history', deliberately ignoring the perspective of male conquerors to concentrate instead on the subaltern: women, children, and the less privileged social strata. By shifting the focus from male heroes to women and children, Edip tries to construct history as the sum of multifarious experiences.

The book [on the Persian hero Abamouslin Horassani] seemed to squeeze my heart in an iron band, tightening it with the ugly passions and demonstrations of power of the famous heroes. I wondered all the time what the simple little children were doing when all this bloody and cruel struggle was going on in a country, whether they dared to go into the streets and play, and what sorts of nights they had and what dreams they dreamed. [...] Whenever I see or read of a great military hero performing his deeds, and of history or literature recording them, I wonder in the same way, not about the children only, but about the simple grown-up people as well. (118-119)

Not only does this recurring shift of focus from a hegemonic male perspective to a subaltern one bind Memoirs and Ordeal with significant ideological continuity, but it also extends from history into the realm of religion. Edip's construction of Islam obeys the same criteria guiding her rewriting of history, with particular emphasis on the role of women.

Edip's rewriting of Islam presents a movement from orthodoxy to heterodoxy, and from a patriarchal understanding of doctrine to a semi-matriarchal one which awards equally representative roles to male and female characters. One illuminating example for this are her considerations on a Sufi poem depicting Mohammed as a child, in the arms of his mother Emine.

It was perhaps my objection to the exclusiveness of orthodox Islamism which made me love the simple and beautiful birth poem of Mohammed by an early sixteenth-century poet of the mystic order of the Mevlevi - Suleiman Dede. [...] He makes Emine, the mother of Mohammed, describe the child, when only a few minutes old, as having its little face turned to the wall, its eyes full of tears, mourning and praying for the low and sinful who were destined to eternal fire. (159-160)

The significance of this poem can be articulated on two levels. One aspect involves the renegotiation of the space of the feminine within the patriarchal logics of Islam. By making Emine "describe the child," the poem invests a female figure with prominence, centrality, and the power of description. The second aspect is the characterization of the Prophet Mohammed as a vulnerable child in the arms of his mother. Deprived of the connotations of conqueror and father of Islam, 
Mohammed is caught in a situation of partial dependency on his mother's protection $^{69}$ and, above all, he appears as the object of her description.

Both aspects point towards the necessity to rethink the space of masculinity within Islam, in order to increase the presence of women as subjects and interpreters of doctrine. In other words, the symbolic and literal downsizing of Mohammed's masculinity in combination with the expanded figure, voice, and role of his mother hopes to "transform a century old silence into a presence of women and subjects in every aspect of existence" (Braidotti 266). For Sohelia Ghaussy, the act of "remembering the mother's body" - indeed what Edip invites religion to do via the Sufi poem she embeds in her narrative - goes into the direction of "resurrecting the lost memory of a female past [...] repressed through an aphasia and voicelessness concerning women's past experiences within patriarchal discourses" (Ghaussy 6). Again, the 'archeological' practice of retrieving a disavowed past gains unquestionable prominence in Turkish American texts.

The figure of Emine does not crush or annihilate that of her child; instead, she seems to act as a mediator, pointing towards him as well as towards herself as the no longer silent "groundwork of male subjectivity - the condition of possibility for his story" (Braidotti 266). Male and female agents in Edip's vision of Islam do not exclude each other - as Emine's tender maternity scene confirms - but are represented as complementary. The mother's body, enlarged and endowed with voice, gently focalizes the reader's attention on her child, which illustrates the interdependence and interconnectedness of the feminine and the masculine. The Sufi poem is therefore a fitting embodiment of Edip's subversive historiography, as in both her autobiographical volumes, to put it with Ghaussy, "women's voices indeed come to form the dominant discourse [...] without, however, constituting a dominating 'master narrative"' (Ghaussy 1$)^{70}$.

69 Mohammed is dependent, but not utterly helpless: depicted while praying for the "low and sinful," the Prophet seems to be already entitled to some form of agency.

70 It must be added that, although precious to the purpose of my argument, the Sufi poem and the use Edip makes of it in Memoirs is not as disruptive of patriarchal or Kemalist doctrine as the more poignant feminist discourse in Ordeal. Connected to the domain of motherhood and child bearing, the figure of Emine is still firmly lodged in Kemalist nationalism within which women did enjoy a greater measure of independence but were portrayed by nationalist rhetoric as strictly subordinated to male authority - as Durakbasa and Ilyasoglu point out, Kemalism defined women as "breeders and educators of the new generations, daughters of the republic, and enlightened mothers of the nation" (Durakbasa and Ilyasoglu 195). 
The renegotiation of the figure of the Prophet, represented as a newborn child, creates a compelling parallel to Ordeal and its relentless erosion of the myth of Mustafa Kemal as the prophet-like, superhuman father of the nation. In Ordeal, Edip exposes Kemal's "ambition for despotism" (Ordeal 12), describing him as histrionic, cowardly, "by turns cynical, suspicious, unscrupulous, and satanically shrewd" (128), prey to Napoleonic attitudes, and likely to cast Turkey into a "reign of terror" $(263,273)$. The focus of the Ordeal lies on the creation of a "human document" (132) that eradicates the personal myth of Atatürk, presenting the Turkish War of Independence and the birth of the republic as a collective effort instead of the achievement of one lone conqueror. To put it with Adak, Ordeal "emphasized the network of identities, the interdependence of leaders and people in the Struggle. Such a depiction of interdependence contrasts with the myth of the sole hero, the prophet of the republic, instead describing the republic as a collaborative effort" (Adak 520).

Memoirs and Ordeal are therefore united by the urge to rethink the role of fathers and prophets within historical and religious narratives of pluralism, where a multitude of marginal voices rise to complement and question patriarchal rhetoric. The marginalized experiences of women and children gain a position of centrality at the expense of the stature of male agents - from orthodox teachers of Islam down to Mustafa Kemal and Mohammed himself.

\section{Sufi Madonna with Child}

The implications of the Sufi poem with Emine as its protagonist go beyond the desire to restore the prominence of female characters. Its closeness to one of the most popular themes of Catholic and Orthodox ${ }^{71}$ religious iconography, the Madonna with Child, is very much in evidence here. I want to suggest that the significance of this poem in Memoirs develops into two parallel dimensions: it

71 Edip's representation of Christianity is very general. She hardly acknowledges the existence of several doctrinal dimensions within Christianity and blends elements from disparate Christian traditions. The image of Emine holding Mohammed is strongly reminiscent of traditional Marian art, typical of the Orthodox and Catholic Churches, but the characters of simplicity, sincerity, and asceticism arguably establish a stronger link to Protestantism. This is not surprising as American missionaries in Anatolia, although being Protestant, worked in close contact with Christians of several confessions, including Orthodox Greeks and Gregorian Armenians. It is legitimate to think that Edip, during the time at the missionary school, might have been exposed to heterogeneous Christian practices, hence, the boundaries between reformed and non-reformed Christian churches in her writing are sometimes blurry. 
renegotiates the space of women within Islam and simultaneously creates a connection to Christianity that reinforces the specifically American frame of Edip's autobiography.

The context in which the poem is embedded provides further evidence of Edip's search for common grounds between Islam and Christianity. The narrator's appreciation of the Sufi poem on Mohammed's birth comes as a response to Islam's incapability to satisfy some of young Halide's longings, expectations and concerns:

Islamism taught by an orthodox person is very clear and full of common sense, but like everything very orthodox it lacked a certain mystic emotion, and this led me to long as I grew older for the mystic tendencies of the dissenting spirit of the tekkes. ${ }^{72}[\ldots]$ I performed my obligatory Arabic prayers very carefully at the set times, but after each one I had a Turkish prayer, almost a talk, with Allah. I asked him mostly questions about the reasons which control men's cruel acts and thoughts, and about the position of the nonMoslems, which seemed to me the primary injustice of my religion. Why not the same measure of goodness and holiness for everyone? (158-159)

The excerpt suggests that orthodox Islam, like official historical narratives celebrating male military heroes and conquerors, is unfit for the sensitivity and most pressing concerns of a little girl. To the distant divinity of orthodox male teachers, the narrator prefers a God capable of universal love and compassion, democratically offering "the same measure of goodness and holiness [to] everyone" (ibid.), independently from their creed. Democratic forgiveness and universal benevolence are certainly virtues a Christian readership would approve of and identify with. Yet, it is not only a palatable version of Islam that Edip is offering her Anglophone readers: not only is she emphasizing the common grounds between the two religions, she is also carefully averting occasions of conflict, since what the narrator considers "the primary injustice of [her] religion" is "the position of non-Moslem" (ibid.).

Being aware of the narrator's "genteel racialism" (Makdisi 793) and frequent disparagement of Ottoman Christian minorities, one assumes that she mostly has Western Christians in mind when she expresses her tactful detachment from Islam's exclusion of non-Muslims from holiness and salvation. It is principally her "objection to the exclusiveness of orthodox Islamism" that drives the narrator to appreciate the verses of a Sufi poet and to embrace "the dissenting spirit of the tekkes" (158). Edip's own definition of tekkes, described as a "Moslem institution, something of the character of Christian monasteries," hosting dervishes of

72 Buildings where Sufi brotherhoods gather to worship. 
"non-orthodox mystical tendencies" (ibid.), is an example of her investment in creating a parallel between Christianity and Islam, and in familiarizing Islam for Western audiences. She does so most prominently through the theme of Sufism, a mystical current of Islam that she sees as closest to the New Testament message of Christianity, or at least to her understanding of it. Duygu Köksal confirms this assumption when she affirms that Edip categorized Christianity with the Sufi tendency of Islam, due to its simple and sincere representations, and its ascetic and monastic features (Köksal 88). Köksal also defines Edip's Islam as contemplative, pacific, and feminine, with a pronounced universalist vocation (87). Erdağ Göknar also underscores this function of Sufism in Edip when he writes that Edip "rel[ies] on Sufism as a dominant trope to manage cultural paradoxes" (Göknar, Orhan Pamuk 152).

Most importantly for the purpose of this analysis, Başci traces a direct connection between Edip's writing and the work of American missionaries in Turkey, reiterating that Edip went to the American school for girls in Üsküdar, Istanbul, and that her literary success had been later instrumentalized by the missionary propaganda to demonstrate the beneficial impact of American missions in Anatolia. "Among the achievements missionaries considered to be their very own," Başci explains, "Halide Edip - her personality and work - almost always topped the list" (111-112). In light of recent observations, and considering the specific American imprinting Edip received in her youth, the "religion axis" theorized by Köksal to illustrate how Edip's notion of Islam "transcends the East-West dichotomy" (Köksal 87) can be narrowed down to a Turkey-U.S. axis.

\section{Undermining Myths of Masculinity and the "Threat of Islam": Ali's Religion of Love}

Ali, Prophet Mohammed's son in law and central figure to Shia Islam and Sufism, represents another instance of how Edip challenges the canons of mainstream masculinity and virile heroism, simultaneously establishing a compelling connection with Christianity. The passage where the narrator expresses her sympathy for Ali, a chivalrous, gentle hero, is preceded by familiar considerations on history and his protagonists:

the fighters of great battles, the slayers of men, even when these are the enemies of their countries, are admired, but feared at the same time. [...] Napoleon or Alexander have not kept their position; but the heroes of the popular mind, the killers of dragons, are eternally beloved, whether it is the northern Siegfried, the Russian St. George, or the Arabic Ali. In some way they express the fight against darkness and fear, the hero who does not stand in the historical arena for personal success but for the peace of his fellow-men's minds and their moral security. (Memoirs 118) 
The excerpt outlines the difference between male conquerors who used their power to achieve personal success, and those whose main scope was protecting the common people. The first category includes figures of doubtless historicity, such as Napoleon, Alexander, and certainly Atatürk. The second, instead, comprises figures of religion and folklore. The assumption that the protagonists of folkloric legends live longer in the popular imagination than awe-inspiring historical figures appears arguable. Nevertheless, through this distinction, Edip lays emphasis on the desirability of a more flexible vision of history encompassing the factual and the fictional (Trinh 120).

The figure of Ali introduces a concept that features prominently in Shafak as well, namely, the coexistence, within Islam, of a stern, intimidating component and a more compassionate, accessible one.

From the material and the political point of view, Ali is the least successful Islamic hero. Every adversary of his takes advantage of his nobility of heart. In the Battle of Saffein his enemies, unable to conquer him in fair fight, put Korans on the ends of their spears and appeal to his veneration for the sacred word. Ayesha, the great woman warrior and orator, the widow of Mohammed, merciless when she wins, is forever taking advantage of his chivalrous respect for women and of his admiration of the Prophet. He finally dies unsuccessful but undaunted, always morally clean, manly and humane to his enemies, tender and good to the weak. (Memoirs 118)

The passage displays a clash between two tendencies Edip locates within Islam: the more humane approach, represented by Ali's "nobility of heart" (ibid.) and chivalry, is regularly crushed by the dominant tendency, embodied by another prominent Muslim figure, Ayesha, here a "merciless" warrior. The emergence of a "religion of love" - "contemplative, pacific, feminine," to recall Köksal's phrasing (87) - side by side with a "religion of fear" (Shafak, "Religion of Love" n.p.) within the heterogeneous field of Koranic interpretation is a salient topic and will be returned to later. For the time being it suffices to say that, from a 'patriarchal' perspective (represented, remarkably enough, by Ayesha), Ali is "the least successful Islamic hero" (118). At the same time, the narrator reminds the reader that "there are so many religious sects [sic] that worship [Ali], not only as a great hero but even as the incarnation of Allah" (ibid.), and thus she clarifies that Ali's gentle heroism, too, enjoys significant favor among the Muslims. It is remarkable that, in this case, Edip does not mention Ayesha's central role in the battle against Ali's army, which went down into history as "The Battle of the Camel" (Basra, Iraq: 7 November 656). Due to her involvement in the struggle and her oratory skills, Ayesha is remembered as one of the first Muslim female leaders, but Edip chooses to focus on the figure of Ali, in all likelihood because of his affinities with the figure of Jesus Christ. By the same token, Edip prefers to award centrality to 
Emine rather than Ayesha, as the figure of the Prophet's mother can be easily juxtaposed to the mother of Christ, while Ayesha does not find immediate correspondents in the Christian traditions.

The figure of Ali in Edip's autobiography contributes to the familiarization of Islam for Christian audiences, and of her attempt, in Edward Said's word, to reduce Islam's hostility (87) and reconcile it with Christianity. The explicit comparison between Ali and Jesus makes an even stronger case in favor of this argument. “The Western mind's conception of Christ's achievement of success in the highest spiritual domain, obtained at the cost of suffering, shame, and a humiliating death," Edip writes, "has its counterpart in the mind of the Moslem in the personality of Ali" (Memoirs 119). The 'Western mind' and the 'Muslim mind' are therefore brought together by the figure of Ali and Jesus, highlighted as each other's "counterparts." Such correspondence serves the purpose of reminding Christian audiences that the ideals of Christianity are also to be found in Islam.

A reference to Mustafa Kemal completes Edip's discussion of myths of masculinity, establishing a parallel between religious and political narratives of dominant/deviant masculinity. Kemal's opinion of Ali is unsurprisingly disparaging. "I was interested to observe [Kemal's] contempt for what he considered Ali's weakness. 'Ali was a fool,' he used to say" (Memoirs 119). As the reference to Kemal demonstrates, historical and religious myths of masculinity in history and religion are interdependent and interconnected. The image of the lone conqueror, the prophet-like leader and father of a nation, informs Turkish historical as well as religious narratives, centered on male singular protagonists such as Kemal and Mohammed. Through the figure of Ali, Edip's text, once again, highlights the presence of a different message in the Koran, more fit to the needs of the 'subaltern' - women, children and the lower classes. For them, Ali is the ideal hero.

But I found my hero at last in Ali, the fourth caliph, the Lion of Allah and the son-in-law of the Prophet. The stories of Ali were also war-tales, but I never wondered about the fate of children and the simple crowd under his sway. On the contrary I felt confident that they had a greater peace of mind and felt safer simply because Ali lived among them. (Memoirs 119)

Once again, Edip's portrayal of Ali has two functions: first, it challenges maledominated historiography and religion through figures who transcend canons of masculinity, second, it is part of a process of familiarization of Islam for Edip's American and Western readerships. Islamic doctrine in Edip's autobiography is, as Said would put it, "presented in a form that would convince Christians" (60) 
through the emphasis on parallels between the "Western and the Moslem" minds (Memoirs 119). This way, Islam is "transubstantiated from resistant hostility into [...] partnership” (Said 92). Moreover, Edip's insistence on a more compassionate, benevolent, and democratic version of Islam contributes to dispel what the West was inclined to consider the "threat of Islam" (ibid.).

\section{A Religion of Love and a Religion of Fear: Mitigating the East/West Divide in the Aftermath of 9/11}

Edip's memoirs highlighted two different readings of Islam: one stressing features that could appeal to what she perceives as a Christian ethos, such as love, universal salvation, compassion for the lowly, and openness towards women, and another, less approachable, distant from the strivings of individuals and dominated by male figures. ${ }^{73}$ Eighty years after the publication of Edip's memoirs, a similarly dichotomous understanding of Islam resurfaces in Shafak's fictional and non-fictional writing. The following section illustrates how Shafak's journalistic articles and The Bastard of Istanbul configure these two doctrinal dimensions. The texts that constitute the focus of this section show how Shafak used the dichotomy between a religion of love and a religion of fear in the same way Edip did, namely, to renegotiate the position of women within Islam and, correspondingly, to highlight affinities with Christian sensitivity in an American perspective.

In a 2003 interview, Shafak highlighted a dualism between two distinct interpretations of Islam she had experienced in her youth, Jamal and Jalal. Each of these was introduced to the writer by one of her grandmothers:

In Turkey, in early childhood, there was a time when I found myself moving between two cities, two grandmothers, each in utterly different worlds. The grandmother on my father's side in Izmir was quick to teach me "fear." Her Jalal (punishing and masculine) God was an ever-watching eye, always watching you and seeing every single move you made down here. Returning from that house I was full of fear and the thrill of the thought of being watched constantly was inscribed in every move I made. (Shafak, "Migrations" 56)

The same considerations appear in a different article, entitled "Women Writers, Islam, and the Ghost of Zulaikha" and published on Words without Borders in 2005.

73 This binary approach to Islam, featuring prominently in both Shafak and Edip, seems to contradict their shared concern with building connections and promoting reconciliation. 
The Jalal side of Allah appealed to [my paternal grandmother] more than anything else. She taught me about the patronizing, paternal, and celestial gaze always watching me from above to then make a note of all the sins I committed down here. I came back from her house slightly traumatized, unable to go to the bathroom for fear of being seen naked by Allah, ashamed of the body given to me. ("Women Writers" n.p.)

It is the paternal grandmother who makes the writer acquainted with the Jalal god, "punishing and masculine" (ibid.), and with a religion of fear. This might be a further attempt to connect the Jalal side of Islam with patriarchy and orthodoxy, and connote it as essentially masculine in spite of its female practitioner: the narrator's grandmother. This approach limits the narrator's personal freedom, as she imagines to be constantly kept under surveillance. The second excerpt addresses issues of gender more explicitly, blaming the Jalal tradition for inducing women to be ashamed of their body.

Shafak's maternal grandmother embodies the antipodal approach:

my grandmother on my mother's side introduced me to a very different idea of God - a Jamal (beautiful and feminine) God - one that was based on love and with whom you could always negotiate. Her understanding of religion was more fluid, like water, and it was also full of superstitions. A tradition of faith that sees human beings in the image of God and venerates the individual in his/her totality. In time, I came to realize the tension between those who prioritize Jamal and those who prioritize Jalal as aspects of God, that these might have serious implications in daily life, especially for women. ("Migrations" 56)

In contrast to the Jalal god, the maternal grandmother's Jamal god is a "feminine" entity (ibid.), and the passage suggests that the position of women in society very much depends on which of the two interpretations is followed. Should the Jalal interpretation prevail, women would be confined to the margins; should the Jamal be prioritized instead, women would be awarded centrality and relevance. Another considerable difference is the regard for the individual. The Jamal tradition has a strong 'humanistic' vocation, implying that man can "negotiate" (ibid.) with God on equal terms. The term "venerate" (ibid.) is tellingly used in reference to "the individual in his/her totality," instead of the deity. Therefore, Shafak's notion of Jamal God mitigates two aspects of Islam that the West may find most perplexing: the condition of women and the claims Islam allegedly lays on individual freedom.

Let me reiterate that Edip's effort to reconcile Islam and Christianity in her writing is grounded in her early formative years at an American missionary school, causing her to develop a broader, more fluid idea of religion that may be compatible with both her Muslim background and the memory of her American teachers. It is plausible that $9 / 11$ and its consequences sparked Shafak's similar 
interest in serving as a mediator of Islam in the West and the United States in particular. Shafak's 2006 article "The Religion of Love" expresses the urgency to distinguish Islam from the misrepresentations that flooded the media after 9/11 and contrast the rise of Islamophobia in the West. The article expands on the difference between a religion of love and a religion of fear within Islam, the latter being a result of the politics of fear in the aftermath of $9 / 11$ :

we live in an increasingly polarized world in which the number of people who believe in a "clash of civilizations" between Islam and the West is escalating by the day. Hard-liners in one country produce even more hard-liners elsewhere. Amid this troubled framework, one fact that is frequently ignored is how heterogeneous, vibrant and dynamic the Islamic world is. ("Religion of Love" n.p.)

The excerpt reflects on a growing fear of the Other in the "troubled framework" (ibid.) of post 9/11 society. Through these first lines, Shafak implies that a more detailed knowledge of doctrinal differences within Islam may abate the perceived conflict between "Islam and the West" (ibid.). Furthermore, Shafak presents herself as an advocate of the Islamic world as a heterogeneous reality. Shafak's 2010 novel The Forty Rules of Love can be read as another attempt to dilute the alleged threat Islam poses to an Islamophobic West. Yet, despite Shafak's plea to acknowledge the doctrinal complexities of Islam, Forty Rules severs Sufism from its doctrinal context and presents it as a malleable creed that can be effortlessly adapted to the American spirit. The impact of a specifically American understanding of Sufism on Forty Rules will be returned to in the following chapter.

"The Religion of Love" proceeds by reiterating the love/fear dualism within Islam, addressing it in terms that are reminiscent of the 2003 interview analyzed earlier:

There is a noteworthy difference between exoteric, orthodox, mainstream Islam and esoteric, mystical and the heterodox versions of Islam. The second path has always been more flexible, more individualistic and more open to women. It is sad that in today's contemporary world of politics, all these subtleties are lost and Islam is thought to be one big monolithic bloc. ("Religion of Love" n.p.)

Once again, heterodox Islam is presented as "flexible, individualistic, and more open to women," and the values of humanism, universalist spirituality, and femininity are emphasized throughout the second part of the article. If Edip professes that the position of non-Muslims was "the primary injustice of [her] religion," Shafak readily reassures non-Muslims by revisiting the infamous concept of $\mathrm{Ji}$ had, constructed by the media as a tangible threat to Western society.

Take the nowadays notorious notion of jihad, for instance. For the Sufi, jihad means only one thing: an inner journey for self-improvement and the battle against nefs [aspects 
of one's personality that privilege egotism] that come along. It has nothing to do with "collective war against infidels," it is not outer-oriented. If anything, it is internal and therefore private and individual. ("Religion of Love" n.p.)

Not only is the idea of Jihad emptied of violence and situated in a thoroughly metaphorical dimension, it is also an indication of the major role the individual plays in his/her own spiritual enhancement. Shafak reformulates the notion of a collective war into an individual journey: flexible, negotiable, and designed to fit each believer's needs.

If Edip uses the figure of Emine, Mohammed's mother, to reinforce women's voice and centrality, Shafak does so by rewriting the figure of Zulaikha, the Koranic queen who attempts to lure Joseph into adultery and, after he refuses, accuses him of having violated her. Zulaikha is a crucial figure in Shafak's writing, so much so that the author describes her work as "a tribute to Zulaikha" "Women Writers" n.p.). In the orthodox doctrine, Shafak explains in "Women Writers, Islam, and the Ghost of Zulaikha" (2005), Zulaikha figures as a thoroughly negative character, dominated by lust and hedonism. "For the Sufi," Shafak continues, "Zulaikha simply represented someone purely and madly in love" (ibid.). Shafak touches upon the dual interpretation of the figure of Zulaikha once again in a column for the Turkish newspaper Hurryiet:

for the Sufi, Zulaikha is the symbol of a person lost in love. Nothing more, nothing less. For the orthodox-minded, however, she is nothing but an immoral woman unable to control her desires and needs, and thereby corrupt and immoral. These two utterly different interpretations of Zulaikha in the Islamic narratives are representative of the existing variations in the history of Islamic thought. (“The Sufi Way" n.p.)

By defining her work as a tribute to Zulaikha, Shafak attempts to redefine the role of women, and women writers, within Islam. Shafak's celebration of the Koranic Zulaikha coalesces with her demand for space, visibility, and acceptance for women writers in Islamic contexts. Moreover, Shafak acknowledges the central role of Sufism in the rehabilitation of female voices within Islam.

Through the figure of Zulaikha, Shafak aims to reconcile Islam not only with a dimension of femininity, but also with love and sexuality. "For many Westerners," writes Shafak, the juxtaposition of the terms Islam and sexuality evoke gloomy pictures of "honor killings, virginity tests, polygamy, homophobia, and the erasure of the female body behind veils" (ibid.). She reminds the reader that "sex and sexuality in the Middle East is [sic] not only about customs and prohibitions, much less captivity and confinement, [but] also about delight and joy, physical pleasure, emotional gratification and spiritual euphoria" (ibid., emphasis added). Shafak suggests that both approaches - confinement and exaltation of femininity 
and sexuality - are intrinsic to Islam, but while the former pertains to orthodoxy, the latter is typical of heterodoxy and Sufi mysticism.

Shafak's domestication of Islam, although well-intended, suffers from a major drawback. Despite Shafak's frequent reminders that Islam must not be regarded as "one big monolithic block," her own division of Islam into two opposed currents is also highly dissatisfactory. In other words, although Shafak celebrates Islam as a "heterogeneous, vibrant and dynamic world," her actual representation of it is far from doing justice to "the nuances in the terrain of Islam" ("Religion of Love" n.p.), namely, the multiplicity of currents and traditions constituting the multifarious Muslim world. Shafak seems more inclined to divide Islam into two Manichean categories: on the one hand the orthodox, masculine, dictatorial religion of fear, on the other hand the humane, feminine, pacific Sufi tradition, the religion of love.

In conclusion, Edip's rewriting of religion is permeated with references to Christianity and aimed at American readerships. The same is true for Shafak's, which reassures Western readers that the representation of Islam provided by the media after September 11, 2001 is limited and biased. In the process of familiarizing Islam for Western readerships, Edip and Shafak abundantly stress the crucial role Sufism plays in the rehabilitation of feminine perspectives within Islam and in the establishment of cultural affinities between Turkey and America. The following chapter will expand the discourse on Sufism in Turkish American literature, giving prominence to its contribution to the construction of a shared Turkish American literary tradition. 



\title{
IV. Sufism in America and Turkey: A Transnational Dialogue
}

\author{
"What problem is there in finding God? \\ It only needs to be uprooted there and transplanted here."
}

Bulleh Shah

The previous section has begun to outline how the theme of Sufism ${ }^{74}$ allowed Turkish American authors to establish a compelling connection between the Islamic and the Christian traditions, laying emphasis on their compatibility. This chapter continues to investigate representations of Sufism as a transatlantic phenomenon and its potential as a salient 'contact zone' between Turkey and America. Previous chapters have demonstrated the uniqueness of Turkish American texts by comparing them to others that are more firmly (although not univocally) anchored in the Turkish literary scene, such as Pamuk's novels. The present chapter asks to what extent Turkish American literature subscribes to American narratives and approaches, and does so by comparing texts by Elif Shafak and Güneli Gün with the work of authors who are unarguably rooted in the American canon, such as Ralph Waldo Emerson, Walt Whitman, and John Barth. Sufism lends itself particularly well to this task because of its distinct presence in both the American and Turkish American imaginations.

"There are many similarities between the rise of Sufism in Islam [...] and Transcendentalism in the United States," British Iranian scholar Farhand Jahanpour argues in his article "Ralph Waldo Emerson and the Sufi: From Puritanism to Transcendentalism" (6). In "Emerson and the Sufis," George K. Rishmawi claims that Transcendentalists may have identified with the Sufi's spiritual enfranchisement from Islamic orthodoxy and may have found in the separatist impetus of

74 Sufism is a mystical, heterodox current of Islam. Jahanpour speaks of Sufism as a "general gospel of individualism and spiritual exultation" (6), emphasizing the focus of Sufism on the individual and his/her journey towards God. In order to symbolize the inebriating effect of the union with God on the individual's soul, in fact, Sufi poetry largely relies on a vocabulary of "spiritual exultation," such as erotic and drinking imagery. Introductory studies on Sufism include William Chittick's Sufism: A Short Introduction and The Sufi Doctrine of Rumi, Annemarie Schimmel's Mystical Dimensions of Islam and As Through a Veil: Mystical Poetry in Islam, Alexander Knysh's Islamic Mysticism: A Short History, and Seyyed Hossein Nasr's Sufi Essays. 
the early Sufi traces of their own. Rishmawi envisions Transcendentalism as "an American movement that has tried to rid itself of the strong sense of evil which dominated the Puritanism of New England, from which it has originated" and notes that Sufism itself had been born as a reaction to the limitations of orthodoxy and to the power of religious authorities (149).

Transcendentalists looked East and found in Sufism a "splendid deviation" from the rigidity of doctrine and social conservatisms (Rishmawi 153). Emerson and the Transcendentalists, Rishmawi adds, had cast Sufi poets like Hafiz and Saadi as free-thinking icons who had fought for and achieved intellectual independence, and indicated them as examples of self-reliant men (Rishmawi 153). Not only did the Transcendentalists strongly identify with the concerns of Sufism, but there is evidence that their knowledge of and fascination for Sufism assisted them in their effort to delineate a "uniquely American" literary sensitivity (Jahanpour 8). Thus ingrained in the texture of Americanness, it comes as no surprise that Sufism, or an American manifestation of it, traversed the epochs and re-surfaced in the $21^{\text {st }}$-century "Rumi phenomenon" (El-Zein 71).

For a writer of Turkish origins who seeks to establish a cultural kinship between America and Turkey, the confrontation with the Sufi tradition on both sides of the ocean is inevitable. Crucial tenets of Sufism such as the reaction against religious authority and the aspiration to a universal spirituality allow one to establish a triangulation among Sufism, America, and Turkey. The first part of this chapter will outline the influences of American romanticism on Shafak's 'Sufi novel' The Forty Rules of Love (2010). I will argue that Shafak's Sufi novel is also an 'American' Sufi novel, as it embeds one of the best known Sufi narratives ${ }^{75}$ - the encounter between Rumi and his spiritual companion Shams of Tabriz in an American context, merging a Muslim understanding of Sufism with an American one. The second part will address the resurfacing of the discourse on Sufism in postmodernism, focusing on the work of John Barth and Güneli Gün.

\section{The American Journey as Sufi Journey: Emerson and Shafak}

Several scholars investigated major American Transcendentalists such as Emerson, Whitman, and Thoreau in the light of their interest in 'Eastern' poetry. Rishmawi reports that Emerson was "influenced by Eastern culture" and "involv[ed]

75 The life of $13^{\text {th }}$-century Persian poet Jalal Al-Din Rumi (Balkh 1207-Konya 1273) has been accurately documented, but some of its aspects are still shrouded in legend. One of these is his extraordinary friendship with Shams of Tabriz, a wondering dervish who crossed paths with Rumi in Konya when Rumi was 39 years old. 
with the poetry of the Sufis," which he read extensively in Joseph von Hammer Purgstall's German translation $(147,149)$. According to Arthur Ford, Walt Whitman owned a copy of William R. Alger's The Poetry of the East, whose introduction he read over and over (12). He had also certainly read Emerson's essay "Persian Poetry" (ibid.). Thoreau himself showed remarkable knowledge of Sufi poetry: Walden is interspersed with quotations from Saadis Gulistan (Farzan 573) and Farid al-Din Attar's The Conference of the Birds. Thoreau's warning "We do not ride the railroad; it rides upon us" (Walden 75) is probably a re-adaptation of Attar's verse "And I am not my Self's ass, he is mine; [ [...] the beast I ride on rides on you" (Attar 63).

Jahanpour draws a compelling parallel between Emerson's personal development, the trajectory followed by Transcendentalism, and the Sufi experience.

The study of [Emerson's] religious thought charts the journey from a narrow and dogmatic religious outlook towards a mystical, universal outlook. The study of Emerson's journey from Puritanism, towards Unitarianism, towards Transcendentalism and ultimately towards a universal religion of love and spirituality provides a powerful antidote to the narrow and fundamentalist interpretations of religion prevalent in both the East and the West today. (1)

This passage offers a first stepping stone to identify the Sufi "journey" as a recurring trope, a narrative from the East that has successfully been integrated into American paradigms of thought. More specifically, the Sufi journey (to appropriate Jahanpour's metaphor) translates into the Transcendentalists' ambition to resist fundamentalism and develop towards more inclusive models of religion and society. This is exemplified by Emerson's own writing, which moves away from the legacy of Puritanism towards a more universal, welcoming religious thinking that may better satisfy the needs of an ever more variegated society.

The trope of the Sufi journey, with its invitation to figuratively destroy temples, mosques and other symbols of the established religious authority, can be applied to the Transcendentalists' rejection of Puritan orthodoxy, as well as to their emancipation from the European intellectual tradition, as Jahanpour defines Emerson's religious reformism as part of his attempt to "create a uniquely American body of literature, molding a national identity out of its European roots" (8-9). Sufi poet Bulleh Shah (1680-1757) wrote:

Destroy the mosque!

Destroy the temple!

Destroy whatever you please. 
Do not break the human heart,

For God dwells therein. ${ }^{76}$

(Bulleh Shah in Jamal n.p.)

Emerson echoes this recurring principle, which resurfaces in several works of early Sufi poets: "How little love is at the bottom of these religious shows; congregations and temples and sermons, - how much sham!" Emerson laments in his journals (Emerson in Jahanpour 3). For Emerson, tradition is an impediment keeping man and God apart, and hindering the individual's perception of God's absolute truth: "When we have broken our god of tradition and ceased from our god of rhetoric, then may God fire the heart with his presence" ("The Oversoul" n.p.). As many have argued up to this point, Emerson's hard judgment on traditional religious institutions - the congregation, the church, the sermon - as misleading idols that must be renounced is reminiscent of the Sufi's mistrust of orthodoxy. The consequences of such disavowal - the image of God setting fire to the heart of men - also resonates with Sufi poetics, which frequently linger on love, fire, and the human heart as God's privileged dwelling.

The reported passage by Jahanpour has highlighted another aspect of America's Sufi journey, namely, its continuous resurfacing throughout American literary history. "The study of Emerson's journey," and therefore of the Transcendentalist and American journey, "towards a universal religion of love and spirituality provides a powerful antidote to the narrow and fundamentalist interpretations of religion prevalent in both the East and the West today" (Jahanpour 1). Jahanpour claims that a Sufi-like "journey" is a constituent of American national identity and must continue to operate throughout history, making it possible for certain cultural traits - diversity, inclusiveness, tolerance - to prevail over others. This is in fact Jahanpour's invitation to his contemporaries: to reflect on Emerson's Sufi journey and replicate it. If in the $19^{\text {th }}$ century Sufism inspired the literary fathers of a country that was struggling for self-definition and enfranchisement from the European and Puritan legacies, now that same ideology may function as an "antidote" to post 9/11 Islamophobia (ibid.). It is exactly in this scenario that The Forty Rules of Love can be collocated, considering its urge to treasure diversity, animate a cosmopolitan vision of society, and think of religion in terms of universal spirituality rather than dwell on its extremist manifestations.

76 These lines are also reminiscent of Whitman's words in "Song of Myself": "this head more than churches, bibles, and all the creeds" (Whitman 29). Here, the speaker invites the reader to forsake traditional forms of belief to venerate the human being in its complexity. Whitman's line is less mystical and more humanist, yet, the idea of the self as the dwelling of what is most sacred remains. 
It is not surprising that Sufi poetry has been increasingly constructed as antipodal to rampant post 9/11 Islamophobia. The Sufi's focus on love and tolerance offered a bewildering alternative to what had been depicted by the media worldwide as a religion of fanaticism and violence. For instance, historian William Dalrymple constructs Sufism as "a resistance movement against violent Islamic radicalism" and the most moderate, composite, and pluralistic of Islamic currents ("The Muslims in the Middle" n.p.). Dalrymple employs militaristic terminology to enlist Sufism as an ally of the West in the struggle against Islamic fanaticism ("Sufis, our allies within Islam," "Sufi imams are the front line against the most violent forms of Islam;" ibid.), but does not fail to stress the indigeneity of Sufism in an Eastern, Muslim context and describes it as "an indigenous, deeply-rooted resistance movement" (ibid.).

The most powerful incarnation of this Sufi revival in the United States is what Amira El-Zein calls the "Rumi phenomenon" (El-Zein 71), which allowed Rumi to become America's bestselling poet from the 1990s on, with sales unsurprisingly skyrocketing after $9 / 11$. The Rumi phenomenon can be read in combination with the $19^{\text {th }}$ century myth of the therapeutic Orient. Edward Said explains that Friedrich Schlegel and Novalis urged Europeans to dedicate themselves to the study of Eastern cultures, so as to "defeat the materialism and mechanism and republicanism of Occidental culture" (Orientalism 115). The Orient as source of healing for the West resurfaces in the Rumi phenomenon: Cyrus Masroori, for example, celebrates Rumi as cultural mediator: "at a time of suspicion and distrust, a person who can speak to both Muslims and the West is of great value" (243). On a similar note, in The Forty Rules of Love a character named Aziz writes: "In many ways the $21^{\text {th }}$ century is not that different from the $13^{\text {th }}$ century. Both will be recorded in history as times of unprecedented religious clashes, cultural misunderstandings, and a general sense of insecurity and fear of the other. At times like these, the need for love is greater than ever" (15). Aziz's statement is strongly reminiscent of Masroori's: the article and the novel were both written in the same year, 2010, and both of them present Rumi as the solution to the problems of Western society in times of alleged cultural clashes.

Traces of this argument can also be found in Jahanpour's article. In the early 2000s, when the Islamic Republic of Iran was perceived as a potential threat to Western ideals and geopolitical safety, Jahanpour lays emphasis on the commonalities between the American and the Iranian literary traditions: "At a time when political relations between Iran and the United States are so tense and the two nations are viewing each other with hostility and suspicion, it is important to remember that the cultural and literary relations between them have not always 
been so acrimonious" (Jahanpour 1). This is how Jahanpour introduces his study on Sufi influences on Emerson. He reminds Americans of their special cultural bond with Iran - Rumi's homeland - using Sufism to construct an exclusive bicultural relationship between the two cultures. "However," Jahanpour continues, "it is important to know that the rich heritage of religious thinking in the United States itself contains the lofty idea that we can lift religion from its present sorry state and restore it to the more spiritual and universal status that is its true calling" (ibid.). Jahanpour invites Americans to repeat the journey that convinced Emerson to relinquish 'fundamentalisms' and embrace an ever more universal, inclusive, tolerant understanding of religion. The origins of this American journey, Jahanpour argues, can be found in the Muslim world, as it shares basic "common values" with the United States: values that contribute to building a sense of transreligious, transatlantic "common humanity" (ibid.).

Forty Rules renews the invitation to repeat a Sufi journey any American of good will and sufficient sensitivity is eligible to pursue. In the novel, Rumi's journey from orthodoxy to Sufi mysticism is also the journey of an American woman, Ella, towards self-awareness. Although Ella's journey is not as intensely spiritual as Rumi's, she frees herself from the conditioning of society and opens up to the unexpected, the unknown, the Other. Similar to Jahanpour, Shafak places America in a bi-cultural perspective where its present and future are inextricably related to those of other cultural realities.

As anticipated, one of the most salient characteristics of the Sufi journey in its American manifestation is the aspiration to universal, all-encompassing spirituality. In his article "An Islamic Language of Toleration: Rumi’s Criticism of Religious Persecution," Masroori identifies religious multiplicity as a recurring theme in Rumi's poetic production. Masroori clarifies that, for Rumi, "multiplicity of religious understanding is not alarming": quite to the contrary, "the essence of all religions is the same" (Masroori 249). The real cause of conflict, for Rumi, is not religiosity, which unites all men, but the institution of religion, which "deforms our understanding of God" (ibid.). This position is close to the Transcendentalists' idea of a church of mankind, from which "no pious Hindu, or Buddhist, or Muslim could be excluded" (Jahanpour 5). Emerson embeds this distinction between religiosity and religion as institution as part of a larger discourse of equality: "I do not find that the age or country makes the least difference; no, nor the language the actors spoke, nor the religion which they professed, whether Arab in the desert, or Frenchman in the Academy. I see that sensible men and conscientious men all over the world were of one religion, - the religion of well-doing and daring" (Emerson, "The Preacher" n.p., emphasis added). This statement, quoted from Emerson's 
essay “The Preacher," clearly distinguishes between religion as a criterion that separates men, along with age, country, and language, and religion as a practice that unites them, as it enhances traits he considers to be universally shared.

The principles of Sufism used by American romanticism to devise a uniquely American understanding of religion reappear in Forty Rules as part of a different mission. If, for instance, Whitman adopts Sufi aesthetics of placelessness and denationalized belonging and applies them to a markedly American sensitivity, Shafak moves away from the nationalist perspective that had characterized the American discourse on Sufism and enlarges its scope so as to include a global society and its need for a more multicultural, cosmopolitan model of civilization. Shafak's discourse on Sufism does not limit itself to delineating or confirming a country's national identity, but articulates a post-national utopia. Shafak's cosmopolitan model, inspired by the Sufi doctrine, is primarily designed to connect Turkey and the United States in the same way Jahanpour connected Iran and the United States. Acceptance of ethnic and religious multiplicity appears in Forty Rules as an answer to questions regarding both countries' identities in the global age. In this chapter I will differentiate the Transcendentalists' and the Romantics' use of Sufism to construct an American national literature from Shafak's prominently transnational perspective. Moreover, I will draw further connections between Shafak and another 'Father' of American thought whose work was profoundly influenced by Sufi poetry: Walt Whitman.

\section{Two directions in the American Discourse on Sufism: Whitman and Shafak}

Like Emerson, Whitman also cultivated an interest in Sufi poetry (Ford 12): according to Arthur Ford, Whitman's fascination for Sufism began during the early phases of Leaves of Grass, sparked by works such as The Poetry of the East, by W. R. Alger (1856) and certainly Emerson's essay "Persian Poetry" (1858). The triangulation of Sufism, Whitman, and Shafak is particularly evident and worth investigating in depth. Both Whitman and Shafak draw abundantly from Sufi imagery and themes, but they eventually distance themselves from Sufism and pursue their own literary agendas. My analysis shows that while Whitman merges the message of Sufism with a strong emphasis on the (albeit heterogeneous) nation, Shafak advocates a decidedly transnational perspective. However, while Whitman's poems reflect qualities of Sufi authorship, at least to a certain extent, the American subplot of Forty Rules deviates from the notion of Self that is proper to Sufism. The notion of Sufi authorship, which will receive more attention below, reveals productive intersections between American romanticism 
and Shafak's fiction. Whitman's and Shafak's appropriation of some of the literary strategies of Sufi poetry eventually culminates in a detachment from the original aesthetics of Sufism, which lays emphasis on the effacement of individual authorship and belonging, and results in the articulation of different ideas about nation and Self.

\section{The Transcendental Author: from National to Transnational Literature}

In Michael Frishkopf's definition, Sufi poetry is highly intertextual, and, by the same token, the Sufi author is a "generalized author," one who refuses the absolute paternity of his poetic production, and rather views it as the outcome of a "strongly connected spiritual-social network" (Frishkopf 92). This approach to authorship, Frishkopf argues, entails a marginalization of the individual author, perceived as subordinate to a textual and social community who contribute to the generation of a text. Frishkopf coalesces the author with the poetic persona, as in Sufi poetry the author's first name is also used to indicate the speaker in the poem, thus enhancing the feeling of a first-person, autobiographic involvement. It seems preposterous that the aesthetics of Sufism, which implied the "backgrounding of the individualized author and text" (Frishkopf 79) may have appealed to a poet like Whitman, whose poetic personae declare to be "solid and sound, [...] deathless and august" (Whitman 33). A philosophy that invites its adepts to pursue the annihilation of the Self in God and thus hopes to achieve "death before dying" (Elias 3 ) seems antipodal to an author figure who aspires "to cease not till death," and beyond (Whitman 20). Yet, paradoxical as it may seem, the speaker of Leaves of Grass does reflect what Frishkopf calls a generalized author, incorporating a larger social system into the nature and extent of his poetic inspiration, operating within a spiritually connected social network.

In "Song of Myself," the speaker is both exalted and dispersed. Although the 'author' is glorified as an emanation of God: "divine [...] inside and out, making holy whatever [he touches or is] touch'd from," he is not Roland Barthes' "authorGod," the bearer of final teleological meanings (Barthes 4). Whitman's authornarrator is a permeable entity, which opens up to as many readings as there are readers: "You shall not look thorough my eyes either, not take things from me/ You shall listen to all sides and filter them from your self" (Whitman 21). With these words, the poet-figure in Whitman's text abdicates his role as a bearer of teleological truths. Whitman's speaker shows the attributes of Frishkopf's "interauthor" (Frishkopf 92) and recognizes that his text is the result of a social network of textual producers and not the emanation of an autonomous intellect: 
These are really the thoughts of all men in all ages and lands

They are not original with me,

If they are not yours as much as mine they are nothing, or next to nothing.

(Whitman 31)

The speaker is conscious that his inspiration has not been granted to him exclusively, and aware of a spiritual-social network surrounding him:

And I know that the hand of God is a promise of my own,

And I know that the spirit of God is the brother of my own,

And that all the men ever born are also my brothers, and the women my sisters

and lovers,

And that a kelson of the creation is love. (Whitman 32)

The divinity of poetic inspiration does not lead to a glorification of the poet over his fellow citizens, but to a detection of the divine in each element of creation, which implies the sharing of merits and responsibilities of the poetic word.

Up to this point the poetic persona of "Song of Myself" matches the parameters of Sufi authorship as expressed by Frishkopf, including the possibility to connect with the human community in spite of differences in time and space. "Central to the Sufi reality is the alam," Frishkopf writes, "within which one may establish personal, affective relationships with other spirits, irrespective of distances in time and space" (Frishkopf 86). The notion of alam is very prominent in Shafak's Forty Rules, whose American subplot thoroughly revolves around the overpowering love relationship between Ella and Aziz, who have never met in the flesh, live continents away, and are eventually separated by Aziz's untimely death. This is one of the numerous correspondences the notion of alam finds in Forty Rules. The aspiration to develop a mode of communication that may encompass diverse realities and places is of paramount importance to Whitman as well. Arthur Ford points out that in "Salut au Monde!" Whitman lists a series of images of faraway places, and specifies that the same variety is contained within himself, so as to stress the inclusiveness of his vision and universality of his message (Ford 14). "What widens with you Walt Whitman?" asks the speaker, "Within me latitude widens, longitude lengthens" (Whitman 93).

It is true that, as Ghulam Fayez confirms, Whitman and Sufi poetry share a "dynamic, fluid, microcosmic and macrocosmic [Self], [who] can occupy infinite centers and overlap infinite centers at one time" (Fayez 18). Yet, the inclusiveness granted by a macrocosmic Self in "Song of Myself" mostly embraces a national experience. Even the Near East imagery in "Song of Myself," Ford clarifies, "suggest[s] the range and diversity of [Whitman's] own experiences and thus the experiences of the race" (Ford 16). The speaker of "Song of Myself" affirms to be 
"one of the Nation of many nations" and proceeds to list a series of American locations, declaring to feel at home in "the fleet of ice-boats, $[\ldots]$ / on the hills of Vermont or in the woods of Maine, or the/ Texan ranch" (Whitman 31). Whitman's poetic persona does embody the Sufi notion of alam, which endows him with a ubiquitous quality, but his universality is deeply anchored in the American reality, whose vast range of landscapes and cultural manifestations are synthesized in the speaker's vision. In "Song of Myself," Sufi concepts such as the alam and the vision of nature and humanity as a spiritually connected unity are employed to express an American national conscience and reinforce its cohesion. The larger social and textual community that appears and participates in "Song of Myself" is the American community, and the speaker introduces himself as the transversal voice of his nation. He remains, in Ford's words, loyal to his "passion to be that most American of poets" (Ford 12).

Shafak also grapples with the de-individualization of the author in The Forty Rules of Love, which introduces three figures of Sufi writers - Rumi, Shams of Tabriz, and the present-day wandering dervish Aziz Zahara. As anticipated, Shafak's use of Sufism converges with and diverges from Whitman's, revealing striking similarities and one significant difference: the integration of the Sufi doctrine in a transnational discourse, instead of a primarily American one. Nevertheless, one can confidently affirm that the canons of Sufi authorship provide a common ground to Whitman's poetry and Shafak's fiction. The speaker in "Song of Myself" shares several attributes with Shafak's Shams of Tabriz, a character modeled on Rumi's legendary companion. Since Rumi's awakening to mystic poetry happens towards the end of the novel ("Maulana is writing verses, they are beautiful" announces Rumi's wife Kerra on page 286), from this point onwards my analysis of Sufi authorship in Forty Rules will concentrate on the figures of Shams and Aziz.

First of all, the strongly connected spiritual network theorized by Frishkopf as the ideal dwelling of the Sufi author prominently reemerges in Forty Rules when Shams declares that "the universe is one being, everything and everyone is interconnected through an invisible web of stories. Whether we are aware of it or not, we are all in a silent conversation" (207). The "invisible web of stories" brings to mind the derivative quality of Sufi textual production, which does not envision itself as the product of an individualized author, but rather a distillate of preexisting textual and cultural knowledge, the paternity of which is promptly rejected by the author.

Despite the fact that Shams - whose verses have been overshadowed by $\mathrm{Ru}$ mi's more conspicuous production - is a model of authorial selflessness and humility, traces of the Author-God can be found in Forty Rules as well as in "Song of Myself," as in both texts the Sufi author is exalted and dispersed. In Forty Rules, author and God share a common creative activity and are so intensely connected 
to appear interchangeable. "God is the greater storyteller" (275) claims Shams, and Aziz is suspected to "have wanted to create his central character on his own image, just as God created human beings in his image" (185).

The most important difference between Whitman's and Shafak's 'American' adaptations of Sufism is the idea of placelessness and denationalized belonging. ${ }^{77}$ A prerequisite of the Sufi author in both texts is the universality of his message, synthesized in the concept of alam. The rootedness of the author in several places at once leads, in Whitman, to an omni-comprehensive rootedness in a newly shaped national spirit. In Shafak, instead, it implies a lack of roots, and a renegotiation of the concept of belonging. If Shafak follows Rumi in indicating the lack of place as a legitimate space of belonging and thus has her characters affirm they belong nowhere, Whitman's speaker discards the idea of belonging by claiming to belong everywhere. Both Whitman's and Shafak's understandings of diffused rootedness originate from one of Rumi's poems, which leaves visible traces in both "Song of Myself" and Forty Rules.

Rumi (Mathnawi)

For I do not recognize myself

I am neither Christian nor Jew nor Gabr nor

Muslim

I'm not of the East nor of the West nor of the land nor of the sea.

(Rumi in Farzan 579)

\section{Shafak (Forty Rules)}

Not Christian or Jew or Muslim, nor

Hindu, Buddhist, Sufi or zen.

Not any religion or cultural system. I am

not of the East, nor of the West...

My place is placeless, a trace of the

traceless.

Whitman (“Song of Myself”)

A Southerner soon as a Northerner [...]

Of every hue and caste am I, of every rank or religion,

A farmer, mechanic, artist, gentleman, sailor, quaker,

Prisoner, fancy-man, rowdy, lawyer, physician, priest.

77 For a discussion of 'placelessness' see Wilbur C. Rich, The Post-racial Society is Here: Recognition, Critics and the Nation-state. Rich describes placelessness as a "world of everything and everybody being at home everywhere" (Rich 7). See also William Knoke, Bold New World: The Essential Road Map to the Twenty-first Century (1996). 
Massud Farzan claims that the reported extract from "Song of Myself" has been inspired by Rumi's poem "Why think thus oh man of Piety," appearing in the first column (Farzan 597). Having stated his condition of rootlessness, the speaker's individuality fragments into a series of figures that might compose the variegated texture of any society were it not for the reference to Quakers, who locate the speaker's multifarious embodiments in a Western, Christian context. As the second column demonstrates, Forty Rules displays a similar fragmentation or dispersion of the Sufi author. The reported lines are uttered by Shafak's fictional Rumi, and they echo Sham's explanation of the wondering dervish condition: "In this state I roam east and west [...] having roots nowhere, I have everywhere to go" (39). While Whitman's poetic persona conducts his metaphysical roaming prominently within the American territory, Shafak's Sufi writers embrace a larger dimension. While Whitman's North and South correspond to the American North and South, as the speaker claims to be at home in Vermont as well as in Texas, Shafak's East and West delineate a global perspective.

In Forty Rules, the mission of the Sufi writer is to release a universal message that may speak to East and West simultaneously, in fact, Rumi is referred to as the "great scholar of East and West" (155)..$^{78}$ The discourse on the Sufi writer, whose mission is to spiritually unite heterogeneous or even conflicting cultures, is concomitant with a more general discourse on literature. Aziz is of the opinion that one of the strengths of good literature is "connecting people to distant lands and cultures" (Rules 13) and "sincerely believe[s] that [his novel] cuts across countries, cultures, and centuries" (14).

The ocean, besides being a prominent trope in the Sufi symbolic universe, assumes further relevance in Shafak, as her Sufi author is not simply concerned with producing universal literature, but attempts to engage two hemispheres in a transatlantic dialogue. In Sufi poetry, the ocean is often a symbol of self-dissolution in the vastness of the divine. My contention is that this image has acquired special relevance in the American discourse on Sufism, and in Shafak in particular, as the latter has devoted much of her written production to the constitution of a transatlantic dialogue between Turkey (not coincidentally the place where Rumi spent most of his life) and the United States.

In Forty Rules, the ocean appears as a space of reconciliation, where dualities cease to exist: "If you and I can play even a minute role in helping two rivers meet

78 In Forty Rules 'East' and 'West' are unevenly capitalized. In his translation of Rumi's Mathnawi, Jawid Mojaddedi used capital letters "when reference is made to God" (Mojaddedi xxvii). A similar criterion might be applied in Forty Rules, but this hypothesis is difficult to prove. 
and flow into the ocean of the Divine Love as one single watercourse, if we can help two good friends of God to meet, I will count myself blessed" (69). Even though, in this case, the "two rivers" bound to meet are Rumi and Shams, the image of the ocean easily transports the metaphor on a cultural and territorial level, as does the reference to "two friends of God," which could potentially apply to Turkey and the U.S. as two nations in which the religious dimension plays a fundamental role. The ocean between two continents loses its divisive quality to symbolize the synthesis and reconciliation of two continents. The ocean is also employed to support the concept of the threshold homeland, which is especially dear to Shafak. "The water that scares you rejuvenates me," Shams declares, defending his vocation to Sufism and to the life of wandering dervishes, "for unlike you I can swim. And swim I shall. The ocean is my homeland. If you are with me, come to the ocean" (Rules 39). Once more, the potentially terrifying nature of the ocean turns into an inviting vision of home, and a legitimate, although unconventional, space of belonging. This theme resurfaces in Shafak's journalistic articles, where she interrogates her reader on Turkey's ambivalent location in the geopolitical scene, wondering if it is possible "to take up one's abode in a threshold" ("Making Sense of Irrationality" n.p.). By defending his life choice, Shams grants legitimacy to the condition of living in-between worlds and nations, opening up to a post-national perspective. The image of the ocean, in conclusion, has a deep, multilayered significance in the novel. First, it indicates Sufism as a way towards the reconciliation between East and West on the grounds of what triggered their supposed 'clash': Islam. Second, it anticipates that, for all the American credentials of Shafak's approach, Sufism has a deep political and cultural relevance for Turkey as well.

Whitman's and Shafak's use of Sufi theories of authorship adds further evidence for the existence of an American literary discourse on Sufism: an undercurrent that emerged in the $19^{\text {th }}$ century and resurfaced in the 1990 s with what has been termed the "Rumi phenomenon" (El-Zein 71). This section has proposed that both Shafak and Whitman drew on the understanding of authorship in Sufi poetics, subscribing to different extents to its criteria. Like Shams and Aziz, the persona of "Song of Myself" is close to Frishkopf's definition of interauthor, aware of his partaking in a vaster textual system. Whitman's author voices the heterogeneous American multitudes and thus enables the rise of a national literature. The $19^{\text {th }}$ century witnessed the involvement of American intellectuals in the definition of a national literature and Self, unencumbered from mannerism and the legacy of the European canon. Both Emerson and Whitman worked towards the establishment of a genuinely American literary sensitivity and both of them resorted to Sufism to assist them along this path. In this light, Whitman's 
speaker emerges as an example of Frishkopf's inter-author, but also as Foucault's "transdiscursive author" (Focault 10), who witnesses the beginning of a national literary tradition. Transdiscursive authors, Foucault explains, "are unique in that they are not just the authors of their own works. They have produced something else: the possibilities and the rules for the formation of other texts" (ibid).

In a similar way, Shafak's Shams and Rumi appear as $13^{\text {th }}$-century pioneers of transnational literature. Forty Rules is a plea to follow their example and indulge in "good literature" that "cuts across countries, cultures and centuries" (Rules 13-14). It is remarkable that the aesthetics of Sufism, in Whitman, contribute to the ongoing delineation of a national literature. In Shafak's case, instead, they point towards the creation - or intensification - of a transnational, transatlantic, and post-national one.

\section{Sufi Selves in comparison}

The last section has touched upon the ways in which Whitman and Shafak incorporated Sufi doctrine and aesthetics in their work. One is certainly the notion of authorship, generating an incompatibility between the marginalization of the author in Sufi poetry, its complete de-individualization, and the overwhelming centrality awarded to author-figures in Whitman and Shafak. These two tendencies coexist in the speaker of "Song of Myself," who pronounces himself a divine messenger and voice of a nation, and in Shafak's Sufi authors Rumi and Shams. A similar duality emerges with regards to the Self. Frishkopf exhaustively describes the Sufi approach to the individual Self, and characterizes the Sufi way as a process that culminates in the "fana' al nafs (annihilation of the base ego), and baqa' (abiding in God). More modestly, the Sufi aims for some degree of self-dissolution" (Frishkopf 87). "Sufi ritual, social structure and doctrine," Frishkopf adds, "provide a strong formal basis [...] to undermine or replace the notion of an individualized self" (88). At first reading, it is striking that a doctrine whose final goal is the dissolution of the Self found its way into American romanticism and Whitman, famous for celebrating and singing the Self.

The following pages will shed light on the notion of the Self in Sufi poetry and its American and Turkish American manifestations. In order to do so, I will attempt further comparisons between Whitman's and Shafak's work and present their parallel negotiation of Sufi themes. Whitman's poems "Out of the Cradle Endlessly Rocking” and "As I Ebb'd with the Ocean of Life" - both part of a section of Leaves of Grass entitled "Sea-Drift" - will serve as an introduction to Sufi themes such as the disappearance of the Sufi author and the search 
for the Beloved in Forty Rules..$^{79}$ My argumentation tests the hypothesis that Whitman's legendary individualism does not amount to an open contradiction of the Sufi doctrine; on the contrary, the two lines of thought coexist side by side in Whitman's works. Shafak's 'Sufi novel,' instead, substantially deviates from the Sufi understanding of the Self in its American subplot.

"As I Ebb'd with the Ocean of Life" first appeared in 1860 under the title "Bardic symbols" in the Atlantic Monthly. It was subsequently integrated into the sixth edition of Leaves of Grass in 1881 (Oliver 36). Charles H. Morgan speaks of "As I Ebb'd" as a work that holds an extremely important place in Whitman's poetry as it represents one of the clearest expressions of an archetype of spiritual death and rebirth that, Morgan claims, traverses Leaves of Grass and constitutes a "structural principle" governing Whitman's poetry (Morgan 46, 41, 51). This poem is particularly relevant to my analysis due to the prominent role the ocean plays in it. Whitman makes frequent references to the ocean in his work (Oliver 37), but it has been previously established that the significance of the ocean increases when in concomitance with references to Sufi doctrine, both for Whitman and Shafak. The poem depicts a man melancholically walking on a beach, questioning his own ego, and ultimately contemplating suicide by drowning. Charles M. Oliver describes "As I Ebb'd" as a surprisingly pessimistic poem, considering the generally optimistic tone of Leaves of Grass. Oliver blames the dispirited tone of the poem on a tumultuous period in Whitman's life: “The author," Oliver explains, "shows his depression over what he sees as personal failure, perhaps the lack of public enthusiasm for his poems" (Oliver 37).

Oliver makes no mention of Sufism in his short entry on "As I Ebb'd" in Critical Companion to Walt Whitman (36-37), but Arthur Ford holds a different opinion. Ford states that the "central urge in every atom, [...] to return to its divine source" in "A Persian Lesson" - the text in Whitman's corpus that most explicitly references Sufism - echoes the yearning of the speaker in "As I Ebb'd" to "return to the Great Float or Mother of the Sea" (Ford 22). The ocean appears in fact in

79 I am aware that the two poems examined in this section do not figure among the texts that most distinctively demonstrate Whitman's fascination for Sufism. "A Persian Lesson" or "Song of Myself" would be more indicative in this respect, and for this reason they have been covered extensively in earlier scholarly work, such as Massud Farzan's "Whitman and Sufism: Towards a Persian Lesson." "A Persian Lesson," for instance, presents an explicit tribute to Sufism, as it describes an open-air lesson held by a "greybeard Suf” in a "teeming Persian rose-garden" and expresses Allah's ubiquity and the need of every particle to merge with the divine (Whitman 371). The first two poems of "Sea-Drift" also display Sufi themes and techniques, only in a subtler way. 
"As I Ebb'd" as a "fierce old mother endlessly cry[ing] for her castaways." The parallel highlighted by Ford is an incentive to attempt a Sufi analysis of "As I Ebb'd," as it would reconcile the glorious, overpowering idea of Self found elsewhere in Leaves of Grass with the Sufi search for annihilation in God.

Two different Selves can be detected in "As I Ebb'd": an oppressive "electric Self" antagonizing a "real me," holding it captive. The following quotation juxtaposes these two sides of the poetic persona.

I musing late in the autumn day, gazing off southward,

Held by this electric self out of the pride of which I utter poems

[...]

But that before all my arrogant poems the real Me stands yet untouch'd, untold, altogether unreach'd,

Withdrawn far, mocking me with mock-congratulatory signs and bows,

With peals of distant ironical laughter at every word I have written,

Pointing in silence to these songs, and then to the sand beneath.

(Whitman 174, emphasis added)

To put it with Frishkopf, the Sufi doctrine teaches that the "ego's self pride" stands as an impediment between the individual and his "true remembrance of origin as spirit" (100) and prevents the individual from "remembering the original Self" (86). This proves to be the case in "As I Ebb'd." Here, the speaker acknowledges the presence of an authorial Self, the poet, who oppresses him and holds him captive, and of another Self, "the real Me [...] untouch'd, untold, altogether unreach'd" (174). The latter Self is reminiscent of Frishkopf's "original Self," unspoiled by the egotistic pride of the first Self - the creative genius, the Author-God. Through the intervention of the original Self, the speaker is thus confronted with the irrelevance of his verses and the unjustified pride in having written them, as the original Self "point[s] in silence to these songs, and then to the sands beneath." Freed from the "electric Self," the speaker acknowledges his own insignificance and, humbled, compares himself to "sea rubbish" (Morgan 47): "I too but signify at the utmost a little wash'd up drift,/ A few sands and dead leaves to gather" (Whitman 174). It is not by mere coincidence that the speaker contemplates drowning himself - "merge [him]self as part of the sands and drift" (ibid.) - as, at that point, the Self would be reunited with its originative source, the ocean. Agreeably a bleak version of a Sufi awakening, "As I Ebb'd" nevertheless reflects the path towards self-annihilation in the divine indicated for Sufi adepts.

What surprises Whitman scholar Charles M. Oliver is the collocation of such a pessimistic poem next to "Out of the Cradle Endlessly Rocking," which he evaluates as "perhaps the most optimistic and upbeat poem in Leaves of Grass" (Oliver 37). Morgan, too, reflects on the strangely disheartening nature of some poems in Leaves of Grass. While several scholars read the poetry collection as an autobiography and 
attribute this phenomenon to a particularly traumatic period in Whitman's life, Morgan connects these "poems of despair" to the spiritual death and rebirth archetype (Morgan 41, 46). Seen from this perspective, which favors Whitman's mystical inclinations over the so called "crisis theory" (ibid.), the collocation of the two poems is not in the least surprising, since "Out of the Cradle" addresses a theme most dear to the Sufi: the search for the Beloved. For the Sufi, the Lover's longing and selfless search for the Beloved symbolizes the individual's search for God. Here, the speaker reports the affliction of a mockingbird who has lost his companion. "Loved! loved! loved! loved! loved!" (Whitman 172) cries the mockingbird, ceaselessly calling his lost companion. These words and the bird imagery compellingly call to mind Sufi atmospheres and symbolism. Considering that both "Out of the Cradle" and "As I Ebb'd" present Sufi themes, the proximity of these two poems in Leaves of Grass does not come across as surprising.

What is highly relevant for the goals of this section is that some passages of the mockingbird's song in "Out of the Cradle" are reminiscent of Shafak's Rumi, in particular of his anguish at Shams' disappearance. Both Shafak's Rumi and Whitman's mockingbird feel connected with their missing 'Beloved' across time and space, but both hesitantly wonder about the reliability of this perception. "You must know who I am, my love" (Whitman 171), the mockingbird says, while Shams, when still in search of his companion, wonders "will you recognize me when you see me?" (Rules 153). The Lovers in "Out of the Cradle" and Forty Rules seek their Beloved in nature, seeing them in a variety of natural phenomena even after their departure.

"Out of the Cradle"

That lagging, yellow, waning mood!

$\mathrm{O}$, under that moon, where she droops almost into the sea!

$[\ldots]$

O brown halo in the sky, near the moon, drooping upon the sea!

$\mathrm{O}$ troubled reflection in the sea!

$\mathrm{O}$ throat! O throbbing heart!

$[\ldots]$

In the air - in the woods - over fields;

Loved! loved! loved! loved! loved!
Forty Rules

You see him in the drop of water that falls into the ocean, in the high tide that follows the waxing of the moon, or in the morning wind that spreads its fresh smell; you see him in the geomancy symbols in the sand, in the tiny particles of rock glittering under the sun, [...] in your throbbing vein. 
In addition to the shared natural imagery that, in both cases, frames the search of the Beloved (the moon, the sea, the glittering of the rocks and waters), the common reference to throbbing hearts and veins is particularly poignant. It recalls in fact a passage from the Koran, reassuring believers that they are "closer to Him than His jugular vein" (Koran 50.16). This supports the hypothesis of a Sufi connection in "Out of the Cradle" and suggests that the Lover's quest for the Beloved is comparable to the quest for God. The disappearance of Shams' corpse into a well in Forty Rules, thrown by assassins who never hear the sound of the body hitting the water, the death of the mockingbird's companion in "Out of the Cradle," and the poet's suicidal fantasies in "As I Ebb'd" point to a degree of dissolution of the Self that characterized Sufi doctrine and has found its way into American literature. The Sufi message, requiring the annihilation of the Self or at least the most egotistic part of it, has to a certain degree been met by the American discourse on Sufism. Paradoxically enough, Shafak's carefully designed 'Sufi novel', especially in its American subplot, detaches itself the most from the Sufi way. The story of Ella, a Massachusetts housewife who revolutionizes her life after beginning an affair with the Sufi novelist Aziz, seems to subvert not only the Sufi notion of Self, but also the Sufi notion of love. The adaptation of Sufi doctrine in Forty Rules points at the book as a product of the American discourse on Sufism, rather than of the Muslim one.

\section{The Forty Rules of Love: A Secular Awakening}

In Forty Rules, the fictional Rumi follows a path of spiritual awakening that unfolds from the relinquishing of his former Self - that of a renowned, wealthy theologian - towards the development of mystical poetic inspiration and the creation of a new Self. The new Rumi, the Sufi poet, loses the social approval and spotless reputation he had enjoyed all his life, as many of his fellow citizens deem the message of his spiritual poetry - including erotic imagery, drinking metaphors, and dancing - to be an abhorrent deviation from Islamic orthodoxy. The protagonist of the American subplot in Forty Rules, the "unhappy housewife" Ella (10), is presented as a Rumi figure, replicating the same trajectory in an American context and in the $21^{\text {st }}$ century. Although Ella's 'awakening' is certainly an attempt to recast Sufism in American culture, it represents in fact the least spiritual of the Sufi trajectories examined in this chapter.

Ella is oppressed by a marriage that lost its vigor, by a man who confined her to a domesticity she found inspiring at first, but more and more dissatisfying with the passing of time. Like Rumi before his encounter with Shams, Ella is a role model for her community. Her husband's professional prestige reflects on 
her own reputation and her perfectly decorated house is the object of social approval. When Ella decides to accept a small job as book editor for a publishing house and is assigned the task to review Aziz Zahara's manuscript, she begins a journey towards a Sufi awakening. Yet, instead of the dissolution of the Self, Ella's goal is rather the reconstruction of a previously dissolved Self. Everything points towards Ella's lack of self-awareness as the cause of her domestic submission. Lacking will power and awareness of her capacities, Ella suffocated her vague, embryonic dream of becoming "a prominent book critic" (4) to marriage. After her encounter with Aziz's novel "Sweet Blasphemy," Ella starts to resent her choices and feels like "a cauldron whose lid ha[s] been lifted" (34).

To a certain extent, this process falls within the borders of the Sufi "pursuit of Self-knowledge" (Usher and Bano 5) and perception of the un-initiated as one who never entered his/her own heart (Usher and Bano 7). Usher and Bano argue that the Sufi pursuit of self-awareness has heavily influenced Emerson's work. Furthermore, Whitman's anguished discovery of an "untouch'd, untold, altogether unreach'd" real Self within a shell of authorial presumptuousness resembles Ella's "strangled self" (131). In the same way, the speaker of "As I Ebb'd" confesses that "amid all that blab whose echoes recoil upon me I/ have not once had the least idea who or what I am" (Whitman 174). As Ella's Sufi awakening progresses, and her self-awareness deepens, she discovers "a wiser, calmer, more sensible self" (Rules 173) and experiences the "withdrawal into a calm, private space of her own" which "strip[s] away the polite decorum behind which her marriage had slept undisturbed for many years" (176). This stage, paralleling Rumi's retreat from public life, is supposed to mark Ella's passage into a new stage of existence, which surprisingly entails no spiritual awakening. Her new Self is simply wiser, calmer and more sensible, and no reference is made to potential concerns for spirituality. On a practical level, Ella's passage into a new state of consciousness is marked by her fortieth birthday and by Aziz's peculiar birthday wishes.

Happy birthday! [...] did you know that in mystic thought forty symbolizes the ascent from one level to a higher one and spiritual awakening? [...] The flood of Noah lasted for forty days, and while the waters destroyed life, they also washed all impurity away and enabled human beings to make a new, fresh start. In Islamic mysticism there are forty degrees between man and God. [...] Jesus went into the wilderness for forty days and nights. Muhammad was forty years old when he received the call to become a prophet. Buddha meditated under a linden tree for forty days. Not to mention the forty rules of Shams. (115)

In the passage, Aziz provides an overview of the meaning of the number forty in different religions and the desire to bridge Islam and Christianity is obviously 
kept center-stage. Her "most auspicious" fortieth year (115) also convinces Ella's to finally defy social conventions and visit Aziz at his hotel in Boston.

At this point, the reader wonders if it is appropriate to define Ella's Sufi journey a spiritual awakening, as Ella's development appears to be a fully secular one. If one considers Rumi's and Ella's paths as parallel, Aziz's death would correspond to the disappearance of Shams, followed by Rumi's excruciating, definitive spiritual awakening to poetry and mysticism. Nevertheless, this spiritual climax finds no correspondence in the American subplot. Ella's objectives after Aziz's death are in fact rather mundane: "What was she going to do now?" Ella wonders, finally alone in Konya, "she didn't have any money, and she didn't have a job. But she could always give private lessons in English, work for a magazine, or who knows, be a good fiction editor one day" (349). "I am going to Amsterdam," Ella resolves, after some thinking, "they have incredibly cute little flats there, overlooking the canals. I can rent one of those. I'll need to improve my biking, I don't know..." (ibid.). ${ }^{80}$ The markedly un-spiritual ending of Ella's spiritual journey calls for a reconsideration of the religious significance of Sufism in American culture. A manifestation of American Sufism devoid of religiosity creates a cleavage between Shafak's use of Sufism and the Transcendentalists' or the Romantics', as in those earlier texts Sufi spirituality effortlessly flowed into Christianity. Shafak's Forty Rules portrays an America that appears significantly less concerned with religion than the Transcendentalists'.

Ella's dislike of religion - or "aversion" as she herself calls it (145) - provides more evidence of the secularization of Sufism in Forty Rules.

\begin{abstract}
I know you're a religious person, but I'm not. Though as a family we celebrate the Sabbath every so often, personally I don't even remember the last time I prayed. [...] There was a time back in college when I got hooked on Eastern spirituality and did some reading on Buddhism and Taoism. I had even made plans with an eccentric girlfriend to spend a month in an ashram in India, but that phase of my life didn't last long. As inviting the mystic teachings were, I thought they were too compliant and inapplicable to modern life. Since then I haven't changed my mind. (ibid.)
\end{abstract}

Ella's sullen, demotivated perspective represents religiosity as a mechanical family tradition, passively performed, a short-lived enthusiasm over a trend dismissed as part of the excesses of youth, or a bizarre bonding opportunity with

80 As a matter of fact, Ella's awakening is neither a spiritual awakening, nor a path towards gender awareness or emancipation. She is offered a small job thanks to her husband's contacts and even that does not result in any substantial empowerment: it merely enables the encounter with Aziz (her first customer), providing her with the opportunity to pass from the influence of one male lover to that of another. 
a long-forgotten "eccentric girlfriend." As the previous paragraphs have demonstrated, the Sufi itinerary followed by Ella does not involve a significant deviation from this early statement. It is nevertheless remarkable how the novel is aware of America's on-and-off infatuations with forms of "Eastern spirituality" (ibid.), and yet does not acknowledge that this might be the case with Sufism as well, especially if uprooted from its doctrinal specificity.

\section{Of Material Love and Ornamental Sufism}

The title The Forty Rules of Love anticipates the novel's strong emphasis on love. In fact, Ella's awakening can be confidently defined as an awakening to romance, rather than to Sufi spirituality. Romantic love is another element that exposes Ella's trajectory as a secular one as well as Shafak's definitive departure from Sufi doctrine. The Sufi's unbridled, inebriating exaltation of love as mystic longing for God or for a spiritual companion had a strong impact on Transcendentalism. To put it with Rishmawi, the "main force which drove some of these writers towards the East was [...] the desire to free themselves from the confines of their exacting religious background, which looked at sex or sexual intercourse as sins to be avoided, or suppressed" (Rishmawi 148-149). Emerson was nevertheless cautious in his approach to the sensuality of Sufi poetry, distancing himself from the "erotic and bacchanalian tone" of certain texts (Rishmawi 145). Finally, Whitman's reference to love as the "kelson of the creation" in "Song of Myself" (23) is reminiscent of the Sufi notion of love as the element creating cohesion in a universe pervaded by ardent pantheism, where all creatures are made equal by the act of loving God or each other.

In Forty Rules, love is stripped of most of its mystical resonance to embrace an erotic and materialistic dimension. Ella concludes the novel by saying: "Don't ask yourself what kind of love you should seek, spiritual or material, divine or mundane, Eastern or Western [...]. Love has no labels, no definitions. It is what it is, pure and simple" (Shafak 350). As the novel nears its end, it opens up to undifferentiated kinds of love as equally valuable paths to awakening or self-awareness. Nevertheless, the reference to "material" love as equal to "spiritual" love is highly ambivalent and not necessarily a statement the Sufi would have subscribed to. Ella's understanding of Sufism appears in fact closer to a 'whatever works' approach that mystifies the nature of Sufism as an outgrowth of the Islamic doctrine and nevertheless the very "heart" of that religion (Rishmawi 150). When Aziz presents Ella with "a necklace of turquoise and red coral balls with a silver whirling dervish" (Rules 303), the reader receives the inevitable confirmation that Shafak's Sufism may be mostly decorative and ornamental but much less spiritual. 
The previous pages amply discussed the Sufi imperative of relinquishing the Self in order to successfully attain the union with God. In Forty Rules, the extramarital relationship between Aziz and Ella is far from symbolizing the Self's passionate desire to dissolve in the divine. At least for Ella, the relationship with Aziz is tantamount to the carnal possession of a heterosexual object of desire:

Aziz reached around and pulled the pin holding her bun, letting her hair loose. Then he gently moved her onto the bed [...]. While his hands caressed every inch of her body, his eyes remained firmly closed and his lips prayed for her. It was the most spiritual thing she had ever experienced. And although she kept her clothes on, and so did he, and although there was nothing carnal about it, it was the sexiest feeling she had ever experienced. [...] With that feeling she put her arms around Aziz, ready to go further. (303-304)

The non-carnal nature of their intimacy is short-lived. The Sufi notion of mystical and selfless love swiftly transforms into an egotistical desire to possess the lover. In that same way, the entire work, presenting itself as a 'Sufi novel, gives in to romance. It comes as no surprise that, among the keywords on Forty Rules' copyright page, "Housewives - fiction" appears first, and "Sufis - fiction" follows in the third position. The novel fails to convey a convincing portrait of Sufism as it embodies the dangers and pitfalls of cultural translation. ${ }^{81}$ Nevertheless, the novel still represents a valuable attempt to build a transatlantic dialogue between the American and the Turkish traditions along the lines of Sufism.

\section{The Road to Baghdad Leads Somewhere: the (Ir)relevance of Sufism in Güneli Gün's On The Road to Baghdad}

The previous section has shown that Sufism holds an important place in American literary history and thus provides authors of Turkish American literature with an important resource to establish an intercultural dialogue between America and Turkey. My concern in the following pages is with the work of Güneli Gün, a Turkish American author based in Ohio, and her 1994 novel On the Road to Baghdad. This 'Sufi' novel simultaneously positions itself in the traditions of Sufism and postmodernism, as Gün was a student of John Barth's and her work was significantly influenced by her acquaintance with this American postmodernist author. Yet, Gün reinterprets American postmodernism by infusing it with elements from her own Turkish cultural background, drawing inspiration from Ottoman folklore and spirituality. One can confidently affirm that On the Road

81 See also Furlanetto, “The 'Rumi Phenomenon,” 208. 
to Baghdad is a unique, remarkable novel which effectively synthesizes the postmodern tradition, in its North American manifestation, with the Ottoman one.

On the Road to Baghdad narrates the adventurous journey of an Ottoman girl, Hürü, across the territories of the empire. The girl is abandoned by her brother as the family travels to Baghdad, an event that will mark the beginning of her long journey to be reunited with her parents. During this journey, Hürü embarks on a series of adventures that will involve, among other things, her training as a Suf, her marriage to a Sultan, her marriage to a woman, and a tormented friendship with legendary writer Shahrazad. Rich with supernatural beings and circumstances, fabulistic digressions, time travels, and embedded narratives, the novel is an unusual fairytale drawing from the Ottoman storytelling tradition as well as from postmodern narration techniques. I am convinced that the novel offers one more example of how Sufism may represent a surface where the Turkish/ Ottoman and American cultures can be successfully reconciled, even, and perhaps especially, within the iconoclastic severity of postmodernism.

Kader Konuk and Gönül Pultar question the relevance of Sufi symbolism in On the Road to Baghdad with regard to both its pertinence to the novel and its transnational potential. Konuk describes Gün's text as "situated between two irreconcilable positions: postmodernism's call to demystify the 'I' and the task of salvaging her own cultural heritage in the postmodern world" (Konuk, "Sufism and Postmodernism" 99, emphasis added). Konuk posits the adherence to postmodernism and the retrieval of the Ottoman cultural heritage as mutually exclusive categories, superficially and deceptively brought together by the image of the Sufi journey towards self-effacement. Konuk, who sees a correspondence between the fictional Sufi journey in the novel and the search for a "spiritual homeland," argues that "the dissolution of the self into the other is the task not only of the Sufi, but a demand [Gün] imposes on herself - an author of nonwestern origins who sees herself as a transmitter and conveyor of her own literary language" (100). Here, Konuk implies that the demand Gün imposes on herself would be her own dissolution, as a non-Western author, in the otherness of American literature. Pultar, although more positive about the novel's transnational appeal, is extremely critical when it comes to assessing the role of Sufism in On the Road to Baghdad. According to Pultar, the novel's confidence in Sufism as a source of personal salvation "cannot be taken seriously," as it remains "a mere anachronism and part of the absurdist paraphernalia of the novel." "The road to Baghdad," Pultar concludes, "leads nowhere" ("Travelling Biculturalism” 59).

The reason for Pultar's disenchantment with the novel's Sufi digressions is the very framework of the novel, which she defines "fantastic" and therefore liable 
of divesting Sufism of any "gravitas" (ibid.). What further deprives the novel of spiritual authority in the eyes of Pultar is the present status of Sufism in Turkey, which is reduced to a "mere tourist attraction [...] emptied today of any significance $[. .$.$] by obliging whirling dervishes" (ibid.). Thus, both scholars discour-$ age the reader from taking Sufi symbolism in the novel too seriously. The Sufi way may in fact offer no convincing path to salvation, as the book enigmatically ends with the disappearance of the two female protagonists, Hürü and the legendary Shahrazad, in a flash of blue and green light nearby the sacred city of Konya. Nevertheless, I propose that the significance of Sufism in Baghdad and the central role it plays in locating the novel in a Turkish American frame can be revisited. Baghdad is representative of Turkish American literature as it triggers a successful cultural dialogue between the Turkish and the American spheres, and does so by resorting, once again, to Sufism as a salient cultural component of Ottoman Turkey.

In her article "Güneli Gün on the Road to Baghdad: Travelling Biculturalism," Pultar makes a strong case in favor of the novel's capacity to integrate the American and Turkish cultures. She sheds light on the various elements that connect the Eastern matter of the book to the American literary tradition. Starting with the reference in the title, she claims that "the novel is in the vein of Jack Kerouak's On the Road and many others that have followed suit" (58). The journey Hürü embarks on can also be read in an American framework as a search for freedom, to be found at the end of the Road. The search for freedom of "an American woman," Pultar specifies, is "too adverse to an Ottoman weltanschauung" and more suitable to $20^{\text {th }}$ century America (59). Ultimately, Pultar connects Hürü's repeated attempts to 'pass' as a boy (52) to the issue of 'passing, an important feature of American culture.

Pultar also underlines the transnational character of the novel, adding that "an understanding of the two cultures involved is necessary for a satisfactory appreciation of the work," as the novel at hand is "neither Turkish, nor American, yet both" (49). The novel is a platform where both cultures function as "sites traversed," in so far as they are equally transgressed and othered, but their interaction excludes the hegemony of one over the other as they undergo a process of reciprocal adjustment (ibid.). The aim of this chapter so far has been to demonstrate that Turkish American writers have used Sufism to create compelling parallels between the Turkish and the American spheres, opening a transnational or a "bicultural" dialogue (ibid.). I argue this is the case with On the Road to Baghdad as well: Sufism, too, finds its place among the elements that compellingly locate the novel in an American framework and, more specifically, in the framework of American postmodernism. 
To begin with, Gün's choice to publish a novel that can be read as a Sufi tale is not surprising when considering the American and Turkish literary markets in the Nineties, where Gün's novel appears to be part of larger trends and needs to be contextualized. In her 2000 article "Spiritual Consumption in the United States: the Rumi Phenomenon," Amira El-Zein writes that "for decades, there has been a tremendous amount of publishing in the States on the work of [Rumi]" (71). Academic translations of Rumi have been available since the early $19^{\text {th }}$ century, but the late $20^{\text {th }}$ century saw an enormous popularization of Rumi due to "non-academic" translations that significantly simplified the pre-existing ones in favor of non-specialist readerships (73). One of the most prolific interpreters of Rumi is Coleman Barks, who published his first adaptations in the Seventies, and in 1994, El-Zein reports, Publishers' Weekly announced that Rumi had become America's bestselling poet. By 2000, Barks' adaptations had sold more than 250.000 copies. From such a perspective, On the Road to Baghdad, published in 1991, appears as part and parcel of an American literary phenomenon that revolved around the popularization and domestication of Sufism. The extent to which Gün participated in this domestication will be clarified later. My concern now is illustrating how the representation of Sufism in the novel is not only deeply embedded in the American literary market, but in the Turkish one as well.

In 1990, Orhan Pamuk published The Black Book in Turkey. The first English translation by Gün followed in 1994, three years after the first edition of On the Road to Baghdad. Striking similarities emerge between these two representative works of postmodernism, the most relevant for the purpose of this analysis being that both trace the unfolding of an individual's spiritual quest and can be read as Sufi tales. In both novels, the Sufi path is identical with the search of individual and collective identities. Konuk describes On the Road to Baghdad as the promoter of a dialogue between the Turkish and the American literary corpuses, able to convey the idea of cultures and identities in process (Identitäten im Prozeß 91 ). On a similar note, Brent Brendemoen speaks of an "identity" theme in The Black Book, which "slowly takes a turn in the Sufi direction" (Brendemoen n.p.). Like in On the Road to Baghdad, the search for the Sufi mystery in The Black Book gradually gains prominence and only towards the end of the novels does the reader realize that the trajectory followed by the protagonist corresponds to a Sufi path.

These and other references to the Ottoman tradition contributed to the problematic reception of the two novels in Turkey. "Turkish readers today," Brendemoen notes, "are so secularized and devoid of knowledge about Sufi literature that most of them would not be able to appreciate the Sufi aspects of the novel" without the 
necessary explicatory paragraphs Pamuk introduces in the course of The Black Book (Brendemoen n.p.). Pultar makes a similar point when discussing the lack of enthusiasm with which Gün's novel was received in Turkey, blaming it on its distinctly Ottomanesque quality: "Turkish readers did not have much taste for the Eastern matter, preponderant in the novel, which they tended to identify with the paradigm they had formally left behind, first with the edict of Tanzimat in 1839, then even more vigorously with the establishment of the Republic in 1923" "“Travelling Biculturalism" 49). Pamuk and Gün infuse their postmodern novels with Ottoman culture and spirituality, which the Turks had learned to associate with "lack of rationality, [...] downright ignorance or primitivism" (ibid.) in the last decades of the Ottoman Empire and the Kemalist era.

Finally, neither Gün nor Pamuk hesitate to address the issue of plagiarism. The continuous references to other works of literature, Bredemoen argues, make The Black Book a "metanovel" (Brendemoen n.p.), adding that the book is permeated with a profound discussion of the theme of plagiarism, considering that one of the main characters, the columnist Celâl, "has taken (or 'stolen') the themes of most of his articles from Sufi poets" (ibid.). The word 'stolen' figures prominently in On the Road to Baghdad, whose subtitle is A Picaresque Novel of Magical Adventures, Begged, Borrowed and Stolen from the Thousand and One Nights. In his article "Authorship in Sufi Poetry," Frishkopf insists on how central an intertextual "fabric of quotations" is to Sufi authorship, where the individual author renounces his/her creative autonomy by purposefully drawing from a vaster, interconnected textual repertoire.

On the whole, Gün's and Pamuk's novels similarly engage with Sufi spirituality, which gains paramount importance on the levels of content, reception, and authorship. Viewed from such a perspective, the Sufi elements in On the Road to Baghdad simultaneously anchor the novel in an American context and in a Turkish one. On the one hand the enormous interest for Sufism awakened in the U.S. by a new wave of Rumi translations, which reached its peak in the Nineties, strengthens the American frame around Gün's Sufi novel. On the other hand, the clear connections between On the Road to Baghdad and The Black Book ground it in the Turkish literary market. The different reception and understanding of Sufism in Turkey and the United States in the Nineties also deserve to be emphasized. While, as mentioned earlier, a Sufi novel published in the United States in the Nineties could hope to ride the wave of the Rumi phenomenon, Turkey's reaction to a romanticization of Islamic mysticism such as the one offered by Gün would be far less predictable and much more discordant. As I mentioned earlier, the Kemalist ban on Sufi schools and lodges had translated into the rejection of 
Islamic mysticism as backward superstition, but at the same time the cultural and political movement of neo-Ottomanism attempted to restore the dignity and prestige of the country's Islamic tradition.

Having clarified the relevance of Sufism in establishing On the Road to Baghdad as a transnational Turkish American work, I shall now focus on how the novel secularizes Sufism for American readerships and explores the specific connection between Sufism and American postmodernism. By so doing, I hope to mitigate the irreconcilability between Sufism and postmodernism, showing that Sufi elements contribute, along with other aspects, to locating On the Road to Baghdad in the American cultural context.

\section{Secularized Sufi elements in On the Road to Baghdad}

In the initial part of the novel, the domestication of Sufism for $20^{\text {th }}$-century American readerships goes hand in hand with irony. Disguised as a boy, Hürü becomes a page at the court of Sultan Selim. Her permanence at court is described through the terminology of American higher education. Activities such as music and wrestling appear as subjects on Hürü’s schedule: "she never received more than a passing grade in physical education, for which she expected Selim to thrash her" (50). Additionally, Hürü studies horticulture at the "Mevlana Institute," where she is eventually offered a "fellowship" (52). There, Hürü learns the art of cabbage farming from an elderly dervish who functions as a confidante and with whom Hürü discusses her love issues like any college girl would. It is important to mention that Sufism in On the Road to Baghdad mostly revolves around the figure of Rumi. Other mystics are mentioned in passing, but Rumi's teachings are presented as general guidelines for Sufism as a whole: "The dervishes, whether wandering or sedentary, lived in accordance with Rumi's admonition: If you desire to increase your perception, then increase your necessity" (68). Rumi's centrality in the novel's Sufi architecture is no secondary detail, considering that the Rumi phenomenon was at its peak.

In the previous chapter, the analysis of Sufism in Halide Edip and Elif Shafak showed how both emphasized the proximity of Islamic mysticism and Christianity by defining them as essentially different from orthodox Islam, and connoting the former as religions of love, and the latter as a religion of fear. Thus, not only does the cultural distance between the United States and Turkey shrink as the two nations are projected as compatible with one another on the grounds of religion, but the association of Islam with fundamentalism is dispelled. A similar attempt to Americanize Sufism appears in On the Road to Baghdad, where Sufism 
is described as a non-violent creed and the spiritual dominion of free thinkers. Hürü’s parents, in fact,

were attracted by ideas. Sometimes they thought they were the only free thinkers left in the world. They had retained from the past a certain influence that had always been empirical: Sufi thought. [...] The ancients had been thinking unimpeded before the Big Religions set in. So, neither the Physician nor his good wife held any commerce with unexamined beliefs. Nor did they practice religion that manifested itself in brutality against others. (309)

The quoted passage is of great significance on many levels. The association between free thinking and Sufism suggests that religion, in this case, does not interfere with men's and women's capacity to think critically. Gün's version of Sufism does not demand that its adepts renounce critical thinking, as the categories of spirituality and rationality are not perceived as mutually exclusive.

The multiple narrators of Shafak's The Forty Rules of Love also reassure the reader that Sufism promotes humanism and the centrality of the individual and it does so by renegotiating the controversial identification of Islam with Submission, implied in the literal translation of the term 'Islam.' In the book, the concept of Submission is dissociated from the idea of servitude and redefined as "peaceful acceptance of the terms of the universe" (Rules 55): an idea that lays no claim on individual freedom.

Skepticism about institutionalized creeds constitutes another shared secularization strategy in Gün and Shafak. Here, the "Big Religions" (Baghdad 309) appear as restrictive models imposed on communities that allegedly allowed unimpeded thought, opening possible scenarios of cultural occupation. Furthermore, the Physician is said to take "delight [...] in hostility towards mosque and clergy" (309). As noted by many, ${ }^{82}$ the Rumi phenomenon in the United States builds on a certain diffused intolerance of established religions, and constructs Sufism as an all-encompassing form of spirituality unencumbered by the alleged abstruseness and rigidity of monotheistic religions. Coleman Barks, the author of The Essential Rumi, perpetrates this assumption by using Rumi himself: "[Rumi] says when [the mosque and the minaret and the school] are torn down, then dervishes can begin their community. So he wants us all to break out of our conditioning, be it national or be it religious or be it gender based" (Barks in Tompkins n.p.). Shams of Tabriz, Rumi's historical companion and one of the

82 See, for example, Amira El-Zein's "Spiritual Consumption in the United States: The Rumi Phenomenon" and Ali Wajahat's interview with Seyyed Hossein Nasr "Professor Seyyed Hossain Nasr: Islam’s Spiritual Science." 
narrators in Shafak's The Forty Rules of Love, urges the demolition of religion, a hindrance to the individual's path towards God comparable to "fame, wealth, and rank" (Rules 290). The incitement to figuratively tear down the spaces of orthodoxy has been used within the Rumi phenomenon to legitimize the decontextualization of Sufi poetry in order to make it more palatable to a $20^{\text {th }}$-century American readership. To such decontextualization, Iranian philosopher and Sufi scholar Seyyed Hossain Nasr responds that "in the modern world [...] there is a hatred of religion, and there are certain sectors of modern society where there is an idea that you can take the spiritual teachings of a religion outside of a religion and practice them" (Nasr in Wajahat n.p.). With this remark, Nasr connects a widespread antipathy for established religions with the tendency to uproot certain spiritual practices from their precise doctrinal backdrop, as it happened with Rumi in the United States. "Christian mystics were also Christians," Nasr adds, "they also went to Church and followed Christian laws. Hindu mystics were practicing Hindus; [... They follow the Hindu laws and so on and so forth down the line and Sufism is no exception" (ibid.).

I do not claim that Sufism did not voice the need to pursue a spiritual path that diverged from the one imposed by Islamic orthodoxy, but this aspect of Sufism is discussed with particular emphasis within the Rumi phenomenon in the United States, due to cultural characters that make American readerships particularly receptive to Sufi writings and teachings. "Creeds do not suit the American spirit," claims Harold Bloom in The American Religion, "the freedom we go on associating with solitude and with wildness does not easily assimilate with the otherness of historical doctrines" (Bloom 45). Gün's and Shafak's novels are consonant with this approach, with different intensity, but similar practices.

Another instance of domestication - or selective emphasis - is the stress on the non-violent nature of Sufism, as opposed to the aggressiveness of Islamic fundamentalism. The Sufi couple in the passage, as the narrator clarifies, stay away from religions that "manifested [themselves] in brutality against others" (Baghdad 309). In the same way, Shafak has Shams of Tabriz reassuringly distance himself and the Sufis from all forms of extremism and state that "Sufis don't go extremes. A Sufi always stays mild and moderate" (Rules 153). Shams also pronounces himself against "bigots," or Muslims who pursue a literal interpretation of the Koran:

instead of searching for the essence of the Qur'an and embracing it as a whole, however, the bigots single out a specific word or two, giving priority to the divine commands that they deem to be in tune with their fearful minds [...]. Those who have led a virtuous life will be rewarded with exotic fruits, sweet waters, and virgins. This, in a nutshell, is their notion of afterlife. (Rules 182) 
The difference between the open-minded, all-encompassing spirituality of the Sufi and the "bigots" in On the Road to Baghdad is expressed by the intrusion of two "disgraceful permanent guests" (309) in the Physician's house, namely, the Imam and Mistress Kevser, a retired school teacher. The "disagreeable couple" (ibid.) embodies a stale sense of religiosity, marked by uncritical acceptance of the established norms. The uncomfortable relationship between the two couples living under the same roof is clearly a symbol for the problematic coexistence, within Islam, of fundamentalist and moderate approaches to faith. The Physician's description of the bigot couple is reminiscent of Shams' portrayal of Islamic fundamentalists. "The Imam and Mistress Kevser," the Physician reminds his wife, "are useful to us as agents of Chaos, lest we forget [...] the powerful force of ignorant beliefs" (ibid.). Shafak's construction of Sufism as a religion of love and acceptance is easily identified as a response to post-9/11 Islamophobia in the United States. The narrator's distaste for unequivocally hideous figures of Islamic fundamentalists throughout the book characterizes Sufism as an alternative to the widespread perception of Islam as a religion of terror and violence. Gün's novel was published a decade before 9/11, but its insistence on Sufism as a non-aggressive form of Islamic spirituality is no less clear an attempt to fight a similarly destructive perception of Islam. America in the mid-Nineties was in fact very much affected by Islamic terrorism ${ }^{83}$.

The mutual antipathy between the Imam and the Physician connects to the debate between science and religion, and to discourses ingrained in Western cultures arguing for the supposed rationality of the former and irrationality of the latter. Sufism offers itself here as a middle ground. Sufi philosophy is presented as "empirical" (309) and compatible with free thinking. Moreover, the Physician and his wife refused to "[hold] any commerce with unexamined beliefs" (ibid), while the Imam and Mistress Kevser advocate "ignorant beliefs" (ibid.). On the one hand, Gün's description of Sufism talks back to the Kemalist distaste for Islamic heterodoxy, which was dismissed as superstition. On the other hand, Sufism represents a surface onto which the American controversy between scientific and religious thought may be negotiated. This aspect, not as prominent in Shafak's The Forty Rules of Love, greatly contributes to making On the Road to Baghdad a bicultural novel.

83 The terrorist attack on the Pan Am Flight 103 in 1988, the bombing of U.S. embassies in Kuwait and Beirut in 1983, and the hostage crisis at the U.S. embassy in Tehran in 1979 are only a few example of terrorists attacks directed against the U.S. in the Seventies and Eighties. 
Overlapping areas between Whitman's work and Sufism, and between modern Turkish American Sufi novels and Whitman, have been one of the foci of the previous section. On the Road to Baghdad presents another instance of this triangulation among Turkish American literature, Sufism, and Whitman. This becomes clear when examining the following passage, where Shahrazad speaks about herself as a writer.

"I am also the thousand-and-one persons I have hallucinated. I am Sinbad the Sailor. Yes, my mind has travelled to that splendid showplace of death called the City of Brass. I've seen kingdoms under the sea, kept company with vagrants, outcasts, criminals and rogues in contexts both dirty and clean, abandoned myself to a hundred love-deaths in Baghdad, to a hundred-and-one infidelities in Cairo. I've put demons and warlocks under control, been flown on jinn to China and back. I've been transformed into beasts, into Saints, Jews, Christians, into wags, ghouls, merchants both prudent and imprudent, into wastrels, hunchbacks, imps, into enchantresses with menageries of lovers, into kings whose reign is golden." (255)

Shahrazad's narration directly echoes of the all-hearing, all-seeing poetic persona of "Song of Myself," one that takes part, hears, and sees the world (or the nation) it its entirety. The passage, with its anaphora of the pronoun "I," evokes the catalogues of "Song of Myself," in which the poetic persona and author-figure is at one with the objects of his writing. The author figure in "Song of Myself" becomes all the contradictory voices he articulates: "I do not ask the wounded person how he feels," he affirms, "I myself become the wounded person" (Whitman 45). Here, Shahrazad produces an asyndetic list of literary incarnations she has encountered while writing the One Thousand and One Nights, and claims to be "the thousand-and-one persons [she has] hallucinated" (Baghdad 255). Like Shahrazad, Whitman's persona simultaneously inhabits a series of poetic objects, each one as accessible as "a change of garments" (Whitman 45).

Konuk also elaborates on this passage in her book Identitäten in Prozess. In Konuk's reading, this crucial excerpt connects the borderlessness of literature with the radical borderlessness of the self. Literature that is orally transmitted, like the tales of the One Thousand and One Nights, can hardly be anchored to easily traceable, easily localizable identities. By the same token, serial re-tellings of these legends are a substantial component of cultures that remain in process. Since Gün's novel is ostensibly based on borrowings and retellings, the identity she seeks to define in her work is also a fluid one (Konuk 151). What makes Konuk's argument particularly poignant is that, in Gün's case, the retelling of Ottoman legends that are at the basis of Turkish identity is carried out in English and within an American framework. The renegotiation of Turkey's Ottoman heritage is thus interwoven with elements from the American cultural tradition. This is 
particularly evident in the reported passage about Shahrazad's borderless self, where Shahrazad's voice resonates with Whitmanian echoes.

The Rumi verses which Shafak integrates into her writing and which echo Whitman's identificatory catalogues, alluding to a contradictory and yet complete plural consciousness, confirm Rumi's ascendant on American literature and surface in Gün's text as well. Whitman's speaker claims to synthetize oppositions by appearing "of old and young, of the foolish as much as the wise,/ Regardless of others, ever regardful of others, / Maternal as well as paternal, a child as well as a man,/ Stuff'd with the stuff that is coarse and stuff'd with the stuff/ that is fine" (Whitman 30). Yet, this does not prevent him from wondering "What is a man anyhow? what am I? what are you?" (ibid.). In the same way, Gün's Shahrazad does not discriminate among her incarnations, contradictory as they may be: she frequents "contexts both dirty and clean" and characters "both prudent and imprudent" (255); but she concludes her list of literary incarnations by asking herself "what's my mettle? My substance?" (245). While so far Shahrazad's inquiry into the authorial self ran parallel to Whitman's, her answer to the question of substance creates a stark contrast with Whitman's conclusion, and faithfully adheres to the Sufi path to self-annihilation:

"I long to exhaust all shapes of my being. As each tale falls away from me, so does another guise, another need, another dream. Someday the shell called Shahrazad will be so empty, I will see the face of God." (Baghdad 245)

In the quoted passage, Shahrazad longs for self-effacement, not necessarily as a human being, but certainly as an author. In other words, Shahrazad's conclusions are far from establishing the mythic and overwhelmingly powerful author figure that dominates "Song of Myself." If applied to the literary context of the Nineties, when On the Road to Baghdad was published, the Sufi's yearn for figurative death points instead to the postmodern concept of the death of the author. Such theoretical background will guide the following part of my analysis, aiming to locate On the Road to Baghdad in the context of American postmodernism.

\section{Sufi Mysticism and North American Postmodernism: Barth, Barthes, Gün}

The net of intertextual references linking Gün's work with American postmodernism has been explored by Kader Konuk in her article "Sufism and Postmodernism in Güneli Gün's On The Road to Baghdad." Konuk describes Gün's novel as intellectually indebted to the work of postmodern author John Barth, her teacher and mentor. Djelal Kadir made a similar point in 1992, when he wrote that Barth 
"admitted that he served as midwife in Guneli's delivery upon our writing scene" (Kadir 63). Konuk argues that On the Road to Baghdad can be seen as a response to Barth's novella "Dunyazadiad," included in his 1972 novel Chimera. According to Konuk, the figure of Shahrazad in Gün's novel and the narrator of Barth's novella, Shahrazad's sister Dunyazad, are similarly narcissistic. On the level of form, Konuk continues, both Barth and Gün's emphasis on intertextuality, selfreferentiality, pastiche, collage, and other open narrative techniques point at the exhausted state of literature (Konuk 98-99), cast as a feature of postmodernism in Barth's 1967 essay “The Literature of Exhaustion.”

In her article, Konuk also addresses the theme of Sufism in On the Road to Baghdad, concluding that the Turkish author presents Sufism as "an answer to North American postmodernism" and its unrelenting deconstruction of the Self and literature as expressed in Barth's "Exhaustion." In On the Road to Baghdad the dissolution of literary forms and authorial figures supposedly goes hand in hand with the dissolution of the self in Sufi spirituality. Gün's characters undergo a process of self-discovery within the spiritual context of Sufism which does result in a dissolution of the self - and yet it does not imply its negation or total deconstruction (Konuk 100). For this reason, in Konuk's view, Gün demonstrates her ultimate rejection of (Barth's) postmodern ideas. While postmodern literature "distinguish[es] itself from the traditional function of literature as a site for constituting meaning," Gün "presents Sufism as the archetypical remedy for questions related to the meaning of existence," positing that meaning can be found beyond deconstruction (Konuk 94). Konuk perceives Gün's text as haunted by a "fundamental contradiction": "on the one hand, indebted to postmodern narrative strategies and, on the other, motivated by questions relative to the meaning of existence" (100).

By affirming that there is a fundamental contradiction between Gün's use of postmodern narrative strategies and depiction of Sufism, and by arguing that her "recourse to Sufi mysticism demonstrates a rejection of postmodern ideas" (100), Konuk points at a constitutive incompatibility between Sufism and American postmodernism - as the former aims to achieve meaning through deconstruction, while the latter deconstructs meaning. Yet, Gün's novel may also be seen as an attempt to mediate between the Sufi and the postmodern deconstruction of the authorial figure: the former religious, the latter secular. On the one hand the Sufi strove to obtain self-effacement in a mystical sense, while the postmodern apply the idea of a mystical dissolution to literature and the demise of an overbearing authorial figure. It is my intention to build on the (dis)connection between Sufism and postmodern literature postulated by Konuk and suggest that 
the Turkish American novel On the Road to Baghdad emerges as a site where the two practices are successfully integrated and work towards similar goals. In fact, in order to strengthen his argument, Barth makes frequent references to "the mystics" and their methods (Barth 70,71). Gün's portrayal of Sufism as a strategy to find meaning in and beyond deconstruction might not be a rejection of Barth's conceptualization of literary exhaustion, nor of postmodern ideas, as Barth does not announce the total demise of literature, but its renewal in a different form.

Barth opens "The Literature of Exhaustion" stating that "the times of literature and the novel might have come to an end, but there is no necessary cause for alarm in this at all" (71). Yet, this did result in a certain measure of alarm. In the preface to a later edition of "Exhaustion," included in The Friday Book: Essays and Other Non-Fiction (1984), Barth felt the need to respond to his critics by saying that his article, much to his discomfort, had been "frequently misread as one more Death of the Novel and Swan-Song of literature piece" (Barth 64). This led to the publication of a second essay, "The Literature of Replenishment," which lays emphasis on a potential renewal of literary forms, rather than on their exhausted state. In "Replenishment," Barth laments the fact that "a great many people [...] mistook me to mean that literature, at least fiction, is kaput: that there is nothing left for contemporary writers but to parody and travesty our great predecessors in our exhausted medium - exactly what some critics deplore as postmodernism. This is not what I meant at all" (Barth 205).

It is undeniable that, even in "Exhaustion," Barth does point at new avenues of literary experimentation. More specifically, he suggests that, in order to continue to exist, literature should learn from Borges and from the mystics. "[Borges'] artistic victory," according to Barth, lies in doing "what the mystics do," in so far as he "confronts an intellectual dead end and employs it against itself to accomplish new human work" (Barth 70). This statement resonates with the possibility of producing meaning beyond annihilation, which permeates both Sufi mysticism and Barth's understanding of postmodern literature. The parallel between the postmodern author and the mystics reappears one page later, again in reference to Borges. "[Borges' work] illustrates [...] how an artist may paradoxically turn the felt ultimacies of our time into material and means for his work - paradoxically, because by so doing he transcends what had appeared to be his refutation, in the same way that the mystic who transcends finitude is said to be enabled to live, spiritually and physically, in the finite world" (Barth 71, emphasis in the original text). Like the postmodern author survives the "felt ultimacies of our time" (ibid.), among which his figurative destruction and burial by the hand of French philosopher Roland Barthes and others, the mystic acknowledges and 
even accelerates the finitude of his mundane existence, and only then does s/he experience unity with God - the only life worth living.

When "the author enters his own death," wrote Barthes, "writing begins" (Barthes 2), and it is hard not to think of the concept of self-denial in Sufi spirituality and writing. Frishkopf confirms the parallel between Sufi mysticism and postmodern literature, speaking of Sufi authorship as "postmodern": "Authorship in Sufi poetry appears as surprisingly postmodern. [...] It [...] displays most clearly the literary attributes of postmodernism: reader determination of meaning; intertextuality; the decentering of the autonomous author" (Frishkopf 78, 79). There are powerful connections between Sufism and postmodernism, especially with regards to the marginalization of the individual author-God, and there is enough evidence to claim that the two currents are, if not connected, at least not incompatible. Konuk's identification of Gün's Sufism with a rejection of postmodern ideas is pertinent. It is necessary to specify whose postmodern ideas Gün is antagonizing by posing questions regarding the meaning of existence. My contention is that it is not John Barth's avant-gardism that On the Road to Baghdad is objecting to with its use of Sufism, but rather Roland Barthes' similar positions, positions Barth is also ideally contradicting.

Both Barth and Barthes, in their coterminous theoretical essays "The Literature of Exhaustion" and "The Death of the Author," touch upon the three distinguishing features of postmodernism indicated by Frishkopf as leading to a triangulation with Sufi writing and spirituality: "reader determination of meaning; intertextuality; the decentering of the autonomous author" (Frishkopf 78, 79). What differentiates the two theoretical approaches to postmodernism is exactly the search for meaning, and its ultimate potential for deconstruction. On the one hand, in "The Death of the Author," Barthes dreams of writing practices that ceaselessly and systematically evaporate meaning:

Thus literature (it would be better, henceforth, to say writing), by refusing to assign to the text (and to the world as text) a "secret": that is, an ultimate meaning, liberates an activity which we might call counter-theological, properly revolutionary, for to refuse to arrest meaning is finally to refuse God and his hypostases, reason, science, the law. (Barthes 5)

Barth's figurative killing of the author is the first element of a chain reaction that would lead to the erasure of ultimate meaning, of God, and of other categories that up to that point had been intended to offer meaning. On the other hand, Barth invites the postmodern author to survive his/her finitude and metaphorical death in order to "accomplish new human work" (Barth 70), and, like the mystics, access a different mode of existence where one's ability to produce meaning would possibly be restored. Konuk is right when affirming that Gün 
"posits Sufism as the archetypical remedy for questions related to the meaning of existence" that postmodernism dismisses (Konuk 99). Yet I propose that it is not "North American postmodernism" (Konuk 100) that Gün responds to by her use of Sufism, especially not Barth's. On the contrary, Gün seems to approvingly "nod" to Barth (Pultar 55), using American postmodernism as a frame of reference onto which she grafts her transnational Sufi novel.

There is little doubt that Gün's On the Road to Baghdad is an eminent representative of Turkish American literature as a transnational phenomenon. The novel presents its American readership with a domesticated version of Sufism, interspersed with more intricate references to Islamic doctrine and Ottoman folklore - the impenetrable "Eastern matter" (49) Pultar mentions as one of the causes for the book's poor sales. Parallel to that, the book lays a strong claim for inclusion in the American postmodern tradition by entering a literary conversation with one of its seminal authors. This section offered an alternative reading of Sufism in On the Road to Baghdad, one that hoped to emphasize the relevance of the Sufi theme in the novel and argued in favor of its compatibility with the dictates of American postmodernism.

Sufism gains paramount importance in On the Road to Baghdad as a terrain of transnational convergences. The self-annihilation of the Sufi adept in God finds a close correspondence in Barth's urge to do "what the mystics do" and embrace literature's dead end to inject it with renewed life (Barth 70). Gün's text participates in the postmodern debate over the death of the author by having her two protagonists and author-figures - Hürü and Shahrazad - disappear at the end of the novel in miraculous circumstances: "[Hürü] was changed [...] into an unbearably brilliant green light. And where Shahrazad stood, a blue light appeared, growing in intensity and brilliance until the two prodigious lights merged into one single blue-green fire" (Gün 353). Like Barth, Gün embraces a purposeful approach to the death of the author by specifying, in the novel's conclusion, what follows his/her disappearance, namely, invisible feminine voices made visible. "Sufi knowledge," a grandmother tells her granddaughter at the end of the book, "is as silent and secret as our woman knowledge" (ibid), and encourages her to hand down the story of Hürü and Shahrazad to "one of her granddaughters [...] the one who understands" (ibid.). Like Edip before her and Shafak after her, Gün hypothesizes the substitution of a male-dominated tradition of the written word with a strongly matrilinear history, supplements Turkish historiography with Ottoman folklore, and grafts mystic heterodoxy into a predominantly orthodox tradition. In The Black Bookan important interlocutor for Gün and a representative of Turkish postmodernism (Göknar, "Ottoman Theme" 34,35) - the narrator agrees with Barthes on "refusing 
to assign to the text (and to the world as text) a 'secret' [and] an ultimate meaning" (Barthes 5), as Galip eventually becomes aware that his agitated search of Celâl, the secret hidden behind his writings, and a meaning behind the faces of his compatriots are mere delusions. By contrast, Barthes and Gün use mysticism to overcome the joint demise of literature and the author, pointing at different literary scenarios that are to follow. 



\section{Ottoman Nature: Natural Imagery, Gardens, Wells, and Cultural Memory in Republican Turkey}

Natural metaphors offer a considerable insight into processes of identity-making and identity-writing. The notion of hybridity is derived from botany, ${ }^{84}$ as are the concepts of roots and transplantation. Franco Moretti speaks of the modern novel as "a wave that runs into the branches of local tradition" and likens the development of national and world literature to trees and waves respectively (Moretti 67). In a footnote, Moretti also reminds his reader of Miyoshi's "grafting process," Schwarz's "implantation of the novel," Wang's "transplantation of Western narrative typologies," and Belinski's definition of the Russian novel as "a transplanted rather than indigenous growth" (Moretti 67-68, emphases in the original text).

The study of garden spaces and botanic symbolism in literary texts has been very fruitful in the field of postcolonial ecocriticism: recently, scholars inquired into the multifarious relationship between man and the environment in colonial and postcolonial contexts. Examples of such scholarly interest in the representation and significance of gardens in New Literatures in English are Helen Tiffin and Graham Huggan's Postcolonial Ecocriticism, published in 2009, and Projections of Paradise: Ideal Elsewheres in Postcolonial Migrant Literature (2011), by Helga Ramsey-Kurz and Geetha Ganapathy-Doré, a collection of essays on the theme of paradise which engage misconceptions of a mystic, precolonial, Edenic garden. These publications show nature and the notion of 'paradise' as arenas where colonial conflicts are re-enacted, and where Western conceptualizations of the East are re-evaluated and subverted. Among the narratives these texts aim to dismantle, one finds the precolonial paradise: a pristine space featuring a union of man and nature that Western colonialism has irremediably destroyed.

This recent branch of postcolonial approaches to botanic imagery helps to illuminate the function of gardens and natural elements in Turkish American literature. In brief, the following section sheds light on the significance of nature in this literature, aiming to demonstrate that floral and faunistic elements take up specific functions connected with a search for identity in post-imperial

84 In biology, genetics, and botany, a hybrid specimen is the offspring of parents belonging to different species. The term has now become a recurring trope in several other disciplines, and it indicates an element of mixed origin. 
Turkey. In fact, even though the Turkish American novels I will discuss in this chapter were written in the early 2000s, they focus, at least partially, on the delicate historical moment (the first half of the $20^{\text {th }}$ century) when Turkey ceased to be the center of an empire and became a republic. Nature - including images of gardens, courtyards, plants, animals, and other non-natural but nature-related symbols such as wells and a pomegranate brooch - is used as a device to tackle themes such as identity, migration, and cultural memory. Gardens in particular function as 'border areas' in turn-of-the-century Turkey, perched between Ottoman exoticism and the advancement of modernity. The disappearance of gardens - cast as remnants of Ottoman architecture - constitutes a synecdoche for the disappearance of Ottoman cultural memory in the country's passage from empire to republic.

Ultimately, like many others tropes and motifs analyzed in the course of this volume, natural imagery articulates a response to Kemalist ideology by gesturing at a sudden rupture with the country's Eastern, Islamic, and imperial components for the sake of a Western ideal of progress. My argument builds on Foucault's conviction that discourse can be constructed when singularities are elevated to the status of concepts and allow for a rationalization of their context. This is the case for 'Ottoman nature' in Turkish American literature, within which, to cite Foucault, "it is things themselves [...] which imperceptibly turn themselves into discourse as they unfold the secret of their own essence" (Foucault, "The Order of Discourse" 66). The analyzed novels present images of trees, fruits, birds, flowers, and gardens as densely connoted cultural objects that open up a complex universe of meaning and contain within themselves discourses on the empire and the nation.

Primary sources in this chapter will not be organized in a chronological order. In fact, Pamuk's novel, published in 1990, ${ }^{85}$ precedes Croutier and Shafak by more than a decade. Elif Shafak's The Bastard of Istanbul (2007) and The Saint of Incipient Insanities (2004) will be discussed first as they make the most extensive use of garden symbolism. A reason for that is the author's fascination with Sufi literature, which draws from a considerable repertoire of botanic symbols. In her work, Shafak does not replicate the Sufi symbols proper, whose nature was principally mystical; she rather imitates the structure of Suf literature more generally, creating her own net of botanic and ornithological metaphors in order to discuss questions of identity and cultural memory in the context of republican Turkey.

85 Page numbers relative to The Black Book in this study refer to Maureen Freely's 2006 translation. 
By doing so, Shafak also establishes a continuous correspondence between modern Turkey and its Ottoman heritage, of which Sufism is certainly a prominent part, undermining the Kemalist rupture with the country's imperial past. Alev Lytle Croutier's Seven Houses (2002) positions itself between Shafak's extensive use of garden symbolism and Pamuk's minimal, condensed one. Through the destruction of two gardens, Seven Houses stages the painful disappearance of the Ottoman world and the advancement of Westernization. Finally, the choice to discuss The Black Book by Orhan Pamuk as the last element of my analysis is due to the fact that it presents a most accomplished garden narrative (perhaps laying the basis for Shafak's and Croutier's discourses on Ottoman nature) and creates the most compelling interrelation among the various elements that compose it. Although Pamuk's work does not qualify as Turkish American literature by my definition, integrating The Black Book into an analysis of nature in Turkish American literature presents us with the possibility to compare the relevance of similar literary tropes in the Turkish and Turkish American literary scenes. In these terms, a comparison of Croutier's and Pamuk's gardens and wells will prove helpful, as both authors connect these spaces to cultural memory, but to different ends.

\section{American Nature and Turkish American Natural Symbolism}

When reflecting on the Turkish American use of natural symbols and gardens, it is important to note that the frame of reference is not the American tradition of pastoralism. The gardens of Turkish American literature are prominently urban gardens and courtyards, and natural symbols employed in the text are generated and imagined within an urban context by Istanbulites or American characters who inhabit the city. No "wilderness cult" or "inchoate longing for a more natural environment" enter the Turkish American imagination (Marx 5). The dissimilarity of these two garden traditions, the Turkish and the American, prevents the Turkish American characters in Seven Houses from deeply connecting with their Turkish matriarch's garden, failing to comprehend her attachment to it. In his seminal work The Machine in the Garden, Leo Marx explores garden representations in American literature and culture, defining the garden as a key symbol of the American imaginary. Marx describes American garden imagery as principally connected to the pastoral ideal and to the romanticization of rural life. According to Marx, soon after its discovery America harbored dreams of "retreat in an oasis of harmony and joy" (Marx 3). Afterwards, a kind of natural escapism started to permeate the American sensitivity, which regarded urban life with skepticism and yearned "for a simpler, more harmonious style of life, an existence 
'closer to nature"' (Marx 5). The theme of a withdrawal into nature, Marx wrote, is central to a remarkable number of American authors.

Postcolonial Studies offer a more suitable theoretical framework for Turkish and Turkish American gardens. In the postcolonial tradition, garden imagery is contingent with the myth of the colony as an untouched Eden and projects the colony as the opportunity for a new beginning in nature as well as a space open to exploitation and predation. Postcolonial writers use the trope of the ravaged garden, or the fallen paradise, to document the impact of colonialism on their homeland. Environmental exploitation is, in many cases, a metonymy of the exploitation logics of imperialism at large. Parallels between the demise of the postcolonial garden and the demise of Ottoman nature in Turkish American literature, annihilated by the republic's vision of a more urban Istanbul, are evident and will be explored in this chapter. Nevertheless, postcolonial writers are also invested in dispelling the exoticist representation of the colony in the European imagination: as Said observes, the postcolonial is a "de-exoticizing category" (Said in Huggan 20). By contrast, some of the Turkish American nature analyzed in this study appears to be hyper-exoticized, but this does not exclude the possibility of a postcolonial reading of Ottoman nature. Postcolonial texts, in fact, also qualify as "exotic objects circulating within a metropolitan-regulated economy of commodity exchange" (ibid.) that present a problematic use of selfexoticism and "actively manipulate exoticist codes of cultural representation in their work" (ibid.). The American and the postcolonial frameworks should therefore be kept in mind, but the uniqueness of the material at hand calls for a more nuanced analysis.

In all the analyzed novels, representations of nature either replicate or condemn the depiction of the United States as a model for Turkey's republican future and the Kemalist modernization project. Additionally, Shafak's fig tree, birds, and pomegranates serve the purpose of connecting and comparing the Armenian and Armenian American processes of identity-making and hint at the possibility of re-enacting the cultural diversity of the Ottoman Empire in the Unites States, where dispersed Ottoman minorities can re-agglomerate into families and communities. In Seven Houses, the Americanization of Turkish culture is embraced as one substantial element of the Turkish collective self in the new millennium. Hence, nature in Turkish American literature invites a reflection on the role of the United States in the creation of Turkey's national identity in the passage from the empire to the republic.

In their different representations of gardens, the texts present a variety of reactions to Americanization. Shafak's skeptical stance regarding Turkey's impetuous 
Westernization and its open contempt for its Ottoman legacy curiously interferes with her portrayal of the U.S. as the heir of Ottoman multiculturalism. Croutier's Ottoman aristocrats seem relieved at the loss of their anachronistic villas, orchards, and estates and long to make a fresh start in an Americanized world. The characters' attitude of acceptance must not be confused with fatalism vis-à-vis the advancement of Westernization, it rather expresses a spontaneous optimism based on the view of Turkish identity as the result of different cultural legacies. Finally, Pamuk's The Black Book is the only text forwarding openly anti-imperialistic positions, clearly referring to Americanization as cultural imperialism, and blaming it for plunging Turkey into a condition of 'national amnesia.'

\section{Fig Trees and Pomegranates: The Shaping of Post-Genocidal Armenian Identity in Elif Shafak's The Bastard of Istanbul}

\section{Fig Trees: Beyond Negative Identities}

The encounter with the fig tree in The Bastard of Istanbul occurs towards the end of the novel, when Aram, an Armenian Istanbulite, fantasizes about a fig tree tattoo.

The tattoo I would like to have is a gorgeous fig tree. But, unlike other trees, this one is upside down. My fig tree has all its roots up in the air. Instead of the earth, it is rooted in the sky. It is displaced but not placeless. (Shafak, The Bastard 254)

The image of the upturned fig tree explicitly connects to the realm of ethnicity and belonging. The theme of 'placelessness' recurs frequently in Shafak's work: Her fiction is replete with figures of displaced individuals who problematize the notion of national belonging. A celebration of placelessness appears, for instance, in The Forty Rules of Love, where Shams of Tabriz renounces geographical affiliation and declares that "[his] place is placeless, a trace of the traceless" (Forty Rules 183). In one of her numerous interviews, Shafak resorts to the figure of the upturned tree to describe her own past: "Sometimes I feel like a nomad lacking solid space. According to an old Islamic narrative there is a tree in heaven that has its roots up in the air. Sometimes I liken my past to that tree" (Shafak, "Linguistic Cleansing" 1). Shafak is probably referring to the Țūbā Tree, a mythological tree that grows in heaven with its roots upwards. ${ }^{86}$ Yet, Aram's curious idea

86 Shafak is probably referring to the Țübā Tree, a tree that grows in heaven with its roots upwards: "In [Heaven's] courtyard's riven center, planted he the Tuba-Tree;/ That a tree which hangeth downward." Yaziji-Oglu "The Book of Mohammed: The 
and the cultural implications it evokes introduce a complex scenario that calls for a more detailed analysis.

The fig tree in all its varieties makes its appearance in numerous cultural and religious traditions, including Hinduism, Buddhism, Islam, Judaism, and Christianity. In addition to the Țūbā Tree, the Ashvattha Tree ${ }^{87}$ or Tree of Life of Hindu mythology presents the most striking resemblance to the fig tree pictured by Aram. The Ashvattha or Bodhi Tree is itself a variety of fig tree (ficus religiosa) and appears often in Hindu texts as a sacred tree and object of veneration. The Bhagavatgita describes it as growing with its roots in heaven and its branches hanging downward. This is a mystic interpretation of botanic characteristics proper to many varieties of the ficus genus, which generally tend to grow downward and develop aerial roots, according to what goes by the name of 'geocarpic' growth. The peculiar growth of geocarpic species of ficus, such as the bodhi or the bayan, is rich in suggestive interpretations. In Hindu Mythology, the Ashvattha Tree symbolizes the achievement of immortality through the sacrifice of the mortal body. Inspired by the almost parasitic nature of geocarpic fig trees, which strangle the host trees they grow upon, the myth of the Ashvattha Tree requires the death of a sacrificial victim willing to be suffocated by the Ashvattha Tree and eventually become the tree itself.

The episode involving Aram's tattoo acquires new meanings if read in the light of Hindu mythology. ${ }^{88}$ Both trees - Aram's and the Ashvattha Tree - are fig trees, and not simply upturned, but rooted in the sky. As a consequence, the symbolism with which Aram invests his personal fig tree - displacement, and yet not placelessness - is multilayered. First, the fig tree is a transcultural symbol that simultaneously anchors him in different neighboring cultures. Second, it creates an indissoluble connection between Aram, an Armenian Christian, and the seemingly oppositional Turkish Islamic context where he was raised and feels at home. Third, the first two elements ultimately intertwine with the mythology

Creation of Paradise.” See also George Lechler, “The Tree of Life in Indo-European and Islamic Cultures."

87 The spelling of "Ashvattha" has been derived from David L. Haberman, People Trees: Worship of Trees in Northern India.

88 Shafak is certainly familiar with Hindu mythology. She is an expert in religion, especially on mysticism, which is prominent in her fictional as well as non-fictional writing. Her most recent novel, The Architect's Apprentice (2015), is partly set in India. Whether the Ashvattha Tree was on her mind when she wrote The Bastard, is hard to assess. Yet, this parallel speaks to the efficacy of the upturned tree as a transcultural symbol, and to its resonance within the context of displacement and belonging. 
surrounding the Tree of Life, namely, immortality through sacrifice. Such interaction of different symbolic meanings connects the Tree of Life with some relevant aspects of the Armenian question in republican Turkey, as Aram is, in fact, Armenian. These aspects are, first, the feeling of displacement of the individual represented by the upturned tree, whose roots are in the contested idea of the Armenian nation, but who nevertheless feels grounded in a diasporic dimension that transcends national borders. Second, a component of pain, represented by what is known as the Armenian genocide: the forceful relocation of Armenian populations in 1915, which resulted in the death of over a million Armenians (Konuk, East West Mimesis 4). Third, a component of immortality represented by the necessity to perpetuate Armenian identity and memory in a post-genocidal era.

Aram's identification with the overturned fig tree pushes the discussion further. Aram's wish to have the fig tree tattooed on his own skin $^{89}$ reminds the reader of the sacrificial human being at the base of the myth of the Ashvattha Tree, who sacrifices himself and literally becomes the tree. In order to obtain the tree's wisdom, his physical body will have to suffer a painful death, whereas his spiritual nature will be immortalized in the tree and represent a source of wisdom for humanity. What correspondence does the mythical sacrifice of the man becoming the Ashvattha Tree find in the story of Aram, and, more generally, how does it influence the way the Armenian question is dealt with in The Bastard of Istanbul?

Most importantly for the purpose of this study, the fig tree also draws attention to the different ways in which - at least in Shafak's understanding - Armenians and Armenian Americans construct individual and collective identities. Categories of mobility and immobility can be brought to bear on these divergent constructions, as Aram's fig tree with roots up in the air gestures at the refusal to be stubbornly rooted into arbitrary concepts of nationhood and the rejection of geographical and metaphorical immobility. On the one hand, Armenian Istanbulites are seemingly immobile, as they still reside within the former territories of the Ottoman Empire. Aram himself, for example, admits that "[his] family history in [Istanbul] goes back at least five hundred years" (253). In The Bastard, however, Istanbul is

89 Zeliha, Aram's partner, speaks of Aram and the tree as if they were one being. She immediately understands that the fig tree would be a metaphor for Aram's own condition: "I'm fine with Aram's wish to have his roots up in the air" (254). 
often represented as a mobile city, compared to a boat ("Istanbul is not a city, [...] it is a cityboat. We live in a vessel" 196) or to a conglomerate of highly unstable elements ("the city is a gummy, almost gelatinous entity at this moment, an amorphous shape half-liquid, half-solid" 214). Armenian Americans, by contrast, have left the territories of the Empire and live in a diasporic dimension, which would characterize their experience as one of mobility. Yet, in "The Return of the Ghetto," Shafak defines Turkish migrants abroad as "far more nationalist, conservative, reactionary and religious than Turks in Turkey," exposing their inflexibility as a consequence of their geographical and emotional distance from the quickly evolving, ever-changing society in the homeland (Shafak n.p.). ${ }^{90}$ Similarly, Armenian Americans in The Bastard appear to be excessively dependent on the image of the Turk as colonial oppressor and lack the daily interaction that Istanbulite Armenians have with their Turkish neighbors. Thus, Shafak depicts Istanbulite Armenian as mainly interested in facilitating a peaceful coexistence than in keeping the historical enmity between Turks and Armenians alive in the diaspora and handing it down to future generations.

In The Bastard, Armenian American characters define themselves through their rage against the former colonial oppressors, using it as a source of selfvalidation and as powerful social glue. While Armanoush, whose family emigrated to the U.S. in order to escape persecution, is tormented by the choice between embracing her Armenianness and the burden of pain and loss it entails, or denying it for the sake of assimilating to the majority, Aram fully identifies with his ethnic background while at the same time cherishing the possibilities Istanbul's multiculturalism offers in term of peaceful coexistence. The tree symbolism Aram literally incarnates represents an autonomous Armenianness that refuses to define itself through cultural hatred and, instead, moves on to a more integrative approach to Turkish culture.

Ultimately, Aram's notion of Armenianness is tightly bound to the city of Istanbul and the cosmopolitan nature of the Ottoman Empire:

"This city is my city. I was born and raised in Istanbul. Armenian Istanbulites belong to Istanbul, just like the Turkish, Kurdish, Greek and Jewish Istanbulites do. We have first managed and then badly failed to live together. We cannot fail again." (254)

90 It is legitimate to argue that this viewpoint does not apply exclusively to Turkish migrants, but to migrant communities in general, including the Armenian. In fact, in her article Shafak notes that the conservatism of Turkish migrants is not due to their "Turkishness," but to their "immigrant psychology" ("Return of the Ghetto" n.p.). 
The fig tree - a transcultural, transreligious symbol that crosses numerous cultural traditions - functions as a call for multiculturalism in the Ottoman Empire's former territories. It is reminiscent of Moretti's tree as a synthesis of cultural unity and diversity, and a metaphor of how one springs from the other as in "one tree, with many branches" (Moretti 67). Offering a commentary on Aram's condition of displacement, but not placelessness, the fig tree indicates the necessity for diasporic Armenians to stop defining their national belonging through the legacy of the imperial conflict with Turkey, but rather in terms of peaceful coexistence. Moreover, through the metaphor of the fig tree, Shafak invokes categories of belonging that enable the individual to express affection towards one's place of birth without translating it into rigid nationalism. Perhaps, the figure of Aram can be best explained through Kwame Anthony Appiah's concept of "rooted cosmopolitanism." Rooted cosmopolitans, explains Appiah, can either reside in their country of birth or abroad, but from both standpoints they "nurture the culture and politics of their home" (Appiah 619) without embracing the logics of nationalism, which in Appiah's reading would require uncompromising and uncritical adherence to such politics (Appiah 619-620). By contrast, the patriotism of rooted cosmopolitans expresses itself in the form of "moral aspirations" for their countries (620). Aram, like Appiah's rooted cosmopolitans, is "attached to a home of [his] own, with its own cultural particularities, but taking pleasure from the presence of other, different places that are home to other, different people" (618). Aram cherishes his native Istanbul especially for its potential to simultaneously be the home of "other, different people" as well as his own.

\section{Pomegranates: Under two Empires}

Similar to the fig tree, the pomegranate is also a transreligious, transcultural symbol. Pomegranates are used mainly as decoration in Judaism on religious garments and containers for the Torah scrolls; the pomegranate tree is mentioned in the Koran as one of the trees of paradise, and appears in Christianity in association with Mary. In the Classical and Christian traditions pomegranates are mostly a symbol of fertility and femininity. This is due to the shape of the fruit, recalling a womb containing many seeds; in Greek mythology the wifely goddesses Hera, Zeus' spouse and patroness of domesticity, and Persephone are usually represented holding a pomegranate. Persephone presides over the seasonal cycle, as the myth depicts her commuting between the underworld, the residence of her husband, and the upper world, the dominion of her mother Demeter, goddess of abundance. According to the myth, when Persephone visits the underworld in winter, her mother's mourning causes nature to wither and 
decay, whereas during the rest of the year, when mother and daughter are reunited, the world is reborn into spring and summer. These combined references to maternity, death, and rebirth were inherited by the Christian tradition in the figure of Mary, often portrayed holding a pomegranate in traditional iconography. In association with Mary, the pomegranate is both a reference to her divine maternity and the passion of Christ. The redness of the seeds, contained in a fleshy envelope, bring to mind a ravaged body and the effects of a violent death, yet, the abundance of seeds suggests the possibility of rebirth as the fruit is often seen in connection with the death and resurrection of Christ. Thus the ideas of fertility, death, and rebirth associated with the pomegranate goddesses in Greek mythology converge in the figure of Mary holding the pomegranate. A similar combination of symbolic functions appears in the Armenian subplot in The Bastard of Istanbul. Once again, Shafak employs a botanic image belonging to the major monotheistic religions - but also common to other cultural universes such as the Hindu, the Parsi, and the the Egyptian (Verotta et alii 304) - to illustrate aspects of the Armenian experience in Turkey. Most significantly, the pomegranate is the symbol of the Armenian nation, where it also represents fertility, abundance, and marriage (Verotta et alii 304).

In The Bastard, the Armenian poet Hovhannes Stamboulian presents his wife, pregnant with their third child, with a pomegranate brooch:

He had also purchased [...] a graceful brooch in the shape of a pomegranate, delicately smothered with gold threads all over, slightly cracked in the middle, with seeds of red rubies glowing from within. It was a deftly crafted piece by an Armenian artisan in Sivas, he had been told. Hovhannes Stamboulian bought the piece as a present for his wife. (226)

Considering the pomegranate symbolism illustrated so far - including femininity, fertility and maternity - the brooch is easily explained as a well-wishing gift from a husband to his pregnant wife. Nevertheless, this only means scratching the surface of the rich textual significance of the pomegranate brooch in the Armenian subplot, as the parallel between the history of the Armenian family and pomegranate symbolism will eventually deepen.

Historical developments disturb Hovhannes Stamboulian's family idyll. In the days of the Armenian deportations, a group of Turkish soldiers burst into Stamboulian's house, seizing him, his wife, and their children. The death marches prove fatal to the woman and her unborn child and every trace of Stamboulian himself is lost. The shattering of the Armenian household coincides with some crucial aspects of pomegranate symbolism in the Christian tradition: as anticipated, the painful process of breaking the fruit's peel to reach the seeds, opening 
up a soft, red interior establishes a connection with acts of physical violence and is related to the passion of Christ. In the hands of Mary or Jesus as a child, a broken or bursting pomegranate symbolizes the Virgin's maternity, but also hints at the violent death in store for her son. The brooch - "slightly cracked in the middle, with seeds of red rubies glowing from within" - carries a similarly ominous presentiment for the people involved, and the fragmentation of the household it was meant to protect.

The two apparently contrastive symbolic values attached to the pomegranate in the Christian tradition are thus combined in the fate of the Armenian mother and her shattered family. If, in the hands of Mary, a pomegranate signifies both motherhood and blood-spilling, the pomegranate brooch has the same function in the text: meant as a well-wishing gift to a pregnant woman from her wellintentioned husband, it foreshadows the death of its carrier and her unborn child. Evidently, the pomegranate symbolism in The Bastard of Istanbul transcends the private dimension - the fragmentation of an Armenian family due to the Armenian genocide - to enter a wider, collective one: the fragmentation of the Armenian population under the same circumstances. This step occurs after both Hovhannes Stamboulian and his wife have been killed on death marches, and their children have been separated; the son is brought to the United States as a refugee, whereas the daughter is rescued by a Turkish family, raised as a Muslim, and eventually married off to a Muslim man.

If in the first place pomegranate symbolism was used to address the issue of genocide through the ominous double implication of the pomegranate brooch, in the second part of the Armenian flashback the pomegranate brooch bears connections to the Armenian diaspora. Anticipating the destiny of Christ, the pomegranate also includes a hint to his resurrection and the hope for a kingdom to come. In other words, not only is the pomegranate an allusion to Christ's birth and death, but, most importantly, to his re-birth. This particular aspect of pomegranate symbolism is reflected in the second part of the Armenian flashback, addressing the survival of Armenian cultural memory and its revival.

The pomegranate brooch, taken by Stamboulian's son Yervant from the desk where he had left it before being deported, will allow for a late re-union between Yervant himself and his sister Shushan. Having formed a family in the United States, Yervant goes back to Turkey in search of his lost sister, who has married a Muslim man, converted to Islam, taken the Muslim name Shermin, and delivered her first child. The brooch is the only way for Shushan to identify her brother: 
Though even the dearest memories of her childhood eventually vanished, the brooch remained vividly ingrained in her mind. And years later when a man from America appeared at her door, it would be this very brooch that helped her to fathom that the stranger was none other than her own brother. (326)

At the same time, it is the only connection left between Shushan and her long forgotten Armenianness, as the following quotations will illustrate:

This new name, religion, nationality, family and self she had acquired had not succeeded in overtaking her true self. The pomegranate brooch whispered her name and it was in Armenian. (328)

Torn between loyalty to her new household and the desire to join her family and community in America, Shushan/Shermin will make up her mind only after contemplating the pomegranate brooch: "As her mind had been reflecting and her heart aching without her knowing it, she ran to the drawer and held the brooch tightly in her palms, feeling its warmth" (328). Thanks to the brooch and the feelings of loss and belonging it resurrects, Shushan/Shermin decides to leave her Muslim household and follow her brother to reunite with her family and people: "Appealing for consolation that no one could give her, she stared at the Pidgeon's Blood. ${ }^{91}$ Only then did she acknowledge what she needed to do." (328)

In the two siblings' reunification, the pomegranate has multiple functions. Firstly, it allows Shushan to identify the stranger from America as her lost brother; secondly, it reminds Shushan of her childhood and, most importantly, of her Armenianness, which she had to suppress for the sake of a new Muslim identity; finally, it is the decisive element convincing her to leave her husband to follow her brother to America.

Similar to the fig tree, pomegranate symbolism transcends the limits of the individual or familial level to define the history of collectivities, as it accompanies the re-aggregation of the Armenian community away from the territories of the Empire. In the Armenian subplot the United States is presented as a space where the Armenian families and community can reconnect.

The United States presents the characteristics of multiculturalism, cosmopolitanism and religious tolerance proper to the multiethnic Ottoman Empire Shafak describes in many of her fictional and non-fictional texts. Consider, for instance, the following lines from an interview with the author:

91 The variety of rubies decorating the brooch go by the name of pigeon's blood (327). 
[Turkey and America] have so many things in common - particularly in societies like Anatolia in the $13^{\text {th }}$ century, where there were people from all kinds of religious backgrounds, all kinds of ethnic backgrounds, and there was an amazing exchange of ideas and, you know, daily habits. To me, this is something precious. (Shafak in Carruthers n.p.)

More examples of Ottoman cosmopolitanism can be found in The Bastard of Istanbul; the nostalgic words of a cook, for instance, evoke the notion of ethnic "intermingling" that characterize Shafak's Ottoman Empire:

"The city was so cosmopolitan once [...]. We had Jewish neighbors, lots of them, we also had Greek neighbors, and Armenian neighbors... As a boy I used to buy fish from a Greek fisherman. My mother's tailor was Armenian. My father's boss was Jewish. You know, we were all intermingled." (170)

The narrator also reveals that Stamboulian strongly believes in Ottoman cosmopolitanism and fears that imperial government is "abandoning Ottomanism for Turkism" (232), that is, replacing an all-encompassing view of citizenship with ethnically based nationalism.

Hovhannes Stamboulian believed that under the present circumstances Ottomanism was the best option for Armenians, not radical ideas. Turks and Greeks and Armenians and Jews had lived together for centuries and still could find a way to coexist under one umbrella [...] "We need to work together. Jews and Christians and Muslims. Centuries and centuries under the same imperial roof. We have been living together all this time, albeit on unequal ground. Now we can make it fair and just for all, transform this empire together." (232)

In short, the Stamboulian family, fragmented by the Armenian genocide of 1915 and the collapse of the Ottoman Empire, is reunited under a new multicultural 'empire' that, in The Bastard of Istanbul as well as in other texts by Elif Shafak, retrieves and develops the ideas of multiethnic symbiosis that could not survive the demise of the Ottoman Empire, the rise of Turkish nationalism, and Atatürk's republic. The Armenian subplot - like the episode involving Aram and the fig tree - especially addresses the relationship between Ottoman Armenians and Armenian diasporic communities living in the United States, suggesting that the Armenian American communities live in a new multicultural space closely resembling the conditions of peaceful coexistence in the Ottoman territories.

This assumption correlates with another symbolic use of the pomegranate, appearing again in the text as a metaphor of the shattering of the Ottoman Empire and the subsequent Armenian diaspora. The parallel emerges from a comment by an Armenian friend of Hovhannes Stamboulian, Kirkor Hagopian, in response to his companion's utopian projections of an Ottomanist future. 
"My friend, wake up, there is no together anymore. Once a pomegranate breaks and all its seeds scatter in different directions, you cannot put it back together." [...] Hovhannes Stamboulian couldn't help seeing that image in his mind's eye: a broken pomegranate, red and sad. $(232,233)$

The image opens a scenario in which the Ottoman Empire and its values of multiculturalism and tolerance have been compromised beyond repair, like a shattered pomegranate. The pomegranate metaphor has yet more implications: the abruptness implied in the act of shattering a pomegranate and the resulting red mash, once again, is a prophecy of violence. Moreover, the "scattering of seeds" mentioned by Kirkor Hagopian anticipates the diaspora which will necessarily follow the disastrous collapse of the empire. The two terms are in fact tightly related: the ancient Greek term for "pomegranate," polyspora (multitude of seeds), shares its root with the term diaspora, meaning precisely 'scattering of seeds' in ancient Greek. The Armenian subplot and the image of a pomegranate brooch serve as a confutation of Kirkor Hagopian's statement on broken empires, as the Stamboulian family will finally, even though not completely, be reunited under a new 'empire.'

The pomegranate brooch physically and symbolically accompanies the eventful history of the Armenian family; from the family idyll in Istanbul, when Hovhannes's pregnant wife is presented with the brooch in the shape of a pomegranate, down to the family tragedy during the Armenian forced relocations, and finally to the 'resurrection' of the Armenian family in the United States. The Stamboulians' family narrative - peaceful life in Istanbul, relocation, genocide, and diasporic existence - transcends the family's private life and exemplifies the collective destiny of the Armenian community in the final years of the Ottoman empire, taking them from an integrated life as Ottoman minority across the 1915 genocide and finally to the diaspora.

As the discussion intended to show, botanic symbolism in The Bastard is dense and multilayered. The fig tree and the pomegranate are two poignant symbols that, being common to various religious traditions, show their interconnectedness and thus highlight the novel's concern with mitigating cultural conflict. Additionally, they synthesize seemingly oppositional meanings such as birth and death, destruction and preservation. The fig tree is a powerful symbol in numerous cultural traditions - the Judaic, the Christian, the Islamic, the Hindu, and the Buddhist - and it appears in connection with the Armenian character Aram. The upturned fig tree Aram imagines is reminiscent of the Țūbā Tree in the Koran but it acquires new meanings if read in the light of Hindu mythology. In any case, Shafak resorts to the upturned fig tree to accentuate the significance 
of Armenian cultural memory and identity in a post-genocidal era and discuss residual postcolonial dynamics in the age of the Turkish republic.

In a similar manner, the pomegranate appears in the chapters dedicated to Ottoman Armenians in the form of a brooch given by Hovhannes Stamboulian to his wife. The pomegranate is also a transcultural, transreligious element that acquires symbolic value in many cultural and religious traditions. In The Bastard of Istanbul, the multifarious symbolism attached to the pomegranate refers to both the fate of an Armenian family and, at the same time, of the Armenian community as a whole. The traditional association of the pomegranate with concepts of maternity and fertility makes the pomegranate brooch an ideal well-wishing gift to a pregnant mother, representing a family idyll and a period when the Armenian community is also described as "pregnant with innovative ideologies and ardent debates" (226). When found in combination with Mary and her child in Christian iconography, the pomegranate symbolizes Mary's fertility and foreshadows the death of Christ. In a similar way, the brooch ominously foreshadows the Armenian genocide and the shattering of the family idyll. If the pomegranate represents the death of Christ on the one hand, on the other it also anticipates his resurrection; similarly, the Armenian family and community are also re-united and re-born in a new environment, the United States. The pomegranate brooch traces the destiny of a family as it unfolds through abundance, death, and rebirth under a new multiethnic society, as well as the history of the Armenian community shortly before, during, and after the 1915 genocide, delineating how their imperial existence came to an end and a new, diasporic one started under a new multicultural empire.

Another interesting aspect of pomegranate symbolism in The Bastard emerges in the comparison between the collapsed Ottoman Empire and a broken pomegranate. The implications of this parallel are manifold, ranging from the realization that Ottoman multiculturalism (as understood by Shafak) was hopelessly compromised, to the prophecy of blood-shedding embedded in the image of a broken pomegranate, and the scattering of seeds that stands for the diasporic existence into which the imperial minorities would be forced. Curiously enough, on a symbolic level the pomegranate brooch confutes the broken pomegranate. The 'seeds' scattered by the fragmentation of the Ottoman empire can indeed be re-united in the United States, a nation that, in Shafak's fiction, presents all the features of multiculturalism, religious tolerance, and linguistic variety that characterized the Ottoman Empire. 


\title{
Birds of Migration: Ornithological Symbolism in The Bastard of Istanbul and The Saint of Incipient Insanities
}

\author{
Birds of migration were the most peculiar of all fowl. \\ Initially, they detached from their own flocks to migrate to faraway lands, \\ and once there, they flocked into detachments. \\ Elif Shafak, The Saint of Incipient Insanities
}

Like trees and plants, birds are important components of natural symbolism in Shafak's novels. Bird symbolism in The Bastard of Istanbul (again in the Armenian subplot) and The Saint of Incipient Insanities does not only cover the history of an ethnic group, but symbolizes two different types of migrants, contributing to shape a dualism that is central in Shafak's fiction. These two different migratory experiences are personified by two couples of opposites: Armanoush and Asya in The Bastard, Gail and Omer in The Saint of Incipient Insanities: Armanoush and Omer are migrants living in a foreign country (an Armenian and a Turk in the United States), whereas Asya and Gail live like foreigners in their own country. It is on this last condition - being foreigners in one's own homeland - that Shafak elaborates most compellingly, as the author herself points out in an interview:

most people lead their lives in their homelands. Some people live the lives of foreigners in foreign lands. And then there are some others, a few others - like Native and African Americans - who lead the life of a foreigner in their own homeland. It is their position that is more difficult to understand. They are the true exiles and expatriates: their bodies seemingly at home, their souls in exile. (Shafak, "Migrations" n.p.)

It is in order to portray this peculiar condition that Shafak makes extensive use of bird symbolism, which takes up a prominent position in both The Bastard of Istanbul and The Saint of Incipient Insanities.

\section{Amnesiac and Memory-Bound Societies: The Bastard of Istanbul}

The first bird symbol appears very early in The Bastard: in the Armenian flashback Hovhannes Stamboulian, the Armenian poet, is working on a children's book entitled The Little Lost Pigeon and the Blissful Country. A collection of Armenian folktales, the book addresses Armenian families, encouraging them to read the tales to their children in order to keep the Armenian cultural tradition alive. The book remains incomplete, as Turkish soldiers arrest Stamboulian before he can finish the last chapter. Stamboulian's anthology acquires great metaphorical significance in the text, connecting to the Armenian question as well as to wider considerations regarding the nature of migration. First, the book 
underscores the importance of handing down collective memory, especially in the case of diasporic communities; second, it reflects on how different peoples - Turks and Armenians in this case - display opposite attitudes towards their cultural memory and their past.

In Das kulturelle Gedächtnis, Jan Assmann proposes that a country's identitybuilding process is closely dependent on the notion of a shared past. Assmann explains that the continuative identity that societies hand down to future generations is built on a culture of remembering: it is the remembering of the past that supports the construction of a communal knowledge and self-image, as well as of the idea of a "We" (Assmann 16-17). Shafak's Turkish and Armenian American communities represent opposite and equally dysfunctional variations on Assmann's theme. On the one hand, Turkey is presented as an amnesiac society, driven by the urge to forget its own pre-republican past. In Shafak's reading, a nation that relies on forgetting for self-definition is dysfunctional in so far as a denial of history is conducive to a denial of the individual, as Asya's pronounced cupio dissolvi shows. The overemphasis on remembering that informs Armenian American identitarian narratives is, to Shafak, equally dysfunctional, as rage and trauma emerge as the strongest factors that determine the Armenian American self-perception. The Turkish and the Armenian (American) communities have coexisted on the same territory and thus inevitably share a past, but the two communities have spun divergent and conflictual historical narratives. Even their conceptualizations of the past are antipodal: a foreign and distant country for the Turkish characters in the novel, a resilient space of belonging for the Armenian American. In The Bastard, bird symbolism is used to shed light on the function of remembering in the Armenian and Armenian American communities.

The protagonist of the frame narrative introducing the different stories in Stamboulian's anthology is a bird:

a pigeon lost up there in the blue skies while flying with his family and friends over a blissful country. The pigeon would stop at numerous villages, towns and cities, searching for his loved ones, and at each stop he would listen to a new story. (226)

The motif of a wandering bird gathering Armenian folktales, "most of which had been transmitted from generation to generation, others long forgotten" (226), emphasizes the importance of cultural memory and foreshadows the idea of the Armenian population as a geographically dispersed community whose stories need to be gathered and preserved by a single agent (the bird, i.e. the writer).

The following developments in the story of the pigeon - who loses his way and then lands on a pomegranate tree - are equally important in terms of the relation they establish with the rest of Shafak's text: 
"Don't cry little pigeon," said the pomegranate tree. "Let me tell you a story, the story of a little lost pigeon."

"But that's me you're talking about. I am that pigeon!" chirped the Little Pigeon in surprise.

"Oh really" asked the pomegranate tree, but didn't sound the least surprised."Then listen to your story... don't you want to learn about your future?"

"Only if it's a happy one," said the Little Lost Pigeon. "I don't want to learn about it if it's sad." (228)

The pigeon's reluctance to hear about his future, fearing that it might be a sad one, alludes to Shafak's understanding of how Turks and Armenians relate to their cultural history, memory, and past. The main assumption put forward by The Bastard of Istanbul, supported by other non-fictional texts by Shafak, is that if Armenians are trapped in the memory of their past, Turks, on the contrary, have managed to erase it and have succumbed to a government-induced collective amnesia. The pigeon episode, stressing the importance of documenting the past with loving devotion as well as the fearful rejection of the future, encapsulates the totalizing relationship between Armenians (in Turkey and abroad) and their memory as it appears in Shafak's novel. The following excerpts, all revolving around the Armenian American co-protagonist Armanoush, explain the prominence of the past in the Armenian American collective memory:

They talked a little, [Matt] about the career he wanted to build, [Armanoush] about the childhood she would like to destroy; he about his future plans, she about the traces of her past; he about his expectations in life, she about family recollections. (108)

Not that [Asya] was hearing the story of the deportation of the Armenians for the first time. But it was quite a different experience to hear an account from an actual person [i.e. Armanoush]. Never before had Asya met someone so young with a memory so old. (165)

"You're fascinated with history."

"And you aren't?" drawled Armanoush, her voice conveying both disbelief and scorn. (179)

The pigeon on the pomegranate tree epitomizes the prominent role memory plays for Armenians and Armenian Americans. It struggles to find his family and friends while gathering Armenians stories, fragments that will reconstruct his cultural memory and tradition, but it reacts uncomfortably when its future is mentioned. For Armenian Americans in The Bastard, the past is the only possible space of identity.

Turkish characters have the opposite approach to history. This is evident in the figure of Asya, the nineteen-year-old Turkish protagonist. Asya seems 
to have no interest either in her individual past or in the history of her country. Her desire to forget is illustrated by her envy for her grandmother's Alzheimer's disease. Creating an enormous distance between the individual and their memory, Alzheimer's holds the promise of an "autonomous realm of amnesia" (128):

"Alzheimer's is not as terrible as it sounds. The past is nothing but a shackle we need to get rid of. Such an excruciating burden. If only I could have no past - you know, if only I could be a nobody, start from point zero and just remain there. Light as a feather. No family, no memories and all that shit." (148)

The following passages - describing a very different viewpoint from that of Armanoush - show how the detachment between the individual and the past not only affects Asya and her personal story (which, with Asya being the 'bastard' in the title, is characterized by a missing father), but the entire community of Turkish citizens. They describe the reaction of Asya's family to Armanoush's account of the Armenian genocide and introduce the idea of the past as a foreign country to the Turks. The first quote refers to Cevriye, one of Asya's aunts and a history teacher, while the second excerpts involves the entire family:

Twenty years in her career as a Turkish national history teacher, and [Cevriye] was so accustomed to drawing an impermeable boundary between the past and the present, distinguishing the Ottoman Empire from the modern Turkish Republic, that she had actually heard the whole story as a grim from a distant country. (164, emphasis added)

The women in the house listened to [Armanoush's] family's story with sincere interest and sorrow but that is as far as they could get. The past is another country for the Turks. (183, emphasis added)

Forced into a diasporic existence, Armenians in The Bastard of Istanbul concentrate on keeping their cultural memory alive in order to foster national unity. By contrast, Turks had to detach themselves from the history of the Ottoman Empire with its calamitous events.

According to Shafak's novel, the reason why the new-born republic had to insist on the separation from the imperial past is, paradoxically, the same reason why Armenians cling to their past: namely, fostering national(ist) unity. This forces Armenians and Turks into two conflictive situations:

[Armanoush], an Armenian, embodied the spirits of her people generations and generations earlier, whereas the average Turk had no such notion of continuity with his or her ancestors. The Armenians and the Turks lived in different time frames. For the Armenians, time was a cycle in which the past incarnated the present and the present birthed the future. For the Turks, time was a multihyphenated line, where the past ended 
at some definite point and the present started anew from scratch, and there was nothing but rupture in between. (165)

This passage echoes Shafak's article "Memory-less Turkey/Amnesiac Turkey" (2006), in which she explains the difference between "amnesiac" societies and "memory-bound" ones. Shafak claims that this difference in perceiving a nation's collective past applies to non-Jewish and Jewish Germans in Germany as well as to Turks:

Societies are distinguished from one another not only by their governmental styles and their economic structures, but also by their relations with the past. Every nationstate rewrites its own history, and does so subjectively. But while some can be called 'amnesiac societies', still others can be called 'memory-bound societies.' ("Memory-less Turkey/Amnesiac Turkey" n.p.)

For some nation-states, the collective-memory of their society is an all-important thing. Some societies take the task of remembering the past as just that: a mission that is incumbent upon them to carry out. For them, it is a citizen's duty to remember the past. But what about in Turkey? The situation here is the exact opposite. With us, the tendency towards forgetting history tends to dominate. Turkey is a society of collective amnesiacs. (ibid.)

Two ideas of migration correspond to these different ways of relating to the past. While Armenian Americans are a diasporic population proper, both Armenians and Turks in Turkey live the life of foreigners in their homeland. Armenians have been deprived of their right to citizenship and suffer discrimination, whereas Turks have fallen prey to a "collective amnesia" that alienates them from their own cultural history. As a result of their denial, it is impossible for them to fully relate to the modern reality of the Turkish republic, deprived of its past and projected towards a Westernized future. The representatives of these two types of migration, in The Bastard of Istanbul, are Asya and Armanoush, respectively representing Turks and Armenian Americans. A similar division appears also in another novel by Elif Shafak, The Saint of Incipient Insanities (2004), where migration and its subdivisions are once again portrayed with the help of bird symbolism.

Appearing but briefly in The Bastard in the figure of the pigeon, bird symbolism is more articulated and diversified in The Saint of Incipient Insanities, and helps a further contextualization of the "Little Lost Pigeon" in The Bastard. Bird symbolism in Elif Shafak's The Saint is mostly related to the issue of migration: the book returns to the theme of 'inland' migration so dear to the author and questions contemporary Othering strategies targeting migrants. "Who is the real stranger," inquires the narrator as the novels nears its end, 
"the one who lives in a foreign land and knows he belongs elsewhere or the one who lives the life of a foreigner in [one's] native land and has no place else to belong?" (The Saint 351). In The Saint, however, the inland migrant is not a Turk in her native Istanbul - like Asya in The Bastard - but an American citizen in the United States.

Birds first appear in the epigraph of The Saint: a poem by Rumi entitled "The Cause of a Bird's Flying and Feeding with a Bird That Is Not of Its Own Kind."92 In this short anecdote, the speaker spots a crow and a stork flying together. Wondering what may have lead the two birds to choose each other as flying companions, he soon realizes they are both lame. The poem includes images of birds isolated by their own flock and anticipates the content and message of the novel. Even chapter titles - "The Crow," 'The Stork," "Birds of Feather," "Destroying your own Plumage" - comment on the opening poem and show the significance of bird imagery in the novel.

In the course of the novel, birds appear in numerous situations. They feature as ancestral spirits ("The crow is the venerated elder of the venerated fowl family. And if you find a crow old enough, the chances are that it might have once looked in the eyes of your great-grandmother," 7); they symbolize a fresh start ("they have stoically agreed to move to a completely empty house, and, once there, make a complete fresh start as light as a feather, ${ }^{\prime 93} 19$, italics in the text); they are mentioned in relation to feminism ("We are feminist magpies stealing old patriarchy's words so that they won't be used against women anymore," 48). Finally, birds in The Saint are celebrated for their putative capacity to 'change names' and, along with names, identities. Multiple names correspond to multiple selves, and to a fluid identity that is not fixed and determined by such markers of identity as ethnicity, social class, and provenance. The novel's protagonist, whose name, at this point, is still Zarpandit, claims to envy birds their multiple identities. To her, leaving one's own flock corresponds to transcending differences and overcoming discrimination:

92 "I saw a crow running about with a stork/ I marveled long and investigated their case,/ In order that I might find the clue/ As to what it was that they had in common.../ When amazed and bewildered, I approached them,/ Then indeed I saw that both of them were lame." The poem - of which Shafak provides the first six lines - is part of Rumi's Mathnawi, Book II. The English translator is not mentioned.

93 The expression "light as a feather" appears in The Bastard in a very similar context, namely. When Asya talks of her necessity of having no past, she says: "If only I could have no past - you know, if only I could be a nobody, start from point zero and just remain there. Light as a feather" (The Bastard 148). 
"I envy birds because of their names. We've only one name, or maybe two. But birds have hundreds of them. Even a single species of fowl has so many different names" (57)

"Change your name and your identity, have no name and no identity. Only if we stop identifying ourselves so much with the identity given to us, only if and when we really accomplish this, can we eliminate all sorts of racism, sexism, nationalism, and fundamentalism, and whatever it is that sets barricades among humanity, dividing us into different flocks and subflocks." (145)

The most eloquent examples for the correspondence between names and identities are the two protagonists. The first is an American woman who changes her name spontaneously from Zarpandit to Gatheride, to Ilena, and finally to Gail, and wears a metaphorical spoon in her hair to remind her that "whatever name she found herself attached to, could be erased and replaced with the letters of another name" by mixing letters as easily as one stirs a soup (70). Her partner is a Turkish student who moved to the United States and Americanized his name by dropping the dieresis, going from Ömer to Omer. By doing so, Omer increases his detachment from his Turkish roots and reveals his desire to reinvent himself. Rather than embracing Omer's desire for assimilation, however, the narrator condemns the practice of Americanizing one's name, common among migrants in the United States, as "getting away from your innermost seed" in order to "becom[e] more visible in the eyes of others" (5). Increased visibility in the host country corresponds, in Shafak's text, to making the country of origins invisible, as the omission of the dieresis proves.

In The Saint, the two protagonists, Omer and Gail, correspond to the Crow and the Stork in Rumi's epigraph: two birds left behind by their own flock and paired by their shared disability, as both, although in different ways, are outsiders existing beyond the borders of the American majority, locating their identity in a state of inbetweenness rather than in their Americanness or Turkishness. If Omer conceals his Turkishness but, although assimilated, will never be fully American, Gail, who was born in the U.S., feels uncomfortable about her nationality. She will eventually grasp the nature of her identity on a journey to Istanbul - a city between two continents - when "it occur[s] to her, and the next second she knew with certainty that this inbetweendom was the right place, and this very moment was the right time to die" (347). By committing suicide on the Bosphorus Bridge, Gail fixes her identity in a suspended space in between continents and exposes the obsoleteness of national belonging.

The Saint mostly focuses on stories of migrants in the United States (including international students), who, according to the narrator, tend to identify fellow citizens from their country of origins and re-aggregate in small national 
clusters. The narrator explains this behavior through an ornithological metaphor: "birds of migration were the most peculiar of all fowl. Initially, they detached from their own flocks to migrate to faraway lands, and once there, they flocked into detachments" (81). Parallels between migratory birds and migrant communities recur frequently in The Saint of Incipient Insanities and The Bastard of Istanbul. The two texts bring forward one image in particular, that of birds left behind by their own flock, which dominates the discussion of identity, belonging and migration.

The little pigeon in The Bastard of Istanbul, collecting Armenian tales in Hovhannes Stamboulian's children's book, can be read as a member of a community in a process of diaspora and its story stresses the importance of preserving cultural memory. In addition to that, it embodies the difference between the Armenian and the Turkish attitudes towards the past. The eagerness of the pigeon to collect stories from the Armenian past, and his reluctance to hear about his future from the pomegranate tree, alludes to the position of the Armenians towards their cultural past, as depicted in this text.

In The Saint of Incipient Insanities the two protagonists, Omer and Gail, display fluctuating identities that position them outside the boundaries of the American majority. The novel is built around the bond between naming and identity: identifying with one given name means embracing the limits of the identity one was born with, while switching between multiple names corresponds to inhabiting the interstitial spaces between the traditional categories of belonging such as nation, gender, or sexual orientation. In the text, birds figure as metaphors of this fluid condition. The crow and the stork, being lame, have been abandoned by their flocks: their story is the story of Gail and Omer, who, in spite of their different nationalities, have been brought together by their flexible, unstable identities. In The Bastard, the pigeon losing track of its flock is Shushan, who is separated from her family during the genocide and remains in Turkey, while many Armenians, including her brother, emigrate to the United States. In one way or another, all these 'birds of migration' - Shushan, Armanoush, Omer, and Gail - seek to participate in or escape from Americanness. Shushan and Armanoush, as Armenian Americans, will be re-joined with their dispersed national community in the United States, while Omer and Gail struggle to partake in the American mainstream. 


\title{
The End of the Ottoman Garden: Alev Lytle Croutier's Seven Houses
}

\author{
Some plants disconnected easily but others resisted, \\ leaving them no choice but to twist and pull, mangling the break. \\ It was violent. Each time they could hear the flowers cry, \\ they could sense the breaking of their own heart. \\ Alev Lytle Croutier, Seven Houses
}

\section{Space and Narrative in Seven Houses}

Identity is shaped by space, and changes in landscape correspond to changes in a community's self-perception. This process has been extensively addressed in the field of Turkish studies, given the change that affected the Turkish urban landscape from the end of the $19^{\text {th }}$ century onwards, due to the Westernization policies implemented by the imperial administration in the Tanzimat period and continued later by the republican one. Various studies focus on Istanbul as a living literary scenario or a character proper (e.g. Mallory Katherine Koci's 2009 book Istanbul: Redefining Topoi and Establishing the City as a Character in Contemporary Turkish Novels); others look at how Istanbul's evolving architecture reflected the mutating psychology and concerns of its inhabitants (see Amy Mills' work on landscape and cultural identity/memory in Istanbul); others parallel the Ottoman house structure to the set of values characterizing the Ottoman imperial ideology (Maurice Cerasi's "The formation of Ottoman House Types: A Comparative Study in Interaction with Neighboring Cultures"). These studies highlight the bond between the Turkish population on the one hand and the domestic as well as urban spaces they inhabit on the other. In addition, they hypothesize a deeper bond between the rapidly evolving Turkish cityscapes and the problematic shaping of Turkey's modern, national identity.

Croutier's family saga Seven Houses (2002), spanning Turkey and America, provides a fictional exploration of these identitarian spaces. Each of the book's seven chapters is narrated by one of the seven houses the İpekçi family lived in. Every chapter is preceded by a photograph of the 'narrating house,' and by dates indicating the period of time in which the family has resided there. If, to put it with Maurice Cerasi, Ottoman houses can be considered an "epiphany of the Ottoman civilization" (Cerasi 132), similarly representative values can be attached to the apartment buildings that spread due to the rapid urbanization that swept Turkey (Istanbul in particular) from the beginning of the $20^{\text {th }}$ century onward. By then, Western architecture had stopped being merely one component of the 
Ottoman plethora of architectural influences, but became its most prominent feature. In "Democracy, Development and the Americanization of Turkish Architectural Culture in the 1950s" (2008), Sibel Bozdoğan addresses the "internationalization" of Turkish architectural culture in the 1950s, equating it with Americanization (Bozdoğan 117). According to Bozdoğan, Turkish architects in the Fifties "abandoned the search for a 'Turkish national style' and [...], with a new sense of belonging to an international community of modern nations, they embraced a new supranational aesthetics of bureaucratic efficiency (as best symbolized by the recently completed U.N. building in New York)" (Bozdoğan 119).

Croutier's effort is precisely that of using architecture to comment on the mutation of Turkish culture in the passage between the empire and the republic and in the decades to follow. Gardens are essential in the shaping - and, remarkably, in the losing - of Turkish identity in the crossfire of Americanization and Ottoman nostalgia, Islamic tradition and secularism, continuity and historical amnesia. In Seven Houses, gardens function as filters, metaphors, and victims of the massive, turn-of-the-century metamorphosis of Turkish society.

In the novel one family matriarch (Maria) and one patriarch (Iskender) are trapped in the passage from a slow, timeless Ottoman universe to the republic's fast materialism: neither they nor the gardens they live in will survive this change. In fact, in the secular republic of Turkey, little room is left for these ancient figures and for their gardens, mysterious remnants of Ottoman magic and folklore that the new Turkish society observes with a mixture of compassion and indifference. The two gardens - almost symbolic representations of their owners' souls - are portrayed as loci of Ottoman nostalgia, as mystic paradises, and as utopian strongholds where the Turkish folkloric tradition flourishes and prospers. Remarkably, one is destroyed in a fire and the other is torn down to make room for a road enlargement.

The demise of these two oases of tradition and their elderly keepers parallels the erasure of Turkey's Ottoman legacy, and to the ensuing replacement of the old imperial mindset with new Westernized values. The significance of gardens must therefore be examined in the light of massive urbanization and Westernization, whose voiceless symbolic victim they represent. This scenario is complicated, firstly, by the use of Orientalist clichés in the description of the two gardens, and secondly, by the attitude of acceptance displayed by the family members and the matriarch herself vis-á-vis the devastation of their cultural landscape. My intention is not only to show how gardens in Seven Houses embody the relationship between republican Turkey and its imperial, Islamic past. I also claim that through the use of Orientalism and the resigned acceptance with which the 
characters witness the destruction of their Ottoman gardens, Seven Houses expresses an ambivalent attitude towards the early republican Westernization project, one that is perched between accusation and the awareness of its necessity. Seven Houses, therefore, does not oppose Kemalism as vehemently as Shafak's novels, which unambiguously condemn Kemalist reforms.

\section{The Patriarch's Garden}

Alas, Iskender Bey's fortune melted like a candle. Too much of an old silkworm to make the adjustments to a chameleon world that had left him behind in an oasis of loneliness he, in turn, had abandoned the world that could not remember its past nor recognize its own reflection in the mirror. No one ever mentioned the fire that had killed Iskender Bey and devastated the plantation. (Seven Houses 119)

Referring to the destruction of Iskender Bey's silk plantation after its bankruptcy, this citation is a significant one for two reasons. Firstly, it illustrates that the disappearance of the patriarch's "fortune" was due to the transformation of Turkish society in the first years of the republic until the Fifties, the time period in which the story of Iskender's plantation takes place. The decades from 1930 to $1959 \mathrm{can}$ indeed be identified as the period when the country's dominant ideology, insisting on rapid Westernization and modernization, was put into practice. The quote highlights the contrast between a country rapidly evolving towards standards of Western modernity on the one hand and the patriarch's old-fashioned silk plantation on the other. The incapability of the elderly man - the "old silkworm" - to "adjust" to Turkey's modernity is offered as the reason of his demise.

Secondly, the idea that Turkey "could not remember its past or recognize its own reflection in the mirror" is reminiscent of Shafak's image of the past as a foreign country in The Bastard. Such similarity between Shafak's and Croutier's representations of the past indicate the presence of a recurring narrative in Turkish American literature imagining modern Turkey as alienated from its history and incapable of self-representation ("could not [...] recognize its own reflection in the mirror"), due to the rupture with the Ottoman imperial legacy and the consequent mutation in the nation's self-perception.

I argue that the fate of the patriarch's plantation is intertwined with the social and architectural changes that connoted the first decades of the Turkish republic: it exemplifies the painful passage from an imperial universe to a national one and emerges as the arena in which Ottoman nostalgia and acceptance of a Westernized future are negotiated. To the eyes of a Turkish child called Amber, Iskender Bey's niece, the plantation is a paradise, an enchanted world populated by supernatural beings, an extended family garden where Islamic folklore resiliently 
resists the widespread modernization. The plantation becomes the theater of the exclusive friendship between the family patriarch and the child, which develops in the depths of the plantation. The child sees it as an extended playground, a safe place presided by the godlike figure of the patriarch - "an old wizard, see all, know all, as fierce as the God who had ordered Abraham to sacrifice his son" (105). But for Amber the plantation is much more than a garden, it is a universe of storytelling and communion with nature:

Iskender told the story of every tree and stone, reinventing everything on the spur of the moment, spinning stories until they became completely ludicrous but still credible [...]. He told her stories of the Silk Road, of places where people were yellow, where they ate monkeys. Of giant ants guarded by griffins digging up the earth for gold, of pearl divers who found treasures buried beneath the sea in dark sinister caves, of skinny naked men sitting on beds of nails, of people who lived hundreds of years because they drank from a special spring, of giants and unicorns, lions and tigers, jewels scattered everywhere like dust, the cobras that guarded them, and of perfumes and silk that grew on trees. (100)

The imaginary universe Iskender discloses to the child and that becomes associated with the plantation contains an array of Orientalist tropes. Islamic folklore is coalesced with the Western Orientalist tradition, as Herodotus' giant ants prove. ${ }^{94}$

Once Amber re-emerges from the plantation, she is, however, confronted with her mother Camilla's skepticism:

"I saw a chameleon that changed into the color of purple hyacinths, I even saw a camel being born [...]. Uncle Iskender said I can have it."

"He’s lost his marbles," Camilla said, exasperated. "Senile old creature. He knows it's ridiculous. He knows camels are not allowed in modern cities!"

[...]

"Can't you see the fire in [Iskender's] eyes when he looks at Amber? We have to separate them [...]. It's unsavory." (103)

Besides criticizing the unusual intimacy between Amber and Iskender, fearing that his interest for the child may go beyond filial affection, Camilla is dismissive of the kind of knowledge that the old man is handing down to Amber. The prospect of her child being initiated to Ottoman folklore makes Camilla uncomfortable, and, by dismissing Iskender's stories as irrational, she mimics the Kemalist posture towards the Ottoman heritage. Iskender's "senile" fantasies have little to do with the trajectory of Westernization that the young Turkish generations will have to follow. By stressing the fact that camels are not allowed in "modern cities," Amber's

94 The reference to gold-digging ants can be found in Book II of Herodotus' Histories, where the Greek historian describes the culture of India. 
mother re-enacts the rupture between Turkey's 'Eastern' tradition (condensed in the Orientalist cliché of the camel) and modernity, between the enchanted plantation and Istanbul's metropolitan ambitions. Amber eventually identifies Iskender's silk plantation with an "oasis" (119) where a folkloric Ottoman past is safeguarded from outside events, a semi-divine paradise untouched by raging Westernization, heavily romanticized through childlike imagination and sublimated by the luxurious Orientalist descriptions that contribute to the place's enchantment.

More gardens are lost along with the devastation of Iskender's plantation, sold by the family's new patriarch, a man named Cadri, in order to pay for the family's debts: "The summer yali in Moda, the fig orchards along the Aegean, the hunting lodge in the Belgrad forest, the villa in Pamukkale Hot Springs, the vineyards" (120). Caught at the crossroads between the imperial past, represented by the İpekçi's aristocratic gardens, and the republican future, the new patriarch embraces the country's new mindset and moves the family to Ankara, described by the narrator as a city that sprang out of Atatürk's imagination:

Ankara, a dusty city in the arid Anatolian plains, the ancient Angora. [...], a nomadic inland rumbling with blood memories of human sacrifices for rain, a modern city reborn out of a need to find fulcrum for the revolution, a city of new beginnings that Atatürk had elevated overnight to the status of the new Turkish Republic's capital. (120) ${ }^{95}$

The İpekçis' plan to become part of the new Turkish nationalist dream and relinquish their aristocratic past is completed when the family moves to one of the concrete apartment houses that function as metonymy for frenzied urbanization. The narrator describes them as standing "in a grand row, all more or less identical, cement colored, six stores each - mutant progenies of urban functionalism, ghostless and hollow inside" (121). A product of modernization, Ankara finalizes the rupture between the İpekçis and the territory they had inhabited thus far. The new "ghostless" apartment house contrasts the enchanted wilderness of Iskender's silk plantation, populated by all kinds of Ottoman ghosts.

The disappearance of gardens from the family's life, due to the sudden change in the country's architectural and housing standards at the beginning of the $20^{\text {th }}$

95 This movement from leafy mansions to urban Ankara, as well as the systematic loss of Ottoman nature, are reminiscent of the American frontier. The narrative has been applied before to early republican Turkey by Ernest Wolf-Gazo, who, in his study on John Dewey's "Report and Recommendation upon Turkish Education," claims that Dewey "saw an analogy between the [...] [American] Old West and Anatolia" and saw Turks as the "frontiersmen and women of a newly established land, possessing a vision clearly focused on the future, not on the past. In Ankara he felt the pulse of a pioneer spirit" (Wolf-Gazo in Raw 87). 
century, is indicated by another small detail. If on the one hand the house on the plantation had a hamam decorated entirely with "tiles of birds, of flowers, and an enormous tree of life" (85), the bathroom in the new apartment has "linoleum tiles. No tulips. No tree of life" (124). This architectural change has direct consequences on Turkish culture, as the loss of Ottoman botanic symbolism entails a loss of Ottoman cultural practices. In the new apartments, for example, "communal bathing" and its "respiratory bliss" are irretrievably lost (124), marking profound changes that affect all aspects of life, from bathing down to breathing.

The understandable pain accompanying the family's translocation to another city coexists side by side with a hopeful curiosity for the new, modern existence the family will adapt to. America plays a crucial role in determining such attitude:

America insinuated further into their lives, seducing the women with Frigidaire and Hoover. It also brought along the virus of Time and virus of time, the imaginary. The first item on time: a Miele washing machine for Camilla, with a pot belly and a revolving wringer to feed through. [...] All the women spent months neglecting other tasks to use Camilla's Miele, mesmerized by its rhapsodic churning, exhilarated by the joys of automatism. (123)

Thus, the exoticist, romantic mode that dominated Iskender's plantation and the sentimental farewell to the universe of values it represented are soon replaced by renewed excitement, and by a consumerist frenzy directly connected with the country's Americanization. Benton Jay Komins sees the openness to American commodities as another sign of the rupture with the Ottoman mindset. "Global commodities - especially their promises of a comfortable and modern life - have supplanted understandings of what it used to mean to be cosmopolitan. [...] These commodities, from plastic card tables to internet-ready pocket phones, present an empty form of cosmopolitanism that is disconnected from the pluralism and multicultural possibilities of [Istanbul's] past" (Komins 364). Komins draws a line between the idea of globalization, which he uses almost interchangeably with Americanization, and the idea of Ottoman multiculturalism. He critically hints at the fact that the former has practically supplanted the latter.

\section{The Matriarch's Garden}

Amber opened the wooden gate into a garden entrance with an energetic riot of plants. The creepers strangled the sunlight; the bell-shaped blossoms of trumpet vines, morning glory, and hibiscus dangled from their limp stems [...]. Amber touched her nose, locking the scent in her nostrils so the intoxication would linger. She reveled in her gratitude to the deities for creating such whiteness, the nobility of the soul who placed beauty at the entrance of this humble sanctuary. (268) 
The story of Maria's garden, in the way it develops and in its significance, is comparable to that of Iskender Bey's plantation. Maria is Amber's Greek grandmother, she lives alone in a cottage with a luxurious garden in Izmir; at the center of the garden there is an old well where the spirit of Maria's deceased husband resides. Yet, the cottage and the garden will soon be razed by the city's administration in order to make room for a road enlargement. The destruction of a garden is therefore once again at the center of a discussion on the clash between Turkey's imperial memory and its enchanted spaces (the garden) and modernized future (the road being enlarged).

In the chapter that narrates the last days of the cottage before its destruction, Amber and her daughter, Nellie, take it upon themselves to inform Maria about the eviction and the fate awaiting her home. Like Iskender, Maria is a mystical figure that can be completely understood and envisioned only in relation to her garden: "Even in her long dress and scarf, Maria blended into the landscape, imitating its colors like a chameleon" (270), later on she is said to resemble "some small animal, a squirrel or a rabbit" (272). Like Iskender, the matriarch is godlike, as the mythical space she has inhabited so far mutated her humanity into something more complex: Maria's decrepit appearance encompasses an entire universe of mythological creatures: "Her features began to quiver, subtle changes of skin-deep colors flashed a thousand faces at Amber. Ape women, witches, demented old hags, voluptuous sirens, female Buddhas, antediluvian crones, queens, baby girls, virgins, strange animals, prehistoric female deities, and all else in between" (271). In addition, the garden, in harmony with the supernatural figure of its keeper, is a space where inexplicable events take place: things materialize on tables and the phantom of Maria's late husband appears at night. Similar to Iskender's plantation, Maria's garden is heavily exoticized and eroticized, as the next passage exemplifies:

A flock of hummingbirds, hundreds maybe, were ravaging the flowers in a flutter of erotic madness as if in an esoteric mating dance - now chasing each other, now competing for the orifice of a flower, now swooping so low they almost got tangled in the women's hair. (272)

Both gardens function as oases where Ottoman culture is preserved and sheltered and bear an important link to the empire's history. If the plantation encloses the history of an Ottoman aristocratic family, the cottage is associated with the history of the Greek minority in the Ottoman Empire. In a lengthy account about her childhood, Camilla connects the cottage to the collective memory of the Ottoman Greek minority, highlighting some key elements of their history: 
"I was merely a baby when my father disappeared into the Liberation War, leaving nothing to his wife except a gold watch. My mother, Maria, who'd change her name to Malika and converted from Greek Orthodoxy to Islam to please her husband, sought refuge at her mother's in Bornova, the lovely tree-lined suburb of Smyrna, an oasis for the European aristocracy." (258)

Not only does Camilla connect the cottage to the necessity for Maria to change her name and convert to Islam, but she also points out the importance of the city of Izmir/Smyrna in the family's and the country's history, due to the great fire that destroyed the Armenian and the Greek neighborhoods in 1922. The word "oasis" appears in reference to both Iskender's plantation and the neighborhood where Maria's cottage was located, and it is essential to understand the way gardens function in the novel. These spaces are clearly indicated as an anomaly, an exception in Kemalist Turkey (especially considering the republic's new capital, raised in a symbolically dusty, nomadic inland). Both the plantation and the garden are connoted as safe havens where the Ottoman universe, with its Islamic folkloric narratives, lives on untouched by outer events, immune to the changes occurring in Turkish society and history and yet very short-lived, as both gardens are captured by the novel on the verge of their inevitable destruction.

Maria develops a quasi-mystical relationship with her cottage. In the first family house she shared with her husband, Hamid Bey, Maria retrieves a connection with her 'forgotten', cosmopolitan, multilingual past:

rising as a somnambulist in the middle of the night, [Maria/Malika] would descend down to the basement where earlier Hamid Bey and his Sufi friends had gathered to sing and dance until their feet left the ground and floated like angels in their long white robes and conical hats. Malika sat in candlelight communing with the unseen that the men had agitated, watching otherwise invisible visions from her forgotten past. Sometimes she recited things aloud or hummed in Italian or Greek. (166)

In the solitude of the basement, Maria reconnects with the Greek identity she was forced to erase after marrying into a Muslim family. ${ }^{96}$ There is no trace in the novel of the "distaste for underground structures" that Maurice Cerasi defines as typical of Turkish culture (Cerasi 132). Seven Houses contrasts this assumption by creating densely spiritual underground structures. Another example for this are domestic wells, which are a fundamental architectural feature of numerous

96 Interestingly enough, the "unseen" these men agitate is compatible with Maria's Orthodox Christian spirituality. The intertwining of religious traditions - the Sufi and the Greek Orthodox - underscores the Ottoman tradition of peaceful coexistence and, once again, positions Sufism at the center of a discourse about interreligious dialogue. 
Turkish gardens. The well in Maria's family house appears as a dangerous place children should be kept away from, the reason for this is to be found somewhere between the real danger of falling and drowning and the universe of Islamic children's tales and legends depicting wells as the residence of spirits. Camilla tries to keep Amber from playing near the well:

"Cats have fallen in. Snakes squirm at the bottom. Odjus live inside and when they see children staring at them, they open their mouths real wide and suck them in like marrow," [Camilla] told [Amber], making a sucking and slurping sound. (165)

Unconcerned by the reputation of wells, Maria shows a peculiar attraction to them, as she habitually leans over them, stares inside, and whispers. In the case of the first family well, this behavior is left unexplained. One can assume that, considering Maria's use of underground structures as spaces where she reconnects with her past, like in the case of the basement, the well might give Maria the illusion that she could retrieve her forgotten past: by no means vanished but stored underground.

The cottage well in Smyrna is where the ghost of her husband, killed in the war, came back to reside. Not only does the ghost inhabit the well, but he also takes the bowl of food Maria leaves for him in the garden and leaves a coin in return. This, as Maria explains in the text, not only happens to her, but to other women whose husbands died in the war, as if the deceased men were continuing a traditional family life by accepting the food cooked for them and by financially providing for their wives in return. Therefore, wells appear as places where an irretrievable past is stored, where the matriarch can continue to relate to her repressed Greek ethnicity and with the memory of her family life, as both are not utterly lost, but merely stored away, kept safe, and sheltered. The demolition of Maria's garden and well by the city's administration in order to enlarge a road coincides with the demise of one more imperial family narrative and of an entire world of Ottoman tradition and folklore. At first, the matriarch rejects the idea of leaving a place that is physically populated by her memories, but eventually she agrees to move in with her daughter and abandons the cottage to its unavoidable fate. Once again gardens are left behind with a feeling of acceptance and resignation: in Marias case, her attitude of acceptance is dramatized by the decision to destroy the garden herself before the bulldozers get to it and arrange to cut down flowers as a sacrificial offering.

Maria's conscious decision not only affects the plants, but the birds as well. After the destruction of the Ottoman garden, the hummingbirds, which had infused the garden with erotic madness, are now depicted while desperately searching the devastated bushes for the nourishment that had "fed generations 
of their species" (285), but they eventually lose hope and die from exhaustion. The hummingbirds' last visit to the garden is rendered by the narrator with a very fatalistic attitude:

they were sensing that the plant would no longer bear flowers, and nothing else of sweetness was left in the garden. They were sensing that they had lost their fountain of life and could never return. Their livelihood was gone. (285)

The departure of the hummingbirds marks the end of an entire bird community. The strong exoticism characterizing the first apparition of the birds - coming "in a flutter of erotic madness as if in an esoteric mating dance" (272) - is therefore also bound to disappear and make room for the republic's rationalism.

In Seven Houses, the disappearance of a garden is once again paralleled to the disappearance of the legacy of the Ottoman Empire and its ghosts, supernatural beings, aristocracy, cultural diversity, and orthodox and heterodox spiritualities incarnated by the Sufi Hamid Bey and his wife Maria/Malika, the matriarch. Similar to Iskender Bey's garden, the matriarch's garden also presents exoticized elements, sublimated in the image of the hummingbirds, as it was by the camel in the plantation: both remnants of a surpassed Ottomanness with no hope of survival in "modern cities." The departure of the hummingbirds manifests the surpassing of the concept of Turkey as Orient, erased by the Turkish republic's new Western and secular outlook.

The demolition of Maria's house corresponds to the erasure not only of the physical traces of the empire, but also of its values - above all, Ottoman cosmopolitanism. As a Muslim convert of Greek origins and a lonesome old widow, Maria lacks the power to lay a claim to the land she inhabits and the house she owns. Cengiz Çandar claims that the Kemalist elites, intentioned to create a Turkish national consciousness, "denied the existence of the many non-Turkish ethnic identities within Turkey" (89). Land expropriation ensued as one of the expressions of this denial. To put it with Ariella Azoulay (who explores the significance of house demolition in the colonial context of the Palestinian territories in "When a Demolished House Becomes a Public Square"), due to her ethnicity Maria has entered a condition of "unprotected exposure to power" (205). The presence in one political territory of dispossessed, refugees, and, especially in the case of Turkey, minorities, "does not serve as a condition for their entry into public space, nor does it entitle them to a place within the body politic" (ibid.). On a discursive level, former imperial minorities are not invited to partake in the act of imagining Turkey's post-imperial future, as they do not fit the ethnicist principles on which Kemalist Turkey has built its identity; in the same way their homes "[do] not pose a physical or symbolic obstacle in the way of 
rampantly violent governmental force. [They are] perceived as a spatial disruption of the movement of the governmental force" (Azoulay 205) and therefore lose their "sanctity as a human dwelling and [are] designated for demolition" (210). The expropriation of Maria's cottage indicates that the shrinking of the political space of minorities in Turkey after 1923 was accompanied by a much more tangible shrinking of the physical spaces allotted to them on the republic's territory. The erosion of Ottoman cosmopolitanism as a central component of the imperial society is the obvious consequence of these joint phenomena. To put it with Azoulay, "against the backdrop of the forms of life that existed here, the destruction [...] became in fact an end in itself - destruction of the mixed society that had developed here, and the removal of anything that might enable its resurrection" (214, italics in the original).

The gap between the universe of the matriarch in her garden and the modern world is stressed by scenes of incompatibility between Maria's old traditional ways and Amber's, but especially Nellie's, Americanized attitudes. Amber and her daughter Nellie are first- and second-generation Turkish Americans respectively, and are the youngest members of the family, the last generations of the saga.

"Hello Anne-Anne-Anne," Nellie flirted. Anne is mother. Two Annes grandmother, three grand-grandmother. That she knew from her 'Turkish for Travelers' guide. She took a Polaroid of the birds, gave it to Maria. Maria looked at the picture, trying to make sense of a strange sortilege.

"Take one of the two of us," Amber said while putting her arm around Maria, and her cheek against hers. [...]

Maria cringed when she heard the shutter click, afraid of having her soul stolen. And it was. (273)

Americanization appears in this chapter as a fundamental element of modernity caught in a painful, clumsy coexistence with the old, Ottoman world order. The passage comments on the apparent incompatibility between Ottomanness and Americanness, suggesting serious communication problems between three generations of Turks. The flirtatious behavior Nellie displays with her great-grandmother betrays an incomplete understanding of the matriarch's grief, stature, and dignity, being Maria an heir to the Ottoman culture and the embodiment of its dignified decadence. Nellie's physical warmth and language experiments, stimulating her own amusement rather than attempting to engage Maria in a real conversation, suggest that Nellie, occasionally travelling to Turkey with her mother, aims to be nothing more than a traveler in the land of her ancestors. Her Turkish American great-granddaughter's unrequested attention proves physically overwhelming for Maria, who, on her part, fails to comprehend her relatives' expansiveness. 
The moment the photograph is taken is particularly problematic. Maria tries to relate Nellie's Polaroid to her own cultural universe, identifying it as "a strange sortilege," but "cringes" as a picture of hers is taken. By confirming Maria's fear of "having her soul stolen," the narrator suggests that tradition and modernity, in Maria's garden as well as in the new Turkish republic, are mutually exclusive. The novel points at a fundamental incompatibility between the photograph "the fine child of the age of mechanical reproduction" (Anderson 204) - and the decrepitude of the garden, between the sacredness of ruins and the lack of understanding thereof by the agents of modernity, between irreparable loss and the logics of "infinite reproducibility" and "print-capitalism" (Anderson 182). The fascination with American symbols and consumerism - the household appliances first, now the Polaroid camera - contributes to the erasure of Turkey's traditional past. In fact, the photograph objectifies the matriarch and her garden, reducing them to a portable souvenir of a vanishing world. Benedict Anderson equates photographic reproducibility to profanation and connects these dichotomies to the colonial condition. To Anderson, the photographic gesture repositions monuments and ruins as "regalia" for a (neo)colonial state that does not comprehend the sacredness of the colony's past (182). "Infinite reproducibility," Anderson argues, "[was] made technically possible by print and photography, but politicoculturally by the disbelief of the rulers themselves in the real sacredness of local sites" (ibid.). In Seven Houses, the Kemalist erasure of enchanted Ottoman ruins is coalesced with the specter of Americanization and its imported logics, condensed in the Polaroid camera and the photographic urgency. Both Kemalism and Americanization share important features with colonization processes as described by Anderson: both prove oblivious of the garden's sacredness, the former simply hoping to erase it, the latter eager to commodify it.

Maria's fear of "having her soul stolen" provides a powerful link to the American cultural context, as this belief is widespread among Native American populations as well. Reports by Native American interviewees in Lucy Lippard's essay "Independent Identities" show that Native tribes felt a comparable fear of photographs:

"Some native people believed that with each photograph their soul would weaken [...] the loss they sensed was very real and generations later is still felt by Native Americans today." [...] "Before the picture," says Oren Lyons (Onondaga) "the subject was free and unencumbered. After the picture, the photographer had indeed captured the identity of the person - his or her face." (Lippard 142) 
Lippard also signals that photography can be understood as a marker of an epochal shift, the sign of a new world taking over the old. To Lippard, the cultural opponent to photography is storytelling. "North American society is becoming increasingly dependent on photography and its cinematic, videographic, and electronic offspring. Yet the ancient stories are being replaced by pictures; family albums replaced oral histories" (ibid.). By enabling a connection between Turkish and Native American folklore, the image of the soul-stealing Polaroid resonates strongly in an American context. One can also argue that the Ottoman legacy in Turkey and Native American beliefs in the United States underwent similar Othering processes. This allows American readers to position the relationship between 'modernity' and Ottoman folklore in Turkey with respect to their own history of Othering, disavowal, and repression.

\section{Re-Orientalism, Hyper-Orientalism, and Acceptance: Problematizing Gardens in Seven Houses}

The muezzin's voice rose in the air. The nightingale sang a song of acceptance. A bus went by.

The old woman was vacant. A grayness emanating out of her body, the color of resignation.

Alev Lytle Croutier, Seven Houses

The ostensibly Orientalist portrayal of gardens and the attitude of acceptance displayed by the Turkish characters while witnessing the dissolution of their estates can be analyzed in the light of the search for Turkey's modern national identity. In the novel, Orientalist tropes are employed to describe spaces that are secluded from the outer world where Ottoman tradition and folklore have been preserved throughout the first decades of the Turkish republic, unaffected by the Westernizing and modernizing effort that swept the republic in those same years. Orientalism and the idea of seclusion facilitate a reading of gardens in Seven Houses as sources of untainted Ottomanism. The garden is thus romanticized and turned into a space of Ottoman authenticity: an un-Westernized, un-urbanized landscape featured by the yet uncompromised union of man, nature, and God. The garden associates Ottoman identity with Edenic characteristics, and, according to the Edenic narrative, foreshadows an impending crisis. The use of Orientalist elements in the description of this Eden of Ottomanism is essential to characterize gardens as abstractions, surreal spaces perched between reality and legend, and points at the impossibility of their survival in the quickly evolving Turkish present. The end of these Ottoman gardens, inhabited by ancient patriarchs and 
matriarchs, is presented in the novel as an unfortunate development, and yet an acceptable one, part of the natural order of things.

The İpekçis settle rather cheerfully in their new apartment, ready to start anew:

"Luckily a handful of remaining liras will make it possible to build an apartment complex for all of us to share, right here where your feet are touching the ground, to start a new life here in Ankara where opportunities are greater, where better schools exist for children, and better jobs for men, everything is new and modern in this city. Everything sanitary. Every sign of progress exists." (121)

The matriarch Maria, instead, switches from a loving determination to stay at her house, driven by the attachment to her garden and to the spirit of her dead husband residing in the well, to a pragmatic, matter-of-factly resolution to move to her daughter's house:

"Look at that jasmine bush, look at the bougainvillea [...]. Tell me the truth, do you see them like this anywhere else? No, child. I'm not going to leave my home and go live with my daughter." (282)

"It's all dirt in the end anyway. What does it matter? No. I don't want to be left behind. Tell her, tell Camilla, I'll come live with her. He [the ghost of Maria's late husband] can find me there if he wants to. If he's a spirit, he can go anywhere. My life is spent waiting for him." (284)

The prospect of a new future makes the loss of the Ottoman past bearable. Patriarchs and matriarchs step aside, vanishing or docilely following their world-wise grandchildren into an Americanized existence.

The attitude of resignation that permeates the novel resonates with a statement by the author herself: "In the $20^{\text {th }}$ century's process of modernization," Croutier told Publishers Weekly, "we turned away from the cultural patrimony of the empire. It was necessary because if we glorified the empire, it would have prevented progress" (Croutier in Rosen 63). Similar to Croutier's approval of modernization, the narrative that emerges from the novel is apparently supportive of the Kemalist mindset: the legacy of the empire, if not ejected from the national self, would have prevented the country's modernization. To put it with Welat Zeidanlığlu, the Kemalist discourse constructed Ottoman society as "lacking," as a "source of instability and a barrier to progress," or, more drastically, as an element that would "cause defeat" (Zeidanlıoğlu 159). The novel's Orientalist outlook on Ottoman society is therefore rooted in the Kemalist doctrine. Zeidanlıoğlu, via James Carrier, explains that Orientalism not only serves to draw a line between Western and Eastern cultures, but also "a line within" (Carrier in Zeidanlıoğlu 156). In a Turkish context, this amounts to disconnecting the republican from the prerepublican past. The Ottoman Empire and its legacy thus became the victims 
of what Louisa Schein calls "domestic othering"97 (Schein 73), as the Kemalists sought to rid the nation of its "Orientalness" (Zeidanlıoğlu 159).

This phenomenon can be addressed in the light of Lisa Lau's notion of reOrientalism. ${ }^{98}$ Lau defines re-Orientalism as a "process of Orientalism by Orientals," tice, but one that has been taken up by cultural producers who "derive both ancestry and identity from the Orient" (Lau, "Re-Orientalism" 572). In other words, re-Orientalism theory focuses on 'Orientals' employing Orientalist modes of descriptions in their self-representation, not being Othered by Western observers, but by a "process of self-Othering" (Lau, "Introducing Re-Orientalism: A New Manifestation" 4). As much as the power of representation is now in the hands of these non-Western cultural producers, and no longer in those of Western interpreters of Eastern cultures, the resulting representation remains "filtered through Western lenses [...] with Western frames of discourse, and via Western knowledge systems" (Lau, "Introducing Re-Orientalism: Theory and Discourse" 5). This is particularly true if re-Orientalist texts are designed for Anglophone readers and markets, as they thereby attest the centrality of the West and show their intrinsic ambivalence, circulating "discourse which speaks as much to the West as for the East" (4). According to Lau, however, what differentiates re-Orientalism from Orientalism is not only the origin of the cultural producers, but also the fact that re-Orientalism "is not pitting the 'West' against the 'East', but strives for a much more complex and nuanced understanding of postcolonial cultural production," as it is "attentive to the implications of the heterogeneity embedded in

97 With this term, Schein describes Othering processes that "take place interethnically" (Schein 73). That is to say when one class, ethnic group, or social component of a non-Western society (Schein mentions China as an example) Orientalizes another, becoming the agent of Orientalist representation. Schein refers to the same process also as "internal Orientalism" (Schein 73).

98 This section refers to three works by Lisa Lau: "Re-Orientalism: The Perpetration and Development of Orientalism by Orientals" (2009); "Introducing Re-Orientalism: A New Manifestation of Orientalism" (2011); and "Introducing Re-Orientalism Theory and Discourse in Indian Writing in English" (2014). As Lau herself points out in "ReOrientalism," similar processes of self-Orientalization have been addressed earlier although denominated differently. Lau mentions ethno-orientalism (Carrier, 1992), self-orientalism (Dirlik, 1996), internal orientalism (Schein, 1997), and reverse Orientalism (Mitchell, 2004) (Lau 4).

99 I disagree with Lau's use of the term "Oriental" with reference to the authors she addresses in her study. I believe, however, that by her re-introduction of the term Lau sought to emphasize the paradox intrinsic to the concept of re-Orientalism. 
categories such as the West and the East" (Lau, "Introducing Re-Orientalism: A New Manifestation" 2).

While Lau conducts her studies on re-Orientalism mostly within the framework of South Asian (specifically Indian) writing in English, ${ }^{100}$ the concept is particularly helpful if applied to the Turkish context, where processes of re-Orientalism can be located in texts that are set in the socio-historical context of Kemalism itself. Indeed, re-orientalism is an illuminating category if applied to Seven Houses and Croutier's work, as important similarities between Croutier and Lau's re-Orientalizing authors become evident. ${ }^{101}$ In Seven Houses the plot unfolds in the crucial moment when Kemalist Turkey intensifies late-Ottoman, re-Orientalist discourses to inscribe Turkey into a Western-centered narrative of progress. It addresses the Kemalists' re-Orientalist mindset and the necessity to draw a line within the nation's present and its imperial past through the stories of two destroyed gardens.

As a diasporic author of Turkish origins, Croutier re-Orientalizes her home culture in her novel. In fact, Croutier seems eager to affiliate with the Western Orientalist tradition, as, among the genres and authors who inspired Seven Houses and The Palace of Tears, she mentions " $19^{\text {th }}$ century travel fiction, especially French travelers who went to the Near East" and other authors such as "[Rudyard] Kipling, [Samuel T.] Coleridge, [Percy B.] Shelley, George Eliot, William Blake, and Gustave Flaubert" (Croutier in Rosen 63). By openly tracing the genealogy of her work back to Western authors, Croutier positions her work in the Western Orientalist tradition, making Western conceptions of the Orient prominent in her own writing.

Yet, Croutier takes the discussion of re-Orientalism further, as re-Orientalism in Seven Houses has a specific function: it exposes the process through which Turkey's Ottoman legacy and culture needed to be Othered in order to sever the country's imperial past from its Westernized present. Through the image of

100 In her categorization of Indian writing in English, Lau distinguishes between "home authors," "sojourner authors," and "diasporic authors" (Lau, "Re-Orientalism" 573, 575). In brief, home authors permanently reside in South Asia, diasporic authors permanently reside abroad, and sojourner authors "travel frequently from within South Asia to other countries, living and working and dividing their life and time between two or more countries" (575).

101 Other similarities that bring together Lau's re-Orientalist writers and Croutier are the blurred border between life writing and fiction and these author's self-positioning in a difficult interstitial space. See Lau's "Re-Orientalism: The Perpetration and Development of Orientalism by Orientals," especially 585-586. 
Ottoman gardens and their demise, Croutier shows how, within the Turkish national context, past and present could coexist and respectively play the role of object and subject of the Orientalist representation. In this perspective, the novel exploits the Ottoman past as a repertoire of Orientalist tropes and images for which, as Lau's works point out, the demand of global literary markets is still high $^{102}$ (Lau, "Introducing Re-Orientalism: Theory and Discourse" 11). The same Ottoman past is later dismissed as an abstraction, an Oriental fable for which little room is left in Turkey's modern, secular present. On the one hand, the novel seems to subscribe to the dictates of Kemalism, especially to the expulsion of the Ottoman past from official historical narratives. The characters' acceptance of the radical reinvention of Istanbul's urban landscape, their gleeful exultation at the flow of American commodities, and Maria's desire to not be left behind by her family point towards her willingness to also draw a line between the country's modernity and its past. On the other hand, the abundance of Ottoman themes and Ottoman nostalgia, the use of fairy-tale elements, and the celebration of Turkish folkloric cultural practices ultimately distance the novel from the Kemalist mindset. These factors complicate Croutier's response towards Kemalism, defining it as much more ambivalent than Shafak's.

Building on Lau's theory, not only does Croutier emerge as a re-Orientalizing author, she also takes the notion of re-Orientalism into the terrain of what I here term 'hyper-Orientalism.' Besides strongly exoticising Turkish culture and its 'indigenous' elements (Sufism, the Karagöz theatre, Ottoman folklore), Croutier integrates elements from cultures further East than Turkey, which contribute to making Turkey stranger, more exotic, more unfamiliar; in a word, more 'Oriental.' This tendency is particularly evident in the figure of the patriarch Iskender and his plantation. When Iskender's granddaughter, Amber, visits her grandfather's office at night, she is welcomed by

a jungle of velvet drapes, Buddha heads, carnivorous plants, golden braziers, ancient tombstones, assorted smoking-pipes, maps, musical instruments, peculiar ephemera, [...] clumps of brown photographs pinned on the walls. One showed two men in Bedouin clothes smoking nargilehs in front of a coffee shop somewhere on the Silk Road, a backgammon board between them. Another showed Iskender on camelback dressed like a Sheik. (94)

102 On the popularity of postcolonial exoticism on the Anglophone literary market see Lau's "Introducing Re-Orientalism: Theory and Discourse in Indian Writing in English," Graham Huggan's “The Postcolonial Exotic” (2001), and Commodifying (Post)Colonialism: Othering, Reification, Commodification and the New Literatures and Cultures in English, edited by Rainer Emig and Oliver Lindner (2010). 
This passage presents Iskender's collection of mementos of his travels to the East. Among curiosities of striking vagueness, the reader stumbles on the Buddha heads, which suggest that this is not merely the office of a Turkish plantation owner, but a space welcoming different Orients, a synthesis of "the great Asiatic mystery" (Said, Orientalism 44). The photographs on the wall add indeterminacy to the Orientalized space of the office: the reader is unsure whether the photographs of the Bedouin-clothed men, the water pipes, and the coffee shop were taken in Turkey or further East - "somewhere on the Silk Road." The walls of a Turkish gentleman's private office plunge the reader in a mysterious and undefined Orient, whose boundaries are stretched beyond recognition. The Buddha heads and the Bedouin and Sheik clothes contribute to the hyper-Orientalization of a Turkish space, as if Turkey itself were not 'Eastern' enough for the purposes of the novel. In addition, the diversified mementoes stored in Iskender's office not only enhance Turkey's potential for exoticization, but also offer a commentary on the vastness of the Ottoman Empire and the cultural diversity it subsumed, adding a layer of imperial nostalgia.

Iskender's office is not the only space that reveals the author's tendency towards hyper-Orientalization: the garden itself - or silk plantation - is another significant one. The silkworm used by the İpekçis are, in fact, Chinese: "the most coveted silk moth, a secret that the Chinese had guarded viciously for many centuries" (64). The adventurous journey that leads to their discovery provides the occasion for another enumeration of suggestive Oriental treasures brought back by Iskender, including "musk, fabrics, diamonds, rubies, perfume, rhubarb, and other assorted objects of desire" (64). Similar to Iskender's office, the wardrobe of his daughter Aida contains a variety of exotic robes that have populated Western ethno-chic fantasies for centuries, among which "Mandarin gowns, saris and sarongs, charshafs and chadors, caftans, kimonos, and kebayas, pallium, peplum, peplos" (64).

In Croutier's novel, Turkey's exoticism is a result of the conglomeration of different exoticisms. Rather than investigating the cultural specificity of the country, Croutier constructs an imaginary Turkey reminiscent of Said's Orient: a field of "considerable geographic ambitions" and a "confusing amalgam of [...] vagueness and precise detail" (Orientalism 50). The participation of other 'Orients' in the portrayal of this fictional Turkey helps the novel to amplify the country's exotic potential - otherwise 'confined' to its Ottoman dimension.

In his collectionist fervor and exotic masquerading, the Turkish patriarch and adventurer Iskender brings to mind the figure of the Western Orientalist venturing into unfamiliar spaces. This sheds an ambivalent light on the issue of 
Orientalism in Croutier's novel, as the re- and hyper-Orientalization of the Turkish space conceal an attempt to relocate Turkey as predominantly Western, and push the boundaries of the Orient further East. Significantly, members of the İpekçi family oscillate between Ottomanesque manners - or even hyper-Orientalist exoticism - and their wish to participate in the rampant Westernization of the country.

It has become clear that, in Seven Houses, Ottoman tradition can no longer be the main source for the construction of contemporary Turkish identity. Seven Houses and its gardens also indicate that Turkey has become hybrid and Americanized. In the first years of the republic, the İpekçis adopt a strongly Americanized domesticity: after losing all their garden-like properties, they conform to a modern, anonymous, and bourgeois existence. Their everyday life is now replete with American products such as washing machines, refrigerators, Kleenex tissues, toilet paper and wall-to-wall carpeting. In addition to consuming American products, they also adopt "certain types of politics" (Raw 84) and imported American philosophies, such as of pragmatism, functionalism, consumerism and the "virus of time" (Seven Houses 123).

Laurence Raw's assessment of how the dissemination of American products has impacted Turkish identities is helpful to define Americanization in Seven Houses. In response to Edibe Sözen, who considers the spread of American commodities a threat to Turkey's indigenous culture, Raw argues that "the process vulgarly called 'Americanization"' should rather be addressed as "vertrossing, an untranslatable Dutch word conveying the idea of mediation and creolization" (Raw 86). Croutier's openness towards Western models, and towards America less as an actual geographical space than an idea, is an invitation not to uncritically imitate and reproduce Americanness, but to creatively adapt it. Through the contact with American cultural and material products, Croutier's characters appear as actors involved in Raw's vertrossing, who "produce hybrid products" and thus "become producers themselves, utilizing these cultural products [...] both for their own ends, and for the benefit of the nation" (Raw 85). In the cottage garden, Amber and Nellie witness Ottoman magic and, although they fail to understand it completely, they inherit part of it and are entrusted with the task of forwarding it into a modern, Americanized Turkey, or into the U.S. itself.

Orientalism and the characters' posture of acceptance reveal a compliance with the American influence on Turkey. The novel supports the Westernization efforts of Kemalist Turkey by referring to American cultural influence as one of the most prominent component of Turkish national identity, not to mention the economy and foreign policy. Consequently, not only does Seven Houses approve 
of the country's Westernization by showing how Turkish characters adapt to modernity without opposing resistance, but it also perpetrates the same re-Orientalist rhetoric adopted by the Kemalists by constructing the Ottoman past through Orientalist tropes. The novel's atmospheres, however, betray a great fascination for and nostalgia of Turkey's imperial culture, which is portrayed as a source of beauty and magic. The prominence of Ottoman themes grates against the proWesternization message that seems to permeate the novel, making Seven Houses a multilayered and ambivalent text.

This argument can be consolidated further by comparing Seven Houses to Pamuk's The Black Book, another novel that addresses the issues of urbanization and Americanization in Turkey and makes a symbolic use of gardens. In its cautious critique of urbanization, Seven Houses settles on a more moderate position than The Black Book, as it describes urbanization as an agent that changed Turkey only superficially: under the concrete buildings, an authentic Turkishness continues to exist, in the form of the buried ruins of ancient Anatolian civilizations. The superficiality and inoffensiveness of urbanization in Seven Houses is captured by the narrating voice of “The Spinster's Apartment," the İpekçi’s new home in Ankara:

little did anyone know that underneath, less than twenty meters, a whole ancient city lay not yet uncovered. So, after all I was an old soul deep down. Despite the mask. (122)

While Pamuk repeatedly denounces the loss of a Turkish 'soul' (although The Black Book points at essentialist notions of culture as deceptive), Croutier insists that the soul of the Turks is intact behind the façade of Americanization/ Westernization. "Deep in their hearts," the narrator announces, "Turks were still nomads" (209). Unlike the supposedly permanent nomadic nature of Turkishness, concrete buildings are made to "last no more than ten or fifteen years, then self-destruct" (ibid.). In spite of Turkey's urbanization, "nomads resist the threat of permanence" (121). In The Black Book, instead, a character depicts the urbanization of Istanbul as a much more alarming phenomenon:

In the autumn of 1957, you wrote an angry, mournful but carefully worded column about the mosques going up in the new suburbs of our fast-expanding city; [...] because your point was that these new suburbs lay siege to the city proper and surrounding us on all sides, and to see those concrete minarets pressed against the sky was to gaze upon a forest of hostile lances. (The Black Book 352)

The author's militaristic language portrays a city under siege, threatened, "surrounded," and "pressed" by a hoard of "hostile lances." Even though the proliferation of religious edifices such as mosques and minarets seems to pose a 
conspicuous threat to the city, the ever-growing suburbs, with their concrete architecture, are just as sinister. The same is true for the novel's position on Americanization - of which The Black Book is much more critical than Seven Houses, or any other Turkish American text analyzed in this volume. In the chapter "Bedii Usta's Children," for instance, characters are less inclined to consider Americanization as functional to the making of Turkish identity, and rather react against it with melancholic obstinacy.

If in The Black Book Ottoman cultural memory is lost and impossible to retrieve, in Seven Houses it was never lost completely. The Black Book resists Americanization, while Seven Houses settles for an attitude of hopeful acceptance. Similarly, while Seven Houses describes the rupture with the Ottoman heritage as necessary, The Black Book nostalgically clings to the past. On the one hand, Seven Houses does hold Americanization responsible for the destruction of the Ottoman Eden. On the other hand, the text internalizes Western conceptualizations of the East, replicating Orientalist canons in portraying the Ottoman Empire as a pre-colonial paradise, and labeling it as a folkloric impossibility in the context of the modern Turkish republic.

\title{
Wells and National Amnesia: Orhan Pamuk's The Black Book
}

\author{
What happened to the secret inside the pit that later became the gap? \\ When it turned into the gap, what happened to the pit and everything in it? \\ Orhan Pamuk, The Black Book
}

Once again, the choice to include a novel written in Turkish offers a valuable starting point for a comparative analysis of nature and garden imagery in Turkish American literature and literature in Turkish that clearly traverses national boundaries, but does not develop along bicultural lines. One of the main aspects that differentiates the garden in Orhan Pamuk's The Black Book from other examples explored so far is that it is more deeply grounded in the experience of collectivities rather than individuals or families. The 'garden of memory' in this novel emerges from the beginning as a collective metaphor articulated on a cultural level, without the mediation of a family story. First of all, Pamuk's garden is a backyard shared by the many families that inhabit an apartment house in Istanbul (not unlike the modern apartment building in Ankara the İpekçis move to in Seven Houses); secondly, the story of this shared courtyard - and its well appears in a fictional column of the national newspaper Milliyet, which targets a national readership and presents the garden as a central metaphorical space in Turkish culture. 
The Black Book's charismatic co-protagonist, Celâl, works as a columnist for Milliyet. In one of his columns, he reminisces about the apartment house where he was born, now in decay, and his memory goes directly to a pit - also called "the dark airshaft" or "the well" - in the building's backyard. This well, by then devoid of any practical function, was still considered the dwelling space of evil spirits by the tenant families. Pamuk modifies this traditional narrative, rooted in centuries of Islamic folklore, by concentrating less on its magic aspects like Croutier did in Seven Houses, and turning it into a metaphor for the disruption of the Ottoman heritage in modern Turkey.

In many ways, the basement structure called the pit, the gap, the well, or the dark airshaft ${ }^{103}$ in The Black Book is comparable to Maria's well in Seven Houses, which hosts the phantoms of a mystic and multicultural past. The Black Book provides another representation of wells as mysterious structures infested with supernatural creatures, both real and imagined, and it echoes Turkey's traditional "distaste" for underground structures (Cerasi 132). In addition, the novel inscribes its well in a lineage of Turkish literary wells:

it was of mythic proportions, [...]. It was, I was sure, the same pit Sheikh Galip described in Love and Beauty and Rumi in Mathnawi. Lower a pail into it, and something cut the rope; they told us there was an ogre lurking in its darkest depths, a black ogre as big as our building. (206)

Croutier's wells, very much like Shafak's nature, appear as metonymies of private family stories and only later does their vaster cultural value become clear. By contrast, Pamuk's well immediately latches onto a collective or even national dimension: first, because it is connected to a multiplicity of family stories, as it is located in a shared courtyard and not in a family garden. Second, because its origins are rooted in canonic texts of the Turkish Sufi tradition. ${ }^{104}$

103 An in-depth analysis of the Turkish terms for pit, gap, well, and airshaft, as well as a critical assessment of Freely's translation choices, would be extremely valuable but are not within the scope of this work.

104 Sheik Galip was an eighteenth century Turkish Sufi poet. His romance in verses Beauty and Love (Hüsn ü Aşk) is his most notable work; see Dilek Direnç, "Şeyh Galip: Beauty and Love" (2007). It is important to note that the first names of the two protagonists of The Black Book, Galip and Celâl, are meant to remind Turkish readers of Sheik Galip and Jālal ād-Din Rumi. This detail, like many others, would go unnoticed by the majority of non-Turkish readers and points at the predominantly 'national' quality of Pamuk's fiction. 
Besides being the dwelling of supernatural beings, one of the most fascinating aspects of the well in the shared courtyard is its 'anti-museumizing' or "counterarchival" (Göknar 122) ${ }^{105}$ function.

There was all variety of ordure in these basement passageways, things so disgusting they cried out for their own words: [...] unlucky forks and knives shaken into the petroleum void from the folds of flowered tablecloths, orphaned socks shaken from the folds of sleepy bed-sheets, dustcloths, cigarette ends, shards of glass from broken windows, crashed lightbulbs, shattered mirrors, rusty bedsprings, the armless torsos of pink baby dolls whose long-lashed eyes continued to open and close with hopeless obstinacy, deflated balls, soiled children underwear, the carefully shredded remains of suspect magazines, dubious newspapers, and photographs too fearsome to contemplate. (207)

Traditionally, the function of a museum is to salvage and exhibit selected objects that appear to its curators as representative of an epoch, culture, or cultural phenomenon. Museums, and the "museumizing" imagination, Benedict Anderson argues in Imagined Communities, are thus highly politicized (Anderson 107). The Kemalists had carefully selected the elements that would configure Turkey's cultural memory and re-imagined national identity along primarily Western lines, hoping to confine unwanted cultural legacies to oblivion. In The Black Book, Pamuk suggests that a similar selective effort was being made at a smaller scale by Turkish families. Anderson confirms that museumizing efforts happen on the national as well as the domestic level. In Imagined Communities, he speaks of "photographs, birth certificates, diaries, report cards, letters, medical reports, and the like" as elements that "record a certain apparent continuity" (Anderson 204). As a consequence, their disruption betrays the hope for a rupture in historical and familial narratives. Jan Assmann's concept of "Gedächtnis der Dinge," the memory of things, helps us to outline the implications of the choice to rid oneself of objects. Assmann affirms that human beings have always been surrounded by things that embody their ideal of practicality, comfort, and beauty. Thus, things return the very image of their owner; they remind one of oneself, one's past, one's background (Das kulturelle Gedächtnis 20). ${ }^{106}$ It is therefore logical that the

105 Göknar claims that a "dissident archival mode" permeates Pamuk's work (Göknar, Orhan Pamuk 127). Pamuk's "subversive counter-archives" in The Silent House, The White Castle, and My Name is Red, according to Göknar, subvert the "official Republican discourses" and express the urgency to revise "secular modernity through a rejection of the authority of Republican historiography" (122). The Black Book is certainly to be listed as an example of this "dissident archival mode."

106 "Der Mensch [ist] seit alters von Dingen umgeben, in die er seine Vorstellungen von Zweckmäßigkeit, Bequemlichkeit und Schönheit, und damit in gewisse Weise sich 
tenants of Pamuk's apartment house - a metonymy for the Turkish nation in its entirety - decide to discard objects from their past that do not return an acceptable self-image, or return one they have learnt to dissociate themselves from.

Everyday life objects - such as cutlery, food rests, or toys - that are thrown or fall from the higher floors' domestic universe are gathered in the pit and form a disturbing collection that mocks and subverts the museumizing practice, gathering artifacts that should be forgotten rather than remembered, thrown away rather than preserved. Among other things lying on the bottom of the well, the image of "photographs too fearsome to contemplate" significantly expresses this subversion, as the well swallows photographs which would otherwise not be collected in family albums and would not serve the function of preserving memory. Those elements that were expunged from Turkey's collective memory, however, did not simply cease to exist but gathered underground, forming an alternative historical narrative.

Two passages confirm the initial assumptions that, first, wells connect to a collective or national dimension rather than an individual or familial one; second, they address the issue of collective memory and the repression of a shared past. In the chapter "O Brother Mine," Galip, receives an anonymous phone call by one of Celâl's readers, who lists all the wells that ever appeared in Celâl's columns and demonstrates the literary and metaphorical significance of wells in Turkish culture.

"So let me pass quickly over the wells of divan poetry, and the well into which Rumi threw the body of the beloved Shams, or the wells of The Thousand and One Nights, [...] or the wells said to be inhabited by witches and giants, or the wells lurking in the gaps between apartment houses, or the dark and bottomless pits in which you claim we lost our souls." (352, emphasis added)

The pronouns "we" and "our" imply that the wells, pits, and gaps of Turkey witnessed a national-scale loss. Göknar points out another passage in The Black Book where Pamuk uses the pronoun "we" in reference to the Turkish national community: a column by Celâl mysteriously written twenty-five years after his death. There, "Pamuk/Salik ${ }^{107}$ uses the pronoun we, evoking the imagined community

selbst investiert. Daher spiegeln die Dinge ihm ein Bild seiner selbst wieder, erinnern ihn an sich, seine Vergangenheit, seine Vorfahren usw."

107 In the passage Göknar reports, Celâl openly addresses his community of readers. The reference to a national collectivity is therefore more obvious. "But if I were alive today," Celâl writes, "this is what I'd want to tell my readers: We ourselves are to blame as well” (Pamuk quoted in Göknar, "Secular Blasphemies" 323). In the analysis of this column by Celâl, Göknar equates the narrator with the writer, claiming that, 
of Turks" (Göknar, "Secular Blasphemies" 323). In the quoted passage, "we" can hardly refer to the inhabitants of the apartment building described in Celâl's column, since the reader does not know whether the man making the phone call used to live there or not. It probably indicates the vast readership of the national newspaper for which Celâl writes. As such, "we" stands for the Turkish national community as a whole, and the "souls" which have been lost inside these wells are those of the Turkish nation.

In the same dialogue between the anonymous phone caller and Galip, whom he mistakes for Celâl, the man uses the pronoun "we" in connection to the well metaphor: "Rather than raise our eyes to the sky to look at concrete minarets we should look instead into the dark, dry, snake- and soul-infested wells of our submerged and forgotten past"108 (352). Therefore, not only does The Black Book make the function of the well as the residence of Turkey's forgotten memories explicit, but it also extends this function to the underground. Along with wells, also cellars and underground corridors function as an anti-museum that subverts Turkey's official national memory.

The unpleasantness connected to the discarded objects on the bottom of the well sheds light on the feelings the Turkish population may have towards its own repressed cultural memory. The "petroleum void" (207) into which objects are thrown is reminiscent of the shiny black bottom of a well, concealing not ogres and jinnis like the family wells in Seven Houses, but the much bloodier threat of broken glasses and rusty metal. The inventory of discarded objects provided by the narrator opens a scenario of scabrous intimacies and family secrets, disorderly bodily functions (the soiled underwear), and clandestine sensual pleasures (the suspect magazines, the dubious newspapers). Particularly striking are the references to a somewhat monstrous humanity producing mutilated dolls and "photographs too fearful to contemplate" (ibid.). The embarrassment Turkish families feel towards their past is conducive to one of the most prominent themes of The Black Book, namely, the desire to forsake one's own identity and be someone else - which is center stage in The Bastard and The Saint as well, especially in the figures of Asya, her father Mustafa, Omer, and Gail. The Black Book describes this attitude as epidemic in republican Turkey, where everyone, from single citizens down to the country itself, finds his or her own identity repulsive

through Celâl, Pamuk himself is commenting on "his transformation as an author (once national, now global)" (324).

108 It is my impression that the anonymous phone caller uses the terms "well" and "pit" interchangeably. In other areas of the text, however, the two terms convey different ideas. A more detailed analysis of the different terms and their uses will follow shortly. 
and desires the lives of others. Turkish American novels maintain the focus on this narrative and simultaneously complicate it by engaging with the American, Armenian American, and Turkish American experiences.

This phenomenon of collective denial, implying an imposed lack of identification with the nation's imperial past and tradition is addressed frequently in Turkish American literature. It recurs in Shafak's The Bastard of Istanbul and in her articles "Memory-less Turkey/Amnesiac Turkey" and "When a Nation is Afraid of Having a Memory." There, she denounces the way Turkey "turned her back to [her] Ottoman past, and pretend[ed] to have started history from scratch the day the modern nation-state was established" and felt "uncomfortable, if not embarrassed, about [its] 'Eastern' ways and pretend[ed] to be Western and nothing but Western" (Shafak n.p.). The image of the wells swallowing Turkey's repressed past and preserving it in a horrific anti-museum adds one more precious element to this discourse.

There is a moment in the history of the apartment house when the well, or the pit, becomes the "gap"; this moment corresponds to the 1950s and the second half of the $20^{\text {th }}$ century, when Istanbul experienced rapid urbanization. Tall concrete blocks of flats were raised next to Ottoman houses and buildings in order to respond to the rapid increase of the urban population due to inland migration, as well as to evoke the outlook of modern Western cities (see Kucukmehmetoğlu and Geymen, 2009). The apartment house described in Celâl's column is part of the older urban texture, since "in no ways did the building resemble the ugly concrete affairs that would soon line the avenue like a filthy wall" (206). In addition, the building is initially embedded in a typically Turkish neighborhood. This situation, however, does not last:

When the apartment house was first built, there were empty lots on either sides [...] and you could see the mosque, the streetcar line, the girls' lycée, and Alâaddin's shop. [...] But the empty lot next door was sold to a builder, and soon there was a huge apartment house standing between us and the world, leaving nothing to contemplate but a row of new windows three yards away. This was how the gap into the well was formed. (206-207)

The translator's decision to use different words in reference to the periods before and after Istanbul's urbanization is very indicative. The Oxford English Dictionary defines a "pit" as "a hole in the ground, and related senses" or "a natural or man-made hole in the ground, usually a large or deep one." While a pit seems to unequivocally be "a hole in the ground," the definition of "gap" lays emphasis on the figurative use of the term. The first definition provided by the OED does not define a gap as a physical phenomenon, but as an abstract notion: "any opening or breach in an otherwise continuous object; a chasm or hiatus." The physical quality of such "breach" 
is only covered by the second definition: "a breach in a wall or hedge, as the result of violence or natural decay." Freely's choice of terms is therefore particularly pertinent to the function of Pamuk's gap, which indeed marks a "hiatus" in the otherwise continuous history of Turkey. The moment that turns the well from a communal source of water and the abode of mythological monsters into a gap where Turkish collective memory is lost can easily be associated with the reforms and measures implemented during the republican period, which opened the doors to an urbanization process that aimed to conform Turkish cities to Western architectural canons. ${ }^{109}$

When some of these objects are occasionally brought back to the surface and shown to the tenant families in the hope of finding the owner, they vehemently repudiate the objects found in the disturbing depths of the pit/gap:

from time to time, the janitor would retrieve some of these objects and wander from floor to floor, holding the piece of filth in front of him, like a policeman who's just collared a criminal, but no residents ever owned up to the dubious objects he dragged from the muddy underworld: "It's not ours," they would say. "It fell all the way down there, did it?" They uttered the word there as if it were a fear that they were desperate to escape and forget forevermore. (208)

There is a fundamental difference between the social function of a well - providing water for the community - and the pit, into which tenants carelessly drop their waste. If in the first case the well is a symbol of communal responsibility, in the second case the pit signifies its exact opposite: the lack of responsibility

109 In East West Mimesis (2010), Kader Konuk reflects on the symbolic power of fire in the context of early $20^{\text {th }}$ century urbanization in Istanbul. Konuk quotes a passage from Pamuk's Istanbul: Memories of a City in which the narrator expresses his mixed feelings about the destruction of Ottoman Istanbul due to frequent fires that ravaged the wooden structures of imperial architecture: "Ours was the guilt, loss, and jealousy felt at the sudden destruction of the last traces of a great culture and a great civilization that we were unfit or unprepared to inherit, in our frenzy to turn Istanbul into a pale, poor, second-class imitation of a western city" (Pamuk in Konuk 135). In the narrator's imagination, Istanbulites welcome fire with "an uncomfortable mix of pleasure and despair" (Konuk 135) - not unlike the relief they feel when letting embarrassing mementos slip to the bottom of a well, and thus doing away with cultural memory. Konuk notes that this dual attitude towards the destruction of Istanbul's Ottoman past is not limited to Pamuk, but appears in other examples of literature about late-empire and early-republic modernization, and she mentions Ahmet Hamdi Tanpinar's non-fiction as an example for that. Konuk adds that, for Tanpinar and Pamuk, "fire invokes memories of the past, melancholy, transformation, and even modernization" (Konuk 134). Indicatively, the patriarch's garden in Seven Houses is also destroyed by a fire. 
towards collective spaces and the disregard for personal properties, which can be disposed of when no longer functioning. If the well seems to be at the center of practices of community-building in Turkey, its successive embodiments (the pit and the gap) stand for their erasure.

The opposition between a domestic "here" and a "down there," emphasized by the narrator's use of italics, evokes the imbalance between a central "Here" and a peripheral "There," a Self and an Other. Within the apartment house, the domestic "here" points at the realm of the socially acceptable, whereas the "there" inside the well/pit/gap indicates a set of objects from which the building's inhabitants are eager to separate. The parallel between the community of the apartment house and the Turkish national community suggests a similar imbalance within Turkey itself as a nation that is split between an inner "Here" (an official, admirable, and Westernized way of being Turkish), and an outer "There" - a shameful legacy that it seeks to "forget forevermore."

In contrast to the other novels examined in this chapter, The Black Book openly denounces the influence of 'American cultural imperialism' during the republican period, and how seriously it impacted Turkish identity, cultural memory, even self-perception. In the chapter called "We Lost our Memories at the Movies," the novel critiques Hollywood's penetration of Turkish culture with alien habits and models that compromised Turkey's self-perception and brought about the loss of national memory. Movies are described as a weapon used by "secret and invisible masters" (63) or "new masters" (128) in order to dilute national identity and turn Turkey into a docile ally. In the following citation from "We Lost our Memories at the Movies," "new" imperialist strategies and "old" ones are compared:

Instead of bringing new settlers to populate this new state, as their predecessors had done a thousand years ago, [our new masters] would turn the old inhabitants into 'new people, tailored to serve their purpose [...] The new plan was to erode our collective memory with movie music. Church organs, pounding out chords of a fearful symmetry, women as beautiful as icons, the hymnlike repetition of images, and those arresting scenes sparkling with drinks, weapons, airplanes, designer clothes - put all this together and it was clear that the movie method proved far more radical and effective than anything missionaries had attempted in Africa and Latin America. (126-127)

The juxtaposition of religious elements (the organ, the hymn, Madonnas painted on icons) and secular ones evoking the tenets of Hollywood cinema (beautiful women, "scenes sparkling with drinks, weapons, airplanes, designer clothes") heralds a new type of cultural imperialism that sweeps Turkey. A conversion to Western aesthetic canons, imagery, and cultural products replaces the violent expropriation of the land carried out by the Western empires of the past. While no 
new "settlers" came to reside in what is effectively called a "new state" (Turkey was, in fact, a new state, as before 1923 there was no such thing as a Turkish nation), the local population was converted to alien ideas of secularism and progress. If the reference to "fearful symmetries," via Blake's poem “The Tyger," draws an immediate connection to British and European imperialism, in the second part of the passage the aesthetics of Hollywood cinema seem to predominate.

The missing ring that connects American cultural imperialism and the well metaphor is the visual nature of memory. In The Black Book, lost memory is mostly visual memory, as demonstrated by the images of the family archive, the photographs, the fading of the Turkish features from the faces of Galip and Celâl's fellow citizens, and the critique of Hollywood. Further evidence of the visual nature of lost memory is provided by an episode in which a boy threatens to blow up a movie theater in Istanbul and demands that "they give him his eyes back - the eyes that could see the old images" (127, emphasis in the text). The parallel that finally and definitively connects the loss of visual memory and American cultural imperialism can be found in the passage where the anonymous phone caller cites from one of Celâl columns. In the fictive text, Turkey's forgotten past is compared to

an eye that would go on haunt you for years, reminding you, wherever you went, of the sins of your past; it was not by accident but by design that you chose to describe this visual organ as looking "like a dark well in the middle of the forehead." (352)

The most salient difference between wells in The Black Book and their Turkish American manifestation lies in The Black Book's specific focus on a national perspective rather than on a transnational or bicultural one. The Black Book shows little interest in the hybridization of Turkish identity, and is rather invested in discussing, problematizing, and eventually deconstructing the dynamics through which memory and identity could be retrieved from under the mask of Westernization, and cleansed from alien - most notably American - influences.

Two elements have the power to bring back the memories that have been thrown into the well: children and flowers. In The Black Book, children are the only ones who show interest in the repulsive world of the pit/gap:

but, God be thanked, there is always someone willing to rummage through the forbidden pages of the past in search of treasures, and so it was in the long hallways (kept dark to save on electricity), when children (ah, children!) squirmed between the tightly drawn curtains and pressed their little foreheads against the windows to stare into the air shaft. (208)

Besides stressing the role children have in recovering Turkey's cultural memory, the quote illustrates once more the parallel between the objects deposited inside 
the airshaft and the forgotten pages of the nation's history, as searching the airshaft means to "rummage through the forbidden pages of the past." A mention to the salvific power of children can be found in Seven Houses as well: after the destruction of Iskender Bey's plantation and the moving to Ankara, Amber is the only character who continues dreaming of the plantation: "Amber drew houses, enchanted places with doors and windows and gables leading to other dimensions hidden behind ivy and vine, towers and cupolas and secret gardens" (Seven Houses 124).

Pamuk wraps up his well symbolism by mentioning individual gardens of memory that can be either "dry" or "heavenly" (The Black Book 134-135) - a distinction that suggests the absence and the presence of flowers and other garden amenities - and depicts the moment in which one retrieves one's (cultural) memory as the opening of flowers in a garden. This happens to Galip, when the questions posed by the anonymous phone caller who mistakes him for Celâl cause him to remember episodes from his life and Celâl's. Listening to the man's voice, Galip remains "amazed by the flowers that opened in the garden of his memory with each answer, intrigued by the seeming endlessness of the garden from which his opponent plucked his questions" (353).

A comparison between The Black Book and Seven Houses helps to shed light on the differences between Turkish and Turkish American literature and is functional on two levels. First, both novels present images of gardens and wells that acquire great prominence in the plot and become the vehicle of significant cultural symbolism. Second, The Black Book covers the years between 1960 and the 1980 military coup (Göknar, Orhan Pamuk 225), a period which Seven Houses also addresses towards the end. This is a crucial period in Turkish history as it displays the effects of Americanization on the country. The Black Book approaches the logic and consequences of American cultural penetration from the perspective of what Ferenbach and Poigner call "imperialist narrative" (Ferenbach and Poigner xix), concentrating on the loss of identity that ensues from the widespread adoption of American habits and aesthetics. In The Black Book, the narrator meets characters who lament the impact of Hollywood aesthetics on Turkish identity and self-perception. The novel occasionally comments on the impact of Americanization on the Turkish economy: Bedii Usta's mannequin atelier, for example, is doomed to irrelevance by the new Westernized aesthetics films have contributed to spread. By contrast, Croutier does not appear as critical of Americanization and indicates that Turkish history and identity are inevitably progressing towards hybridity. Westernization and Americanization infiltrate the lives of the characters at a very profound level. Camilla names her daughter 
after an English novel set in $17^{\text {th }}$-century England (Forever Amber, by Kathleen Winsor), turned into a movie by $20^{\text {th }}$ Century Fox. Camilla herself is repeatedly described through her uncanny resemblance to a Hollywood star of Mexican origins, Dolores del Rio. It seems almost inevitable that the family saga rooted in the glorious days of the Ottoman Empire would continue in the United States, where Amber and Nellie - the Turkish American generation who conclude the novel - return after having visited their native Turkey.

'Becoming someone else' is undoubtedly a very prominent theme in both novels and offers a powerful commentary on Americanization in Turkey. According to modernization theory, argues Bozdoğan, "the ability to imagine oneself as someone else or as being somewhere else, especially in America, was a major criterion distinguishing the 'moderns' from the 'traditionals"' (Bozdoğan 118). If the İpekçis are forced to re-invent themselves in republican Turkey as a bourgeois family, leaving behind their aristocratic past as the whole nation left behind its Ottoman heritage, The Black Book gravitates around the obsessive desire to be someone else and the contradictory necessity who remain who we are. While the İpekçis face the change with a cheerful spirit and succeed in reintegrating in the republican world, the characters in The Black Book struggle to find a way back to who they were, to the naïve delusion of a "non-American purity" (Fluck, "The Americanization of German Culture?" 30); some of them die in the process (Celâl), others remain trapped in an endless melancholia (Galip, Bedii Ustaa and his son). Paradoxically, the search for cultural authenticity in The Black Book is conducive to the realization that there was never such thing as an authentic Turkishness. Seven Houses, instead, regards Turkishness as a combination of influences and possibilities that never attack a supposed cultural core that one of the narrating houses identifies as the nomadic experience. The Turkish American chapter of the family saga can therefore be read as yet another manifestation of this attachment to nomadic practices. 


\section{Troubled Gardens of Turkey and the World}

This conclusive chapter shows how the Turkish American imagery explored within this volume resonates beyond the sphere of literary fiction produced by a restricted number of Turkish American writers and provides useful tools to interpret contemporary Turkey, as well as recent events of global significance. Here, I am going to look at how other Turkish American voices, such as journalist Elif Batuman and sociologist Fatma Muge Göçek, discuss one of the most controversial events in Turkey's recent history, the Gezi Park protests of June 2013. In hindsight, Erdoğan's response to the Gezi Park protests delivered a fatal blow to his international reputation. To put it with Batuman, after the Gezi events "the Western view of Erdoğan eventually soured” (Batuman, "Cover Story” n.p.). The protests in Taksim Square and Gezi Park began on May 31, 2013: their aim was to prevent the destruction of the park and the construction of a shopping mall. Erdoğan's government reacted with severity and what many considered excessive force, using water cannons and tear gas against the protesters. The demonstrations grew in violence and proportion and extended to other cities throughout the nation.

Batuman's and Göçek's columns in Daily Zaman ${ }^{110}$ and The New Yorker show that the categories, themes, and narratives that this study characterizes as Turkish American resurface in the Anglophone coverage of the Gezi Park events. Turkish American tropes can be encountered not only in fictional writing, but also in contemporary journalistic contributions, and continue to be part and parcel of Turkish public discourse. Today, like in the past, Turkish American narratives contribute ideas to the construction of a globalized Turkish identity and to debates on the evolution of the urban landscape, the biased quality of historiography, and the relationship with the United States.

Elif Batuman is a Turkish American journalist and novelist born in New York of Turkish parents. She holds a doctorate in comparative literature from Stanford University and has been collaborating with The New Yorker since 2010. Her debut novel, The Possessed: Adventures with Russian Books and the People Who Read Them, came out in the same year. She authored several columns on the Gezi Park events, but the most relevant text for the purposes of this chapter, titled "Istanbul's Troubled Gardens: The Flowers of Gezi Park," appeared in The New

110 A Turkish newspaper published in English and hosting articles by mostly Turkish, American, and English contributors. 
Yorker on July 16, 2013. Batuman begins by explaining her views of the protests, the tragedy of the wounded, and the absurd intervention of government gardeners planting thousands of flowers while the protest raged to prove Erdoğan's point that "protesters destroyed things, while the real environmentalists planted flowers" ("Gardens" n.p.). Later on, Batuman shifts the focus from Gezi Park to another, parallel, park project being developed in a different side of town, where the government plans to destroy the bostans of Yedikule (Byzantine vegetable gardens) and replace them with a new park. Batuman insists on the historical value of the bostans and expresses concern over their unnecessary destruction.

The bostans $[\ldots]$ line the southern edge of the fifth-century walls that enclosed Byzantine Constantinople. The gardens may be as old as the walls. An edict in the Theodosian Code (422 A.D.) designates space in the walls towers for storing produce and farming implements; a sixth-century Byzantine text mentions the cultivation there of "a large variety of green salads, endive, carrots, onions, and cabbage." [...] Yedikule means "seven towers," and refers to the four Byzantine and three Ottoman towers in the city walls; the train lets you off near the dungeons where Sultan Osman II met a terrible death. (“Gardens" n.p.)

Here Batuman claims that the bostans provide a direct link between modernity and a submerged pre-Ottoman and Ottoman past. She elaborates on this unique connection by adding that the gardens should be protected by UNESCO as intangible heritage.

"Intangible heritage" is a relatively recent category, and poses a tantalizing paradox: What if it's possible, by relinquishing our grip on physical objects, to arrive at a truer sense of historical place? A head of lettuce in Yedikule in 2013 isn't physically the same head of lettuce that grew there in 1013, but it's still a functional lettuce. [...] It's a marvellous and still underacknowledged gift to be able to [...] see, smell, and taste the actual living descendants of Byzantine lettuce. ("Gardens" n.p.)

Through the concept of intangible heritage, the gardens secure an ephemeral and yet very lively continuity between past and present Istanbul. In other words, the bostans make it possible for present-day Istanbulites to regain metaphorical entrance into the disavowed Ottoman past and thus can be configured, to put it with Ann Stoler as "ruins [...] that condense alternative senses of history" (Imperial Debris 9). Thanks to the image of endangered gardens, and the idea of the bostans as the remnant of a submerged Ottoman history, a connection can be drawn between Batuman's take on the Gezi Park protests and the trope of the garden analyzed in Chapter Four of this volume. Chapter Four ("Ottoman Nature: Natural Imagery, Gardens, Wells, and Cultural Memory in Republican Turkey") explores the function of natural symbolism and gardens in the work 
of Elif Shafak and Alev Lytle Croutier. The first part connects floral and faunistic elements with the search for identity in post-imperial Turkey in Shafak's The Bastard of Istanbul and The Saint of Incipient Insanities. Special emphasis is awarded to the preservation of collective memory in Turkish, Armenian, and Armenian American communities. The second part, mostly concerned with Croutier's novel Seven Houses, casts the disappearance of Ottoman gardens as a synecdoche for the erasure of Ottoman cultural memory in the country's passage from empire to republic.

In Batuman's article - as in Turkish American novels - the deplorable destruction of Istanbul's historical heritage is tantamount to the careless erasure of its Ottoman past, deemed unfit to participate in the government's vision of urban modernity. The strongest parallel can doubtlessly be established to Alev Lytle Croutier's Seven Houses, where the destruction of gardens is conjoined with a narrative of dispossession. The destruction of Maria's garden to allow for a road enlargement in Seven Houses evokes the Kemalist policies of confiscation and repurposing of land that belonged to the non-Muslim minorities of the empire. In Batuman's text, the narrative of dispossession shifts its focus from the sphere of ethnicity to that of class, as the new park project poses a severe threat to the community of farmers that depends on the bostans for a living.

They had worked at another bostan near the airport, but it had been paved over. Now they had to move again. The first woman said they had been given seven days' notice to vacate; her friend had heard rumors earlier - a month and a half ago. Both agreed that the bulldozers could come any day now. ("Gardens" n.p.)

A similar notion of dispossession emerges in Fatma Muge Göçek's article on Gezi Park "Where is Turkey Headed," where she proposes to read the Gezi events as conducive to a "Gezi syndrome" (Göçek n.p.). Göçek does not clarify the rationale behind her choice to connect the emotional aftermath of the demonstrations with the "Sèvres syndrome," possibly dismissing the link as immediate and obvious to her readers. Certainly, both syndromes engage with the idea of dispossession, intended as the disruption of the unperturbed identification between individuals and "the environment they live in" (Göçek n.p.). The phrase that, to Göçek, condenses the motives and atmosphere of the Gezi Park demonstration is a cry of dispossession: "How could they take my city away from me?" (Göçek n.p.).

Yet, for Batuman, the destruction of the bostan is primarily about the loss of public and private memory, and about the superimposition of a political vision on an existing landscape that is alive and redolent with history and meaning. Erdoğan's visions of modernity - the shopping mall at Gezi Park, the new 
park project on the ruins of bostans - clash with and are pursued in spite of the city's shared cultural past and the needs of the Istanbul population, and are therefore harshly condemned by the writers and her interviewees. Batuman sees the architectural interventions planned by Erdoğan's government as contrary to the preservation of the city's Ottoman past, which, considering that Erdoğan is a neo-Ottomanist leader, appears highly paradoxical. In addition to a cultural controversy, the bulldozing of Gezi Park and the bostans is, to Batuman, also an aesthetic dilemma, as Erdoğan appears deaf to the plea of Istanbul architects to join forces and reach a compromise between modernization and beauty:

architects and city planners [...] only wanted to open a conversation about the design of the park. [...] Couldn't the bostans be used not to obstruct the park but to enhance it - to make it a thing of beauty and meaning? Didn't they belong not to the Fatih municipality but to the whole city, and even the world? ("Gardens" n.p.)

The passage stresses the possibility to shape the Istanbul landscape as a synthesis of antiquity and modernity, avoiding what Pamuk in The Black Book would configure as a ghostly modernity standing on the ruins of a submerged past, as explained in Chapter One ("Imaginary Spaces: Representations of Istanbul between Topography and Imagination"). When Batuman conducts her interview, in fact, part of the bostans have already been buried under "several feet of rubble" (ibid.).

When Batuman characterizes Erdoğan as a charismatic male leader shaping the urban landscape top-down, immune to counsel and cooperation, a comparison with Atatürk is inevitable in spite of their antipodal political orientations. Erdoğan, writes Batuman, "has successfully fashioned himself as an Ottomanstyle ruler: tough, ambitious, grandiose [...] And yet, history is a multifaceted thing" ("Gardens" n.p.). The founder of Kemalism and the controversial neo-Ottomanist leader seem to share a similar interest in manipulating Turkey's history and cityscapes; once more, Turkish American writing resorts to voices of women to resist this process. In fact, in the introduction to this volume I defined Turkish American literature as permeated by a deep dissatisfaction with the identitarian narratives of Kemalism. Still nowadays, Turkish American voices continue to question, revise, or dismantle hegemonic narratives that intend to dissociate the Turkish population from its cultural memory. Evidently, Erdoğan’s Gezi Park project was perceived as such an attempt. Turkish American literature has not lost its political impetus, but the objects of its critique may have shifted after Erdoğan's turn to more authoritarian politics - which the Gezi Park events may have brought to the attention of the international community. 
Batuman's conclusive remark on the "multifaceted" quality of history enables another inevitable parallel to Halide Edip's personal battle against practices of historiography and religion dominated by single male heroes and prophets, which she re-wrote as the outcome of the work of a constellation of male and female figures, mothers, and gentle leaders. Edip's subversive historiography has been addressed in Chapter Two ("Rewriting History, Rewriting Religion"), which dealt with rewritings of history and religion in the works of Edip and Shafak. Chapter Two has showed how these authors reclaim Turkish history and religion from the predominantly patriarchal visions of Kemalism and orthodoxy, 'rewriting' them into a matrifocal perspective. In both cases, the rewriting of history and religion is characterized by a systematic search for parallels between Islam and Christianity and is carried out in a markedly American perspective.

A similar attempt to shift the traditional focus of Turkish historiography can be found in Batuman's argument as well. Batuman quotes archeologist Alessandra Ricci as she comments on how Istanbul's citizens and scholars "are now being forged to associate the land walls of Istanbul with conquests, wars, assaults, triumphs [...] but in reality most of the life of the walls was about something else, and the bostan is a testimony of this" (Ricci in Batuman, "Gardens" n.p.). The passage connects immediately to Edip's concerns about the excessively warlike and 'masculine' perspective on historiography, and her craving for a different focus:

the book seemed to squeeze my heart in an iron band, tightening with the ugly passions and demonstrations of power of the famous heroes. I wondered all the time what the simple little children were doing when all this bloody and cruel struggle was going on in a country. [...] Whenever I see or read of a great military hero performing his deeds, and of history or literature recording them, I wonder [...] not about the children only, but about the simple grown up people as well. (Memoirs 118)

The life and necessities of children and "simple grown up people" voiced by Edip in 1926 echoes that "something else" life on the Istanbul walls was about according to Ricci.

Yet, the analogies between Batuman's and Edip's texts do not end here, as the two share the focus on feminine perspectives. Batuman, like Edip but less vocally, invokes a transition from the male-singular form to the feminine-plural in Turkey's public discourse and history by connoting the bostans as almost entirely feminine spaces, as her interviewees in "Troubled Gardens" are all women. During her visit, Batuman starts a conversation with two elderly women in headscarves, and later on with two more women and a young girl. As they sort grape leaves, they tell the journalist to call them "the wronged women who work in the bostan' [...] Or no - just 'the wronged women”" (“Gardens” n.p.). Thus, Batuman's 
excerpt voices a desire for the reconfiguration of historiographical practices at large, one that is strongly reminiscent of the hopes and concerns expressed in Edip's memoirs. Batuman contrasts Erdoğan's intransigent efforts to pursue his own visions with the practical needs of the bostan women, not with the intent to deepen the sense of clashing interests but urging a negotiation.

Unsurprisingly, Batuman shares the Turkish American concern with heterogeneity and the hope that such unnecessary polarities as between governmental policies and citizens' needs, progress and antiquity, modernization and collective memory may be reconciled in Istanbul's cultural landscape. This is illustrated by a conclusive foray into Ottoman history, which Batuman projects as an example of tolerance and a viable model for the city's future:

it's possible to envision an altogether different Ottoman politics: one valuing adaptability, compromise, and a highly developed aesthetic sense. [...] When the Ottomans conquered Constantinople, they didn't destroy the Hagia Sofia but converted it into a mosque. [...] Then, drawing both on the knowledge he had gained from the Hagia Sofia and on his own particular talent, Mimar Sinan went on to build some of the most beautiful mosques the world had ever seen. ("Gardens" n.p.)

The passage contains an example of Ottoman utopia: one of the most prominent features of Shafak's writing. Shafak's Ottoman utopia, analyzed in Chapter One, casts the Ottoman past as a model of peaceful coexistence inspired by the paradigms of American multiculturalism and devoid of interethnic and interreligious conflicts. This construct also draws on the representation of the Ottoman Empire as a 'gentle empire' which allowed its subject populations to maintain their cultural identity, establishing a regime of ante-litteram multiculturalism in the conquered territories. The combination of cultural pluralism and a gentle domination is strongly reminiscent of American exceptionalist discourses, and resurface in Turkish American representations of the Ottoman Empire. In her article, Batuman locates the Ottoman utopia and the myth of gentle imperialism in the architectural sphere. The conquest of Hagia Sofia is thoroughly divested of brutality and regarded as the starting point of a civilization where colonizers and colonized (as well as their architectural traditions) could coexist and interact on almost equal grounds. Here, Batuman constructs her own Ottoman utopia by "replacing the tensions of the past and the present with seamless and beautiful images" (Mills 458).

A discussion of gardens and their cultural symbolism, so essential to Turkish American literature as well as to Batuman's "Troubled Gardens," can be found in Göçek as well, who dwells on the concept of environmentalism as one of the underlying values of the Gezi Park protests. In "Where is Turkey Headed," published 
in Zaman on June 16, 2013, Göçek contrasts the interests of a consumptionoriented, neo-liberal democracy embodied by the figure of Erdoğan, "where only consumers seem to be equal," with the concern for environmentalism: the "new vision" of the "educated youth" (Göçek n.p.). The preoccupation of the Turkish youth with the environment translates into their opposition to the erosion of nature (or urban green in the case of Gezi Park) as well as to the eradication of their urban landscape. The "environment in which they live" is also configured as an emotional space loaded with personal and collective memories. The Istanbulites resist the disruption of this emotional landscape for the sake of a political vision, Erdoğan's, which is "no longer in sync" with Turkey's vision (ibid.); much as Kemal's was, in earlier Turkish American texts, not in sync with the multifarious identity and complex history of the territory on which it developed.

This volume has attempted to describe Turkish American literature as the site of a privileged cultural dialogue between Turkey and the United States; in the course of this study, my aim has been to reflect on this dialogue and highlight the transnational framework around Turkish American literature. Both Göçek's and Batuman's articles stress the global resonance of the protests, defining Gezi Park as a transnational event, and they do so by mostly highlighting the affinity with the "Occupy Wall Street" movement in the United States. It is possible to read the transnational resonance of the Gezi Park protests through a dichotomy of anxiety and solidarity: two categories that appear as two sides of the same coin.

Anxiety of foreign interference seems to be a prominent theme in the Turkish and international coverage of the Gezi Park events. This is indicated by the proliferation of articles featuring conspiracy theories. ${ }^{11}$ In "Fear of Foreign Agents in Gezi," Laura Moth speaks of a broad concern about foreign involvement in the protests that not only affected the Prime Minister's rhetoric but was also voiced by the population ("I've seen wariness of foreign involvement among friends and acquaintances") and took the form of "outright hostility" in online coverage and commentaries (Moth n.p.).

Elements of anxiety of foreign interference appear, albeit moderately, in Batuman's and Göçek's articles as well, and there is enough evidence to characterize foreign interference as primarily Western and American. On the one hand, Batuman's "Occupy Gezi: Police against Protesters in Istanbul” (2013) features

111 Zaman offers a vast array of articles centered on conspiracy theories and anxiety regarding foreign involvement. To quote a few examples: Laura Moth's "Fear of Foreign Agents in Gezi," Aydin Albayrak's “Foreing Conspiracy Discourse May also be Used before 2014 Elections," and İhsan Daği's "What Is behind the Veil of Conspiracy Theories." 
an indirect connection between unrestrained consumerism and American imperialism. First, she voices the Istanbulites' shared frustration about the diffusion of shopping malls at the expense of historical buildings: "again and again, people have protested the destruction of some historical building or the construction of some new shopping center. Again and again, the historical building has been destroyed, and the shopping center constructed" ("Occupy Gezi" n.p.). Later on, one of her interviewees concludes his intervention with an utterly decontextualized but spontaneous "American imperialism to hell!" (“Occupy Gezi” n.p.). The man's exclamation betrays the conviction that the proliferation of shopping malls and the vanishing of the city heritage, as well as the Gezi Park events, might be a consequence of American cultural imperialism. On the other hand, Göçek's "consumption-oriented," "neo-liberal democracy" where "only consumers seem to be equal" is reminiscent of the American capitalist model (Göçek n.p.).

A counterpart to the discourse on anxiety in the Gezi Park debate is the transatlantic solidarity with the "Occupy Wall Street" Movement in the United States. Batuman and Göçek locate Gezi Park in a transnational perspective by establishing a connection with the American context, which is per se a legitimate parallel, since the Gezi Park movement adopted "the Occupy mantle" and decisively labeled itself as a global phenomenon, becoming "Occupy Gezi" (Moth n.p.). ${ }^{112}$ Batuman emphasizes the resonance the Turkish protests had in the American public discourse, which reacted by adopting the terminology and gestures of the Gezi protesters.

Erdoğan dismissed the protesters as [...] a handful of çapulcu ("looters" or "marauders") [...]. An English variant, chapulling, appeared in Wikipedia. Noam Chomsky released a video message indicating that he, too, was a çapulcu. By that point, Gezi Park had become a vast, confounding, utopian encampment, where thousands convened every day and hundreds slept every night, where the People's Çapulcu Barber gave free haircuts, the Çapulcu Library distributed free books, and the ideals of nationalism, Communism, socialism, feminism, and Kurdish self-determination seemed to coexist peacefully under slogans like "Everyday I’m Chapulling." (“Occupy Gezi” n.p.)

Batuman's account depicts Gezi Park as a diverse space capable of bringing Turkish nationalists and Kurdish activists, communists and socialists together: a "utopian" scenario mediated by the equalizing awareness of being "looters," the

112 The Gezi Park protest was not the first to "adopt the Occupy mantle." In 2011, a group of students of the Bosphorus University occupied the campus Starbucks for three days to protest against the price of food and beverages on campus. The protest quickly came to be known as "Occupy Starbucks." See for example "University Students Occupy Starbucks Shop," an article posted on Hürriyet Daily News on December 8, 2011. 
English language, and Noam Chomsky’s blessing. Göçek positions the Gezi protests in the horizon of "new social movements," but does not expand on which movements qualify as part of this category. Yet, she extensively elaborates on the similarities between "Occupy Gezi" and "Occupy Wall Street."

Another prominent voice joining the transnational debate on "Occupy Gezi" is Elif Shafak's, who wrote a piece for The Guardian entitled "The View from Taksim Square: Why is Turkey now in Turmoil??. Shafak's article touches upon some of the issues expressed so far: she comments on the Gezi Park controversy as yet another event that "widen[ed] the gap between the rulers and the ruled," and expresses preoccupation with the "stubbornly male-dominated" character of Turkish politics ("The View" n.p.). Most significantly, "The View from Taksim Square” seems to reassure foreign observers about the "Western' nature of "Occupy Gezi" by distancing it from another event which acquired immense global resonance: the "Arab Spring."

Shafak disapprovingly points at the precarious condition of Turkey's 'exceptional' status as the 'model' Muslim democracy - a denomination that keeps reoccurring in American political discourse from Bernard Lewis down to George W. Bush - blaming the AKP government for endangering the country's reputation:

There was a lot of talk about Turkey, with its overwhelmingly Muslim population and secular democracy, being a role model for the rest of the Muslim world. That spirit of optimism deteriorated dramatically. However, it can be revived once again if the government learns from its mistakes. ("The View" n.p.)

At the same time, Shafak discourages comparisons with the extremist exploits of the "Arab Spring" in what seems like an effort to reassure Western audiences that Turkey remains the exceptional model democracy of the Middle East.

Calling the recent events a "Turkish spring" or a "Turkish summer," as some commentators were quick to do, is not the right approach. It is true that Turkey has lots of things in common with many countries in the Middle East, but it is also very different. With its long tradition of modernity, pluralism, secularism and democracy - however flawed and immature it might be - Turkey has the inner mechanisms to balance its own excesses of power. (“The View" n.p.)

Inviting caution when it comes to comparing different national struggles for democracy and basic human rights is legitimate. What is striking about Shafak's text, however, is her investment in restoring Turkey's reputation as the most Western of the Muslim states, "one that boasts a long tradition of modernity, pluralism, secularism and democracy," thus attempting to re-establish the narrative 
of Turkish 'exceptionalism'113 so dear to American discourses on the Middle East. Besides, the text betrays a certain resentment at the quickness with which commentators have drawn parallels between Gezi Park and the "Arab Spring." In fact, the article's subheading wonders whether it is "fair to label this protest a 'Turkish Spring"'

This leads to the conclusion that the Turkish American perception of "Occupy Gezi" is understandably invested in the declension of the protests in a global, transnational perspective. After all, the analyzed articles appeared in Anglophone newspapers directed at international readerships. Yet, the connection between the Gezi Park protests and the American sphere is decisively preponderant: affinities with the "Occupy" movement are prominent and more deeply felt, but parallels with the "Arab Spring" are ignored or discouraged. Turkish American voices are eager to construct Turkey as a global agent, yet a certain imbalance can be noticed in their transnationalizing efforts. Turkey's transnational identity is in fact characterized by a strong bond with the United States, which appears to be kept center stage not only in the realm of fiction, but also in non-fictional texts that propose readings of Turkey's modernity and current public discourses.

Through the analysis of a series of narratives that recur in Turkish American texts - garden and natural symbolism, imaginary representations of Istanbul, matrifocal historiography, and Sufism - this study showed that Turkish American literature can be presented as a cohesive corpus of texts that reveal conspicuous similarities on the level of discourse (e.g., multiculturalism), symbols (e.g., gardens, wells...), and politics (e.g., Ottoman nostalgia and the critique of Kemalism). Moreover, the Turkish American imaginary is not limited to the realm of the novel, but extends through different genres, including journalistic writing and autobiography. The 'traveling' nature of these texts eschews direct canonization: they fit imperfectly in the framework of 'ethnic' or 'migrant' writing in the U.S. and cannot be categorized as Turkish literature either. Comparisons with texts written in Turkish such as Orhan Pamuk's demonstrated that the politics of Turkish American texts are those of diasporic literature, and the language in which they are written places them beyond the national borders - although not exclusively. Cross-readings with American canonic authors such as Whitman, Emerson, and Barth have been useful to measure the proximity of Turkish American texts to the American sphere. The comparison with Pamuk, instead, has been essential to locate Turkish American literature outside the national

113 For a discussion of 'Turkish Exceptionalism' see the introduction to this volume. 
sphere. While Pamuk's work crossed the national borders and now dwells in the world literature arena, Turkish American texts originated in an Anglophone literary context and may or may not return to the homeland. In spite of her English prose and Ottomanesque language, Shafak remains, to this point, Turkey's bestselling female author. The cases of Gün and Edip are more complicated, as their work was regarded with hostility within Turkey. Turkish American literature thus emerges as a hardly canonizable phenomenon, and yet not as an isolated, self-referential one. These conclusive observations showed that the narratives explored in this volume still permeate the way in which Turkish American voices comment on topical debates in Turkey. It also became clear that, in their coverage of Turkey's recent and less recent history, Turkish American writers read the homeland through the lens of American conceptual frameworks and interpret it for American and international readers. The effort to construct Turkey as a transnation was and remains a central feature of Turkish American literature.

It will be interesting to observe the futures of Turkish American literature. The rise of Erdoğan's AKP party in the early 2000s seemed to sanction the triumph of neo-Ottomanism over the Kemalists' obsessively Western trajectory, yet - and so much is not in doubt considering the historical conjuncture Turkey finds itself in - this did not result in a "country where we are all equal, friendly, and free" (Shafak, "Hrant Dink's Dream" n.p.). In the meantime, the Erdoğan presidency opened the doors to religious radicalization and made an abrupt departure from the "model democracy" paradigm the West had enthusiastically saluted; Shafak's claim that Turkey has the "inner mechanisms to balance its own excesses of power" ("A View" n.p.) resonates eerily in the aftermath of the failed coup d'état of 2016. At least for the time being, Erdoğan's authoritarianism has put the Turkish American aspirations on hold, and it seems unlikely that they will remain entirely unchanged. Will Turkish American literature re-evaluate Kemal's secularism, his mistrust of religion in the res publica, and his attachment to Western values? Which paradigm will it try to "revive," Ottomanism or the "model democracy"? 114 Will it shed the skin of political literature to rise as literature of protest? Will it revisit its positions or radicalize them? The fate of the Ottoman utopia is perhaps one of the most poignant questions. In her 2015 article, "Cover Story: The Head Scarf, Modern Turkey, and Me," Batuman affirms that "in the AKP-sympathetic world view, the Ottomans [...] enjoyed a vogue as models of enlightened Muslim multiculturalism" (Batuman n.p., emphasis added). With these words, Batuman puts the Ottoman utopia into perspective, acknowledges its status as a "vogue"

114 Cf. Shafak, "A View" and "Islands." 
determined by a specific political moment, and perhaps gestures at the possible ending of the romance with the Pax Ottomana. Considering the speed at which global dynamics seem to be shifting, it is this book's fate not to be exhaustive and welcome new studies on Turkish American literature that may address different political configurations in Turkey as well as in the United States and Europe. 


\section{Works Cited}

Adak, Hülya. "National Myths and Self $\mathrm{Na}$ (rra)tions: Mustafa Kemal's Nutuk and Halide Edib's Memoirs and The Turkish Ordeal." The South Atlantic Quarterly 102.2/3 (Spring/Summer 2003): 509-27. Print.

Adil, Alev. "The Forty Rules of Love: By Elif Shafak." The Independent 9 July 2010. Web. 12 August 2016. http://www.independent.co.uk/arts-entertainment/ books/reviews/the-forty-rules-of-love-by-elif-shafak-2021678.html.

Ágoston, Gábor and Bruce Masters. Encyclopedia of the Ottoman Empire. New York: Infobase, 2009. Print.

Albayrak, Aydin. "Foreing Conspiracy Discourse May also be Used before 2014 Elections." Today's Zaman 21 July 2013. Web. 27 February 2015. http://www. todayszaman.com/national_foreign-conspiracy-discourse-may-also-beused-before-2014-elections_321264.html.

Alexander, Robin. "Sultan Erdogan, der Vizekanzler." Die Welt 17 April 2016. Web. 25 July 2016. http://www.welt.de/politik/deutschland/article154432244/ Sultan-Erdogan-der-Vizekanzler.html.

Alger, William Rounseville. The Poetry of the East. Boston: Wittemore, Niles, Hall, 1856. Print.

Almond, Ian. "Islam, Melancholy, and Sad, Concrete Minarets: The Futility of Narratives in Orhan Pamuk's The Black Book." New Literary History 34.1 (Winter 2003): 75-90. Print.

Altunisik, Meliha. "The Turkish Model and Democratization in the Middle East." Arab Studies Quarterly 27.1/2 (Winter/Spring 2005): 45-63. Print.

Anderson, Benedict. Imagined Communities: Reflections on the Origin and Spread of Nationalism. New York: Verso, 2006. Print.

Anguelov, Zlatko. “Orhan Pamuk.” The Writing University, 7 January 2012. Web. 17 December 2014. http://www.writinguniversity.org/writers/orhan-pamuk.

Anon. “Critical Outtakes: Elif Shafak on Language.” Critical Mass, February 2007. Web. 19 February 2015. http://bookcritics.org/blog/archive/critical-outtakeselif-shafak-on-language.

Anon. “Erdogan: Vom religiösen Häftling zum türkischen 'Sultan"' Die Presse. Web. 25 July 2016. http://diepresse.com/home/politik/aussenpolitik/3851870/ Erdogan_Vom-religiosen-Haeftling-zum-turkischen-Sultan?gal=3851870\&i ndex $=1 \&$ direct $=\& \_$vl_backlink=\&popup $=$.

Anon. “Post-National Voices.” New Perspectives Quarterly 22.3 (Summer 2005): n.p. Print. 
Anon. "Review of Seven Houses by Alev Lytle Croutier." San Francisco Examiner 8 November 2008. Print.

Anon. "To All Hai Dat Champions and Armenian Turk Lovers." Armenian Forum, August 2004. Web. 2 February 2015. http://forum.hyeclub.com/showthread. php/4648-To-all-quot-Hai-Dat-quot-champions-and-Armenian-Turk-lovers.

Anon. "University Students Occupy Starbucks Shop." Hürriyet Daily News 8 December 2011. Web. 15 May 2015. http://www.hurriyetdailynews.com/univer sity-students-occupy-starbucks-shop.aspx?pageID $=238 \& n I D=8757 \& N e w s C$ atID=341.

Appiah, Kwame Anthony. "Cosmopolitan Patriots." Critical Inquiry 23.3 (Spring 1997): 617-639. Print.

Ashcroft, Bill. “Critical Utopias.” Textual Practice 21.3 (2007): 411-31. Print.

-. "Spaces of Utopia." Spaces of Utopia 2.1 (2012): 1-17. Print.

-. "The Ambiguous Necessity of Utopia." Social Alternatives 28.3 (2009): 8-14. Print.

-, Garreth Griffiths, and Ellen Tiffin. The Empire Writes Back: Theory and Practice in Post-Colonial Literatures. 1989. London: Routledge, 2002. Print.

Assman, Jan. Das kulturelle Gedächtnis: Schrift, Erinnerung und politische Identität in frühen Hochkulturen. Munich: Beck, 2005. Print.

Attar, Farid ud-din. The Conference of the Birds. Trans. Afham Darbandi and Dick Davis. 1117. London: Penguin, 1984. Print.

Aymes, Marc. "Many a Standard at a Time: The Ottomans' Leverage with Empire Issues." Contributions to the History of Concepts (Summer 2013). 26-43. Print.

Azoulay, Ariella. "When a Demolished House Becomes a Public Square." Imperial Debris: On Ruins and Ruination. Ed. Ann Laura Stoler. Durham: Duke UP, 2014. 194-236. Print.

Bacon, Francis. The New Atlantis. 1627. Scotts Valley: IAP, 2009. Print.

Barks, Coleman. The Essential Rumi. New York: Harper Collins, 1995. Print.

Başci, Pelin. "Shadows in the Missionary Garden of Roses: Women of Turkey in American Missionary Texts." Deconstructing Images of the Turkish Woman. Ed. Zehra Arat. New York: St. Martin's, 1998. Print.

Barth, John. Chimera. 1972. New York: Houghton Mifflin, 2001. Print.

-."The Literature of Exhaustion." The Friday Book: Essays and Other Non-Fiction. 1967. London: The John Hopkins University Press, 1984. 62-76. Print.

-. "The Literature of Replenishment." The Friday Book: Essays and Other NonFiction. 1980. London: John Hopkins UP, 1984. 193-206. Print. 
Barthes, Roland. "The Death of the Author." 1967. Web. 19 March 2013. http:// www.deathoftheauthor.com/.

Batuman, Elif. "Cover Story: The Head Scarf, Modern Turkey, and Me." The New York Times 8 February 2016. Web. 21 July 2016. http://www.newyorker.com/ magazine/2016/02/08/cover-story-personal-history-elif-batuman.

-. "Istanbul's Troubled Garden: Gezi Park's Flowers." The New Yorker 16 July 2013. Web. 30 September 2013. www.newyorker.com/online/blogs/news desk/2013/07/istanbuls-troubled-gardens-gezi-parks-flowers.html?printable $=$ true\&currentPage $=$ all.

-. "Lost in Taksim Square." The New Yorker 13 June 2013. Web. 30 September 2013. www.newyorker.com/online/blogs/newsdesk/2013/06/lost-in-taksim-square. html? printable $=$ true\&currentPage $=$ all.

-. "Occupy Gezi: Police against Protesters in Istanbul." The New Yorker 1 June 2013. Web. 30 September 2013. www.newyorker.com/online/blogs/newsdesk/2013/06/ occupy-taksim-police-against-protesters-in-istanbul.html?printable=true\&curre ntPage $=$ all.

Bauman, Zygmunt. Socialism: The Active Utopia. New York: Homes and Meier, 1976. Print.

Bhabha, Homi K. "The Commitment to Theory." New Formations 5 (Summer 1998): 5-23. Print.

Bechev, Dimiter and Calipso Nikolaidis, ed. Mediterranean Frontiers: Borders, Conflict and Memory in a Transnational World. London: Tauris, 2010. Print.

Bloch, Ernst. The Utopian Function of Art and Literature: Selected Essays. Cambridge: MIT Press, 1988. Print.

Bloom, Harold. The American Religion: The Emergence of the Post-Christian Nation. New York: Simon and Schuster, 1992. Print.

Blunt, Alice. "Collective Memory and Productive Nostalgia: Anglo-Indian Homemaking at McCluskieganj." Environment and Planning: Society and Space 21.6 (2003): 717-738. Print.

Boelhower, William and Alfred Hornung. Multiculturalism and the American Self. Heidelberg, Winter: 2000. Print.

Boym, Svetlana. The Future of Nostalgia. New York: Basic Books, 2001. Print.

Bozdoğan, Sibel. "Democracy, Development, and the Americanization of Turkish Architectural Culture in the 1950s." Modernism and the Middle East: Architecture and Politics in the Twentieth Century. Ed. Sandy Isenstadt and Kishwar Rizvi. Washington: U of Washington P, 2008. 116-138. Print.

Braidotti, Rosi. Nomadic Subjects: Embodiment and Sexual Difference in Contemporary Feminist Theory. New York: Columbia UP, 1994. Print. 
Brendemoen, Bernt. "Orhan Pamuk and his Black Book." Accurata description: Studier i kartografi, numismatik, orientalistik och bibliotekvesen tillägnade Ulla Ehrensvärd. Ed. Göran Bäärnhielm and Folke Sandgren. Stockholm: Kungliga, 2003. 41-50. Print.

Buchenau, Barbara. “The Goods of Bad Mobility: Pierre-Esprit Radisson's Relation of my Voyage, Being in Bondage in the Lands of the Irokoits, 1669/1885." English on the Move: Mobilities in Literature and Language, SPELL 27 (Swiss Papers in English Literatures and Languages). Ed. David Britain and Annette KernStähler. Tübingen: Narr, 2012.53-68. Print.

- and Virginia Richter, with Marijke Denger. Post-Empire Imaginaries? Anglophone Literature, History, and the Demise of Empire. Leiden: Brill, 2015.

Campanella, Tommaso. The City of the Sun. 1602. New York: Cosimo, 2007.

Çandar, Cengiz. "Atatürk's Ambiguous Legacy." The Wilson Quarterly 24.4 (Fall 2000): 88-96. Print.

Carruthers, Jo. "Into Connection." Third Way, 2008. Web. 4 July 2014. http://www. thirdwaymagazine.co.uk/editions/julaug-2011/high-profile/into-connection. aspx.

Cavendish, Margaret. The Blazing World and Other Writings. 1666. London: Penguin, 1994. Print.

Cerasi, Maurice. “The Formation of Ottoman House Types: A Comparative Study in Interaction with Neighboring Cultures." Mugarnas 15 (1998): 116-56. Print.

Chittick, William C. Sufism: A Short Introduction. Oxford: Oneworld, 2000. Print.

-. The Sufi Doctrine of Rumi. Bloomington: World Wisdom, 2005. Print.

Clifford, James. “Diasporas.” Cultural Anthropology 9.3 (1994): 302-338. Print.

Çolak, Yilmaz. “Ottomanism vs. Kemalism: Collective Memory and Cultural Pluralism in 1990s Turkey." Middle Eastern Studies 42.4 (2006): 587-602. Print.

Cooper, Frederick and Ann Laura Stoler. Tensions of Empire: Colonial Cultures in a Bourgeois World. Berkeley: U of California P, 1997. Print.

Criss, Nur Bilge. "A Short History of Anti-Americanism and Terrorism: The Turkish Case." The Journal of American History 89.2 (September 2002): 472-484. Print.

Croutier, Alev Lytle. Harem: The World behind the Veil. New York: Abbeville Press, 1989. Print.

-. Seven Houses. New York: Washington Square Press, 2002. Print.

-. Taking the Waters: Spirit, Art, Sensuality. New York: Abbeville Press, 1992. Print.

-. Croutier, Alev Lytle. The Palace of Tears. Peaslake: Delta, 2008. Print. 
Daği, İhsan. "What Is behind the Veil of Conspiracy Theories." Today's Zaman 16 June 2013. Web. 27 February 2013. http://www.todayszaman.com/columnist/ ihsan-dagi/what-is-behind-the-veil-of-conspiracy-theories_318426.html.

Dalrymple,William. "The Muslims in the Middle." The New York Times 10 August 2010. Web. 13 July 2016. http://www.nytimes.com/2010/08/17/opinion/17dalrymple. html?_r=0.

Damrosch, David. What Is World Literature? Princeton: Princeton UP, 2003. Print.

Delanty, Gerard. “The Emerging Field of Cosmopolitan Studies." In Routledge Handbook of Cosmopolitanism Studies. Ed. Gerard Delanty. London: Routledge, 2000. 1-8. Print.

-."The Idea of Critical Cosmopolitanism." Routledge Handbook of Cosmopolitanism Studies. Ed. Gerard Delanty. London: Routledge, 2000. 38-46. Print.

Direnç, Dilek. "Şeyh Galip: Beauty and Love." The International Fiction Review 34.1 (2007): n.p. Print.

Deringil, Selim. “They Live in a State of Nomadism and Savagery': The Late Ottoman Empire and the Post-Colonial Debate." Comparative Studies in Society and History 45.2 (April 2003): 311-342. Print.

Devrim, Shirin. A Turkish Tapestry: The Shakirs of Istanbul. London: Quartet Books, 1994. Print.

Dewey, John. "Report and Recommendation upon Turkish Education." 1939. Web. 16 August 2016. https://chipbruce.files.wordpress.com/2008/10/dewey_ turkey.pdf.

Durakbasa, Ayse, and Aynur Ilyasoglu. "Formation of Gender Identities in Republican Turkey and Women's Narratives as Transmitters of 'Herstory' of Modernization." Journal of Social History 35.1 (2001): 195-203. Print.

Edip, Halide. Memoirs of Halide Edip. New York: The Century, 1926. Print.

-. The Turkish Ordeal: Being the Further Memoirs of Halide Edip. New York: The Century, 1928. Print.

-. Turkey Faces West: A Turkish View of Recent Changes and their Origins. New Haven: Yale UP, 1930. Print.

Ekrem, Selma. Unveiled: The Autobiography of a Turkish Girl. Piscataway: Gorgias Press, 2005. Print.

El-Zein, Amira. "Spiritual Consumption in the United States: The Rumi Phenomenon." Islam and Christian-Muslim Relationships 11.1 (2000): 71-85. Print.

Elias, Jamal. Death before Dying: The Sufi Poems of Sultan Bahu. Los Angeles: U of California P, 1998. Print. 
Emerson, Ralph Waldo. Lectures and Biographical Sketches. 1884; Whitefish: Kessinger, 2004. Print.

-. "The Oversoul." 1841. Web. 19 march 2013. http://www.emersoncentral.com/ oversoul.htm.

-."Persian Poetry."1876.Web.19March 2013.http://oll.libertyfund.org/?option=com_ staticxt\&staticfile=show.php\%3Ftitle=1946\&chapter $=121136 \&$ layout=html\&Ite $\operatorname{mid}=27$.

-. “The Preacher." 1880. Web. 13 July 2016. http://www.bartleby.com/90/1008.html.

-. The Works of Ralph Waldo Emerson. 1909. Web. 21 November 2013. http://oll. libertyfund.org/?option $=$ com_staticxt\&staticfile $=$ show.php\%3Ftitle $=1960 \& \mathrm{c}$ hapter $=123058 \&$ layout $=$ html\&Itemid $=27$.

Emig, Rainer and Oliver Lindner. Commodifying (Post)Colonialism: Othering, Reification, Commodification and the New Literatures in English. Amsterdam: Rodopi, 2010. Print.

Engdahl, Horace. “A Nobel Sensibility.” World Policy Journal 27.3 (Autumn 2010): 41-45. Print.

Ertuğrul, Kürşad. "A Reading of the Turkish Novel: Three Ways of Constituting the 'Turkish Modern." Middle East Studies 41 (2009): 635-52. Print.

Ergin, Seçkin and Ahmet Beşe. "Messiahs for and against the Dominant Culture: Political Writing of American and Turkish Women in the Late $19^{\text {th }}$ and Early $20^{\text {th }}$ Centuries." Paper presented at the Annual American Studies Seminar. 14-17 November 2002. Dedeman-Antalya.

Evin, Ahmet. Origins and Development of the Turkish Novel. Beirut: Bibliotheca Islamica, 1983. Print.

Fadda-Conrey, Carol. Contemporary Arab-American Literature: Transnational Reconfigurations of Citizenship and Belonging. New York: NYU Press, 2014. Print.

Fanon, Frantz. Black Skin, White Masks. New York: Grove, 2008. Print.

Farzan, Massud. "Whitman and Sufism: Towards 'A Persian Lesson." American Literature 47.4 (January 1976): 572-82. Print.

Fayez, Ghulam. "Images of the Divine in Rumi and Whitman." Comparative Literature Studies 17.1 (March 1980): 33-43. Print.

Fisher Fishkin, Shelley. "Crossroads of Cultures: The Transnational Turn in American Studies, Presidential Address to the American Studies Association, November 12, 2004.” American Quarterly 57.1 (March 2005): 17-57. Print.

Fluck, Winfried. "Inside and Outside: What Kind of Knowledge Do We Need? A Response to the Presidential Address." American Quarterly 59.1 (March 2007): 23-32. Print. 
-, Stefan Brandt, and Ingrid Thaler. "Introduction: The Challenges of Transnational American Studies." Romance with America? Essays on Culture, Literature, and American Studies. Ed. Winfried Fluck. Heidelberg: Winter, 2009. 1-7. Print.

-, Donald Pease, and John Carlos Rowe, ed. Re-Mapping the Transnational Turn in American Studies. Darmouth: Darmouth CP, 2011. Print.

-. "The Americanization of German Culture? The Strange, Paradoxical Ways of Modernity." German Pop Culture: How "American" Is it? Ed. Agnes C. Mueller. Ann Arbor: U of Michigan P, 2004. 19-39. Print.

-. "Theories of American Culture (and the Transnational Turn in American Studies)." Romance with America? Essays on Culture, Literature, and American Studies. Ed. Winfried Fluck. Heidelberg: Winter, 2009: 59-77. Print.

Ford, Arthur L. "The Rose-Gardens of the World: Near East Imagery in the Poetry of Walt Whitman." The Walt Whitman Quarterly 5.1 (Summer 1987): 12-20. Print.

Foucault, Michel. "Of Other Spaces." Trans. Jay Miskoviec. Architecture /Mouvement/ Continuité (October 1984): 1-9. Print.

-. "The Order of Discourse." Untying the Text: A Post-Structuralist Reader. Ed. Robert Young. London: Routledge, 1981. 48-78. Print.

-. "What is an Author?" 1969. Web. 19 March 2013. https://wiki.brown.edu/con fluence/download/attachments/74858352/FoucaultWhatIsAnAuthor.pdf?ver sion $=1$ \&modificationDate $=1296272754000$.

Friedensohn, Doris. “Toward a Post-Imperial, Transnational American Studies: Notes of a Frequent Flier." American Studies International 36.1 (February 1998): 26-45. Print.

Frishkopf, Michael. "Authorship in Sufi Poetry." Alif: Journal of Comparative Poetics 23 (2003): 78-108. Print.

Furlanetto, Elena. "Imagine a Country where We Are All Equal': Imperial Nostalgia and Ottoman Utopia in Contemporary Turkish Literature." Post-Empire Imaginaries? Anglophone Literature, History, and the Demise of Empires. Ed. Virginia Richter, Barbara Buchenau, with Mareijke Denger. Leiden: Brill, 2015. 159-180. Print.

-. "Safe Spaces of the Like-Minded': The Search of a Hybrid Post-Ottoman Identity in Elif Shafak's The Bastard of Istanbul." Commonwealth Essays and Studies 36.2 (Spring 2014): 19-31. Print.

-. "The 'Rumi Phenomenon' between Orientalism and Cosmopolitanism: the Case of Elif Shafak's The Forty Rules of Love." Myths of Europe, East of Venice. Spec. issue of European Journal of English Studies. Ed. Aidan O'Malley and Stephanos Stephanides. London: Taylor and Francis, 2013. 201-213. Print. 
“Gap.” Oxford English Dictionary. Web. http://www.oed.com/view/Entry/76658?r skey=5Vr5Hb\&result=1\#eid. 16 August 2016.

Gilroy, Paul. After Empire: Multiculture or Postcolonial Melancholia. London: Routledge, 2004. Print.

-. Postcolonial Melancholia. New York: Columbia UP, 2005. Print.

Ghaussy, Sohelia. "Das Vaterland verlassen: Nomadic Language and 'Feminine Writing' in Emine Sevgi Ozdamar's Das Leben ist eine Karawanserei." The German Quarterly 72.1 (1999): 1-16. Print.

Göçek, Fatma Müge. “Where is Turkey Headed?” Daily Zaman 19 June 2013. Web. 30 September 2013. www.todayszaman.com/newsDetail_openPrintPage. action?newsId=318692.

Göknar, Erdağ. “Orhan Pamuk and the 'Ottoman’ Theme.” World Literature Today 80.6 (2006): 34-8. Print.

-. Orhan Pamuk, Secularism and Blasphemy: The Politics of the Turkish Novel. London: Routledge, 2013. Print.

-. "Ottoman Past and Turkish Future: Ambivalence in A. H. Tampinar's Those Outside the Scenes." The South Atlantic Quarterly 102.2/3 (Spring/Summer 2003): 647-661. Print.

-. "Secular Blasphemies: Orhan Pamuk and the Turkish Novel." Novel: A Forum on Fiction 45.2 (2012): 301-26. Print.

Gün, Güneli. On the Road to Baghdad. London: Picador, 1994. Print.

-. "The Turks Are Coming: Deciphering Orhan Pamuk's The Black Book." World Literature Today 66.1 (Winter 1992): 59-63. Print.

Haberman, David. People Trees: Worship of Trees in Northern India. Oxford: Oxford UP, 2013. Print.

Habermas, Jürgen. "The European Nation-State and the Pressure of Globalization." New Left Review 23.5 (1999): 46-59. Print.

Hall, Stuart. "Cultural Identity and Diaspora." Identity, Community, Culture, Difference. Ed. John Rutherford. London: Lawrence and Wishart, 1990. 222-37. Print.

Hardt, Michael and Antonio Negri. Empire. Cambridge: Harvard UP, 2000. Print. Harrington, James. The Commonwealth of Oceana and a System of Politics. 1656. Cambridge: Cambridge UP, 1992. Print.

Haught, Nancy. "A Pomegranate for All Religions: Looking at the Fruit's Spiritual Properties in Hinduism, Buddhism, Judaism, Christianity and Islam." Religion News Service. Web. 4 July 2014. http://www.beliefnet.com/News/2005/11/APomegranate-For-All-Religions.aspx?p=2\#qXiQwjZKD88Jff6T.99. 
Helvacioglu, Banu. “'Allahu Ekber', We Are Turks: Yearning for a Different Homecoming at the Periphery of Europe." Third World Quarterly 17.3 (September 1996): 503-523. Print.

Henderson, Heike. "Re-Thinking and Re-Writing Heimat: Turkish Women Writers in Germany." Women in German Yearbook 13 (1997): 225-243. Print.

Housepian, Marjorie. The Smyrna Affair. Washington DC: Library of Congress, 1966. Print.

Huggan, Graham. “The Postcolonial Exotic." Transition 64 (1994): 22-29. Print.

Inglis, David. "Alternative Histories of Cosmopolitanism: Reconfiguring Classical Legacies." Routledge Handbook of Cosmopolitanism Studies. Ed. Gerard Delanty. London: Routledge, 2000. 11-24. Print.

Jahanpour, Farhang. "Ralph Waldo Emerson and the Sufis: From Puritanism to Transcendentalism." Journal of Globalization for the Common Good. October 2007. Web. 28 February 2013. www.payvand.com/news/07/oct/1251.html.

Jamal, Mahmood. Islamic Mystical Poetry: Sufi Verse from the Early Mystics to Rumi. New York: Penguin, 2009. Print.

Köksal, Duygu. "Nationalist Theory in the Writings of Halide Edib." Turkish Studies Association Bulletin 17 (1993): 80-91. Print.

Kadir, Djelal. “Turkish Family Romance.” World Literature Today (1992): 63-65. Print.

Karpat, Kemal and Deniz Balğamiş. Turkish Migration to the United States. Madison: $\mathrm{U}$ of Wisconsin P, 2008. Print.

Kaya, Ilhan. "Identity and Space: The Case of Turkish Americans." Geographical Review 95.3 (2005): 425-440. Print.

-. Shifting Turkish American Identity Formations in the United States. Dissertation; Tallahassee Florida State University, 2003. Print.

-. "Turkish-American Immigration History and Identity Formations." Journal of Muslim Minority Affairs 24.2 (2004): 295-308. Print.

Kellner, Douglas. “Ernst Bloch, Utopia and Ideology Critique." Not Yet: Reconsidering Ernst Bloch. Ed. Jamie Owen Daniel and Tom Moylan. New York: Verso, 1997. 80-95. Print.

Knysh, Alexander. Islamic Mysticism: A Short History. Leiden: Brill, 2000. Print.

Knoke, William. Bold New World: The Essential Road Map to the Twenty-first Century. New York: Kodansha International, 1996. Print.

Koci, Mallory Katherine. Istanbul: Redefining Topoi and Establishing the City as Character in Contemporary Turkish Novels. Emporia: Emporia State University, 2009. Print. 
Komins, Benton Jay. "Cosmopolitanism Depopulated: The Cultures of Integration, Concealment, and Evacuation in Istanbul." Comparative Literature Studies 39.4 (2002): 360-385. Print.

Konuk, Kader. East West Mimesis: Auerbach in Turkey. Stanford: Stanford UP: 2010. Print.

-. Identitäten im Prozeß: Literatur von Autorinnen aus und in der Türkei in deutscher, englischer und türkischer Sprache. Essen: Die Blaue Eule, 2001. Print.

-. "Sufism and Postmodernism in Güneli Gün's On the Road to Baghdad." Wandering Selves: Essays on Migration and Multiculturalism. Ed. Michael Porsche and Christian Berkemeier. Essen: Die Blaue Eule, 2001. Print.

Kucukmehmetoğlu, Mehmet and Abdurrahman Geymen. "Urban Sprawl Factors in the Surface Water Resource Basins in Istanbul." Land Use Policy 26.3 (July 2009): 569-579. Print.

Landry, Donna. "The Ottoman Imaginary of Evliya Çelebi: From Postcolonial to Postimperial Rifts in Time." Post-Empire Imaginaries? Anglophone Literature, History, and the Demise of Empires. Ed. Barbara Buchenau, Virginia Richter, with Mareijke Denger. Leiden: Brill, 2015. 127-158. Print.

Lapidot-Firilla, Anat. "Subway Women' and the American Near East Relief in Anatolia, 1919-1924." Gendering Religion and Politics: Untangling Modernities. Ed. Hanna Herzog and Ann Braude. New York: Palgrave MacMillan, 2009. 153-172. Print.

Laschinger, Verena, ed. Turkish-American Literature. Spec. issue of Amerikasstudien/American Studies 61.2 (2016). Print.

Lau, Lisa. "Introducing Re-Orientalism: A New Manifestation of Orientalism." Re-Orientalism and South Asian Identity Politics: The Oriental Other Within. Ed. Lisa Lau and Ana Christina Mendes. London: Routledge, 2011.1-14. Print.

-. "Introducing Re-Orientalism: Theory and Discourse in Indian Writing in English." Re-Orientalism and Indian Writing in English. Ed. Lisa Lau and Om Prakash Diwedi. New York: Palgrave MacMillan, 2014. 1-26. Print.

-. "Re-Orientalism: The Perpetration and Development of Orientalism by Orientals." Modern Asian Studies 43.2 (2009): 571-590. Print.

Lechler, George. "The Tree of Life in Indo-European and Islamic Cultures." Ars Islamica 4 (1937): 369-419. Print.

Lee, Rachel C. The Americas of Asian American Literature. Princeton: Princeton UP, 1999. Print.

Leri, Alice. Who is Turkish American? Investigating Contemporary Discourses on Turkish Americanness. Dissertation. Tilburg: Tilburg University, 2014. Web. 9 July 2016. https:/pure.uvt.nl/portal/files/4022231/Leri_WhoIsTurkish_09_09_2014.pdf. 
Lerner, Daniel. The Passing of Traditional Society: Modernizing the Middle East. London: Macmillan, 1958.

Lippard, Lucy R. "Independent Identities." Photography and Soul Stealing; Native American Art in the Twentieth Century: Makers, Meanings, Histories. Ed. Jackson Rushing III. London: Routledge, 1999. 134-148. Print.

MacDonald, Alison. “A Conversation with Elif Shafak." Otium 2.1 (April 2005): n.pag. Print.

Maine, David. "Is The Forty Rules of Love a Turkish Delight? Not Exactly." Pop Matters, 11 July 2011. Web. 10 March 2013. http://www.popmatters.com/pm/ review/144524-the-forty-rules-of-love-by-elif-shafak/.

Makdisi, Ussama. “Ottoman Orientalism.” The American Historical Review 107.3 (June 2002): 768-796. Print.

Mardin, Serif. "Turkish Islamic Exceptionalism Yesterday and Today." Turkish Studies 6.2 (June 2005): 145-165. Print.

Marin, Louis. "Frontiers of Utopia: Past and Present." Critical Inquiry 19.3 (Spring 1993): 397-420. Print.

Marx, Leo. The Machine in the Garden: Technology and the Pastoral Ideal in America. Oxford: Oxford UP, 1964. Print.

Masroori, Cyrus. "An Islamic Language of Toleration: Rumi's Criticism of Religious Persecution." Political Research Quarterly 63.2 (June 2010): 243-256. Print.

May, Stephen. Language and Minority Rights. London: Routledge, 2012. Print.

Meade Earl, Edward. Preface. Turkey Faces West. By Halide Edip. New Haven: Yale UP, 1930. ix-ivx. Print.

Mignolo, David. "De-Colonial Cosmopolitanism and Dialogues among Civilizations." Routledge Handbook of Cosmopolitanism Studies. Ed. Gerard Delanty. London: Routledge, 2000. 85-100. Print.

Mikhail, Alan and Christine M. Philliou. "The Ottoman Empire and the Imperial Turn." Comparative Studies in Society and History 54.4 (October 2012): 721-745. Print.

Mills, Amy. "Narratives in City Landscapes: Cultural Identity in Istanbul." Geographical Review 95.3 (July 2005): 441-462. Print.

-. "The Place of Locality for Identity in the Nation: Minority Narratives of Cosmopolitan Istanbul." Middle Eastern Studies 40 (2008): 383-401. Print.

More, Thomas. Utopia. 1516; Oxford: Oxford UP, 1998. Print.

Moretti, Franco. “Conjectures on World Literature." New Left Review 1 (January/ February 2000): 54-68. Print. 
Moth, Laura. "Fear of Foreign Agents in Gezi." Daily Zaman 16 June 2013. Web. 25 July 2013. www.todayszaman.com/newsDetail_openPrintPage.action?newsId=318392.

Mouradian, Khatchig. "An Interview with Fatma Muge Göçek." Head over Hat, June 2007. Web. 18 November 2014. http://headoverhat.blogspot.de/2007/06/ interview-with-muge-gocek.html.

Mufti, Malik. "A Little America: The Emergence of Turkish Hegemony." Middle East Brief 51 (May 2011): 1-8. Print.

Mutman, Mahmut. "The Nation-Form." Third Text 22.1 (2008): 5-20. Print.

Nasr, Seyyed Hossein. Sufi Essays. Albany: State U of New York P. 1991. Print.

Ngugi, Wa Thiong'o. Decolonising the Mind: The Politics of Language in African Literature. Nairobi: East African Publishers, 1994. Print.

Oliver, Charles M. Critical Companion to Walt Whitman: A Literary Reference to his Life and Work. New York: Facts on File, 2006. Print.

Pamuk, Orhan. Cevdet Bey ve Oğulları. 1982. Istanbul: İletişim Yayınları, 2003. Print.

-. Istanbul: Memories and the City. Trans. Maureen Freely. New York: Random House, 2006. Print.

-. "My Father's Suitcase." Nobelprize.org, 7 December 2006. Web. 17 December 2014. http://www.nobelprize.org/nobel_prizes/literature/laureates/2006/pamuk-lec ture_en.html.

-. My Name is Red. Trans. Erdağ Göknar. 1998. New York: Random House, 2001. Print.

-. Other Colors. Translation Maureen Freely. 1999. New York: Random House, 2007. Print.

-. The Silent House. Trans. Maureen Freely. 1983. New York: Random House, 2012. Print.

-. Snow. Trans. Maureen Freely. 2002. New York: Random House, 2004. Print.

-. The Black Book. Trans. Maureen Freely. 1990. London: Faber and Faber, 2011. Print.

-. The Museum of Innocence. Trans. Maureen Freely. 2008. New York: Random House: 2009. Print.

-. The Naïve and the Sentimental Novelist. Cambridge: Harvard UP, 2011. Print.

-. The New Life. Trans. Güneli Gün. 1994. London: Faber and Faber, 1998. Print.

-. The White Castle. Trans. Vitoria Holbrook. 1985. London: Vintage, 1998. Print.

Parla, Jale. "The Object of Comparison." Comparative Literature Studies 41.1 (2004): 116-125. Print. 
"Pit." Oxford English Dictionary. Web. http://www.oed.com/view/Entry/144669?r skey=A1sRCz\&result=1\&isAdvanced=false\#eid. 16 August 2016.

Preminger, Otto, dir. Forever Amber. $20^{\text {th }}$ Century Fox, 1947. Film.

Pultar, Gönül. "Güneli Gün's On the Road to Baghdad: Travelling Biculturalism." On the Road to Baghdad: Or, Travelling Biculturalism. Ed. Gönül Pültar. Washington: New Academia, 2005. 47-64. Print.

- "Ethnic Fatigue: Başçıllar's Poetry as a Metaphor for the Other 'Other Literature." in Multilingual America: Transnationalism, Ethnicity, and the Languages of American Literature. Ed. Werner Sollors. New York: NYU Press, 1998. 124-143. Print.

Ramsey-Kurz, Helga and Geetha Ganapathy-Doré. Projections of Paradise: Ideal Elsewheres in Postcolonial Migrant Literature. Amsterdam: Rodopi, 2011. Print.

Raw, Laurence. "Communicating America, Validating Turkey." Journal of American Studies of Turkey 10 (1999): 81-89. Print.

Rich, Wilbur C. The Post-racial Society is Here: Recognition, Critics and the Nationstate. London: Routledge, 2013. Print.

Ricoeur, Paul. Lectures on Ideology and Utopia. New York: Columbia University Press, 1986. Print.

Rishmawi, George K. "Emerson and the Sufis." The Muslim World 85.1-2 (January 1995): 147-155. Print.

Rosen, Judith. "Alev Lytle Croutier: The Palace of Tears." Publishers Weekly 7 August 2000: 63. Print.

Rowe, John Carlos, ed. Post-Nationalist American Studies. Berkeley: U of California P, 2000. Print.

Rumi, Jalal Al-Din. The Masnavi: Book One. Trans. Jawid Mojaddedi. Oxford: Oxford UP, 2004. Print.

Said, Edward W. "My Right of Return." Power, Politics, and Culture: Interviews with Edward W. Said. Ed. Gauri Viswanathan. 2001. London: Bloomsbury, 2005. Print.

-. Orientalism. 1978. New York: Vintage Books, 1979. Print.

Salt, Jeremy. “Trouble Wherever They Went: American Missionaries in Anatolia and Ottoman Syria in the Nineteenth Century." The Muslim World 92 (2002): 286-313. Print.

Schein, Louisa. "Gender and Internal Orientalism in China." Modern China 23.1 (1997): 69-98. Print.

Schimmel, Annemarie. Mystical Dimensions of Islam. Chapel Hill: U of North Carolina P, 1975. Print.

-. As Through a Veil: Mystical Poetry in Islam. New York: Columbia UP, 1982. 
Sedlmeier, Florian. The Postethnic Literary: Reading Paratexts and Transpositions around 2000. Berlin: De Gruyter, 2014. Print.

Shafak, Elif. Black Milk. New York: Penguin, 2007. Print.

- (interview with). "Critical Outtakes: Elif Shafak on Language." Critical Mass 24 February 2007. Web. 25 July 2016. http://bookcritics.org/blog/archive/criticalouttakes-elif-shafak-on-language.

-. "Europeanization and its Enemies" Turkish Daily News 25 December 2005. Web. 28 July 2014. http://www.elifsafak.us/yazilar.asp?islem=yazi\&id=371.

-. “Fleeing Beirut.” Turkish Daily News 23 July 2006. Web. 28 July 2014. http:// www.elifsafak.us/yazilar.asp?islem=yazi\&id $=400$.

-. Honour. 2013. New York: Penguin, 2015. Print.

-. "Life in the Islands" Turkish Daily News 27 August 2006. Web. 16 May 2015. http://www.elifsafak.us/yazilar.asp?islem=yazi\&id=416.

-. (interview with). "Linguistic Cleansing." New Perspectives Quarterly 22.3 (Summer 2005): n.pag. Print.

-. "Making Sense of Irrationality: Nationalism in Turkey and its Opposite." Turkish Daily News April 2006. Web. 16 May 2014. http://www.elifsafak.us/yazilar. asp?islem $=$ yazi\&id $=388$.

-. “Memorizing." Turkish Daily News November 2006. Web. 4 July 2014. http://www.elifsafak.us/yazilar.asp?islem=yazi\&id=460.

-. "Memory-Less Turkey/Amnesiac Turkey." Turkish Daily News May 2006. Web. 16 May 2016. http://www.elifsafak.us/yazilar.asp?islem=yazi\&id=392.

- (interview with). "Migrations: A Meridians Interview with Elif Shafak." Meridians 4.1 (2003): 55-85. Print.

-. "Once the Sick Man, Now the Chimera of Europe." Turkish Daily News January 2006.Web.16 May 2015.http://www.elifsafak.us/yazilar.asp?islem=yazi\&id=372.

-. "Peddlers of Clash of Civilization." Turkish Daily News March 2006. Web. 16 May 2015. http://www.elifsafak.us/yazilar.asp?islem=yazi\&id=383.

-. Pinhan. 1997. Istanbul: Dogan Kitap, 2013. Print.

-. "Pulled by two Tides." Turkish Daily News 30 April 2006. Web. 28 July 2014. http://www.elifsafak.us/yazilar.asp?islem=yazi\&id $=408$.

-. "Safe Spaces of the Like-Minded.” Turkish Daily News November 2006. Web. 6 May 2015. http://www.elifsafak.us/yazilar.asp?islem=yazi\&id=453.

- "So Called Citizens of Turkey." Turkish Daily News 4 December 2005. Web. 28 July 2014. http://www.elifsafak.us/yazilar.asp?islem=yazi\&id=368.

-. The Architect's Apprentice. New York: Penguin, 2015. Print.

-. The Bastard of Istanbul. New York: Penguin, 2007. Print. 
-. The Flea Palace. Trans. Fatma Muge Göçek. 2002. New York: Penguin, 2012. Print.

-. The Forty Rules of Love. New York: Penguin, 2010. Print.

-. "The Gathering Place of the Djinni." Turkish Daily News 20 February 2005. Web. 17 December 2014. http://www.powerofculture.nl/en/current/2005/feb ruary/elif_shafak.html.

-. The Gaze. Trans. Fatma Muge Göcek. 2000. New York: Penguin, 2012.

-. "The Religion of Love." Turkish Daily News 17 December 2006. Web. 9 July 2016. http://www.elifsafak.us/yazilar.asp?islem=yazi\&id=478.

-. "The Return of the Ghetto: Coming Soon to a Country Near You." Turkish Daily News 13 January 2007. Web. 28 July 2014. http://www.elifsafak.us/yazilar. asp?islem $=$ yazi\&id $=497$.

-. The Saint of Incipient Insanities. New York: Penguin, 2004. Print.

-. "The Sufi Way." Hürriyet Daily News 9 November 2005. Web. 28 January 2015. http://www.hurriyetdailynews.com/default.aspx?pageid=438\&n=the-sufiway-2005-09-11.

-. "The Two Contradictory Features of Turkish Society." Turkish Daily News June 2006.Web.16 May 2015.http://www.elifsafak.us/yazilar.asp?islem=yazi\&id=396.

-. "When the Nation is Afraid of Having a Memory." Turkish Daily News March 2006. Web.4 July 2014.http://www.elifsafak.us/yazilar.asp?islem=yazi\&id=381.

-. "Women Writers, Islam, and the Ghost of Zulaikha." Web. 28 July 2014. http:// wordswithoutborders.org/article/women-writers-islam-and-the-ghost-ofzulaikha.

Shoat, Ella. "Notes on the 'Post-colonial"' Social Text 32/33 (1992): 99-113. Print.

Sollors, Werner, ed. Multilingual America: Transnationalism, Ethnicity, and the Languages of American Literature. New York: NYU Press, 1998. Print.

Sönmez, Emel. “The Novelist Halide Edib Adivar and Turkish Feminism.” Die Welt des Islams 14.1/4 (1973): 81-115. Print.

Soysal, Yasemin Nuhoğlu. Limits of Citizenship. Migrants and Postnational Membership in Europe. Chicago: U of Chicago P, 1994. Print.

Stoler, Ann Laura. Imperial Debris: On Ruins and Ruination. Durham: Duke UP, 2013. Print.

Taspinar, Ömer. "The Rise of Turkish Gaullism: Getting Turkish-American Relationships Right." Insight Turkey 13.11 (2011): 11-17. Print.

-. "The Three Strategic Visions of Turkey." US-Europe Analysis Series 50 (8 March 2011): 1-5. Web. 25 July 2016. http://www.brookings.edu/research/ papers/2011/03/08-turkey-taspinar. 
-. “Turkey's Middle East Policies: Between Neo-Ottomanism and Kemalism." Carnegie Papers 10 (September 2008). Web. 9 July 2016. http://carnegieendowment. org/files/cmec10_taspinar_final.pdf.

Thoreau, Henry David. Walden; Or, Life in the Woods. 1854. University Park: Pennsylvania State University Press, 2006. Print.

Tiffin, Helen and Graham Huggan. Postcolonial Ecocriticism: Literature, Animals, Environment. London: Routledge, 2009. Print.

Tompkins, Ptolemy. “Rumi Rules!” Time 29 October 2002. Web. 14 July 2016. http:// www.time.com/time/magazine/article/0,9171,356133,00.html.

Trinh, Minh-ha. Woman, Native, Other: Writing Postcoloniality and Feminism. Bloomington: Indiana UP, 1989. Print.

Unher, Mike and Sara Bano. "Reconciling Religion: Bulleh Shah, Ralph Waldo Emerson and the American Transcendentalist Tradition." Annual Report Faculty of Education 69 (February 2010): 1-21. Print.

Urry, John. Mobilities. Cambridge UK: Polity Press, 2007. Print.

Updike, John. "Vagueness on Wheels, Dust on a Skirt." The New Yorker 2 September 1991. 102-105. Print.

Verotta, Luisella, Maria Pia Macchi, and Padma Venkatasubramanian, ed. Connecting Indian Wisdom and Western Science: Plant Usage for Nutrition and Health. New York: CRC Press, 2015. Print.

Völtz, Johannes. "Utopias of Transnationalism and the Neoliberal State." Re-Mapping the Transnational Turn in American Studies. Ed. Winfried Fluck, Donald Pease, and John Carlos Rowe. Darmouth: Darmouth CP, 2011.356-373. Print.

Wajahat, Ali. "Professor Seyyed Hossain Nasr: Islam's Spiritual Science." Patheos 11 June 2008. Web. 24 January 2013. http://www.patheos.com/blogs/altmus lim/2008/06/islams_spiritual_science/.

Walkowitz, Rebecca. Immigrant Fictions: Contemporary Literature in an Age of Globalization. Madison: U of Wisconsin P, 2010. Print.

-. "The Location of Literature: The Transnational Book and the Migrant Writer." Contemporary Literature 47.4 (2006): 527-545. Print.

Whitman, Walt. Leaves of Grass: The Deathbed Edition. Marston Gate: Amazon, 1892. Print.

Wigen, Einar. “Turkish Neo-Ottomanism: A Turn to the Middle-East?” NUPI Security Policy Library Report (2009): 1-23. Print.

Willner, Anja. "Recep Tayyip Erdogan: So wurde er zum türkischen Sultan." Focus 14 April 2016. Web. 25 July 2016. http://www.focus.de/politik/ausland/ selbstherrlich-islamistisch-machthungrig-so-wurde-erdogan-vom-armenjungen-aus-anatolien-zum-tuerkischen-sultan_id_5435034.html. 
Winson, Kathleen. Forever Amber. Chicago: Chicago Review Press, 2000. Print.

Yanık, Lerna K. “Constructing Turkish 'Exceptionalism': Discourses of Liminality and Hybridity in Post-Cold War Turkish Foreign Policy." Political Geography 30.2 (2011): 80-89. Print.

-. “Turkish Exceptionalism and its Critics." Global Brief. 24 March 2014. Web. 21 November 2014. http://globalbrief.ca/blog/2014/03/24/turkish-exceptionalism-and-its-critics/.

Yaziji-Oglu. "The Book of Mohammed: The Creation of Paradise." Medieval Sourcebook: The Legends and Poetry of the Turks, Selections. Web. 23 May 2016. http://legacy.fordham.edu/halsall/source/turkishpoetry1.asp.

Yeğenoğlu, Meyda. "Cosmopolitanism and Migrancy." Routledge Handbook of Cosmopolitanism Studies. Ed. Gerard Delanty. London: Routledge, 2000. 414-424. Print.

Yeghenian, Aghavnie. “The Turkish Jeanne D'Arc: An Armenian Picture of Remarkable Halide Edib Hanoum.” The New York Times 11 September 1922: n.pag. Print.

Yilmaz, Şuhnaz. "Challenging the Stereotypes: Turkish-American Relations in the Inter-war Era." Middle Eastern Studies 42.2 (2006): 223-237. Print.

Young, Robert. "Postcolonial Remains." New Literary History 43.1 (Winter 2012): 19-42. Print.

Zeidanlıoglu, Welat. “'The White Turkish Man's Burden': Orientalism, Kemalism and the Kurds in Turkey." Neo-Colonial Mentalities in Contemporary Europe? Language and Discourse in the Construction of Identities. Ed. Guido Rings and Anne Ife. Newcastle upon Tyne: Cambridge Scholars, 2008. 155-174. Print. 



\section{Acknowledgements}

This book, this research, this enterprise as a whole would not have been possible without my parents, who, during a hard period of their life have offered unfailing and selfless support for dreams that others in their position would have dismissed as frivolous. I would also like to thank Elisa and Franca, who also never failed to support me and made sure I never ran out of high-quality Italian coffee | Questo libro, queste ricerche, questa impresa nel suo complesso non sarebbero state possibili senza i miei genitori, che in un periodo arduo delle loro vite hanno offerto il loro costante e disinteressato sostegno a sogni che altri, nella loro posizione, avrebbero ritenuto frivoli. Voglio anche ringraziare Elisa e Franca, che mi hanno sempre sostenuto e hanno fatto in modo di non farmi mai mancare niente, soprattutto il caffè italiano.

I am infinitely grateful to everyone who saw something in me and gave me a chance - a most wonderful and rare gesture. In primis, my Ph.D supervisor Prof. Dr. Walter Grünzweig and my second reader and postdoctoral mentor Prof. Dr. Barbara Buchenau. But also Andy Jones, who gave me my first job in Germany: a small step towards adulthood in this country.

I am grateful to my colleagues at the Technische Universität Dortmund and, later, at the University of Duisburg-Essen for sharing their invaluable inputs over and over and over again. Their thoughts are woven in the texture of my book. Those who took the time to read and patiently comment entire chapters deserve a special mention: Thank you Dietmar, Georg, and Mario. I owe much to the anonymous reviewers who helped me put my material in shape for publication, I have learned a lot from you. Thank you Barbara, Courtney, Dietmar, and Zohra, for having taken such good care of me, you are my academic family. I look forward to many years of inspiring conversations and shared projects. 
